

\section{Digitized by the Internet Archive in 2007 with funding from Microsoft Corporation}


swie 



\section{JURISPRUDENCE AND PHILOSOPHY OF}

LAW SERIES

I. Korkunov's Theory of Law

Translated by Hastings. $\$ 3.50$

II. Gareis's Science of Law

Translated by Kocourek. $\$ 3.50$ 


\title{
Introduction to the Science
}

\section{of Law}

\author{
SYSTEMATIC SURVEY \\ OF THE LAW AND PRINCIPLES OF \\ LEGAL STUDY
}

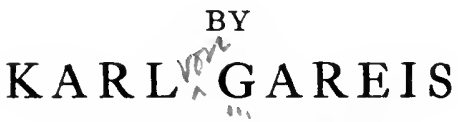

Professor of Law at Munich

TRANSLATED FROM THE THIRD, REVISED EDITION OF THE GERMAN BY

\section{ALBERT KOCOUREK}

Lecturer on Jurisprudence in Northwestern University

$$
\begin{aligned}
& \text { WITH AN INTRODUCTION BY } \\
& \text { ROSCOE POUND }
\end{aligned}
$$

Story Professor of Law in Harvard University

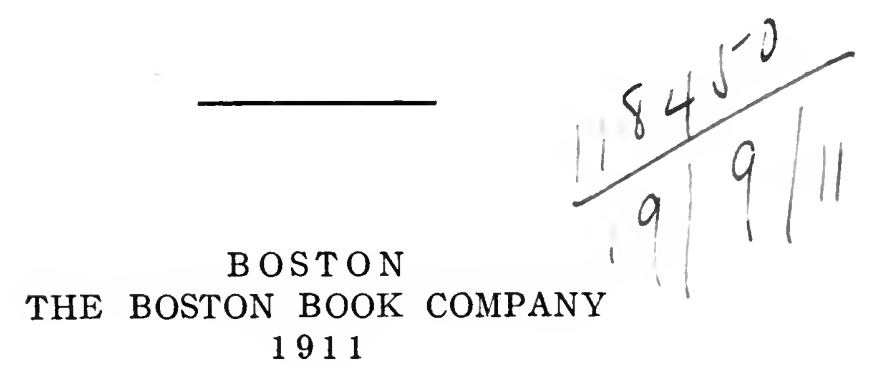


COPYRIGHT, 1911

BY THE BOSTON BOOK COMPANY

The Riverdale Press, Brookline, Mass., U.S.A. 


\title{
INTRODUCTION
}

\author{
BY ROSCOE POUND
}

Speaking broadly, we may arrange jurists in three groups or schools: philosophical, historical and analytical. To the philosophical jurist, law is the expression of an idea. It is an expression of right and justice, found rather than made by legislator or judge or text-writer. Or, as the Neo-Hegelians put it, it is the expression of the culture of a people in the form of principles for the government of men's external relations to one annther. To the historical jurist also law is found not made; but in his view something different is found. To him a principle of human action has been found by human experience and is developed as a rule of law. To the analytical jurist, on the other hand, law, at least in its matured form and in developed communities, is the product of conscious and determinate human will. The lines between these schools, however, are by no means as sharp as formerly. In England, the analytical and historical schools have been tending to a common ground. In Germany the philosophical and historical schools have been approaching each other. This approach of schools formerly at sword's points has taken place through the development of comparative jurisprudence by both schools, through the abandonment by the philosophical school of the quest for a metaphysical science of absolute legal principles, and substitution of an endeavor, 
as Berolzheimer puts it, "to deduce and fix the element of the just in and out of the positive law," and through the giving over by the historical school of the view of their founder that the Roman lawyers of the third century had such a monopoly of legal genius that modern peoples could do no more than develop Roman principles by experience of life and of litigation. Along with these movements, the rise and progress of that view of the political and social sciences which bears the awkward name of sociology has had an influence upon juristic thought the results of which, for the most part, are yet to come. It is hardly too much to say, using the term as we use it, that today there are in Germany sociological jurists of philosophical, historical or analytical tendencies, rather than jurists exclusively philosophical, historical or analytical.

In England and America we have as yet no sociological jurisprudence and no modern philosophical jurisprudence. The ground is divided between the analytical and historical schools, the balance inclining toward the former in England, where the supremacy of Parliament gives manifest verity to the analytical view of law in the every-day experience of lawyers, the latter in America, where the judicial power with respect to legislation makes such a view difficult, if not impossible. England has no philosophical juristic literature at all, unless it be the utilitarian natural-law of Austin's lectures II, III and IV, and the modified Hegelianism of T. H. Green's "Principles of Political Obligation." In America we have not a little eighteenth-century natural law in elementary books founded upon Blackstone. Otherwise, there is only the narve natural law of the practitioner, who thinks of an ideal development of the principles of the common law as the legal order of the universe, or the natural law of the historical jurist, who 
has been convicted more than once of what Bergbohm calls "anonymous natural law"; i.e., a notion-subconscious it may be-that the principles he discovers through historical research have necessary and absolute validity so that the law may develop, but cannot reject or dispense with them. Anglo-Americans gave one more proof of the instinctive sound sense which is a race characteristic, when they refused to have anything to do with the metaphysical jurisprudence of the nineteenth century which professed to set up a science of law by deduction from a few first principles. Perhaps they show an obstinate conservatism which is no less characteristic of their legal thought when they continue to identify all philosophical method in legal science with the universally discredited Naturrecht. Certainly there is good warrant for believing that lack of philosophical method in our legal science is more than merely coincident with our want of a sociological jurisprudence. Without a philosophy of law, the historical and analytical methods will not lead thereto.

The ground sought to be covered in English by the text-book on jurisprudence, which is primarily analytical, but usually endeavors to make concessions to the historical school, is occupied in Germany by three types of book: treatises on the philosophy of law, of which a notable one by the greatest living exponent of the subject appeared last year (Kohler, Lehrbuch der Rechtsphilosophie, 1909), juristic surveys (Enzyklopädie), and text-books of the general theory of law (allgemeine Rechtslehre). The first take up the philosophical foundations of the legal order, legal systems, institutions and doctrines, and the philosophical and ethical bases of particular branches of the law. The second aim rather at a systematic review of the law as a whole, employing all three of the methods of jurisprudence, but chiefly 
the philosophical and the historical. The third treat of the conception of law and the leading general conceptions of a legal system chiefly from the analytical standpoint, but not neglecting the other two. Application of the analytical method to the details of the legal system is left to the general part of treatises on the Pandects or treatises upon the Civil Law. An excellent example of the third type of book is Sternberg's Allgemeine Rechtslehre (1904). One of the best of the class, although not German, has been made available in English through Judge Hastings's translation of Korkunov's "General Theory of Law." Some of the better examples of the first are likely to be put into English soon through the initiative of the Association of American Law Schools. The present volume is representative of the second type.

Books of both the first and second of the types characterized above are not unlikely to be received with indifference, if not with suspicion, in America because of the extravagant claims formerly made for the methods respectively employed and the failure of misdirected efforts to make them do the whole work of legal science. The character of works of these types has changed entirely in the past twenty-five years, and the grounds of our formerly well founded indifference no longer exist. Today, American scholars cannot afford to neglect any form of Continental juristic writing. For one thing, we must give up the purely political interpretation of law and of legal history which has governed our treatises on jurisprudence. The political interpretation of history, which has dominated our political thought so largely, and until recently was in high favor in England and America,-an interpretation which found the clew to progress in a gradual but definite movement from absolutism to freedom in political institutions, - has its counterpart in our science of law. It is assumed that a 
movement from subjection to freedom, from status to contract, is the key to legal as well as to social development. Accordingly, it is conceived that the end of all law is liberty, and jurisprudence is assumed to be the science of civil liberty. The consequences of such views put in practice in the decisions upon liberty of contract, and judicial pronouncements upon modern social legislation, make it clear that juristic theories are not mere academic toys, but may be forces of grave moment of which legislator and social reformer must needs take account. At most, the political interpretation can be but part of the truth. The idealistic, the biological or ethnological, and the economic interpretations are not to be ignored.

It may be admitted that a systematic survey of the materials of jurisprudence might easily fail because of over-abstractness. But recent German texts err, if at all, in the opposite direction. At every point the text is fastened firmly to the German civil code. Thus the work is made concrete and is thoroughly in touch with the actual law. For us, to whom many of the conceptions of German law are thoroughly foreign, there is some disadvantage in this mode of treatment. The reader must make applications to our own legal system for himself. On the other hand, a view of the philosophical, historical and economic foundations of the greatest system of substantive law in the modern world is a compensation.

The present work is by no means a Hegelian "encyclopædia." Yet the connection of books of the type to which it belongs with the idea of "encyclopædia" is not at all unhappy. From his conception of the universe as a development of absolute thought, Hegel reasoned that each science was to be studied in connection with science as a whole, since it was but a phase of the develop- 
ment of unified science. An age of ultra-specialization made this impossible, even if Hegel's system had survived. But, apart from the philosophical foundation on which it rested originally, there is more than a fragment of truth, or, what is perhaps the same thing, there is a large fragment of utility in the notion. A reaction from excessive specialization is at hand. The future will demand not merely that legal science be unified, but that it be unified with the social sciences of which it is by no means the least. A timely assertion of the unity of the social sciences is the theme of Professor Small's recent book, "The Meaning of Social Science." One sentence is worth quoting in the present connection:-

"Sociologists declare that the experience bounded by the reactions between men and physical nature on the one hand, and the reactions of men with one another on the other, is an interconnected experience, and that we shall have a science of it only in the proportion of our insight into the way and degree in which each item of this experience is affected by every other item of it."

When at the instance and chiefly through the exertions of Professor Wigmore the Association of American Law Schools put forth the collection of Select Essays in Anglo-American Legal History, many asked doubtingly, Who is going to read them? The event has shown that judges and practitioners, as well as those who concern themselves immediately with the scholarly aspects of legal study, were prepared to do so: Too long they had been constrained to draw upon the repositories of traditional misinformation, which alone were readily available. One has but to look about him in current legal literature, and to observe how much use (or misuse) has been made and is making of Hastie's translation of extracts from a bygone German legal-philosophical literature, to perceive a similar need in legal science and 
philosophy of law. On the analytical side, indeed, we are well equipped in English. On the philosophical and historical sides and for the unification with the other social sciences which the sociological movement is demanding, as in all departments of learning, we have to look to the "inevitable German." The AngloAmerican is averse to reading in any tongue but his own. As he refuses to go to the Germans, any one who brings the twentieth-century Germans to him does jurisprudence a service.

Perhaps it should be said, in conclusion, that the present work, written for study in connection with lectures, and the copious apparatus furnished in the notes, is a book to think through, not merely to read through. 



\section{TRANSLATOR'S PREFACE}

The study of law as a social instrument and as an organism of definite related parts cannot much longer be profitably deferred in this country. The practical reasons upon which this statement may be predicated are amply stated in a symposium of views of eminent lawyers, judges and educators, recently published in connection with a proposal for private codification of our scattered and unwieldy legal system. ${ }^{1}$

Within the last forty years an important change has taken place in our methods of legal education. The school, with its systematic courses of instruction, has superseded the lawyer's office for the purposes of legal training. The theatre of action has shifted, but the repertoire remains substantially the same. This was to be expected. Evolutionary degrees are not usually attained per saltum, and an adherence to practical methods has justified the value of academic legal education.

It is generally characteristic of the specialist to claim too much for his specialty. It has been difficult for the learned investigator of Roman law to understand how any juridical progress could be made of lasting value without a study of the Mediterannean archetype. The marvelous phenomenon of Roman legal genius which has outlived the dissolving influence of two thousand years in which the material appanages of imperial splendor have returned to elemental chaos, carries its own warrant for any over-emphasized enthusiasm for this elegant and symmetrical system, and grants its own

1 Green Bag, Feb., 1910. 
indulgence for any over-balanced claim of immediate utility. ${ }^{1}$

This juristic specialist, like the civilian, has been inclined to magnify the importance of his related department, and he has been unable to understand that the administration of justice may proceed in an orderly and useful way without conscious recognition of the internal organization of the law which makes justice orderly and useful.

The law school constantly has had to defend itself against a deep-seated and wide-spread belief that the training which it affords lacks the vital element of value in practical application. Had the law school from the start placed a large emphasis on Roman law, on mediæval legal history, comparative law, and similar departments of legal science, this feeling of tolerant criticism might have become intensified into an outspoken hostility; and probably this institution would not have attained in one generation an official and predominant position in legal education.

The specialists in foundation studies have simply made the mistake of ignoring surrounding circumstances; but conditions are now rapidly shaping themselves when an intimate acquaintance with their labors will be regarded not merely as an elegant addition to a professional training, but as indispensable knowledge. This knowledge will be especially necessary in dealing in a permanent way with the stupendous accumulation of judicial detritus which threatens our entire legal system with a menace not to be underestimated. This

\footnotetext{
1Mr. Allen Upward (The New Word, 1910) says "the whole theory of our education still is that the young Englishman should make-believe to be an ancient Roman. The king who still writes himself on his coins Britannorum Rex is doing homage on his crown to Pope and Cæsar." If Mr. Upward could have understood to what extent the form of the law is indebted to the profound juristic labors of the Romans his attack on the tyranny of the past might have been softened.
} 
menace, however, is only superficial. The malady will generate its own remedy. The real danger lies in the possibility of an undigested effort ${ }^{1}$ to correct known evils by methods which may have the effect of rendering intolerable conditions that can still with increasing difficulty be endured. ${ }^{2}$

The many years of effort devoted by the Germans in the formulation of a civil code should point its own truth. ${ }^{3}$ This truth will stand out in greater relief when it is remembered that the labor of making a code in Germany had behind it a background of Roman law which itself furnished the scientific groundwork necessary for this great undertaking. ${ }^{4}$ In this country neither Roman law nor its complement, Juristic Survey, has received more than the slightest attention. Thelaw schools, which must be looked to for initiative in these matters, have so far failed to recognize the importance of these studies in their relation to our system of law;

\footnotetext{
${ }^{1}$ Professor Pound (Illinois Law Rev. Vol. IV, p. 388, et seq.) points out the dangers of reforms too hastily accomplished in connection with the law of procedure; which subject has engaged professional attention to the exclusion of the difficulties presented by the form of our law.

Professor Wigmore has announced (Green Bag, July, 1910,) his opposition to the programme for codification referred to in note 1 (p. xi.) supra, on the ground, among other reasons stated, that this country has not yet developed the special learning adequate to such an undertaking.

${ }^{2}$ Legal conditions in Germany prior to the adoption of the Civil Code were hardly less onerous than the situation presented by our overwhelming caselaw and our diversity of jurisdictions. The German Empire was divided up into six different juridical divisions governed by laws written in German, French, Latin. and even Greek. Each division also had its own local law and local custom.

Professor Henry Schofield has shown how an opportunity for a uniformity of decision as between state and federal courts has been neglected by our federal Supreme Court (Illinois Law Rev. Vol. IV, No. 8, p. 533, March, 1910).

3 The preparation of the German Civil Code commenced in 1874, and after practically continuous work on the part of learned commissions was enacted as law in 1896, and became effective Jan. 1, 1900.
}

4 Roman law received a practical position in Germany in 1495 . See Brunner, Geschichte und Quellen des Deutschen Rechts in Holtz. Enz., 4th ed., p. 267.

The form of the German Civil Code is based on the arrangement of the Pandektenlehrbücher or treatises on modern Roman La w. 
and the available literature in our language has not furthered to any appreciable extent a consciousness of this importance.

To say nothing of what may reasonably be expected of private codification, under any auspices, what success can be hoped for in any attempt (if such an attempt should unfortunately be made) to erect a ponderous legal structure upon a juristic foundation about which nothing is known, and what symmetry of form can be expected in a framed-to-order system of law where juristic architecture has never been the subject of scientific investigation? Before any legal harvest can be reaped juristic ground must be broken. ${ }^{1}$

It is the purpose of this translation to make available one more important contribution to legal science from a rich storehouse too little drawn upon. ${ }^{2}$ The Juristic Survey of Dr. Gareis is one of the most serviceable, and one of the best known on the European continent, of this class of works; and this is the first complete translation that has up to this time been made of such a work. There have been translations of metaphysical material, of Naturrecht treatises, of institutes of Roman law, of Germanized Roman law, and theory of law, but nothing heretofore has been presented corresponding with works

\footnotetext{
1 Our neglect of the study of law in its abstract, formal and philosophic aspect can be but little more reproached than the indifference of the French to this subject. See Boistel, Cours de Philosophie du Droit (prefare), Paris, 1899; Vareilles-Sommières, Les Principes Fondamentaux $d u$ Droit (preface), Paris, 1889; Lioy, Philosophie du Droit (preface of MM. Durand and Terrel). 1887 (this work has also been translated into English); Courcelle-Seneuil Préparation à l'étude du droit (preface), Paris, 1888; and Béchaux, Le Droit et les Faits Economiques (intro.), Paris, 1889. The French have recently placed one excellent work to their credit-Tourtoulon, Les Principes philoso. phiques de L'Histoire du Droit, Tome Premier, Paris, 1908.

${ }^{2} \mathrm{Mr}$. Shelden Amos (Systematic View of the Science of Jurisprudence) says, "the prospects of the science of jurisprudence, especially in England, will depend largely upon a greater familiarity than has hitherto been encouraged in legal education with the vast and invaluable juridical literature of Germany:"
} 
in our language dealing with a general survey of law in its formal aspect. ${ }^{1}$

Every doubt, hope, reservation, condition, allowance and explanation relied upon by translators and common to translations of this kind, might well be adopted here. No effort has been made (and it is hoped that this may be found to be the principal defect of this labor) to attain a mere rhetorical elegance. The obvious peril of saying more or less than the author intended has thus been avoided (or at least attempted) at the possible expense of literary refinement. The terminology created by Dr. Schuster (The Principles of German Civil Law) and followed by Dr. Chung Hui Wang (German Civil Code) has been adopted in all possible cases. Free use has been made of numerous other sources of information unnecessary of enumeration. The translator has had the exceptional advantage of being able to draw freely on the monumental learning of Dr. John H. Wigmore, Dean of Northwestern University School of Law, and Dr. Roscoe Pound, Professor of Law, Harvard University School of Law, and he acknowledges his great indebtedness to them for many profitable suggestions and much valuable enlightenment. Whatever errors may appear will be attributed and attributable solely to the translator. Thanks are tendered to Professor Wesley N. Hohfeld of Leland Stanford University for his co-operation and critical observations, and to Dr. Amos S. Hershey of Indiana University for the privilege of consulting him in one or two matters of difficulty. Finally, acknowledgment for invaluable assistance in coping with the mechanical difficulties involved, is due to Miss B. A. Davey.

${ }^{1}$ See the literature noted in Mr. W. Hastie's translation of Kant's Philosophy of Law; also the literature in Mr. Hastie's Outlines of the Science of Jurisprudence (T. \& T. Clark, Edinburgh). A valuable list of juristic literature will also be found in Professor Salmond's Jurisprudence (2d ed., 1907), appendix V, p. 495. 
, 


\section{AUTHOR'S PREFACE TO FIRST EDITION}

Nearly every academic teacher who applies himself to Juristic Survey ${ }^{1}$ approaches it in a different manner according to his experience. Predisposition to this or that special study, a view of the necessity of exalting one study over others, or the unconsciously operating influences of the specialties of teachers, have led to differences of form, and the greatest diversity in its limits, entirely regardless of practical considerations. Occasion to deplore and condemn these variations of Juristic Survey arises from the fact that the materials cover a wide range, admitting of extensive or restrictive treatment interesting from every point of attack.

The object to be attained by lectures on, or the textbook of Juristic Survey, can be attained equally as well, whether one department of study is placed in the foreground more, or another less; or whether the treatment carries with it in the shading of the whole more, or less, of its local color.

1 [The title of this work in the German is, Enzyklopaddie und Methodologie der Rechtswissenschaft (Einleitung in die Rechtswissenschaft). It has, however, been thought desirable to employ the title adopted as less likely than any other to be misleading to English readers. Although authority exists for use of the expression, "Juristic Encyclopædia," there is an obvious objection to the use of the term "encyclopædia" in this connection. The translator has ventured, instead, in the text of this translation to employ the compendious expression, "Juristic Survey," as one free at least from any accidental and erroneous connotation of bulk. In this substitution of terms an escape is also afforded from an implication of mere alphabetic arrangement characteristic of the encyclopædic works generally known to English readers. (See sec. 4, note 2.)

Prof. W. G. Hastings in his translation of Korkunov, General Theory of Law (The Boston Book Co., 1909), designates this study "Encyclopedia of Law." In this connection, and with respect particularly to the position of this study, see Korkunov, op. cit., sec. 2; cf. Hastie, Outlines of Jurisprudence (Edinburgh, 1887), Part V, p. 231, et seq. (Friedländer).] 
I might make the preliminary observation and request, not to reproach this work with bias, and not to require of it that it contain exactly everything that this or that specialist might prefer to find in a Juristic Survey.

It has been my principal endeavor to develop the body of the law logically from the fundamental notion of a standard of protected interests; and to demonstrate positively the applicability of the same basic principle in the construction and arrangement of all divisions of this science. The other objects I have sought to attain are indicated in the first paragraphs of the next.

In the Methodology, I ventured to incorporate thoughts long entertained regarding our system of acadenic instruction, as well as to give expression to views regarding the future form of legal study.

Where, as here, so much depends on an economy of the whole, and on proportion in the use of historical, philosophical and dogmatic material, including suitable references, and inasmuch as the subject will not submit of too great abstraction of form, the writer necessarily must indulge great confidence in the forbearance and liberal treatment of the reader, to whom this book is offered, with the request for his considerate judgment.

Geissen, Spring, 1887. 


\section{AUTHOR'S PREFACE TO SECOND EDITION}

The foreword to the first edition pointed out that I desired to give expression to various thoughts on academic teaching which I had long entertained. It is a matter of satisfaction to me that, at least in considerable part, these notions have prevailed and become a reality. Academic instruction is begun with a systematic, preparatory course,-an introduction to the science of law (Juristic Survey). This fact has made necessary changes in the Methodology,-the revised portion of this book. It has also given occasion to re-examine the details of the first part of the book, while maintaining its systematic form, and to bring it up to date with new material.

This new material is derived principally from the new imperial German law and especially from the German Civil Code. I have attempted to employ the references to this great master-work of German legislation in. such manner that, to a certain extent, in the building up of my system, the evolved ideas leading out first from general, philosophical, or socio-political viewpoints, culminate in the sections of the Civil Code,- - the provisions of the current law, in which they have found their latest development.

The references to the provisions of the Civil Code for the German Empire are sought to be made to such extent and in such arrangement that they may not only practically illustrate legal ideas theoretically developed, but may also serve for general orientation, and be useful for the first introduction in the study of this code.

Königsberg, Aug. 1, 1899. 


\section{AUTHOR'S PREFACE TO THIRD EDITION}

In the present edition, I have attempted to fortify the philosophical portion of the book. The historical part is enlarged on account of the consideration of new historical discoveries; as for example, the Hammurabic Code. The dogmatic part, dealing particularly with rights of personality, and especially, authors' rights, has been supplemented, and in part, revised.

Munich, Jan. 2, 1905. 


\section{TABLE OF CONTENTS}

\section{SYSTEMATIC SURVEY OF THE LAW}

\section{INTRODUCTION}

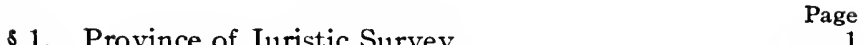

$\S 2$. Necessity of Law, and its Basis ................

$\S 3$. The Science of Law ................... 13

$\$ 4$. Content of Juristic Survey $\ldots \ldots \ldots \ldots \ldots \ldots \ldots$

\section{PART FIRST}

\section{LAW AND ITS SOURCES}

\$5. Law in General ....................... 29

\$6. Law Compared with Morals, Religion, Equity and Social Convention ................... 36

$\S 7$. Foundations of the Legal Structure (System) . . . 49

$\S 8$. The State and Legal Order ............... 62

$\$ 9$. Sources of Law . . . . . . . . . . . . . . 73

$\$ 10 . \quad$ I. Customary Law $\ldots \ldots \ldots \ldots \ldots \ldots \ldots \ldots \ldots$

$\$ 11$. II. Legislation $\ldots \ldots \ldots \ldots \ldots \ldots \ldots \ldots \ldots \ldots, 80$

$\$ 12$. III. Other Sources of Law $\ldots \ldots \ldots \ldots \ldots \ldots \ldots 86$

$\S 13$. Application of Law ................... 88

\section{PART SECOND}

SYSTEMATIC CLASSIFICATION OF THE LAW

$\$ 14$. Focal Point and Survey of the Legal System $\ldots \ldots . \quad 93$

(A) CIVIL OR PRIVATE LAW

\$15. Elements of Civil or Private Law .......... 102

\$16. System of Civil Law and its Development in Germany........................ 111 
THE SYSTEM OF CIVIL LAW IN DETAIL

\author{
CHAPTER I \\ THE LAW OF PERSONALITY
}

817. The Law of Personality in General. ............ Page

18. Rights of Personality in Detail ........... 125

CHAPTER II

THE LAW OF MATERIAL THINGS

19. The Law of Things in General ............ 136

\$20. The Law of Ownership ................. 139

21. Real Rights in re aliena ................. 149

CHAPTER III

\title{
THE LAW OF OBLIGATIONS
}

822. Law of Obligations-General Part............ 157

823. (a) Obligations Arising out of Agreement ....... 162

24. (b) Obligations Arising out of Unlawful Acts...... 173

CHAP'TER IV

\section{PURE FAMILY LAW}

825. Pure Family Law-General Part ........... 176

8 26. (1) Marriage ..................... 179

8 27. (2) The Relation Between Parents and Children... 18;3

\& 28. (3) Other Blood Relations, and Relationship by Marriage ..................... 186

\$29. 4. Artificial Relationship ............... 1s

CHAPTER V

\section{FAMILY PROPERTY}

8 30. Family Property in General. . . . . . . . . . . . . . 189

31. (1) The Matrimonial Régime .............. 192

32. (2) Property of Children................ 198

\$3. (3) Guard anship Administration of Property ..... 200 
CHAPTER VI

INHERITANCE

$\S 34$. Inheritance in General .................. 202

\$35. Natural Succession .................... 208

$\S 36$. Testamentary Succession................. 211

\section{(B) PUBLIC LAW}

\$ 37. Elements of Public Law $\ldots \ldots \ldots \ldots \ldots \ldots \ldots . \ldots \ldots$

\$38. Divisions of Public Law ................ 218

[First Division of Public Law]

PUBLIC LAW OF THE STATE

CHAPTER I

THE STATE AS SUBJECT OF STATE INTERESTS

\$ 39. State Law-General Part . . . . . . . . . . . 220

$\$ 40$. Objects of the State (its Teleology)........... 223

$\$ 41$. Theories of the State $\ldots \ldots \ldots \ldots \ldots \ldots \ldots \ldots 226$

CHAPTER II

\section{LAIV GOVERNING STATE ACTIVITY}

$\$ 42$. Organs of Expression of State Power .......... 230

\$ 43. Methods of Expression of the Power of the State... 235

\$ 44. Constitutional Law (State Law in Narrow Sense) .. 240

$\$ 45$. Administrative Law .................... 243

\section{CHAPTER III}

\section{OBJECTS OF STATE ACTIVITY}

$\$ 46$. State Sovereignty and State Interests ........ 245

$\$ 47$. Iegally Protected Chief and Auxiliary Interests of the State in Detail .................... 247 
INTEREST OF THE STATE IN LAW, AND SOVEREIGNTY OF JUSTICE IN PARTICULAR

\$48. Administration of Justice and the State ....... 254

$\$ 49$. I. Civil Law and Non-Contentious Jurisdiction .. 260

$\$ 50$. II. Law of Civil Procedure . . . . . . . . . 265

$\$ 51$. III. Criminal Law . . . . . . . . . . . . 272

\$52. IV. Criminal Procedure $\ldots \ldots \ldots \ldots \ldots \ldots \ldots .279$

\$53. V. Administrative Jurisdiction $\ldots \ldots \ldots \ldots \ldots 284$

[Second Division of Public Law]

INTERNATIONAL LAW

85. Notion, Signification and Sources of International Law ......................... 287

\$55. Systematic Survey of the Content of International Law ......................... 289

\section{SUPPLEMENT TO PRIVATE AND PUBLIC LAW}

\section{SPECIAL LAW OF PROFESSION AND POSITION}

\$56. Special Law-General Part ............. 292

\$57. Church Law ....................... 296

\$58. Commercial Law ................... 300

\section{METHODOLOGY OF LEGAL SCIENCE}

859. Nature and Object of the Methodology of Legal

Science ......................... 303

$\$ 60$. Departments of Legal Science ............. $30 \pi$

\$61. Methods of Study and Academic Education ...... 317

\section{APPENDIX}

Systematic Classification of the Law (tabulated) ...... 331

Recent German Literature ................. 33 


\section{ABBREVIATIONS}

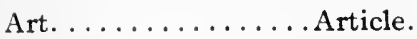

Bd. ............... Band (volume).

B.G.B........... Bürgerliches Gesetzbuch für das Deutsche Reich (German Civil Code).

Birkmeyer, Enz......Birkmeyer, Enzyklopädie der Rechtswissenschaft (1907).

Bl.R.A. ......... Blätter fïr Rechtsanwendung, also Seuffert's Blätter fïr Rechtsanwendung.

Cosack, B.R. .......Lehrbuch des deutschen Bürglerlichen Rechts by K. Cosack (4th ed., 1903).

C.P.O. (Z.Pr.O.) .....Zivilprozessordnung (Civil Procedure Act of May 20,1898).

Einf.G. . . . . . . . Einfïhrungsgesetz (Introductory statute). Enz............Enzyklopädie (survey).

E.R.W. v. H......... . Holtzendorff's Enzyklopädie der Rechtswissenschaft, 5th ed.

Freiw.G.G. . . . . . Reichsgesetz ïber die Angelegenheiten der freiwilligen Gerichtsbarkeit (non-contentious jurisdiction statute of May 20, 1898).

Gareis, B.G.B. ...... Bïrgerliches Gesetzbuch (German Civil Code, with notes, and index by Karl Gareis (Giessen, Emil Roth)).

Gareis, H.G.B....... Handelsgesetzbuch (Commercial Code with notes etc., by Karl Gareis (C. H. Beck, Munich, 3d ed., 1905)).

Gareis, H.R....... Das deutsche Handelsrecht (German Commercial Law, etc., by Karl Gareis, 7th rev. ed., Berlin, 1903).

Gareis, R.G. ........German statutes separately printed (Emil Roth, Giessen).

Gen.Ges. .........Genossenschaftsgesetz (company statute of May 1, 1889, revision of May 20,1898).

Ges. m. b. H. ......Gesellschaft mit beschrünkter Haftpflicht (limited liability partnerships) statute of April 20, 1892, revision of May 20, 1898.

Gew.Ord. . . . . . . Gewerbeordnung (trade regulation statute) of July 26,1897, with amendments, 1901 .

Grundb.Ord......... Deutsche Grundbuchordnung (land registration statute) of March 24, 1897, revision of May 20, 1898. 
Hdbch............. Handbuch (manual).

H.G.B. ........... Handelsgesetzbuch (Commercial Code) of March 24, 1897 (R.G.Bl. 1897, No. 23, p. 219).

Inst............. Institutionen (institutes).

J.L.B. v. K. ......Juristischer Literaturbericht (1884-1894) by A. v. Kirchenheim with the cooperation of H. Erman, A. Frantz, K. Gareis, G. Kleinfeller, C. F. Reatz, G. R. v. Salis, H. Sommer, and F. Stoerk (Leipzig, J. C. Hinrichs, 1895).

K.O. ............. Konkursordnung (Bankruptcy Act) of May 20, 1898.

K. u. v. Holtz. Enz. .Holtzendorff's Enzyklopädie der Rechtswissenschaft, 6th ed. rev., by J. Kohler, 2 vols.

Lehrb. ............ Lehrbuch (treatise).

L.R..............Landrecht

L.U.G............ Statute relating to literary and musical copyright (June 19, 1901; R.G.Bl. 1901 , No. 27, p. 227).

Mark Ges......... Trade Mark Act of May 12, 1894.

Marquardsen, Hdbch.. Marquardsen's Handbuch des offen'lichen Rechts.

Must. Ges. ........ Useful Models Act of June 1, 1891.

Pand............. Pandekten (pandects).

Rechtswiss........ Rechtsuissenschaft (Science of Law).

R.G. and R.Ges....... Imperial statute.

R.G.Bl. .........Reichsgesetzblatt (Imperial Legislative Bulletin).

R.Bk.Ges..........Bank Act of March 14, 1875.

R.Ger. .......... Reichsgericht (German Imperial Supreme Court).

R.Gesch. ........ Rechtsgeschichte (legal history).

R.O.H.G. ........Reichsoberhandelsgericht (Imperial Supreme Court of Commerce).

R.Vf. .......... Reichsierfassung (Imperial Constitution). Str.P. . . . . . . . Strafprozess (Criminal Procedure).

Str.G.B. . . . . . . Strafgesetzbuch (Criminal Code).

V.G............Act relating to publishers of June 19, 1901 (R.G.Bl., 1901, No. 27. p. 217).

W.O. ..........Wecnselordnung (Bills of Exchange Act).

Z. (Zeitschr.) ....... Zeitschrift (periodical). 


\section{TABLE OF REFERENCES TO THE GERMAN CIVIL CODE (B.G.B.) \\ AND THE \\ INTRODUCTORY STATUTE (Einf.G z. B.G.B.)}

[Indicating the sections of the Code, the articles of Introductory Statute, and the pages of this translation. The section given is usually one of a consecutive series and is always the first in such series.]

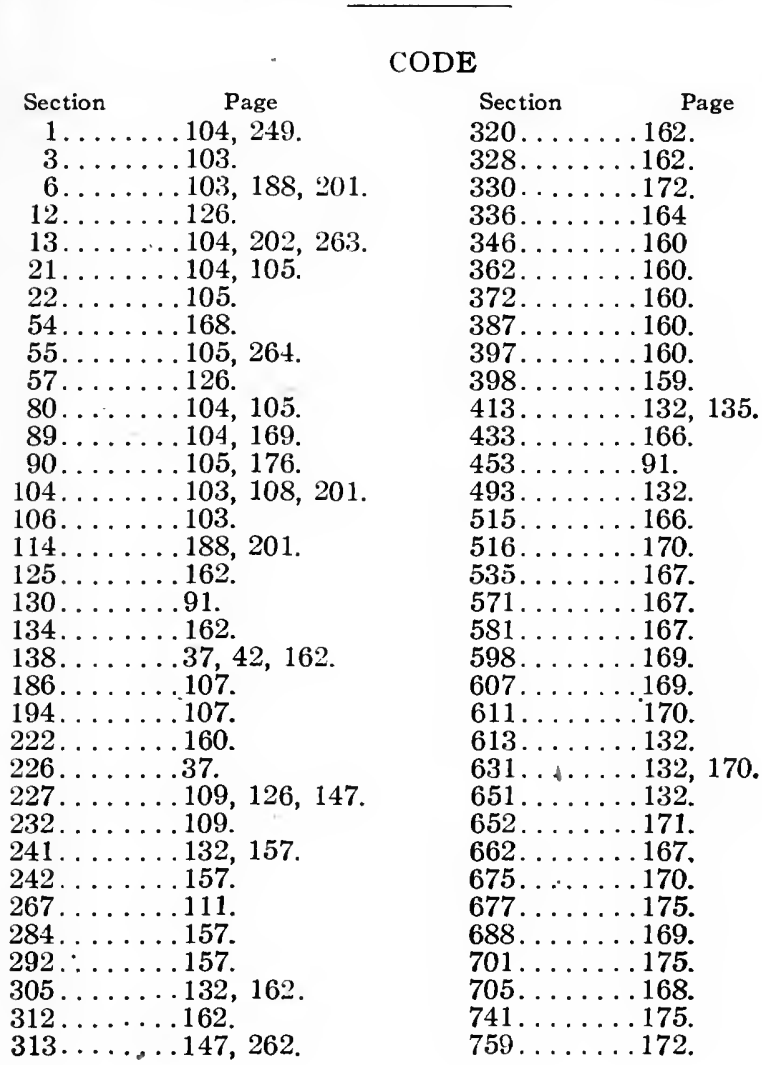


xxviii

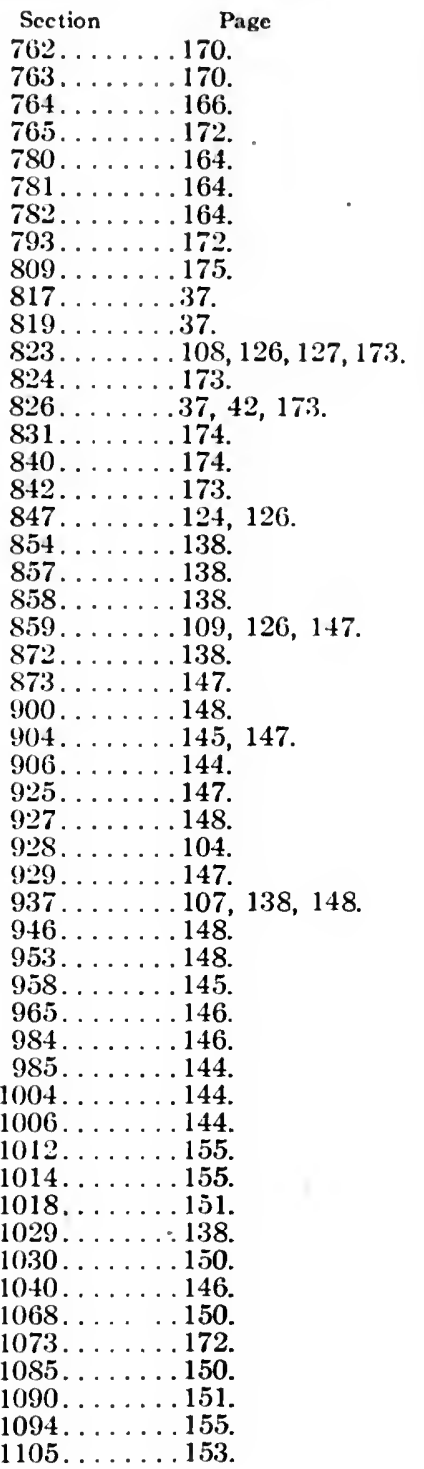

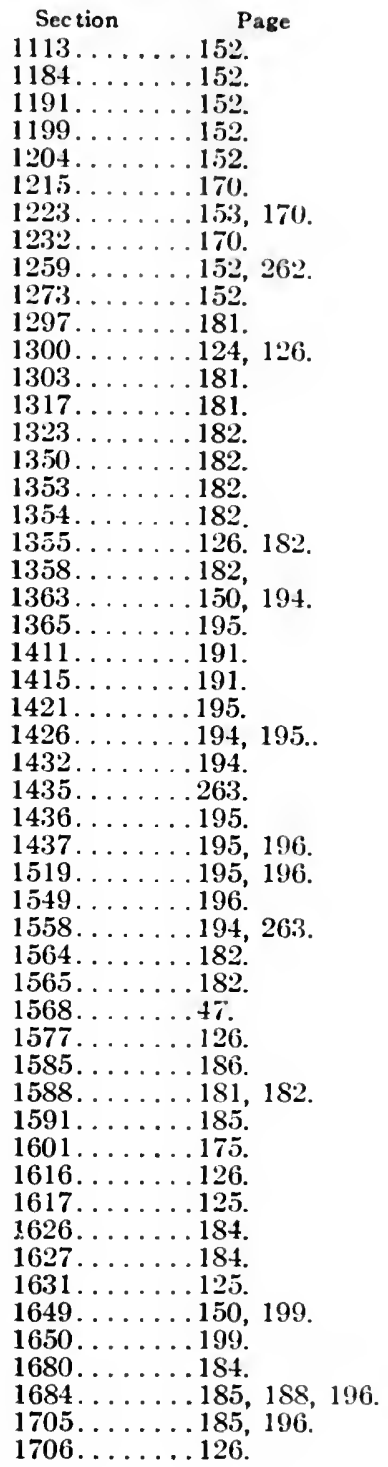




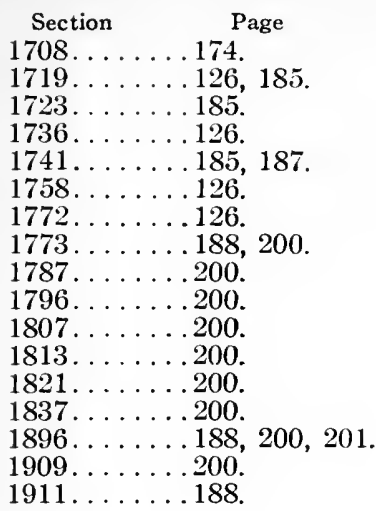

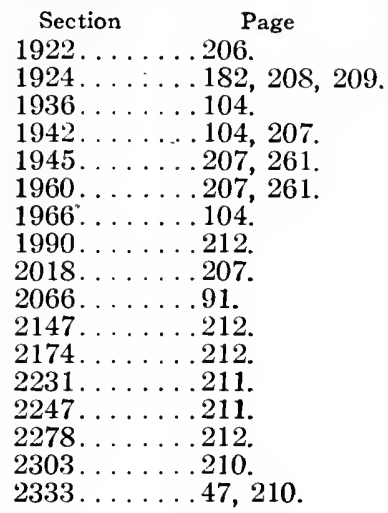

\section{INTRODUCTORY STATUTE}

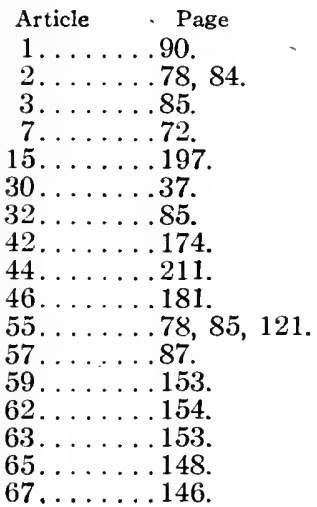

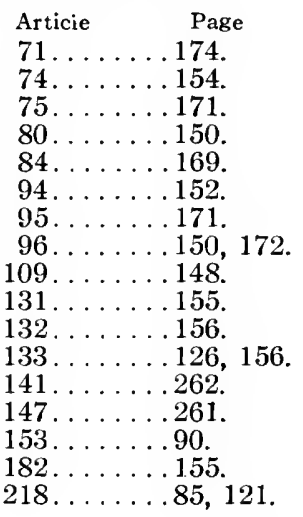


, 


\section{SCIENCE OF LAW}

\section{INTRODUCTION}

\section{SECTION 1}

\section{PROVINCE OF JURISTIC SURVEY}

Juristic Survey is a systematic review of the whole domain of the law, ${ }^{1}$ whether of one or more peoples or states; whether in a particular period or in various stages of legal development. ${ }^{2}$

The object of this systematic survey is-

1. To furnish to beginners a fundamental introduction to the science of law:-the propædeutic to jurisprudence;

2. To afford to those engaged in particular departments of legal science a survey of these separate departments, based on fundamental notions:- the recapitulation of the elements of special studies;

1 [The German language requires a very awkward phrase to express the notion of law used in an abstract sense. A similar difficulty is presented in the German equivalent for a right in the concrete sense. Law (abstract)= Recht im objektiven Sinne. Right (concrete)=Recht im subjektiven Sinne.

The term Recht standing alone and unqualified, in the substantive sense, means, either: (1) a right, claim, title, privilege, immunity, power; or (2) law, justice.

The context is usually sufficient to indicate the sense. There is ordinarily less danger of confusing rights, in the concrete, with law in the abstract, than of giving the term Recht an ethical turn when the juridical sense is intended. Mr. W. Hastie in his translation of selections from the Juristic Surveys of Puchta, Friedlānder, Falck, and Ahrens (Outlines of Jurisprudence, Edinburgh, 1887) has frequently fallen into this error. Professor Dyde has marred his translation of Hegel's Philosophie des Rechts (1820) in a similar manner (Hegel's Philosophy of Right, Geo. Bell \& Sons, London, 1896). See Holland, The Elements of Jurisprudence, 1st Am. ed., *73; Salmond, Jurisprudence, 2d ed. (London, 1907), 465.]

Concerning the, notion Recht im objektiven Sinne, see p. 29; also, the contrary notion, see p. 31 (Rights).

${ }^{2}$ Compare A. Merkel, Juristische Enzyklopädie, p. 1. 
3. To furnish the scientific generalization and basis of the various departments of the law, and the separate studies in legal science; in such nanner that these detailed parts may be seen to be the divisions of an organized unity, arising as an imperative of reason, from the attributes of human nature itself. This is the philosophical object of Juristic Survey.

4. Finally, Juristic Survey affords the framework of comparaive law, ${ }^{1}$ which in its turn serves in part for the illustration of the study of positive law, and in part provides the basis for Philosophy of Law.

${ }^{1}$ Comparative Law as the basis of Philosophy of the Law. See F. Dahn, in Zeitschr. f. vergleichende Rechtswissenschaft, Bd. II, p. 1; further, Bernhớt, Ueber Zweck und Mittel der vergleichenden Rechtswissenschaft. ibid, Bd. I, p. 1 . and Bd. II, p. 255, note. Compare also below (sec. 3, p. 21, note 1) Bekker's observation in opposition to Bierling: Kohler. Das Recht als Kulturerscheinung. Einleitung in die vergleichende Rechtswissenschaft (1885), and his Recht und Prozess in Grünhut's Zeitschr., Bd. XIV, p. 1. Compare also Kohler's investigations in comparative law, with reference to the law of obligations, the law of liens, matrimonial law, and the family law, of India; the ancient legal records of Assyria and Babylon (Zeitschr. f. vergleich. Rechtswissenschaft, Bd. III, pp. 161,343, 201); and numerous other contributions by Kohler, particularly ibid, Bd. V; also Gareis, in the Deutsche Revue, II Jahrgang, Heft 6 (March, 1878), p. 302. The extremest caution must be exercised in reaching conclusions in the comparison of the laws of different peoples whose social conditions are not completely and accurately understood. Compare the conclusions of $\mathrm{K}$. v. Prantl in the Krit. Vierteljahrsschrift, Bd. XVI (1874), p. 265, concerning the collection of materials of A. H. Post (Einleitung in eine Naturwissenschaft des Rechts) and A. Bastian (Die Rechtsverhältnisse bei verschiedenen Volkern der Erde), in the fullest recognition of systematic works on comparative law; as, for example, Ed. Ganz (Inheritance Law), or Unger (Matrimonial Law). See also Kohler, Krit. Vierteljahrsschrifi, N. F. Bd. IV (1881), pp. 1, 161. 


\section{SECTION 2}

\section{THE NECESSITY OF LAW, AND ITS BASIS}

It is necessary to take into account the nature of man in order to know the nature of law and its objects; for it is here that we find what may be called the basis or roots of the law.

One of these roots-we may call them the materialsis self-interest, or egoism. ${ }^{1}$ A great variety of necessi-

${ }^{1}$ This starting point of a theory of law is not new. It is found as early as the ancient Indian law book which bears the mythical name of Manu. It is disclosed in Sanskrit legal literature, and is rooted in the numerous legal, ethical, and social regulations (dharma) of Vedic times (consequently prior to 600 B. C.).

The occasion for the so-called laws of Manu appears to have been the establishment and security of the basic principles of Brahmanism relating to the state and law, in opposition to the counter influence of Buddhism.

This ancient Brahmanic code says among other things: "To act solely from a desire for rewards is not laudable, yet an exception from that desire is not (to be found) in this (world); for on (that) desire is grounded the study of the Veda and the performance of the actions prescribed by the Veda": [this and following excerpts from Manu are taken from Georg Bühler's translation in Sacred Books of the East, Vol. 25, ed. by F. Max Müller]. - Manu II, 2. "The desire (for rewards), indeed, has its root in the conception that an act can yield them, and in consequence of (that) conception sacrifices are performed; vows and the laws prescribing restraints are all stated to be kept through the idea that they will bear fruit."-Manu II, 3. "Not a single act here (below) appears ever to be done by a man free from desire; for whatever (man) does, it is (the result of) the impulse of desire."Manu II, 4. "He who persists in discharging these (prescribed duties) in the right manner reaches the deathless state and even in this (life) obtains (the fulfillment of) all the desires that he may have conceived."-Manu II, 5.

With reference to the jurioical portions of the code of Manu, see Julius Jolly in the Zeitschr. f. vergleich. Rechtswissenschaft, Bd. III, p. 232; Bd. IV, p. 321. Concerning the origin, age, and arrangement of this code see Julius Jolly in Georg Bühler's Grundriss der indo-arischen Philologie und Altertumskunde, Bd. II (1896), pp. 14, 16-19.

[The laws of Manu were translated into the English by Sir William Jones (1794); and under the title, The Ordinances of Manu, with an introduction by Burnell, and completed by Hopkins (1886).]

This starting point of all legal order may also be recognized in the Prologue of the most ancient known code,- that of the Babylonian King Hammurabi, in which the lawgiver and king says: "Anu and Bel called me Hammurabi, 
ties-necessities of an animal and of an ideal natureimpel human beings to action, and to conflicts in the outer world. The necessity of subsistence, the requirement of rest and sleep, shelter and clothing, and manifold wants of a physical and ideal character, are the basis of man's activity. If men, not living an isolated life, should satisfy their wants without regard to others, the struggle of all against all (bellum omnium contra

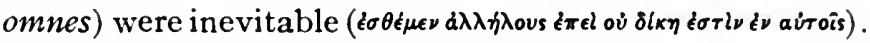
The struggle, however, does not come to this. ${ }^{1}$ The very necessity of rest, and security as to certain wants in at least a limited measure, transforms egoism in its grosser aspect into a refined egoism. By virtue of these necessities the individual renounces the satisfaction of certain wants in order that he may the better enjoy

the exalted prince, the worshiper of the gods, to cause justice to prevail in the land, to destroy the wicked and the evil, to prevent the strong from oppressing the weak, to go forth like the Sun over the Black Head Race, to enlighten the land and to further the welfare of the people." (The code of Hammurabi translated by Robert F. Harper, Chicago, 1904. See also the codes of Hammurabi and Moses by W. W. Davies, 1905; Code of Hammurabi translated by C. H. W. Johns, Edinburgh, 4 th imp., 1903.]

The code of Hammurabi [now in the Louvre at Paris] is carved on a dioritic column, found through the French excavations in Susa in 1897-99. It was enacted by Hammurabi (Amraphel. Ammu-rapaltu, King of the Westland) who ruled over Babylon, $2250 \mathrm{~B}$. C. He reigned fifty-five years, and was a contemporary of Abraham (Mos. I, 14, 1)

Concerning this highly important legislation with reference to universal law and the history of civilization, see Scheil, Delegation en Perse,-Mémoires publiés sous la direction de $M$. I. de Morgan, délégué général (Tome IV). Textes Elamites-Sémitiques, deuxième série; par V. Scheil, Professeur d l'École pratique des hautes etudes (Paris, Ernest le Roux, 1902). See further Winckler, Die Gesetze Hammurabis, König von Babylon, translated by Dr. Hugo Winckler (Der alte Orient, Jahrg. IX, Heft 3), Leipzig. Hinrichs, 1902; also published under special title, 2d ed., 1903. See further Hammurabis Gesetz by J. Kohler and F. E. Peiser, Bd. I, Uebersetzung, juristische Wiedergabe, Erläuterung (Leipzig, Ed. Pfeiffer, 1904), and the literature therein noted on p. 106; also Hugo Winckler in Grünhuts Zeitschrift, Bd. XXXI (1904), p. 373 .

1 This condition of strife is seen at once without further explanation to be only the counterpart of social life. See Stammler, Wirtschaft und Recht nach der materialistischen Geschichtsauffassung (Leipzig. 1896), pp. 543-545. Concerning this work see Fr. Keller in Krit. Vierteljahrsschr., Bd. 39 (1897), pp. 483-528. 
others. The weaker members of society (principally. those weaker by nature,-women and children,- and those physically inferior individuals in a position of servitude) accept from the beginning the fact that, in this assumed struggle, they would be at a disadvantage. On physical or physiological grounds, a part of humanity bows to the power of dominant individuals, as is seen in domestic or family authurity.

This relation is also based on an ethical ${ }^{1}$ foundation. It leads directly to the organization of the state, with a system of legal order. The dominant subject, the free and physically capable man, sets up his will in the household, by virtue of his authority, and this makes the basis of the legal community: (See below the significance of kinship.)

Outside the household, however, there would still be violent collision of interest against interest, and unregulated egoism opposed to egoism, if there were not other influences operating on the nature of man, against an unrestrained egoism, and ordinarily counteracting it. Of these other influences, the fundamental principle of human reason (which asserts itself alongside of the fundamental principle of human existence,- - the struggle to satisfy the necessities of the body) is preeminent.

\footnotetext{
${ }^{1}$ Here may be already noted the interposition of ethical influences, discussed below (pages 40,67), with especial reference to their opposition to the principle of pure utility. Subjection to the power of civil society depends far less on this or that content of legal command, than on voluntary submission to an organization whose authority we recognize, and in which we feel the duty to obey in so far as we are a part of the whole and share its advantages and disadvantages, - the social instinct. This sense of voluntary submission. to order, and co-operation, begins for mankind in general, as for the individual in the family, first in the household, and then among the kindred. With regard to the importance of ethical influences as opposed to the narrow view of conscious deliberation, see the observations of $L$. Goldschmidt, Universalgeschichte des Handelsrechts, p. 17, note 6, against v. Ihering, Der Zweck im Recht, Bentham, and others.
} 
Herein lies an ideal root of the law. Man is endowed with the capacity-and it is necessary for the ordering of his sensations and experiences-to reason ${ }^{1}$ from the particular to the general; to discover from single phenomena their overruling genus; and therein the logical or natural law. The mental life even of a child consists of arrangement and summing up of each experience under fewer ideas ${ }^{2}$ attained by the same operation, supplemented by instruction, education, and suggestion. Such is also the method of the scientist who makes an experiment in electricity, or a chemical analysis. Such is the method of the jurist who defines "murder," or "lease," and places "murder" under the more general idea of "crime," and "lease" under the higher notion of "agreement," and "agreement" again under "declaration of intention"; and classifies "crime" and "declaration of intention" under the notion "act." All reasoning is therefore generalization. The highest point of this generalization is all that is conceivable under the absolute.

Man also apprehends himself, in nature, as an object of generalization; that is, as an object of his knowledge. He forms a conception of himself as a member of the genus "man." He next generalizes the notional, and finally, also, the practical arrangement and organization within the genus, manifesting the same principle of reason which governs even the thoughts of the child. Logically as well as practically, the necessity of order follows. This order is a standardized adjustment of the social relations of the members of the genus among themselves. It embraces also matters of property;

\footnotetext{
1 Compare Felix Dahn, Die Vernunit im Recht: Grundlagen der Rechtsphilosophie (Berlin, 1879); also his Ueber Werden und Wesen des Rechts (in der Zeitschrift für vergleichende Rechtswissenschaft, Bd. III (1880)).

2 According to Kant, the necessary form of knowledge of order must be based on innate faculties. Compare below, p. 40, note 2 .
} 
that is to say, the objects of the satisfaction of necessities.

Alongside of the necessity above discussed, which asserts itself as egoism in a gross and in an ideal aspect, peculiar altruistic impulses are recognized in all known stages of civilization, collateral to the egoistic tendencies of mankind. These altruistic impulses, in part, follow closely the material and sensual necessities of the egoistic nature. They are made evident in the domestic impulse, the family sense; and also in the strong feeling of tribal connection. They incline also partly toward human ideals, or cosmopolitan feelings. This is apparent in state feeling, patriotisn, the universal love of man, and the associational impulse. Through such impulses as the feeling of comradeship, social position, esprit de corps, etc., mankind has become socially differentiated in a large variety of distinct groups or organizations.

In so far, however, as it postulates the subordination of the conscious ego to its environment, the law of reason requires a certain moderation of and harmony between egoistic and altruistic impulses. This gives rise to the legal sense, and the legal impulse. This is the inclination toward external order. It is a harmonization of these two different tendencies in an impulse toward the maintenance of this order,-the sense of justice.

Corresponding to this impulse toward legal justice is what Ihering calls "the life through and for others," established and manifested in human nature in the tendency which the Greek philosopher had in mind when

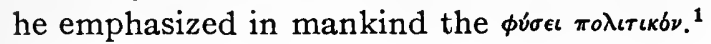

1 Compare, Aristotle Polit. I, 1, 9; W. Oncken, Die Staatslehre des Aristoteles (1875), Bd. II, p. 14; Cicero, de fin. V, 23. According to the statement of Eduard v. Rindfleisch, Neo-Vitalismus, Vortrag auf der Naturforscherversammlung (Leipzig, 1895), all sense of order, and the noble principle, "one for all, all for one," must be considered as innate. Rindfleisch finds even 
The sense of order and the laws of reason, in themselves, do not create law. There is still necessary the social or community sense. ${ }^{1}$ All these impulses are coincident in the nature of man, even though in different stages of development. ${ }^{2}$ It is self-evident that egoistic and

in the lowest activities of life the roots of this principle, from which he derives a law of nature and the highest precept of ethics.

Compare Dig. I, 2, I, 3 (de legibus) (Marcianus, referring to Demosthenes and Chrysippus). In any event, the inclination toward order and society may be demonstrated according to instinct. The bee works in the hive, and the ant performs the labor necessary to its community, according to instinct, in the same manner as human beings, but with extraordinary precision and certainty. The English scientist, Sir John Lubbock, believes that it must be admitted that it is really difficult for the observer of these animals (particularly bees) not to ascribe to them conscious mental capacity. See Sir John Lubbock, The Senses and Instincts of Animals, (1888), translated [into German] by Wm. Marshall (Leipzig, F. A. Brockhaus, 1889, p. 255).

'The capacity is hereby presupposed of perceiving pleasure and pain, and accordingly of estimating and practically attaining values, including mosal values. Conceming this notion, and particularly with reference to the connection between being and the universal feeling of pleasure and pain, and between esthetic and moral values, see Ludwig Busse, Philosophie und Erkenntnistheorie (Leipzig, S. Hirzel, 1894), pp. 136-140. Regarding the related "social instinct," see below, p 9, note 1 (Exner). The concordance of egoistic and altruistic impulses is the hope of philosophy and the effort of Christianity. Compare, on one hand, Herbert Spencer, The Principles of Sociology (translated [into German] by Vetter and Carus, Die Prinzipien der Soziologie, Bd.. IV, Stuttgart, 1897, sec. 853, p. 673); and Matthew xxii. 39; Mark xii. 31, on the other. Compare also, on the philosophical side. Ludwig Busse, Die Weltanschaungen des grossen Philosophen der Neuzeit (Leipzig, B. G. Teubner, 1904, p. 159).

2 Anarchy for this reason is diametrically contrary to the nature of man. Even in the profoundest convulsions of the state, including the abolition of the head of the state, anarchy is never fully possible without instantaneous retribution, and, except temporarily, is inconceivable. Legal rules have become in so great a part intensely customary, or their observance, to so great a degree, commanded and maintained by habit, that even a general proclamation of freedom from law would not at once work any essential change in the manner of life of the people, except in the immorally inclined members of society. It is true that in such event the greatest excesses might be feared from those persons not restrained by custom or morals, unless the conviction of the necessity of legal order should thereby be manifested to those very persons who require such persuasion. Accordingly, the supposed customary five days' suspension of law on the death of a Persian king must be classed as a badly chosen method of demonstration ad ocklos of the high value of law and kingly power. A definite stability of official activity must be assumed, without any interruption of its force on the part of the head of the state, and particularly in the face of a short period of interregnum. The law itself and the head of the state would be devoid of 
altruistic impulses have a connection with each other and with metaphysics, ethics, and particularly with religion, inasmuch as they have a common starting point. All these impulses and ideas are products of the nature of man.' The sense of order, as well as the social instinct, proceeds from a human impulse,- - the necessity of satisfying the "self." It is accordingly clear that even in the most primitively governing or governed community, whether it is called the primitive ${ }^{2}$ patriarchal state, or the primitive hero state, a psychical factor-the ethical impulse-operates alongside of physical facts of dominion and submission. The ethical sense, in conjunction with objective facts (such as kinship, physical power, and constant defensive and offensive capacity on one hand, and the necessity of protection and dependence on the other), creates and governs family life.

Ages perhaps have passed since the social life of man was differently ordered than through the basis of kinship. This primitive order arises and is built up from principles (rules) governing the external relations of men

force without official activity of the civil and military authorities conformably to law. See below, Public Law, Secs. 42-47. Reference is made to the purpose of the alleged ancient Persian d $\nu 0 \mu i a$ in Joh. Stobaeus, $\pi \epsilon \rho \iota$ $\nu \delta \mu \omega \nu$ kal $\epsilon \theta \omega \nu$, and in Sextus Empiricus, $\pi \rho \dot{s}$ ṕtropas.

${ }^{1}$ This position agrees with the able statement of Siegmund Exner, Die Moral als Waffe im Kampf ums Dasein (Vienna, 1892). While Exner does not regard it as belonging to the nature of man as such to further the objects of society, of which certain ideas and perceptions may be generated by means of property transferable by inheritance, yet he posits in the species man the capacity of perception of well-being, in the observance of the welfare of society. The social instinct is a vital force of humanity, and for modern man at least, the necessity of law is inborn.

A special development of the ethical thought, the "life for others," is found in Christianity in the new command of the love of others. Compare W. Oncken, Aristotele, Bd. II, p. 70; Matthew v, 44 (Sermon on the Mount); John xiii, 34. 35.

${ }^{2}$ As the external order of law can come only from the community, that is the governing society, and not from individuals, therefore law is social will. Compare the following note. 
in society. It is a peaceable order, in that it does not employ, but obviates, conflict. It is a reasonable order, in that it expresses the principles of human reason as well as the principles of human nature. The essential character of law rests here. Law (Friedensordnung) peaceably adjusts the external relations of persons among themselves, and to things.

The object of this peaceable adjustment is protection, in a manner peculiar to the law, of interests which individuals and the community have in their relations to others, and to things. It is an adjustment of the means of external satisfaction of necessities. Law protects such interests in its own way through a limitation on freedom of action by means of positive ${ }^{1}$ rules

1 "Positive," that is to say, imposed; proceeding from the community through the dominant authority of society, whether in form of statutes or customary law. The regulation of social relations through self-generated standards alone-that is to say, through so-called immanent legal principles (the theory of anarchy)-is an insecure and insufficient basis. Regarding the theory of anarchy see Zenker, Der Anarchismus. Kritik und Geschichte der anarchistischen Theorie (Jena, 1895); and compare Rudolf Stammler, Wirtschaft und Recht nach der Materialistischen Geschichtsauffassung (Leipzig, 1896), p. 261. It is true that positive law is always the outward development and expression of the immanent standards of continually changing social conditions, and that this is to be recognized by the lawmaker, and indeed is in part unconsciously observed; and that the judge in the interpretation of statutes, and the construction of acts manifesting legal consequences, must bear this in mind. Concerning the so-called "Gesetz der Immanenz" as the highest principle of the legal system, see L. Goldschmidt, Hdbch. d. $H . R ., 2 \mathrm{~d}$ ed., I, sec. 34, p. 302, and Universalgeschichte d. H.R. (1891), p. 33. Contra: Bierling, Kritik d. jurist. Grundbegriffe, I, p. 83 . See also J. Kohler, Jahrb. f. Dogm., Bd. XXVI (1888), pp. 1, 184; A. Merkel, Jurist. Enz., p. 13; Gareis, Lehrb. d. H.R., 5th ed., pp. 2, 434, 435; R. Stammler, Das Recht der Schuldverhältnisse in his allg. Lehren (1897), pp. 3, 7; R. Stammler, Die Gesetzmössigkeit in Rechtsordnung u. Volkswirtschaft (Dresden, 1902), p. 24.

IThere is no juristic idea more difficult of clear and adequate apprehension than the notion of law itself. The various schools of jurisprudence owe their origin, and find their differences among themselves, in variants of this basic conception. It must not be imagined that these differences are of purely academic importance; for they have led to highly practical consequences in the history of legal evolution. Any definition of law is incomplete which does not take account of all its elements, which is practically tantamount to saying that it can not successfully be defined. Certainly no definition is complete which does embrace its basis or causes. The most approachable 
in form of commands or prohibitions. Limitations are established through these rules on the range of activity of individuals, and also of the community, by which arbitrary freedom of choice is removed, and by which freedom within a limited sphere is legally guaranteed. Interests lying within the sphere of legal guaranty become, by reason of this legal guaranty, legal interests, legal advantages. Relations of fact, through the protection which is afforded by commands and prohibitions, become legal relations, legally ordered relations.

The necessity of law is satisfied, in that the whole range of human activity, of individuals as well as of the community, is protected by rules of law; in that it is shielded from an unrestrained freedom of will; and

avenue of definition is that which describes the social results of law. Thus, the author says that law "peaceably adjusts the external relations of persons."

The elements of law with reference to which it may be defined and considered are:-

1. Its basis in nature, reason, ultimate reality, or religion, if any such it has; or its causes, as in the nature of man, or society;

2. Its sources, or the materials out of which it arises, as custom, precedent, and legislation;

3. Its effects;

4. The method of its formal expression and authoritative application;

5. Its ends.

Thus, Cicero defines law by an assumed basis in nature: Lex est ratio summa, insita in natura, que iubet ea qua facienda sunt, prohibetque contraria.De Leg., I, 6.

Stahl defines law from a theological standpoint: In order to apprehend the nature of law, it is necessary to consider it in the totality of the relations upon which it operates, as a great institution established by God, for their definite regulation. (Philosophie des Rechts, Vol. 1I, Bk. 2, pt. 1, cap. 1.)

Montesquieu finds the basis of law in human reason: Law in general is human reason. (L'Esprit des Lois I, 3.)

Gareis looks to the nature of man: To know the nature of law and its objects, it is necessary to take into account the nature of man. (Supra, sec. 2.)

Gratian regards the sources when he says: Ius generale nomen est: Lex autem iuris est species, . . . o omne autem ius legibus et moribus constat.

Savigny defines law by its social effects: The rules whereby the invisible boundaries are determined within which the existence and activity of each individual attains security and free scope. (System des heut. Röm. R., I, 52.) 
in that, accordingly, the manifestation of this activity (which is requisite to the realization of the social destiny of humanity) is guaranteed within these limits. "The highest ends of humanity are attained only through the free development of powers, but this development would be impossible without law. It is the law which prepares the way for all human advancement."1

Salmond looks to the agency by which (Anglo-American) law is expressed: Law is the body of principles recognized and applied by the state in the administration of justice. (Jurisprudence, cap. 5.)

Blackstone expresses the imperative notion: A rule of civil conduct prescribed by the supreme power in a state commanding what is right and prohibiting what is wrong. (Commentaries, I, 44.)

These formulas from which the above illustrative selections werc made are conveniently assembled in Prof. Roscoe Pound's Outlines of Jurisprudence (Jacob North \& Co., Lincoln, Neb., 1903). Other collections of formulas may be found in Holland (Elements of Jur. p. 20) and Korkunov (Theory of Law, Prof. Hasting's tr., p. 81).

The text illustrates the notion of law as a means for the attainment of the social destiny of man. In this view the law has not merely an in hibitory influence, but has also a constructive purpose. This view of the law as a social instrument opposes itself to the notion of Korkunov, who defines it as a "delimitation of interests" (op. cit., p. 52).

With reference to the Schools of Jurisprudence which have sprung from differences in the conception of the nature of law, see the monograph of Prof. Roscoe Pound, A New School of Jurists (University Studies, Lincoln, Neb., Vol. IV, No. 3, July, 1904).

In broad outline, the Schools of Jurisprudence may be represented by the following diagram:-

I. The Material Conception.

(I) Imperative.

(2) Historical.

(3) Sociological.
II. The Ideal Conception.

(I) Dogmatic.

(2) Rational.

(3) Metaphysical.

The Imperative School regards law as something commanded by the state (type: Austin). The Historical School contends that law is an unconscious development, like a language (type: Savigny). The Sociological School asserts that law is a complex of social evolution and social elements (type: Post).

The Dogmatic School assumes that law proceeds from a higher authority than the state (type: Augustine). The Rational School finds the basis of law in reason (type: Cicero). The Metaphysical School discovers the immutable foundations of law in transcendental reality (type: Kant).]

1 Windscheid, Die Aufgaben der Rechtswissenschaft (Rectoral address), Leipzig, 1884, p. 4; also P. Oertmann, Windscheids Gesammelie Reden usw. Leipzig, 1904, p. 102. 


\section{SECTION 3}

\section{THE SCIENCE OF IAW ${ }^{1}$}

Like every other science, the science of law is systematic knowledge. ${ }^{2}$ It is knowledge which binds together into complete unity the objects with which it has to deal, according to their homogeneity, and in which the separate objects of knowledge are apprehended as parts of a whole. This unity, and this apprehension of all single facts as parts of a whole,-in other words, as parts of a system, and of systematic knowledge,are attained by means of definition and classification. By these methodical processes an understanding of the content, and a conception of the whole of the involved facts, are secured. The possibility of collateral and subordinate classifications, and the generalization of all ideas under higher notions, are also realized. This knowledge is systematic, in that all the detailed matter, the separate facts, and single notions, are apprehended and represented as parts of an organic whole. Systematic knowledge of related facts is what constitutes a science.

Fragmentary knowledge is distinguished from scientific or systematic knowledge in this,-that it involves

\footnotetext{
1 Salkowski, Institutionen, Grundzüge des Systems und der Geschichte des römischen Privatrechts, $7 \mathrm{th}$ rev. ed., Leipzig, 1898, sec. 2. [The ninth edition of this highly valuable work appeared in 1907 (Leipzig, Verlag von Bernhard Tauschnitz) edited by $O$. Lenel, who has brought the literary references down to date. Attention may also be called to Mr. Whitfield's translation (1885).] See also Sohm, Institutionen des römischen Rechts sec. 8. [Sohm's Institutes have been translated into English by James Crawford Ledlie, with an interesting introductory essay by Dr. Erwin Grueber.] See also Birkmeyer, Enz., pp. 84, 86-95 (Leonhard).

${ }^{2}$ Compare v. Liszt in Zeitschr. f. d. ges. Strafrechtswissenschaft, Bd. VI, p. 665 .
} 
facts connected together only incidentally, and not according to a relation by which they form a unity of homogeneous parts. Therefore, such isolated facts not bound together by their own coherence, as a system ${ }^{2}$ (which is the attribute of science), form an "aggregate" or a simple cumulation of particulars. As such they are only the preliminary materials of science. As / law is the means of peaceably adjusting the external relations of men and communities among themselves, and to things, so legal science is systematic knowledge of this peaceable adjustment; and all its parts and relations.

All legal rules (commands and prohibitions) are examined, defined, and classified, according to their relations to each other. A system is attained by which legal knowledge becomes a science through the logical generalization of the products of this definition and classification under resulting notions of higher degree. The scientist proceeds from single phenomena which he gathers through experiment or observation, and summing up; and arises to a generic notion, that is, the higher conception,-law, or law of nature,-which is nothing more than the generalization of phenomena under higher conceptions (the inductive method). On the other hand, he may proceed centrifugally, as it were, and draw, or deduce, from the general, from the law, or from the principle, inferences of the particular. The jurist in the same way arranges separate positive rules, and logically derived ideas, inductively and deductively, into a system; and organizes and classifies the facts of life, and the relations of men and communities to and among each other. "The science of law is nothing other

\footnotetext{
1 The dissertation of Julius Jolly, Die Systematik des indischen Rechts, in the Zeitschr. f. vergleichende Rechtswissenschaft, Bd. I, p. 234, is interesting in connection with the gradual growth of classification.
} 
than civilis sapientia, the practical philosophy of civil society. It assuredly does not exhaust itself with the interpretation of a text, nor yet with the formation of legal ideas derived from existing law. Its chiefest function is to discover, and in the highest possible measure securely to establish, the proper legal form of man's social existence adequate to every period of time and every stage of civilization."1

\section{I.-Legal Science as the Science of Positive Law, or Legal Science in the Narrow Sense.}

The jurist as a scientific investigator no more creates the objects of his scientific knowledge than the naturalist produces phenomena and laws. Both find their material existent in the external world. The objects of the science of law as a positive science-the science of positive law, -are derived from legislation ${ }^{2}$ and custom; as the objects of natural science are created by nature; and as the facts of the history of art are created by the arts.

Legal science has for its province the derivation of ideas out of the materials provided by legislation and custom, and their arrangement and classification. By this method the law is reduced to a system and its knowledge becomes systematic knowledge. ${ }^{*}$ This process is necessary in order to learn the range and meaning of each particular legal principle (that is, each legislative rule, or rule of customary law and its legal consequences) and to apprehend the relation of one legal principle to another.

${ }^{1}$ Goldschmidt, in the Zeitschr. f. H.R., Bd. 35 (1888), p. 11 .

${ }^{2}$ See below, Sec. 11.

${ }^{3}$ See below, Sec. 10.

${ }^{4}$ Compare v. Liszt, loc. cit., 666 . See note 2, p. 13 , supra. 
In so far as legal science accomplishes this, it tends toward and attains its theoretical object. Like every other science, the science of law is in the first degree an object in itself. It is an impulse of the human mind , to know the knowable, so far as possible, even though it be recognized that a full apprehension of all things, and particularly the highest things, is not within the province of human understanding. ${ }^{1}$ This impulse toward knowledge corresponds to the sense for truth, the ethical tendency leading to the true. The pursuit of this tendency, the realization of this sense, and the satisfaction of this inclination are not objects of curiosity, or pleasure, but are direct impulses toward civilization and the attainment of an expression in mankind of the most important attributes of human nature.

Legal science pursues two practical ends alongside of this theoretical design. "We know that the science of law has for its purpose a contribution to an existence and expression of law which will satisfy human interests and necessities as they appear here and now. It is delightful to soar in the ether of pure reason; but it is better to labor for the welfare of mankind."2 This practical labor which Windscheid indicates includes:-

1. The furtherance of the administration of existing law; and

2. Co-operation in the making of new law.

Law and its administration are necessary to make possible the social life of man and a common effort toward social progress. For the thorough maintenance and observance of the law, within and without the courts, the range and meaning of each legal principle must be apprehended to the fullest extent. To secure the proper application of the law, it is indispensably

\footnotetext{
${ }^{1}$ The generalizing impulse goes further than this. See Religion, below,
} Sec. 6, p. 42.

2 Windscheid, op. cit., p. 9. 
necessary to attain a precise knowledge and description of its whole theoretical content. Only by this accomplishment is possible any reconstruction of legislative ideas. Without this knowledge there can be no adequate expression of legislative purpose or any understanding of the meaning of principles of customary law. ${ }^{1}$ If in the making of new law numerous ethical and economic considerations, and also allowances of pure convenience, must be entertained, yet the knowledge of the existing law, whether here or elsewhere, will not be idle.

The scope of that part of legal science which is called the dogmatic of the law, or dogmatic legal science, is the formulation of a system of legal science by means of definition and division, and a classification into this system of existing legal principles found in the positive law (legislation and custom) of a particular state, or one or more divisions of a state, or a plurality of states. It arranges the positive materials of the law in systematically ordered and organized propositions, or dogmata.

In so far as it is the object of legal science to ascertain the genesis of existing law, its evolution through its causes, influences, phases, and epochs, and from this material, to develop the sense and meaning of particular legal principles, it becomes "historical legal science," or legal history.

Although, as a matter of course, an academic and literary exposition may be separately made of the history of the positive law of every state, of every people, and of every stage of development, yet there is not to be perceived any essential opposition between legal history on one hand and dogmatic law on the other, or legal science in general. The historical consideration and investigation of the genesis of a legal

1 Compare the relevant passages in Windscheid, op. cit., pp. 10-14, 18, 19. See infra, Sec. 12, 13. 
principle are rather an indispensable auxiliary to an interpretation of dogmatic law.

\section{II.-Natural Law, Philosophy of Law, and Legal Science."}

Natural law, the law of reason, or jus naturale, is understood in various senses.

The usage of the Roman jurists implicated under jus naturale elements which lay entirely outside of the domain of law and belonged to the sphere of ethics. ${ }^{2}$ In part it embraced also such legal principles as, by reason of their having a more universal and unlimited scope than the so-called $j u s$ civile of the Roman Quirites, were contrasted with ancient Roman civil law in its narrow sense, and were regarded as a part of the jus gentium. ${ }^{3}$

The doctrine of the seventeenth century ${ }^{4}$ annexed to the ancient notions, a law of nature (Naturrecht) based on religious ideas, which was to be a system of universally valid and unchangeable legal principles. $^{5}$ This view reached its climax and greatest influence ${ }^{\circ}$ in the eighteenth century, although it still found adherents in

'Salkowski, Inst., p. 3: J. Kohler, in K. u. v. Holtz. Enz. I, pp. 3-20.

2 Jus naturale est, quod natura omnia animalia docuit, nam jus istud non humani generis proprium est, sed omsium animalium, quae in coelo, quae in terra, quae in mari naseuntur; hine descendit maris atque feminae coniugatio. quam nos matrimonium appellamus, hine liberorum procreatio et educatio: videmus etenim cetera quoque animalia istius iuris peritia censeri. Inst. 1, 2, pr.

3 Jus gentium does not mean international law (jus inter civitates) in the technical sense (see below, Sec. 54), but general civil law. Compare Inst. 1, 1, 2: Quod vero naturalis ratio inter omnes homines constituit, id apud omres populos peraeque custoditur vocaturque jus gentium, quasi juo jure omnes gentes utuntur.

- Concerning Hugo Grotius and his followers see Gareis, Institutionen des Völkerrechts, sec. 5 .

${ }^{5}$ Chancellor v. Kreittmayr, the author of the Bavarian Landrecht of 1756. says in the notes thereto $(1,2,4,4)$ : "There resides in the laws of nature the peculiar attribute of unchangeability. God himself can not alter them."

- Compare, O. Gierke, Naturrecht und Deutsches Recht (Rectoral address), 1883. 
the nineteenth century. ${ }^{1}$ It was overthrown, or at least pushed into the background, ${ }^{2}$ by the historical conception $^{3}$ of the nature and genesis of law.

The hypothesis of an universal, unchangeable law stands, as an ideality, in opposition to the necessity of a conformability of law, corresponding to the demands of the age and the state of culture of a people. ${ }^{4}$ An

1 Compare W. Snell, Naturrecht, Vorlesungen, 1857; A. Trendelenburg, Naturrecht auf dem Grunde der Ethik, 1857; in particular, however, H. Ahrens, Naturrecht oder Philosophie des Rechts und des Staats, 6th ed., 1870. [This celebrated work of Ahrens appeared In French under the title Cours de droit naturel. Translations have been made from the French into Italian, Spanish, Portuguese, and Hungarian. The author states in the preface to the sixth German edition that up to 1869 twenty editions of the work had been published in the various languages. No translation of this work has ever appeared in English. As perhaps one of the most representative monuments of the Naturrecht standpoint, this work would no doubt prove to be of peculiar interest to American readers in view of the remarkable position which the natural-law conception has attained in political thought and as reflected in judicial speech. It is still very common to find references to "natural justice" and similar phrases, especially when there is room for any arbitrium judicis. See also Lorimer, The Institutes of Law, a Treatise of the Principles of Jurisprudence as determined by Nature; Taylor, Elements of Civil Law: Smith, The Law of Private Right; Hastie, Outlines of Jurisprudence; Lioy, Philosophy of Law, translated into English by W. Hastie; W. S. Pattee, The Essential Nature of Law, or the Ethical Basis of Iurisprudence (Callaghan \& Co., Chicago, 1909); Locke, Civil Government; Spencer, Social Statics; Spencer, The Man versus the State; James Schouler, Ideals of the Republic (Little, Brown \& Co., Boston, 1908).] In opposition, see F. Dahn, Rechtsphilosophische Studien (Berlin, 1883), p. 144. Compare Kohler, in K. u. v. Holtz. Enz. I, p. 4, note 2.

${ }^{2}$ Compare Bekker, Ueber den Streit der historischen und philosophischen Rechtsschule, Academic address, 1886.

${ }^{3}$ Savigny, Vom Beruf unserer Zeit für Gesetzgebung und Rechtswissenschaft, Heidelburg, 1814.

4 "It is an ancient, never-ending dream of mankind that there is a peculiar, rigid and unchangeable law. This law is thought to be a law of reason. What is agreeable to the reason is supposed on that account to be law, and necessary for all times, and in all places. This view is not that alone of the lay public. It is also recognized in the manner in which it has ruled over science. It is now regarded by science as error; but it has not been completely eradicated. There exists only the reason of the individual man, who indeed learns with difficulty not to take his reason for the reason. This holds for all departments of human knowledge. It is true also of legal knowledge." -Windscheid, Rectoral address, p. 7. See also Oertmann, op. cit., p. 105. The distinction between lex naturalis, as human law, and lex ceterna, as an immutable law of nature, was made by Thomas Aquinas, and further by his pupil Dante (de monarchia I, 16), on which Kohler comments, Rechtsphilosophie, in K. u. v. Holtz. Enz., I, p. 3. 
unchangeable law would presuppose a stable and universally similar state of civilization and similar conditions of necessity in mankind. The idea of law involves variation, in that it must be conformable to the conditions of civilized life, on account of which it is created and exists. The protection of the various interests of life which law is intended to shield will not be everywhere and at all times best and most securely fostered by the same means. It results, therefore, as must be the case, that the commands and prohibitions created by a legal system must vary, the more as economic views and necessities change, and as the influence of custom, and morals, varies. Thus the idea of ownership was one thing in Rome and another in Germany. Controversies exist as to the dissolubility of the marriage tie; concerning constitutional, parliamentary, and absolute government; the death penalty; solitary confinement; state operation or control and economic individuality; and bureaucratic and popular courts. Countless questions relating to constitutional, administrative, and private law required a different answer a thousand years ago than today; and these questions must be answered differently in England than in Germany, and again differently in North America than in China or Samoa.

This demonstrated impracticability of natural law, or the law of reason, however humane, beneficent, and ideal from the subjective standpoint, shows that in the regulation of the external relations of mankind an outwardly sustained authority, and proceeding from this authority, a positive law suited to the time, the place, the people, and the state of culture,-an historically acceptable and historically refined law,--alone is serviceable.

This rejection of an asserted law of nature, or law 
of reason, does not in any sense imply a renunciation of a philosophy of law. Philosophy of law has for its object to investigate the basis of the legal structure, and to develop the necessity and the nature of legal standards from the nature and history of mankind. It has no concern, however, with the legal standards themselves. It is the science of the nature of law, its premises, its sources, its evolution, and its social importance. It seeks to know the objective principles of all legal systems and legal development. It exerts itself to discover (but not to create) the whole positive basis existing legal standards considered as historical and mutable forms. It regards these standards as historical variations of legal systems ${ }^{1}$ apart from any arbitrary assertion of ideality. It must be stated with regret that, until the most recent times, treatises on natural law and on philosophy of law have frequently confused the two; and it must be recognized as a service rendered by Kant to legal science that he distinguished natural law from the science of law by limiting himself to the philosophical consideration of law. ${ }^{2}$

\section{III.-Politics and Legal Science.}

Politics (Politik) is an activity or art dealing with the knowledge of concrete governmental problems and their solution through the exercise of governmental methods,the art of government. Considered as a science, politics is systematic knowledge of the functions of a concrete ${ }^{3}$

1 E. J. Bekker is fully in accord when he says, in opposition to Bierling's highly ideal but ethico-natural position: "The philosophical department of legal science goes no further than the legal idea or to legal ideas, in the discovery of which the comparison of the most diverse legal systems is indispensable."-Zeitschr. f. vergleichende Rechtswissenschaft, Bd. I, p. 100.

${ }^{2}$ Compare E. Landsberg, Geschichte der deutschen Rechtswissenschaft, $\mathrm{Hb}$. Bd. I, Abt. 3, p. 503 (1898).

${ }^{3}$ This does not include the notion of the state itself. Another science, the science of the state (staatswissenschaft), is concerned with the abstract 
state, and the ways and means of their execution. Politics is related to law in a double aspect; it is at once an object and a means of law. It is an object of the law, in that the development of public and private law is the function of every state. Accordingly the political aspect of law $^{2}$ forms a part of a legislative and administrative polity ${ }^{2}$ which the state must pursue guided by considerations of expediency,-considerations de lege ferenda. It is a means of the law, in that legal rulesas for example, threats of punishment, prohibitions and commands-are furthered by politics in the attainment of the objects of economic, military, fiscal and other branches of polity of the state. Legal science, therefore, comes in contact with politics without either being a part of the other; and legal science ${ }^{3}$ is of assistance to politics in so far as it concerns itself with legislative development.

problems of the state and their solution-that is to say, the science of the state in general, its universal nature, its ends, etc. [The science of the state, which is one of numerous departments of political science, is also called abstract politics; see Century Dict., sub voce. Politics]. See Gareis, Das allgemeine Staatsrecht, in Marquardsens Hdbch. d. off. Rechts, Bd. I, pp. 16, 17.

1 Rechtspolitik.

2 Gesetrgebungs- und Verwaltungspolitik.

${ }^{3}$ [The Germans classify Science of Law (Rechtswissenschaft) in to Jurisprudence, on one side, and Philosophy of Law, on the other. In this scheme, Jurisprudence embraces the concrete elements of law, while Philosophy of Law deals with its abstract and fundamental side. It is accordingly possible for German writers to consider Jurisprudence not strictly as a science of universal principles, but as something limited by time or place. They may therefore speak freely of a Jurisprudence of modern times, or the Jurisprudence of a particular state. (See Sternberg, Allgemeine Rechtslehre, Part First, pp. 123, 153; also, the diagram definitions of Friedrich (Die Bestrafung der Motive und die Motive der Bestrafung. 1910) in Archiv fur Rechts und Wirtschaftsphilosophie, Bd. III, 2, 201.) This is the usage of the European continent, and especially of France, where Jurisprudence is practically synonymous with case-law. It has also found a wide reception in our language.

Austin distinguished General Jurisprudence and Particular Jurisprudence, making General Jurisprudence synonymous with Philosophy of Law (socalled), and leaving Particular Jurisprudence to cover the remaining practical field of the law local to each state. In this connection it is obvious, of course, as has often been remarked, that if Jurisprudence is a science it can hardly be localized as such. 
Salmond (Jurisprudence, 2d ed., London, 1907) has adopted the primary classification: Theoretical Jurisprudence and Practical Jurisprudence. This solution is not an improvement.

Holland (Elements of Jurisprudence), who has rendered our juristic terminology much valuable service, insists on the scientific character of this study. and says (p. 5): "The imposing quadrisyllable is constantly introduced into a phrase on grounds of euphony alone." It may be, however, that this solecism has fastened itself so tenaciously on our language that it may not be possible to restrict Jurisprudence to the abstract side of the law, especially in view of its practically world-wide technical and popular use in a concrete sense.

The German use of Philosophy of Law (adopted by Austin) is also subject to criticism. It subordinates philosophy to science, and in this conflicts with the established conception of the related provinces of science and philosophy. The use of the term "philosophy" in this connection is meaningless except so far as it implies the essential attribute of generalization characteristic of philosophy. It assimilates a colloquialism which permits philosophy to be used in a sense synonymous with process, method, arrangement, reason, etc., and even as expressive of a state or habit of mind. Logamachy is, always has been and always will be a necessary evil; and perhaps the only true guide is relative convenience. Technical refinement and etymology are frequently overridden.

While it is no doubt true that words are only labels for ideas, it is very desirable to employ labels that are consistent with themselves in other applications.

It is highly necessary that the divisions of legal study be ascertained. The following classification, which ignores the conflicts above indicated, is suggested:-

The Science of Law may be divided into a General Part and a Special Part.

(I) The General Part will include the absolute, theoretical, formal, abstract and universal side of the conception of law. It will include that which should be properly denominated Jurisprudence and which is variously called Philosophy of Law, General Jurisprudence and Theoretical Jurisprudence.

(II) The Special Part will include all that is relative, practical, substantive, concrete and local in the law. It is that part which is now so frequently associated with the term "Jurisprudence," as Particular Jurisprudence, Practical Jurisprudence, etc. (for example, "Anglo-American Jurisprudence," the "Jurisprudence of the United States Supreme Court," etc.).

(I) The General Part of the Science of Law may be subdivided as follows:-

1. The theory of law; its origin, nature, functions and purposes.

2. The history of jural ideas, including history of the schools of jurisprudence.

3. Juristic Survey. Juristic Survey may be again divided into the following groups:-

(a) Analysis;

(b) Synthesis;

(c) Classification.

(II) The Special Part of the Science of Law may be divided into the following groups:-

1. Administration of justice; law in its practical and concrete application.

2. History of law and legal evolution; dealing with the history of legal ideas in their practical and material sense. 
3. System of law (the corpus juris). The system of law may be divided in to the following groups:-

(a) Commentary (exposition):

(b) Criticism (censorial);

(c) Divisions (classification).

It will be noted that the divisions on either side of the general and special parts of the Science of $\mathrm{Law}$ are systematically contrasted. Treatises in either department of the Science of $\mathbf{L a w}$ do not confine themselves strictly as a rule to these divisions. For example, in the General Part of legal science treatises may and usually do deal with legal theory, legal history and juristic survey at the same time. The character of the work is to be determined by the predominant division of treatment. It is the same with works in the Special Part of the Science of Law, which may deal concursently with commentary. legal history and legal criticism. It will perhaps be understood without further explanation that the expressions "General Part" and "Special Part" are not here suggested as substitutes for terms now employed. It is very probable that the German usage will prevail. 


\title{
SECTION 4
}

\section{CONTENT OF JURISTIC SURVEY}

\author{
Juristic Encyclopedia ${ }^{1}$
}

\section{Encyclopedia means a circle of related subjects,} parts or departments belonging to a certain science, or to all sciences. It is a systematic survey of the objects of study, - a panoramic, unified exposition of a science,through which a comprehensive, epitomized knowledge

${ }^{1}$ [Rechtsenzyklopadie. There is a singular poverty of this class of works in the English language. Of juristic investigation (as opposed to legal discussion) there is none, or practically none. since efforts in this direction have been of very limited expression, and have failed so far to exert any appreciable influence on the professional mind anywhere in the domain of the English law. Except to a small circle of students who may have read Mr. Hastie's fragmentary translations of Falck and others (and have read, perhaps, with little profit), and except to a limited few acquainted with the German material, Juristic Survey is an unknown quantity; and the more comprehensive term Jurisprudence, itself, may hardly be said to have among us a clearly defined status of usage. Its position as a separate science is little better established now than at the time when Austin waged an extraordinary battle with legal empiricism, memorable for intellectual illumination but melancholy in result. To the legal profession, Jurisprudence and Pkilosophy of Law are little more than sounds, with an indefinite combination of shifting mental overtones. To the law school, which since 1870 has assumed in America a leading position in legal education, they are inhospitable uncertainties, unjustified disturbers of legal practicality, and things to be regarded with suspicion.

The English law is submerged in an ocean of particular cases, in which flow no guiding currents, but which rather is agitated by variable winds. If any leading principle is to be extracted from this multiplicity, it may be said to be that of individualism, which now is gradually being broken down by the invading processes of judicial legislation in favor of social welfare. In that part of the legal domain which may be influenced by considerations of social ends, there is less need and smaller possibility of authoritative reconcilement of these judicial conflicts than in that wider range of individual and social activity in which the kind of regulation is a matter of indifference, but the certainty of the rule is paramountly necessary. The former legal activities are the proper subject of social, ethical and economic evolution and are not a matter of definite arbitrament for all ages; the latter, however, peculiarly exhibit, in the vast multiplication of our case law, the burden (not much longer to be endured) of a disorganization and a strife which can only be set 
indispensably necessary in the pursuit of a science in detail, is acquired. ${ }^{1}$

Juristic encyclopedia, accordingly, is a systematic, unified survey of the means of peaceable adjustment of the external relations of mankind and social communities. In the attainment of its ends, it is necessary that an encyclopedic exposition be systematic in method. It starts from a central legal notion and its development, to which constant recurrence is had. By this method the individual subjects or departments of the law (as, for example, criminal law, the law of bills of exchange, or administrative law) are exhibited as branches of the law; and the relation as well as the line of demarcation of the separate parts of legal science is shown. In the survey of the whole, in the centre of which lies the notion of law, the dependent parts must be so delineated that the periphery of the circle is indicated by the central notion, from which a delimitation of law from the cognate departments of morals, religion, etc., will appear.

Although the scope of Juristic Survey thus separates it in its objects and nature from cognate studies, yet its content is such that it admits of differences in

aside by an exaltation of that neglected study of the form of the law without which no enduring reform can be accomplished.

Of the works most nearly corresponding in our language to the Juristic Survey of the Germans, see Salmond. Jurisprudence, 2d ed., London, 1907: Austin, Lectures on Jurisprudence, or the Philosophy of Positive Law; Terry, Leading Principles of Anglo-American Law (T. \& J. W. Johnson \& Co., Philadelphia, 1884); Holland, Elements of Jurisprudence, 10th ed., 1906: Markby, Elements of Law, 6th ed., 1905.]

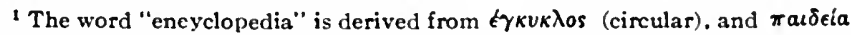
(instruction, discipline). The modern usage of the expression, the principles of which were already applied by the Greeks to indicate the same thing (see Quintilian, Inst. orat. I, 10,1), was derived from France in the middle of the eighteenth century. (The manifest difficulty of the use of this term in this connection in our language is that it will be associated with such works as the Encyclopedia of Law, and other similar compilations of extensive bulk, based on an alphabetical arrangement and not on an internal rclation of subject-matter, which by reason of their wide use in the legal profession have established in the popular mind notions difficult to reconcile with the limited bulk and the systematic arrangement of a Juristic Survey.] 
method. It may be, first, quantitatively different. It may embrace the law of a particular state, at a particular time, etc.; or it may embrace the law of various civilized states, etc. Again, it may present qualitative differences, and be formal ${ }^{1}$ or external. In this aspect it may deal solely with particular legal studies and divisions of the law, but not with existing legal rules, commands and prohibitions in their application; or it may be material ${ }^{2}$ or internal-that is, dealing dogmatically with established legal rules applicable to the framework or structure of the law.

The present work seeks first to be formal, although the framework is supplemented by suggestions of legal rules as far as this is necessary for the fullest attainment of the objects pointed out at the beginning.

The literature of Juristic Survey is amply indicated in the following works, which are named in preference to numerous older books:-

1. A. Friedländer, Juristische Enzyklopädie, Heidelberg, 1847. (Extensive notes on the literature, pp. 9-42.)

2. L. Goldschmidt, Enzyklopädie der Rechtswissenschaft im Grundriss, Heidelberg, 1862. (Literature, pp. 4-6.)

3. L. Arndts von Arnesberg, Juristische Enzyklopädie und Methodologie, 10th edition of Erwin Grueber, Stuttgart, 1901. (Literature, pp. 7-9.)

4. A Merkel, Juristiche Enzyklopädie, 2d edition prepared after the death of the author by R. Merkel;

\footnotetext{
1 The Juristic Survey (encyclopedia) of Arndts von Arnesberg (99 pages) is an example of this class.

${ }^{2}$ For example: v. Holtzendorff, Enzyklopādie der Rechtswissenschaft, 6th rev. ed., edited by J. Kohler, 1904; also Birkmeyer, Enzyklopädie der Rechtswissenschaft, written by A. Arndt, F Bernhöft, K. Birkmeyer, E. Grueber, Fr. Hellmann, P. Hinschius, H. O. Lehmann, F. Leonhard, K. v. Lilienthal, F. v. Liszt and Fr. Stein. (2d ed., Berlin, O. Häring, 1904.)
} 
3d edition, 1904, Berlin (J. Guttentag, Ges. m. b. H.). (Literature, pp. 10-21.)

None of these lists contains J. Kohler, Einführung in die Rechtswissenschaft, Leipzig, A. Deichert, 1902. [2d revised and enlarged edition, 1905. See also Kohler, Lehrbuch der Rechtsphilosophie (.Verlages Dr. Walther Rothschild, Berlin, 1909).] 


\section{PART FIRST}

\section{LAW .AND ITS SOURCES}

\section{SECTION 5}

\section{LAW IN GENERAL}

Law is the (means of) peaceable regulation of the external relations of persons and their social communities among themselves. It is a regulation (norma agendi), adjusting or standardizing through commands and prohibitions. Its object is the adjustment of the external relations of mankind and social communities. It does not concern itself with internal activities which belong to the domain of morals or religion. ${ }^{1}$ Its end and purpose is such a method of influencing these relations by commands and prohibitions that it may be justly called peaceable regulation. It may involve, though not by necessity, measures of coercion. It is denominated peaceable regulation even though there be a possibility

\footnotetext{
${ }^{1}$ Regarding the notion "law," see E. J. Bekker in the Zeitschr. f.vergl. Rechtswissenschaft, Bd. I, p. 95; also Felix Dahn, ibid., Bd. III, p. 8. Concerning the term "law," see the article "Recht" by Moritz Heyne in J. and W. Grimms" Deutsches Wörterbuch, Bd. VIII, serials 2 and 3 (1886-87), columns 364-406, and particularly column 442; and also Kluge (Jena) in v. Kirchenheim's Zentralblatt für Rechtswissenschaft, Bd. VII, p. 377 (1888). On the derivation of "Recht," see K. von Amira, Grundriss des Germanischen Rechts, which is a separate reprint from Paul's Grundriss der Germanischen Philologie, $2 d$ ed., sec. 4, p. 7 (1901).

[The author's definition of law is: Das Recht (i.objekt. S.) ist die Friedensordnung der äusseren Beziehungen der Menschen und ihrer Gemeinwesen iuntereinander. It will be observed that a slight liberty has been taken in the translation of this definition. Law may be considered either as a means or as a result. Friedensordnung in like manner is ambiguous. The liberty taken by the translator is, however, only verbal, since the context clearly indicates that the means and not the result is intended.]
} 
and even a necessity of the maintenance of legal order, in the extremest cases, by supreme force, as in the event of insurrection, or war. It is therefore peaceable regulation, inasmuch as its means (i.e., commands and prohibitions) are first of all peaceable, and as the establishment and maintenance of peace and tranquillity are the conditions $^{1}$ necessary to a development of human powers, and the progress of civilization.

Though this peaceable regulation be described as conformable to reason, one must not by any means regard the particular rules of this peaceable regulation as based on reason, and take a natural-law viewpoint. Assertion can go no further than that this peaceable regulation, considered in the abstract,-the existence of law as such,-whether appearing as command or prohibition, is a postulate of human thought and human nature, derived from the external necessities of life, from human reason and from the legal and social sense.

The relations which constitute the object of this regulation are relations of individual persons among themselves, as well as relations of communities of persons (so far as these communities have interests which are different from those of individuals or natural persons).

If it be added, that there are also relations with reference to things and to property as means for the satisfaction of necessities, then this addition serves for illustration of the definition but not for its completion; inasmuch, as commands and prohibitions which legal order employs, and by which it is established, operate, as is self-evident, only against persons. The interferences with and dangers to peace and security, against which legal order operates, are thinkable only as acts, positive or negative, against persons, or the community. It is

\footnotetext{
infra.

' For the literature of this much-controverted notion see note $1, p .33$,
} 
true that things have relation, but for the purposes of law these relations are of secondary importance. Commands and prohibitions can not operate against things, but only on human will.

Commands and prohibitions create limitations on the scope of the will. Through this limitation, persons and social communities attain, as a product of law, rights (facultas agendi, powers, titles).

The nature of a legal right is such that it is always a definite interest, actually entertained by a person or a community. For the protection and guaranty of these interests, legal order expresses its commands and prohibitions, and through this guaranty interests become legal interests (legal rights). ${ }^{1}$

Interests, considered as facts, arise directly from egoism, and are nothing other than subjectively perceived relations $^{2}$ (derived from necessity), between the person feeling the necessity, and an object; that is, the object for which the recessity exists and is felt, and through which, by use or consumption, the necessity, actually or

1 The expression "legal relation" (Rechtsverhälnis) means such a relation as is governed by legal order. According to Windscheid, there are not only such legal relations as are governed by legal order, but also such as are created by it. See Windscheid, Pand., sec. 37 . It would appear, however, that there can be no legal relation which is not at the same time based on a condition or relation of fact, inasmuch as there are no interests which are first created by legal order and which did not already exist in fact. There are no legal relations without interests. The expression "case" (in law) (Rechtsfall) means a concrete legal relation between a definite subject and object. "Legal institution" (Rechtsinstitut) means the totality of rules which elevate a condition of fact to a legal relation, as a theoretically derived abstraction. Thus one speaks of the legal institution of marriage, by which is meant the totality of rules through which the actual conditions of interest which lie at the basis of wedlock attain legal protection-that is to say, become legal relations. Compare Windscheid, Pand, sec. 37.

2 Beziehung (relation) is derived from "sich beziehen" (to draw, refer or relate to) and means, to perceive oneself in a certain relation to an objectthat is to say, the bearing or position to the object made use of. The same thing is indicated by the word Verhaltnis (connection), to show the means or method by which a person or thing is related to another,-by application, enjoyment, use, service, etc. Compare Weigand, Wörterbuch, sub voce Verhalten. 
probably, will or may be satisfied, in whole or in part. Thus the fecling of want, called hunger, is a vital interest of a person in the food within his reach; and the sensation of cold evokes a vital interest in the cloak before him.

It is self-evident that the hungry person can enjoy his food without the existence of legal order, and the cloak will give its warmth even though no legal rules grant its use. Interests may exist even without law, and, moreover, many such interests are beyond the compass of legal protection. The interest that man has in the coming and going of the years, in the weather, the friendly esteem and thought of his neighbors, in the beauty of the sunrise, and the stellar firmament,-all such interests are beyond the protection of the legislator, as much as they are beyond his creation. They are created by the conditions of life, and the living satisfy these interests in so far as necessities are actually gratified. Legal order, however, provides by prohibitions that the actual satisfaction of these interests shall not be interfered with by others.

Where co-operation of others is actually necessary to the satisfaction of a necessity in a protected interest, it provides by commands that this co-operation shall follow. Legal order says to the hungry person, "No one shall interfere with you in the enjoyment of your food," and, as we express it, protects and guarantees to him the interest which he has in the food. It says to the man who feels the cold, "No one shall take your cloak," and protects, by prohibition, the interest which he has in the garment. The man who advances 100 marks to another in a time of need naturally has an interest in receiving a return of the money, when the time for payment has arrived. Legal order protects this interest, in that it gives to the lender a right of action for recovery, and commands the borrower to 
repay the money. In that legal order cominands the conjugal duty of married persons, and prohibits sexual relations with third persons, it protects by command and prohibition the interest of conjugal affection.

Relations or interests are not created by commands and prohibitions (or, in a word, by a rule of law) any more than a garden wall makes a garden. The interest is simply limited by the rule, within which limits it is protected and guaranteed, and outside of which it is not guaranteed or protected. The perpetual controversy whether law protects interests as such, or only the will to have the object of the interest, may be answered in this way: The protection of the will is a means, and, indeed, as it is protection afforded by a rule, is the characteristic instrument of the law for the protection of interests. Interests, however, are the essence of legal rights. Just as the space inclosed and protected by a garden wall can not be deprived of its character as space by the wall, so also in "protected interests" the interest does not cease to exist by withdrawing the protection. ${ }^{1}$

${ }^{1}$ With reference to these important controverted questions, the answer to which has created a profound conflict in modern legal science, the pertinent matter is found in the writings of Binding. Brinz, v. Ihering, Kohler, v. Liszt, Seydel, Thon and Windscheid. Compare Binding, Die Normen und ihre Ubertretung, Leipzig, 1872, 1877, and Handbuch des Strafrechts, Leipzig. 1885, sec. 30; v. Brinz, Pandekten, secs. 18, 123; v. Ihering, Zweck im Recht, 1st ed., Bd. I, p. 321; Kohler, Patentrecht, p. 500, and "Recht und Prozess" in Grünhut's Zeitschr. f. Prival- $u$. offentl. R. d. Gegenwart, Bd. XIV, p. 1; v. Liszt, Lehrbuch des Strafrechts (1884), sec. 85, and Zeitschr. f. d. gesamte Strafrechtswissenschaft, Bd. VI, p. 664; Thon, Rechtsnorm und subjektives Recht, Weimar, 1878; Windscheid, Pand., secs. 37, 38, and also his Rectoral address 1884 (supra), particularly p. 5. This matter is treated more in detail in the following writings of the author, as follows: "Die Privatrechtssphären im modernen Kulturstaat," in Hartmann's Zeitschr. f. d. öffentl. Recht, Bd. III, p. 137 (1877); "Das juristische Wesen der Autorrechte," in Busch, Arch. f. Theorie und Praxis des a. d. Handels- und Wechselrechts, Bd. 35, p. 185 et seq., particularly pp. 195, 200 (1877); Allgemeines Staatsrecht, in Marquardsen's Handbuch des offentl. Rechts, Bd. I, sec. 1 (1883), in which the author endeavored to construct public as well as private law on the above theory of "protected interests." 
As against third persons who are prohibited by rule from interfering with an interest, or who are commanded to carry out an interest of another by acting affirmatively, there appears an act of the will. The performance of this act permitted by law becomes a protected interest to such an extent that the person ${ }^{1}$ so protected is allowed legally to carry out his interest by his will, even against the will of another. This view legitimately requires that a "protected interest" be designated as a faculty, power, or facultas agendi, and accordingly that rights be defined as above shown.

The real nature of protected interests is not expressed by making prominent the element of legal permission to act. One may will that which he can not legally accomplish by force of law. ${ }^{2}$ That which may be effec-

1 Interessenträger.

2 A manufacturer may certainly require of his employees labor in excess of his contract of employment, the factory regulations, etc. He may demand it, that is, he may will it, and may exert his will. Such demand is not prohibited, and he has perhaps also an active interest in such overwork. The question is, Will the employees perform what they are not legally bound to do? They may so perform, and the employer makes a not purposeless use of his power, in that he reckons on it that necessity, the fear of poverty, and similar motives, will prevail to occasion the extra service. Therefore the employer has the liberty to will and an interest in, but not a right to, extra service, if the law-that is, the standard-does not guarantee his interest through a command on the employee. That which is not prohibited, such as a liberty, is not, therefore, in itself a right. A liberty does not become a right until it and the interest involved therein are guaranteed by legal standard-that is, by means of command or prohibition, or both.

In that interests are designated as being the substance of rights, it is necessary to observe that it is possible to consider a double interest. or interests regarded from two sides. Accordingly one may say: (1) The subject has an interest in an object which is denoted to the faculties of perception as belonging essentially to the satisfaction of a want; as, for example, a hungry person has an interest in a loaf of bread; a person suffering with cold has an interest in a cloak; and the employer has an interest in the performance of the labor of his employees; (2) the subject has an interest only in the undisturbed exercise of his will, and consequently the object of the interest would be always a relation to persons, and having an importance in that the act of will directed to the object of the necessity, as the eating of bread, the wearing of the cloak, or the employment of labor, is not interfered with.

The last notion might upon first impression appear the corsect juristic conception, but the correction would be empty of content and lead to pure 
tually willed is a legally guaranteed interest. It is also called "legal advantage" (Rechtsgut), a term which is employed as well to designate the interest (in the sense indicated) as the object of the interest. It may also be employed in the abstract as well as the concrete sense. For example, one may speak of the legal advantage of ownership, which is the abstract usage; or of a concrete legal advantage, as in the case of a protected interest of a definite person in a definite object. The legal protection afforded by the law, or norma agendi, is therefore the protection of legal advantages. Interests become legal interests, legal advantages, or rights, through this protection, based on commands and prohibitions.

Nirvana. Not even the Indian pillar-saint has only an interest not to be disturbed, but has positive ends peculiar to himself. A sleeping person has not only an interest not to be disturbed in his sleep, but also a positive interest to find refreshment in sleep. In rights, also, we may truly recognize a practical content: the interest in those objects which are the means of the satisfaction of wants, i.e., movable and immovable things, co-operation by word and deed, etc. Accordingly we must consider corporeal things (Güter) in an economic sense, and interests in the first sense pointed out above, and seek to classify rights according to the difference of these objects. See below, sec. 14. See also Binding, Hdbch. d. Strafrechts, sec. 30 , note 8. 


\section{LAW COMPARED WITH MORALS, RELIGION, EQUITY AND SOCIAL CONVENTION:}

There is a similarity in these five ideas, in that rules for human conduct ${ }^{2}$ flow from them. In certain stages in the progress of civilization, the difference in the sources of these rules has been overlooked and misunderstood. Legal rules have been confused with moral and religious commands. ${ }^{3}$ This confusion has often

2 Compare Bernhöft, in Zeitschr. f. vergleich. Rechtswissenschaft, Bd. II. p. 253: F. Dahn, ibid., Bd. III, p. 8.

2 "A thousandth part only of our lives pertains to the laws; the remainder is governed by custom and the opinion of society."-Leo N. Tolstoi (Luzerne. Ausgabe Reclam Nr. 1657, p. 37). This point is made by Kohler in Shakespeare vo dem Forum der Jurisprudenz (1883), p. 71, note 3. Our actions are guided by rules of law, morals, religion, justice and social convention, but frequently also by entirely different things, as opportunism, scientific. technical and economic considerations, feeling, etc. The last motives of conduct are not rules. So far as they may not be considered as emanating from the sources above mentioned, they do not enter as binding authoritatively on the will, and in themselves they do not exhibit duties. There may. however, lie a violation of legal, moral or other duty in the disregard of a rule considered from a scientific or technical standpoint, as, for example. the disregard of a rule of medical practice.

3 Failure to discriminate between the different kinds of rules is an ancient error and one arising from various causes. Even the Decalogue (Mos. I, cap. 20), which is, as said by v. Holtzendorff ( Hdbch. d. Volkerrechts, Bd. I, p. 196), "the fundamental document of the civilized world, the most universal and most accepted standard of human duty, and the basis of the morally practical education of nations; magnificent in its simple, uninvolved brevity," contains at once legal, moral and religious rules. In fact, the whole Mosaic legislation embraced all manner of rules governing clothing, food, medicine, building, festivals and other regulations of a religious, juridical, moral and police character. Similar lack of discrimination is to be found in the ancient Indian law, in Manu, Yajnavalkya and Narada; concerning which compare in particular Julius Jolly, Recht und Sitte, in Georg Būhler's Grundriss der indo-arischen Philologie und Altertumskunde, Bd. II, Heft 8, p. 1 (Strasburg. 1896). The code of Manu, which expressly points out that it is a means of eternal bliss, and establishes for mankind a theory of eudcemonism, contains not only its eighteen categories of law, but also manifold rules of morals and deportment, political counsels, etc. Thus the laws of Manu elevate the requirements of deportment to a level of juridical commands. The bearing 
been a matter of great consequence to humanity. While the correlation of these five sources of rules, among themselves and with the unity of civilization, is not to be ignored, ${ }^{1}$ yet their logical distinction must be determined, in order to establish the limits of the notion of law, as opposed to related provinces, and in order to arrive at methodical clearness.

1. Law regulates only the external relations of men and communities. An external authority (i.e., outside I of the active ego) is always necessary for the creation of legal rules as well as for their execution; that is to say, for the establishment of law and the administration of justice. This authority (which is of the community) ${ }^{2}$ is one which does not recoil from the application of force. ${ }^{3}$ Concrete compulsion is not necessary as the object of a particular legal rule; but law nevertheless is excluded from those human activities where force is not possible. The design of the law is the establishment

of children, their nurture, and the diligent care of the household, are expressly declared to be the duties of the wife. (Manu IX. 27.) Indeed, the lawgiver raises himself to such a height as to lay down this rule for priests: "Let him wed a female free from bodily defects, who has an agreeable name, (the graceful) gait of a Hamsa or of an elephant, a moderate (quantity of) hair on the body and on the head, small teeth, and soft limbs."-Manu III, 10. With respect to this and similar well-intentioned counsels considered as rules, see J. Jolly, Recht und Sitte, p. 59. Concerning the confusion of moral and legal rules in the Moslem law, compare v. Tornauw, Die Disputation der Sklavin Husniyeh, in Zeitschr. f. vergleich. Rechtswissenschaft, Bd. IV, p. 472; also Das Erbrecht nach den Verordnungen des Islam, ibid., Bd. V, p. 116. See also Kohler, ibid., Bd. V, p. 384.

${ }^{1}$ Such a connection distinctly appears where law opposes the violation of morals, or raises morals to an authoritative standard. Compare B.G.B., secs. 138, 226, 817, 819, 826; Einf. G. z. B.G.B., art. 30. [Thus, "a juristic act which is contra bonos mores is void." The question of what is contra bonos mores is settled by recourse to prevailing public opinion (B.G.B. 138).]

2 This is not to be stated more forcibly than in the language of Windscheid: "Law is not what I conceive to be the law, but is that which the community of which I am a member recognizes as law to the extent that it has pronounced it."-Rectoral address, p. 7.

${ }^{3}$ Binding, Der Rechtszwang (lecture March 17, 1888, Vienna) (Appendix to "Normen," $2 \mathrm{~d}$ ed.). 
and maintenance of that external peace and security necessary in the striving for and attainment of the destiny of mankind. In this sense it means external order considered as a condition of life and as a consequence of law, and not a totality of legal standards (rules).

Commands and prohibitions which are established by law (or, more correctly stated, which are derived from the sources of law, and make standards) create, in favor of those whose interests are to be protected, titles (or, in the prevailing usage, rights and powers). When directed against others they are called claims (Ansprüche)." The conditions established by such titles and claims are protected by law by a variety of remedies such as suits (Klagen), pleas (Einreden), the right of self-help (Selbsthilfe), self-defense (Notwehr), rights of necessity (Notstand), protest (protestation, see infra sec. $15, I V, 2)$, etc. They culminate in the regulated use of force as in judicial execution, police force and military execution.

This realistic tendency of law does not derogate from the ideals of life and humanity. It is necessary in order that law may realize its purpose and to make room for the aspirations of civilization. Indirectly, law also has a great many ideal ends in the striving for which the dominant community establishes and maintains standards.

2. Morals ${ }^{2}$ (Sittlichkeit) regulate the internal rela-

1 Windscheid, Pand., sec. 43, and compare below, sec. 48, v (at the end).

2 Salkowski, Institut., secs. 2, 27, I.

According to a usage of speech not here of further interest. "morals" and "rights" are denoted together as "ethics"; ethics being understood as that of which morals and right are parts, - conformability to law in the free activity of men, or the necessary content of the standards for the development of mankind. (According to Kant, pure morals is the science of the necessary laws which condition free will, while ethics is that part of morality which is influenced by feeling, inclination and passion. Hegel limits the term "moral," 
tions $^{1}$ of men (i.e, their inclinations, feelings and ideas), operating on external relations only in so far as they are the expression of internal relations; or conversely, so far as they generate or influence such internal conditions. The object of morals is the perfection of the individual through himself, and thereby the perfection of mankind. The morally acting and morally thinking man recognizes that he is a member of mankind, and feels a sense of obligation to contribute through his own perfection his share in the attainment of the destiny of the individual as well as of humanity in general.

to the private duties of men as distinguished from their civil duties. "When St. Crispin steals leather to make shoes for the poor, that act is moral (moralisch) and wrong (unrechtlich), - a remark which explains Hegel's use of moralisch better than much commentary."-David G. Ritchie.

There is much confusion in the use of the terms "ethics" and "morals," but an adherence to the etymological distinction is not only serviceable on its own account but appears also to furnish a satisfactory distinction in fact. Ethics

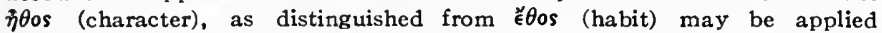
to the fundamental nature and investigation of those rules of conduct which implicate a free will; while morals (from Mos, manner, custom) may be applied to such rules of conduct in actual practice. Whether these investigations may be elevated to a scientific basis-which is denied by Sidgwick and asserted by Wund - is a matter of indifference to the distinction. This usage is also that which Austin proposed in an essay projected by him on "the principles and relations of law, morals and ethics; meaning by law, positive law; by morals, positive morals; and by ethics, the principles which are the test of both."-Preface to Austin, Jurisprudence, 4th ed. (1873), pp. 17, 18.]

1 [To say that morals regulate man's internal relations, while law regulates his external relations, would seem to employ a distinction which is inaccurate and misleading so far as it can be said to have any meaning at all. Morals is not limited to subjective states, nor is law confined to objective matters, and there is a great variety of matters which are at once the proper subjects both of law and morals. Criminal law in particular affords many concrete examples of each of these objections. The spheres of law and morals are intersecting circles, and the matters upon which they operate do not differ essentially either in degree or kind. There appears to be no reason other than that of practical expediency why either sphere should not be extended to include the other. The point of distinction between law and morals, however, remains unaffected-that the immediate force governing a moral act is an internal conviction, while in a legal act the moving factor is originally external, although when apprehended it likewise becomes, of course, an internal force.] 
The ethical destiny of humanity is the point of contact between morals and religion. Religion ${ }^{1}$ and philosophy ${ }^{2}$ coincide in the idea of development of the external life; in the capacity for and necessity of this development; accordingly, also, in the idea of improvement of the individual and the species; and in an approximation toward perfection. The fundamental principle of human reason (i.e., orderly generalization under higher and more general notions) has here also its significance. $^{3}$ Yet it involves in the domain of morals, in the first instance, a subordination and surrender of inclination; a motive for the generalization; and a harmonious relation between this surrender to the whole, and the maintenance of an internal perfection of the self as a part of the whole. - On this account, therefore, duties exist in morals,-moral obligations of the self against itself and against conscience,-but no titles, or claims against others.

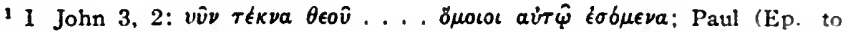

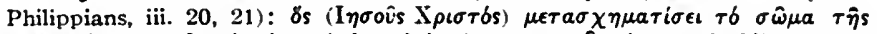

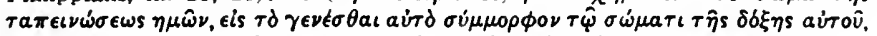

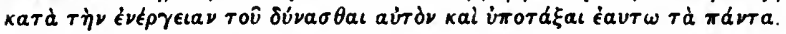

${ }^{2}$ Compare Immanuel Kant, collected works, yublished by G. Hartenstein, Bd. V (1867), Kritik der prakt. Vernunft, p. 86, and Kritik der Urteilskraft, sec. 83, p. 442 et seq., particularly p. 445; Fichte, Über die Bestimmung des Gelehrten und seine Erscheinungen im Gebiete der Freiheit, I; Felix Dahn, in Zeitschr. f. vergleich. Rechtsw., Bd. III, p. 5; W. Munzinger, "Erbrechtliche Studien" (lecture) (Basel, 1874), p. 23; Gareis, Privatrechtssphären, in Hartmann's Zeitschr. III, p. 140 et seq. and 153, and the same author, Irrlehren über den Kulturkampf (Deutsche Zeit-und Streitfragen, 1876), pp. 7. 8. Opinion differs as to whether the moral law admits of an absolute (or objective) content, and if it does, what this content is. Sigmund Exner, in his essay, Die Moral als Waffe im Kampf ums Dasein (Vienna, 1892), postulates an objective content of morals; namely, one furthering the maintenance of human society, without regard to the subjective will of the individual. The explanation of Exner regarding the feeling of pleasure with which every sound human society approves a moral act, and the bitter feeling of dis. pleasure which it shows toward an immoral act, is in agreement with the point above touched upon, concerning an inborn sense of order, and "the life for and through others."

${ }^{3}$ Compare F. Dahn, Die Vernunft im Recht. See sec. 2, notes pp. 5, 6.

- The principle of love, for this reason, governs in morals, - the absolute, independent concurrence of the interest of the one with that of others. 
The authority of morals is not external, but internal. It is a conviction supported by various influences which cultivate or affect conscience. This conviction (i.e., feeling, fides, or motive) is alone of significance in the moral valuation of an act.

"What is essential in the moral worth of actions is that the moral law should directly determine the will. If the determination of the will takes place in conformity indeed to the moral law, but only by means of a feeling no matter of what kind, which has to be presupposed in order that the law may be sufficient to determine the will, and therefore not for the sake of the law, then the action will possess legality but not morality." 1

Force, therefore, is not applicable in the moral valuation of acts. The motive is the important thing. Conviction itself must lead the way. The moral law mustdevelop its own recognition. The end of moral conduct is the establishment and maintenance of a harmony of inclination and purpose with the objects of human existence. ${ }^{2}$

\footnotetext{
${ }^{1}$ Kant, Kritik der prakt. Vermunft (Hartenstein ed.) I, 1, 3, p. 76 [this excerpt is taken from the excellent English transtation of Thomas Kingsmill Abbott (Longmans, Green, \& Co., 1909)]; also Einleitung der Metaphysik d. Sitten (1798) Bd. XXVI: "Act on a principle which may serve for a universal law." Compare Matt. vii., 12: "Therefore all things whatsoever ye would that men should do to you, do ye even so to them; for this is the law and the prophets." On the changing views of morals, as in the view of suicide in the Stoa and according to Kant, see Kant, Ethische Elementarlehre, Metaphys. d. Sitten (ed. of J. H. Kirchmann, Berlin, 1870), p. 262; and Knauer, Hauptprobleme der Philosophie (1892), p. 406. "Culpa est velle mori culpaque nolle mori."-Owenus. Views have entirely changed regarding prostitution. Compare on temple prostitution, Herodotus I, 199; Hammurabi (code), secs. 182 et seq.; prologue to Cornelius Nepos' Vitce. [Compare the kedeshah, which was according to Louis Wallis (essay on Biblical Sociology II, in The Am. J. of Soc., Vol. XIV, 3 (Nov., 1908), p. 322) a recognized institution of Israelitic society until a late period. According to Mr. Wallis, the same institution appears among all ancient Semitic people, citing Harper, The Code of Hammurabi (Chicago, 1904), secs. 110, 127, 178; W. R. Smith, Early Religion of the Semites (London, 1894). p. 455; Jastron, Religion of the Babylonians and Assyrians (Boston, 1898), p. 485; and also Hosea iv., 14].

${ }^{2}$ The difference between morals as an internal righteousness approaching perfection, and law as external legality, is clearly pointed out in the Sermon on the Mount. See Matt. v, 21 et seq.
} 
While there is accordingly an essential difference between law and morals, and certainly with reference to their objects, the one being external and the other internal; their means, force on one hand, and conscience on the other; their authority, in the one, the community, in the other, conviction; and in their ends, external peace and order on one side, and internal harmony on the other; yet in no sense is there any opposition between law and morals. Legal duties also may be moral duties.

Under sound legal conditions every infraction of law is also a breach of morals. Exceptions exist, but they presuppose unsound internal conditions. It is selfevident that it is not every breach of morals which is also an infraction of law. ${ }^{1}$

The connection between law and morals, amidst all their differences, is exceeded in intensity only by the connection between religion and morals. This connection is most unmistakably made prominent when external acts are designated by legal order as unlawful, whether as litigable or even as punishable, because they are contra bonos mores. ${ }^{2}$ It is possible to elevate a moral relation to the position of legal advantage.

3. Religion, in the first instance, is not of a prescribed or ethical, but a conceptional or metaphysical content. It signifies the notion of the absolute, and the direct relations of all finite realities to it. This idea is responsive to an instinctive feeling. It is the impulse toward direct knowledge of the sublime. A religious man arranges his conduct conformably to this impulse, and accordingly religion becomes for him a source of rules of action, consisting of commands and prohibi-

I F. Dahn, op. cit., sec. 18.

2 B.G.B., sec. 138 [a juristic act contra bonos mores is void] : B.G.B., sec. 826 lone causing willful damage to the property of another contra bonos mores is held in damagesl. See also note 1, p. 37, supra, and notes 5,6, p.47, infra. 
tions. These rules have it in common that their purpose is to apprehend and explain, and attain and build up, in harmonious accord, the immediate relation between inferior beings and the Absolute Entity, and the relation between individual ends and ideas and supreme reality. Human reason also functions here, but its generalizations are in accordance with inclination. Its generalizations are under authority, and do not operate, at least not solely, through force of mind, and never are realized without feeling and inclination. Finally, religion is generalization of the inclinations themselves under a supreme power, to know which is the highest end and endeavor of humanity. ${ }^{1}$

The authority from which these rules which presuppose or further generalization in accordance with inclination proceed and are sustained is internal, as in the case of morals. It is religious conscience or faith. This remains true also in those religious institutions where an external authority prevails, as where an ecclesia imperans commands, or an ecclesia docens instructs. Without an internal conviction, without the force of conscience derived from or influenced, (of course, by education, etc.,) the rules imposed by external authority would not bind the internal conviction of the individual.

Religious rules diverge from legal rules even when external acts, (as sacrifices,) are required. They are differentiated in their authority; in their purpose (direct apprehension of the absolute); and in their means and objects, both of which lie in the compass of the sensible world.

On account of these differences, an opposition is possible between matters of religion and legal rules, and unfortunately such opposition has also occurred. A

\footnotetext{
${ }^{1}$ Compare, F. Dahn, Wesen und Werden des Rechts, Z.f. vergleich. Rechtsw.. Bd. III, p. 5.
} 
dissimilar evolution of thought and feeling in the individuals of a community may become a disturbing factor in the event of decline of national religion, ${ }^{1}$ as well also as in case of reception of a foreign or anti-national religion. The community may command or prohibit an act by legal rule which conversely is prohibited or commanded by religion for individuals or a group of such within the community.

It is clear, however, that a co-ordination between law and religion, and between legal rules and religious rules, is not only thinkable, but that such connection has historically existed in all ages. When a community becomes influenced in its legislation by religious creed,that is, by the adherents of such, -in such case there is not only no discordance between the law of the state in its legal rules generally and the institution of religion, but religious rules are advanced to the standard of legal rules. Accordingly the fulfillment of religious duties, or the acceptance of a religious viewpoint under legal force, is established. ${ }^{2}$ Law, therefore, easily oversteps

'The anthropomorphic and polytheistic form of the notion of the deity. by which religion is thrown into opposition with morals on one hand and philosophy on the other, may be regarded as the chief cause of the disagreement noted. See F. Dahn, Das Tragische in der german. Mythologie, Bassteine, Bd. I (1879), p. 102.

${ }^{2}$ Fxamples: An exclusive state church (ecclesia dominans) and prosecution of every confessio reprobata; the death of Socrates; the early persecution of Christians; and the execution of heretics in the Middle Ages; state enforcement of religious acts, as, for cxample. in the following rules of the Paderborn Synod, year 785:-

“4. Si quis sanctum quadragesimale ieiunium pro despectu christianitatis contempserit et carnem comederit, morte moriatur; sed tamen consideretur a sacerdote, ne forte causa necessitatis hoc cuilibet proveniat st carnem comedat.

"8. Si quis deinceps in gente Saxonum inter eos latens non baptizatus se absconidere voluerit et ad baptismum venire contempserit paganusque permanere voluerit, morte moriatur.

"19. Similiter placuit his decretis inserere, quod omnes injantes injra annum baptizarentur; et hoc statuimus, ut si quis infantem intra circulum anni ad baptismum offerre contempserit sine consilio ael licentia sacerdotis, si de nobili genere fuerit. centum viginti solidos fisco componant, si ingenuus sexaginta, si litus triginto. 
the bounds presented by the notion of a regulation of the external relations of men to each other. A hypocritically assumed or sham sanctity appearing in the guise of religious conviction expressed in external conduct (as, for example, murder from religious conviction, the practices of the Adamites, religiously masked impostures, etc.) furnishes no ground for excluding the interference of the state through its legal order. The religious impulse exhibits other external relations when it. appears in the communistic sense, as in the case of religious conmunities or associations. These associations, so far as they are external relations of persons, are an object of legal adjustment. Accordingly they are subject in their external relations to the authority of that community from which legal rules proceed and by which they are maintained.' On the other hand, dominant communities, historically considered, frequently employ religious ideas in order more securely to accomplish their own objects. Political institutions are surrounded by or based on religious notions. Legal systems are fortified by the oath (as, for example, the oath of allegiance, office and of witnesses), or may be supplemented thereby, as in a system of evidence employing the ordeal (Gottesurteil).

The internal co-ordination of law and religion, and of morals with both, is of far greater significance in the history of civilization than the external connections indicated. It is apparent that the state of culture of the people generally is of influence in all manifestations

"21. Si quis ad fontes aut arbores vel lucos votum fecerit aut aliquid more gentilium obtulerit et ad honorem daemonum comederit, si nobilis fuerit solidos sexaginta, si ingenuus triginta, si litus quindecim. Si vero non habuerint unde praesentialiter persolvant, ad ecclesiae servitium donentur usque dum ipsi solidi solvantur."-Monum. Ger. Historica, LL., sec. II; Capitularia regum Francorum, Tom. I, cap. 26, pp. 68, 69.

${ }^{1}$ Compare infra, "Religious Associations as Juristic Persons, sec. 15. See also, sec. 57 . 
of the spirit of a community and its members. A people of low or barbarous religious notions will have and probably will employ a barbarous law; and the legal system of a people of profound and noble religious convictions will not be destitute of the splendor of human dignity.

4. Social convention or social deportment (Anstand) has a feature in common with law, in that it indicates rules for the external conduct of persons among themselves. Social deportment and its commands arise from custom, or may proceed from views in certain ranks and positions in society, or in particular stages of civilization, conformable only to the moment and obtaining only in externals. Social convention depends, therefore, far more than law on the feeling of station and the conception of culture or mode, and relates only to the forms and incidental phases of human acts; as, for example, manner of speech or of carriage, mode in dress, fashion in amusement, and style in art. It is concerned with the externals of conduct, which is refined or made more convenient or agreeable through rules of social deportment.

The connection between social deportment on one hand and law and morals on the other is unmistakable. But a conflict may exist between that which is required or forbidden according to the notions of deportment of a particular class in society (and perhaps also the notions of the whole of society), and that which is opposed or demanded by positive law. ${ }^{1}$ The authority of deportment resides in part in the force of tradition and custom, and in part on what is a pure opposite to this, the views of the day, or the time-spirit ${ }^{2}$ of the moderns. The object of deportment is the refinement and making

' Compare. for example, R.Str.G.B., sec. 201 (Gareis, R.-gesetze, No. 143-146).

${ }^{2}$ Zeitgeist. 
agreeable of external conduct, in which conviction and feeling are equivalent elements. The means by which social convention exerts its force or sanction lies in the attitude of society or the classes within society, ${ }^{1}$ which involves compulsion by social exclusion and the erection of standards of conduct. The notion of what is proper, and what is not, changes with or without perceptible connection with the progress of society. ${ }^{2}$ This is also true of legal rules. The relation of social convention to law, apart from the consideration that certain duties of social deportment may be designated as natural obligations (naturales obligationes), ${ }^{3}$ is more effective in this,- that violations of deportment are not infrequently considered as legal wrongs and invested with legal consequences. ${ }^{4}$ These legal consequences may provide for the nullification of juristic acts, removal from service or office, ${ }^{5}$ statutory deprivation of civil rights, ${ }^{6}$ disciplinary correction, ${ }^{7}$ and criminal punishment. ${ }^{8}$. The de-

\section{${ }^{1}$ Noblesse oblige.}

${ }^{2}$ Compare the change from the courtesy of the eighteenth century with the tone of the Directory and the Empire. Cf. also the manner of speech in the court according to Shakespeare.

${ }^{3}$ Not in the technical sense of the Roman law.

${ }^{4}$ A noteworthy illustration: A Brâhmana who does not invite his next neighbor and his neighbor next but one, (though) both (be) worthy (of the honor), to a festival at which twenty Brâhmanas are entertained, is liable to a fine of one mâsha.-Manu VIII, 392.

A Srotriya who does not entertain a virtuous Srotriya at auspicious festive rites shall be made to pay him twice (the value of) the meal and a mâsha of gold (as a fine to the king).-Manu VIII, 393.

5 The expression "contra bonos mores" is also employed in connection with violations of social deportment.

${ }^{6}$ Infamy, turpitude, levis macula. Special grounds of disinheritance may be also noted here. Compare B.G.B., sec. 2333,5 [a testator may deprive a descendant of his compulsory portion if the descendant leads a dishonorable or vicious life against the will of the testator] with sec. 1568 [either spouse may apply for divorce if the other has disturbed the marital relation by grave violation of conjugal duty or by dishonest or immoral conduct to an extent incompatible with the marriage].

${ }^{7}$ Cf. Reichsbeamtengesetz (March 31, 1873) secs. 10, 72.

${ }^{8}$ Compare: Affronts (Beleniigung), R.Str.G.B., sec. 185; gross mischiefs (Grober Unfug), sec. 360 , No. 11 ; sec. 361 , No. 6; unchaste acts, secs. 183 . 184. 
meanor required by the demands of social convention becomes by means of such legal consequences the object of a legally protected interest, whether of the individual or the community.

5. Equity, or justice (Billigkeit), is the conception of individual conformability of an act or a condition arising from the feeling of law, of morals and of class, in connection with the mental attitude of the person. In the light of all the relations which his individuality apprehends in a concrete case, one says: "It is right to act thus or so"; and by this is meant that the act harmoniously corresponds with the concrete relations of the case and the demands of "even-handed justice."

The claims of justice are not law in themselves, even though the legal sentiment of a whole people would annex them and seek to discover in them the ideal of the development of law. "Until this ideal is realized, and until justice is recognized as a source of law, justice is not law. The judge would seriously err should he be partial to justice as against the positive law of his people, or desire to substitute his notions of justice in the place of law."1 Justice or equity of itself lacks external authority. Its source is exclusively pure subjective discretion or judgment. Indeed, it is hardly judgment regarded as a process of reason, but rather a sentiment, or expression of feeling -an ideality which the law may approach but which has no direct, binding force.

\footnotetext{
1 Windscheid, Pand., sec. 28. Equitas in the sense of the Romans is to be distinguished from equity [Billigkeit] in the sense above. Jus aquum was positive law and stood in opposition to $j u s$ strictum. Cf. Windscheid, loc. cit.
} 


\section{SECTION 7}

FOUNDATIONS ${ }^{1}$ OF THE LEGAL STRUCTURE (SYSTEM)

The origin and maintenance of law, and the logical and practical existence of that peaceable order which makes the law, would not be possible without (1) freedom of will; (2) a governing social organism; (3) the necessity of a definite civilization.

1. Freedom of Will.

The proposition has been stated that man not only experiences a variety of necessities, but also feels within himself the egoistic impulse to satisfy them. This impulse is directed to bringing about a condition in which the necessities which are experienced are satisfied. Man resorts to acts pursuant to this impulse. If these acts were entirely dependent on the mechanical forces of nature, as when a stone falls from the opened hand, there would then be no room for law, or for morals either, as commands and prohibitions have no influence on falling bodies. When we speak of the necessity and possibility of legal order, it is necessary, therefore, to predicate beings upon which command and prohibition can make an impression - that is, entities which have a capacity of choosing.

The method by which command and prohibition operate on human action is a matter of controversy. ${ }^{2}$ It is sufficient here to say that the egoistic impulse from

1 The term "foundation," or "basis" (Grundlage), is treated in another sense in the very interesting essay of Bernhöft in $Z$. f. vergleich. Rechtswissenschaft, Bd. II, p. 253. The point of Bernhöft's discussion is considered in part in sec. 8,2 , and in part in sec. 7,3 , infra, principally with reference to the influence of civilization on the legal system.

${ }^{2}$ Compare on these controverted questions, chiefly in the domain of criminal law, v. Liszt, Lehrbuch, secs. 28, I; 29, III; 36, III, and the highly important literature there noted. 
which we started is based on the faculty of perception, by which not only a state of necessity or want, but also a state in which the want is satisfied, is represented to the individual. These ideas become the motives of acts, through which acts the individual displaces a state in which a want is felt by a condition in which satisfaction of the want is perceived. The act leading to the condition desired follows from the impulse generated by the double representation of a condition of want and one of satisfaction. The point from which legal order proceeds, lies in the situation precedent to the act. When an act is incompatible in itself or in its consequences, in the view of the overruling social organism. with an harmonious social life; when it is inconsistent with the ends of society and its cultural development; or even is contrary to certain purposes of the dominant social organism; then it is forbidden, or its opposite is commanded.

Command and prohibition operate on the same plane as the impulse of want,- that is, on the sense of perception. They exhibit then to the individual the legal and actual consequences of the observance or non-observance of legal commands or prohibitions. They thereby create motives which are usually sufficient to restrain incompatible acts, and to bring about the doing of that which the social life of man or the view of the community requires. The bringing to bear of motive against motive is the political side of legal order. It has for its design the institution and maintenance of peace and the advancement of civilization and humanity.

It is a matter not to be disregarded that the impulse of want and legal rules both operate through the medium of the faculty of perception. Legal commands and prohibitions are inoperative against beings without the faculty of perception, or with undeveloped faculties of perception. Accordingly, acts of beings with no co- 
ordination between the perceptive faculties and the excitation of the motor nerves necessary for the completion of a [juristic] act, or lacking a psychological freedom of choice, are not acts in the law. ${ }^{1}$ Incapacity for responsibility and the resulting invalidity of juristic acts of the insane illustrate this point.

The average interests of the average individual must be considered in the creation of new motives to counteract impulses of necessity. This is essentially matter for legislation. The prevalence of certain offenses will suggest to the legislator the intensification of counteracting motives. Failure to overcome the impelling motive of the offender does not furnish argument against the correctness of this view, but indicates either abnormality of the internal or external conditions of the criminal, or general unfitness of the legal command or prohibition. It may be too weak to generate legal motives or threats of punishment against the motives of the offender, or it may be generally inadequate.

\section{A Governing Social Organism.}

Legal order is only possible and only necessary when men live together in a state of society and form a community. There is no legal order in isolation, or for persons living apart. Two kinds of legal order arise, however, when persons live together in numbers: first, that arising out of the existence of interests of the persons living together and forming the community; ${ }^{2}$ and, second, that arising from interests which are different from, and possibly even opposed to, interests of the individuals forming the community. In the second class of interests, however, there is a leading interest, namely, an interest in an authoritative organization in such community. The premise of every legal system is

${ }^{1}$ Cf. p. 102, note 2, and p. 103, note 1, infra. [The German expression for acts wanting in legal validity is sollenden Handlungen.]

${ }^{2}$ These interests spring from the impulse of sociality, - the social instinct. 
the existence of a community within which common or social wants are felt and in which an external authority is displayed. This community is called a governing or dominant community or organism, in so far as it is able by its own choice to make its own interests legal interests, and to protect and guarantee them as legal interests by its own choice of means.

Such a community exists in its simplest, most natural and most primitive form in the family, or association of kindred. The family is historically the starting point of all those social organizations which have been and are of most effective influence on the legal system. ${ }^{1}$ The social unity of humanity in conformity with nature, both physiologically and ethically, depends on and requires the family in serving the moral destiny of mankind. The domination and subordination which in the state are indicated by the distinction between government and the governed are first seen in the family. In it the authority which in the governing community belongs to legislation and administration is earliest found. Legislative and executive powers, the latter including administrative and judicial action, have their starting point in the authority of the family head, or patriarch. As long as no other community is dominant over the family, it is itself to be regarded as a state,-a patriarchal state, or (what is somewhat different) as a heroarchy.

The oldest traditions of all known peoples, in which history and fable are interwoven, argue for the necessity of acceptance of such an origin of the state. The traditions of the Hebrews suggest repeatedly ${ }^{2}$ the priority of

1 "The primitive development of mankind was collective. The individual advanced at first by slow and gradual steps. Humanity primitively had the root of its being in the family."-J. Kohler, in K. . v. Holtz. I, p. 27.

2 Adam's descendants ( $c f$. Moses (Genesis) I, 5, 1), Noah's descendants (loc. cil., cap. 10, 8). Abraham's descendants, and the patriarchal pastoral state (Moses I, 13). But David founded a heroarchy (Kings I (Sam. I). 25; Kings II (Sam. II)). Cf. Bernhard Stade, p. 57, note 1, infra. 
the family to the state. With more or less legend about it, the existence is well known in the traditions of the Greeks of tribal communities of all the descendents of the Atridæ, with features characteristic of associations of kindred,-kin-revenge (Blutrache), hospitality (Gastfreundsclaft), etc. The fact of the extension of family aggregates into local communities, and the cohesion of these local communities in kingly power, are also well recognized. ${ }^{1}$ Even the legislation of Justinian among the Romans in the after-operation of remnants of previous legal development expresses the extraordinary importance in public and private law of patriarchal power and the family tie. ${ }^{2}$ The family-state (Familienstaat) organization of the dominant community has persisted up to this age among the Slavs, - at least among the south Slavs, ${ }^{3}$ - to an extent even where the limits have been exceeded $^{4}$ up to which the family association has a political mission in the organization of the state.

Among the Germans, also, the notion of state leads back in legend and in history to the significance of the family, and this was true everywhere that German states were founded,-in Scandinavia, in Germany, in France

1 The Odyssey exhibits the purely patriarchal state among the Cyclopes:

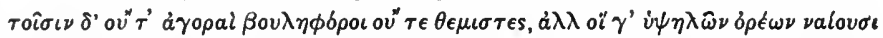

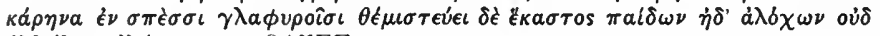
$\dot{a} \lambda \lambda \hat{\eta} \lambda \omega \nu$ a' $\lambda \epsilon \gamma o v \sigma \iota \nu .-O \Delta \Upsilon \Sigma \Sigma$. IX 112-115.

The Greek (of the time of Pericles), however, can not yet recognize a state or legal order in such isolated domestic arrangements, and therefore the

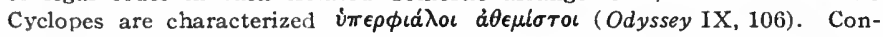
cerning kin-revenge (Blutrache) as a duty and as an expression of the kindred tie, see Odyssey XV, V, 273-276; also, I, 40, 41. Compare also Bernhöft in $Z$. f. vergleich. Rechtswiss., Bd. I, p. 13.

2 This suggests the legal conception of the family among the Romans, manus, and patria potestas with its jus vite ac necis, and the significance of the gens and gentiles.

${ }^{3}$ Cf. Paul Turner, Slavisches Familienrecht (Strasburg and London, 1874), pp. 10,14,37, where the import of the zadruga (the household, the family. with the gospodar, or stareshina, at the head), the shupania, and the great Shupanie or Grossvoivodschaft, is particularly made prominent.

4 To this may be attributed the decay of ancient Poland and ancient Servia. 
to the left of the Rhine and the Meuse, in the Lombard domains, etc. The branching out of the most ancient race stems is based, ${ }^{1}$ according to tradition, on descent, patriarchal-heroic unity, and family division. But the demonstrable importance of kinship among the Germans in historical times, according to etymology and legal history is, however, of greater interest. ${ }^{2}$

Legal order may be considered as based on a relationship of the kindred, since hostility among them would lead unmistakably to the downfall of the world. ${ }^{3}$ Within the kin (Sippe) the feud is excluded, and legal order is first and alone admitted." Legal peace, it is apparent, extends beyond the limits of the kindred association. In Germany this extension was first accomplished by means of purchase-settlement of the feud (Abkauf der Fehde), in the so-called composition system. In historical times - as early as the time of Tacitus - there was permanent residence of many German stocks, so that

1 Tacitus, Germ. 2: Celebrant carminibus antiquis, quod unum apud illos memorice et annalium genus est. Tuisconem deum terra editum, et filium Mannum originem gentis conditoresque; Manno tres filios adsignant, et puorum nominibus proximi Oceano Ingavones, medii Herminones, ceteri Istavones vocantur.

2 The Germanic notion of state begins with the smallest conceivable association. It limits itself to the primary social aggregate out of which the state developed, - the family. Sibja means family, stock, gens, peace, legal protection and pax. Compare sifjahr (old Norse, fem. pl.), the kinsmen; sibja (Gothic), the interrelated tribes, relationship, friendship, congeniality: society; sibbia (old Saxon) or Sippe (middle high-German), peace, unity, relationship; Sabha (Sanskrit), communitas. See August Fick, Vergleichendes Wörterbuch der Indogermanischen Sprachen, 4 th ed., revised by Adalbert Bezzenberger, August Fick and Whitley Stokes, I, p. 326 (Gottingen, 1891). Thus sabhya means belonging to a community, "therefore conforming to custom"; see F. Dahn, Im newen Reich (1875), No. 11, p. 413, and Bausteine, Bd. I, p. 417. An analogy is presented to the last notion in the meaning of civis, civilis, civiliter and "civilized."

3 "Brothers would contend and murder. Sisters would plot the ruin of the kin." -Voluspa in the Edda, Woleogen, p. 148. See also F. Dahn, Bausteine I, p. 417, and Im neuen Reich (1875), p. 414. Cf. Heliand, 132: Endi heri ledid kunni obar odhar (ot exercitum duxit una gens contra alteram).

- F. Dahn. Fehdegang und Rechtsgang der Germanen, Bansteine, Bd. II, p. 79 . 
the state was no longer an association of kindred, but had extended over local communities (Gaue), and even into tribes (Volkerschaften). The kin element and the importance of the authority of the head of the family are, however, still to be observed in the territorial settlement of the kindred, and principally in the names of places founded by and named after the chiefs of kindred. ${ }^{1}$

The fact of settlement of other kindred in the same place-as, for example, in the same valley-and the formation of the mark association (Marca, Markgenossenschaft), which is the first community-state (Gemeindestaat), exhibited a harmony of interests of the neighbors. These facts indicated a union of common stocks, or other associations of interest of the kindred, who took possession of the undivided common (Allmende), wood, or pasture surrounding individual property (Einzelgüter, ville, mansus, mansiones, hobe, Höfe), and made their boundaries (Marken) the object of common administration and defense. ${ }^{2}$.

\footnotetext{
1 This includes chiefly the many local names which end with "ing" or "ingen," and which commence with the name of a person, that of the head of the family settling the locality; the local names ending with "rod" ("reut," "richt," and "rad"), or with "brand" or "schwend," to designate the first settler or conqueror of the forest; and those ending with "heim," "lar," "hausen" and others, to indicate the builder. Cf. W. Arnold, Ansiedelungen und Wanderungen deutscher Stämme, Zumeist nach hessischen Ortsnamen (1875, 1876); A. Meitzen, Der älteste Anbau der Deutschen, Jahrb. f. Nat. u. Stat., No. 1, Bd. II (Jena, 1881) and literature cited, particularly v. InamaSternegg, Deutsche Wirtschaftsgeschichte.

${ }^{2}$ With reference to these connections between colonization and state evolution among the Germans there exists an economic, juristic and historical literature of great importance. Of these works may be noted: L. v. Maurer, Geschichte der Markenverfassung in Deutschland (1856) and Einleitung zur Geschichte der Mark-, Hof-, Dorf- und Stadtverfassung (1854); Fr. Thudichum, Die Gau- und Markvesfassung in Deutschland (1860); Geo. Waitz, $\ddot{U}$ ber die altgermanische, Hufe (1854) and Das alte Recht der salischen Franken (1843), p. 125, also Deutsche Verfassungsgeschichte, Bd. I, II $(1865,1870$, 1874, 1880): W. Arnold, op. cit.; Felix Dahn, in Könige der Germanen, Bd. I (1861), also Bausteine, first series (1879), pp. 282, 396, 422, 528; second series (1880), pp. 150, 372; sixth series (1882), p. 157; also Dahn, Deutsche Geschichte, Bd. I, p. 183 (1883), and Urgeschichte der german. u.
} 
Necessity impressed upon the community-state a constitutional unity of contiguous communities. Accordingly there arose the Gau (pagis, or district ${ }^{1}$ ), as a Gaustate (district-state). This form of state had a special state organization of its own-as, for example, Gau (district) courts,--in so far as the district claimed and established interests peculiar to itself opposed to the mark associations (Marce), to single kindreds and individual holders of farmsteads (Hofbesitzer). The original district-state already presented differences in form and organization, at any rate in its subdivisions; thus, communities (Gemeinden), kins (Sippen), farmsteads (Höfe), sometimes ${ }^{2}$ hundreds (centenen, or centen), and peculiarly organized villages. The growth of civilization, and (perhaps of greater importance) the exigencies of war, brought about a greater interdependence and unity. A number of districts, perhaps all of related stocks, combined in a political and constitutional ${ }^{3}$

roman. Völker, in W. Oncken's Geschichte (see note 3, p. 57, infra); Heinrich von Sybel, Entstehung des deutschen Königtums; Dahn, Zur älteren deutschen Geschichte in the Deutsche Revue, Bd. VII (1882); Laveleye, De la propriété et de ses formes primitives, 2d ed., 1877 (a German translation by Büchner, 1879); Kohler, in the Krit. Vierteljahrsschrift, Bd. XIII, p. 1; Heusler, Institutionen des deutschen Privatrechts, Bd. I, p. 262; N. Roscher, Ansichten der Volkswirtschaft (1861); Geo. Hanssen, Agrarhistorische Abhandlungen (1880); A. Meitzen, Der älteste Anbau der Deutschen (Jahrb. f. Nat.- Ök.); v. Inama-Sterncgg, Deutsche Wirtschaftgeschichte, Bd. I, (1879); K. Lamprecht. Wirtschaftsleben I and Deutsche Geschichte II (1892). [Sec also Hallam's Middle Ages; Stubbs, The Constitutional History of England; Seebohm, The English Village Community; Seebohn, Tribal Custom in Anglo-Saxon Law (Longmans, Green, \& Co., 1902); Nasse, The Agricultural Community of the Middle Ages (tr. from Ger. by Ouvry. London, 1871); Nasse, Village Communities (Contemporary Rev., May, 1871); Gummere, Germanic Origins (Chas. Scribner's Sons, 1892).l

1 Compagenses, a union of Gaue (districts, Gaugenossen); see Schröder, Deutsche Rechtsgeschichte, p. 121. Concerning the constitution of the Gau, see Riezler, Ceschichte Bayerns I, pp. 126, 841: Brunner, Deutsche Rechtsgeschichte II, 146.

2 Among the Goths and Chatti; cf. Gareis in 3 Jahresbericht des Obcrhess. V. f. Lokalgeschichte (Giessen, 1883), pp. 63, 64, and literature there noted.

3 This expression may be used to indicate the distinction between this kind of confederacy and those simple offensive and defensive alliances which precede and lead up to confederation. 
unity. Thus there arose among the Germans as early as in the second century A. D. a typical tribal state (Volkerschaftsstaat, civitas).

Again, if a number of tribal states, forced ${ }^{1}$ by the necessities of war or other causes, joined together, then there arose a widely comprehensive state, which has in German legal history received the name people-state (Volksstaat). At the head of this state stood a popularly elective king (Volkskönig) or duke (therefore, a popular kingdom or dukedom). ${ }^{2}$ This movement culminated in the highest stage of state unity, - a national kingdom (therefore, royal or imperial power, such as was that of Charlemagne). From this point German history presents a series of intermediate and retrograde governmental forms,- - the empire of the Middle Ages, the feudal state (Lehenstaat) and the development of territorial sovereignty of the separate members of the empire,until a concentric movement again (1870-71) produced the German Empire. We may still recognize over the greater part of modern Germany, under different names and with new boundaries, the people-states (regna, ducatus) in the confederated members of the empire, the tribal states (civitates) in the provinces of the members of the empire, and the district-states in the subdivisions of the provinces. ${ }^{3}$

It is a matter of significance in the development of law that each of these social communities, - the household, the community, the district, the tribal unity, the people and the empire,- - though differing widely in a

${ }^{1}$ Cf. Bernhard Stade, Geschichte des Volkes Israel, in W. Oncken's Allg. Gesch. in Einzeldarstellungen, pp. 173-176, in which the grounds are stated which occasion the origin of kingly power; in particular, the pre-eminent necessity of law and security for the tiller of the soil, as distinguished from the wandering and warlike nomad.

${ }^{2}$ Cf. W. Sickel, Hist. Z., Bd. XVII, p. 407.

3 With reference to these evolutionary stages see Felix Dahn, Urgeschichte der german. u. roman. Völker, in Wilh. Oncken's Allgemeine Geschichte in Einzeldarstellungen I, abt. 23, particularly p. 77. 
territorial sense and in range of function, has a mission in the building-up of law. Each of these forms does not fulfill this vocation in all directions. If there is assigned to the state (understood as a legally independent social organism, or as the temporarily supreme social community) the mission of constructing a legal system, yet it is not to be overlooked, on one hand. that this is not, by any means, the only function of the state; nor, on the other, that this evolved form of state arising out of precedent social communities or state-forms may relinquish to these antecedent communities the development of their autonomous law. By this means, a particular method of creating law-autonomy in the modern sense, and custom (Observanz) in the technical sensehas been generated. The law-making function has remained partitioned notwithstanding political unity. Examples of this partition of law-making are the legislative powers of autonomous provinces and communities; and it exists even in autonomous families. ${ }^{1}$

As long as the state and the family are coincident, and therefore the state exists in its smallest conceivable extent, so long does the state exert all economic, juridical, and law-fostering activities. ${ }^{2}$ Differentiation of function is accordingly first thinkable and actually arises when a higher social organization overshadows the kindred. In the first instance, this is perhaps the community; as, for example, among the Germans, the local association called the Markgenossenschafl. The latter community, therefore, has to represent its own peculiar interests by the establishment and administration of standards in the same manner as the highest form of social community. The household, however. has its own peculiar interests to pursue and provide for,

\footnotetext{
1 See sec. 12, below.

3 Therefore, the patriarchal state is a socialistic state. See below, secs. 40. 41 .
} 
within its limits, and as to which the community lays no claim. Individual interests, family interests and community (state) interests are, therefore, already differentiated.

The inter-opposition of these social forms naturally increases, the more as the dominant social organism, the state, develops in accordance with territorial extent and range of function. In the Germanic popular kingdom (Volkskonigtum), the partition of this function was such that the development and furtherance of law pertaining to the state, as well as to the districts, the community and the family, were respectively relinquished to them. The kingdom assumed as its province legislative and administrative control of penal judicature (Blutbann), the king's forests (Bannforsten) and all military affairs (Heerwesen). It reserved at least a superintendence by kingly officials over local courts (Gaugerichte). There remained, as against this power, to the lower organizations, - the districts, district courts, communities, mark assemblies (Markerdinge), and the family,-nearly all economic (Wirtschaftspolitik) and police administration as well as inferior judicial matters (Gerichtswesen) and the development and administration of substantive civil law.

Notwithstanding the official preponderance of such inferior associations as districts and communities within the Frankish kingdom, it is not to be understood that these lower organizations were the only binding tie between the subject and the state, as must be assumed in the case of strictly feudal communities where feudal dependants (Untertanen) were subject only to their immediate feudal lord and were subject to feudal superiors only through him. The Frankish state was rather based upon a general organization of feudal dependants, by force of which there existed a direct relation of protection and fidelity between the individual 
subject, whether as a member of a community, a district or a dukedom, and the sovereign or king. There existed, accordingly, a direct relation ${ }^{1}$ by virtue of which feudal dependants were bound to military service ${ }^{2}$ (Heerpflicht), and duties with respect to attendance at judicial assemblies $^{3}$ (Dingpflicht) and the maintenance of the envoys ${ }^{4}$ of the king and nobles. In return, the king guaranteed ${ }^{5}$ protection against war from without, and the protection of law and police within.

In a union of people-states, kingdoms or ducal states in a higher form of state organization, as in an empire (natio, imperium), the identity of the lower forms of organization may be destroyed, as in the unitary state of France; or this unification may result in a loose and rarely existent form of feudal association; or in one of the forms of composite states. The subjection of individuals to the supreme organization even in composite states may be direct, as is characteristic ${ }^{\circ}$ of the Bundesstaat, or it may be mediate only. ${ }^{7}$ It is evident that the distribution of powers between the supreme organization and inferior departments is of extreme variation, as qualified by historical facts. ${ }^{8}$

- However diverse may be the competence and functions of the social community, the greatest of which appear in the composite state and the public organizations within it, yet one of the missions which the state-

'See Ehrenberg, Kommendation und Huldigung, nach frônkischem Rechte (1877), pp. 1, 115.

2 "Cum comite swo in exercitum pergant." There belongs here aiso the duty of guarding territorial boundaries. See Ehrenberg, loc. cit., pp. 3, 108.

3 "Ad mallum comutis venire," and including attendance at specially commanded judicial assemblies (gebotenes Ding), "si necessitas fuerit vel denunciatio regis urget," as well as regular judicial assemblies not especially convened (ungebotenes Ding). See Brunner, supra, p. 197; Ehrenberg, op. cit., p. 2.

1 See Ehrenberg, op. cit., p. 3.

5 See Ehrenberg, p. 1.

- Cf. Gareis, allg. Staatsrecht in Marquardsen's Hdbch. I, p. 106.

7 As in a Staatenbund; see Gareis, loc. cit., p. 114.

See below, secs. 11, 42, 43. Cf. Art. 4, Constitution of the German Empire of April 16, 1871. 
that is, the supreme or dominant organization, for the time being-provides for, and must provide for, is the establishment and maintenance of law. Conversely, the state, according to modern legal view, is one of the essential conditions precedent to the existence and administration of peaceable order in the external relations of mankind. (See secs. 8, 11.)

\section{The Necessity of a Definite Civilization.}

This premise of legal order is true in a twofold sense. In the first place, it is a logical necessity. Peaceable regulation of the external relations of persons among themselves is possible only when such external relations exist, and when, in consequence of these relations, regulation is perceived as a necessity by virtue of the sense of law. The forces which we called the roots of the law become operative as the foundations of this necessity. It follows, however, that the kind of wants, their intensity, the kind of assertion of the impulses which correspond to these wants, and the kind of satisfaction of these wants, depend on the condition of social development of a law-creating or law-fostering community of civilized persons. ${ }^{1}$ The kind of commands and prohibitions, as also the intensity of the threat of legal punishment over the disobedient, also depend on this. An Alpine people following chiefly pastoral pursuits require different laws from a commercial people with complicated monetary and credit activities. Half-civilized nomads require for peaceable order among themselves other standards than a highly civilized people.

1 Therefore in a much wider sense law is, as Hugo Grotius (de jure belli ac

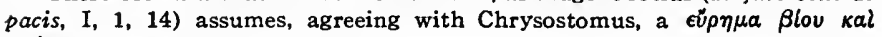

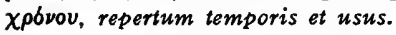




\section{SECTION 8}

\section{THE STATE AND LEGAL ORDER}

Every legal regulation owes its practical efficacy to the governing social organization. All law and all administration of justice are to be regarded as institutions of the state. ${ }^{1}$ It can not be said, however, that the state is the only source of $1 \mathrm{aw},{ }^{2}$ since the state may relinquish to other agencies the making of rules for the external relations of persons in society. Thus, matters of fact or conditions may spontaneously generate rules as in custom and through jural necessity. ${ }^{3}$ Law may

1 This notion is the subject of much controversy. It is opposed by the Naturrecht (law-of-nature) conception which affirms that the authority of law lies in its conformity to human reason. It is also opposed by a portion of the historical and law-of-nature school in so far as a popular consciousness of law is regarded as the source of legal standards, and further by a moralistic notion which discovers the binding force of legal rules in their ethical force.

2 This proposition may be so understood that its negation will contradict the previous statements. This difficulty will not arise if the word "source" is correctly apprehended. A source of law means that agency which provides its material, just as the water of a brooklet comes from the spring. The stream, however, does not owe its force to the spring, but to other agencies, as to the attraction of the earth, and the condition of the bed of the stream.

The analogy lies in this: The state alone, so far as it legislates, furnishes the material of legal standards, the expression of commands and prohibitions. the precepts. It creates the material, the rules, by its declaration of laws, and gives them the force of its authority. Where, on the contrary, other sources of law-autonomy, custom and legal necessity (Rechtsnot) -operate, and provide the material of legal standards, then it is the function of the state to establish these rules by its authoritative power, in so far as this appears to the state necessary or desirable for the protection of interests.

${ }^{3}$ See customary law and law arising from necessity (notwendiges Recht). secs. 9, 10,12 .

The state bears a fivefold relation to legal order. This may be expressed as follows:-

1. Respublica jus sancit: the state gives law its authority. The governing social organism designates as law that only which it recognizes as law (see p. 37, note 2, referring to Windscheid's Rectoral address, p. 7). This is true not only of legislation, but also of custom and autonomous law. 2. Respub. lica $j$ us condit (constituit): the sta te makes legal rules by laws. 3. Respublica jure utitur. It employs laws, or legal commands and prohibitions, to attain 
be formulated by associations inferior to the state. ${ }^{1}$ There may also be law expressed by state communities within the state, afterwards becoming defunct, or afterwards growing up; by powerful associations within the domain of the state; and by foreign communities which the state may annex. ${ }^{2}$ Such rules for the external relations of men in society, and not established by the state, - may have a binding force for those persons among whom the rules have arisen without or before any notice taken by the state of these rules. Under the conditions in which they originate, these rules may have a force arising from conscience, moral or religious views, ${ }^{3}$ the influence of the word of honor, or of class feeling, ${ }^{4}$ or from pure considerations of utility. This force may be, as in the first cases noted, highly ideal; but these rules are not of themselves legal standards. There is wanting in them the authority of the dominant social organization. That only is law which the state recognizes as law. This holds so universally that we do not by any means always recognize as law what another state may hold as law, even with reference to the subjects of that state. ${ }^{5}$

The recognition on the part of the state whereby a rule becomes a rule of law may be express or implied, or direct or indirect. Thus the state allows a legal validity under certain conditions to ecclesiastical and

its ends; for example, when it ordains general military duties, or duties with respect to education, or when it threatens punishment against everything opposed to its objects. 4. Respublica jus dicit, in the administration of justice (secs. 47, 50). 5. Fiscus legibus subditus est (sec. 15).

${ }^{1} C f$. autonomy, below, sec. 12.

${ }^{2} C f$. international law (sec. 54) and ecclesiastical law (sec. 57).

3 For example, the standards of canon law, - ecclesiastical disciplinary regulations unaided by or indeed even contrary to rules of the state.

${ }^{4}$ For example, standards of dueling recognized as binding to a certain extent in spite of general prohibitions. Str.G.B., secs. 207, 208. Note also the acquiescence in the commands of anti-social secret associations such as the maffia, camorra, etc.

${ }^{5}$ Thus by no means all the canonical impediments to marriage are recognized by the state; and in Germany no species of slavery is lawful, not even in favor of or against Africans. 
corporate regulations, customs and statutes, and even to foreign laws. It invests these standards, which are perhaps already obligatory in morals or religion, with the character of legal standards, by means of its sovereign power. It directs its courts to establish these rules as the basis of legal standards. ${ }^{1}$

It may also lay the duty of application within its domain, of standards not of its own expression, upon tribunals under its protection ${ }^{2}$ and not having state functions. Accordingly, the existence of customary law, ecclesiastical law, or autonomous law does not involve an opposition to the political character of law in general and the administration of justice.

The same is true of international law. It requires the recognition of the state, or at least of the participating states, as law-not in an individual case of conflict, but in abstracto considered as a standard for the defense of common interests and for the limitation of the individual interests of the states. It exists only among and for the several states. It is therefore, conceivable that the state may not be able to deny a recognition to certain commands and prohibitions not emanating from itself, even though they may be directed against itself, but must admit them either expressly or tacitly for the sake of its own existence and fundamental law.

What commands or prohibitions the state will invest with the attribute and force of legal standards is a matter of political discretion. This discretion determines what interests it will elevate to the level of legally protected

1 The German Empire recognizes Turkish, Chinese and Arabian custom by means of the provisions of sec. 40,R.G. of April 7, 1900, relating to consular jurisdiction, and sec. 3 Schutzgebietsgesetzes of Sept. 10, 1900, within the limits of arts. 30 and 31 , Einf. G. z. B.G.B.

2 Thus the recognition of patrimonial jurisdiction and the privileged jurisdiction of corporations. 
interests and what means it finds suitable for their protection. ${ }^{1}$

Sovereignty is manifested by this freedom of choice of its own interests as legal advantages and the application of means for their protection. The state, while not omnipotent, is yet legally independent of any power superior to it. That this legal independence is not political omnipotence is shown by the actual dependence of the activities of the state upon agencies which the state must take into account; since its measures, though unalterable, are influenced by them in execution. The law-generating state-the dominant social organism in its capacity of creating legal standards-is thus also actively dependent upon influences lying beyond its power. This view ${ }^{2}$ of the relation between legislation and the legal system is the view which practical men and statesmen in all ages must share. It may be called the opportunist view.

There are, however, two other conceptions of this relation. The first is that of the law-of-nature school (and within it, the moralistic school), which assumes that legal standards are immutable laws. Legislation may approximate, but may not contradict them. This view supposes the same relation between fixed legal standards and legislation as between human acts and Platonic ideas.

The second notion is that of the romantic (or, in a narrower sense, the historical) school, according to which law is not made (as the practical man supposes), nor yet is fixed (as the law-of-nature school assumes), but grows - that is, it transforms itself, according to necessity, without the need of legislation. It is appar-

${ }^{2}$ Thus, in Germany a new interest of the state has been created by the protection of carrier pigeons which are used in war. See R.G., May 28, 1894 (Gareis, Reichsgesetze, No. 192).

${ }^{2}$ Sec. 3, III, the relation of politics to the science of law. 
ent that, in this view, custom and science have the greatest influence.

According to the historical school as well as the opportunist view, there are three factors in a state establishment of law:-

1. The object and the ends of the state. In this respect, great variations in individual states are, of course, conceivable, and are necessary. By abstraction alone no generally valid conception of the objects of the state with a concrete legal content can be attained. ${ }^{1}$ The history of states and their comparative survey, however, exhibit three objects in every state, no matter how primitive or developed.

(a) Every state must have legal standards for the establishment of an organization through which the internal and external expression of the will and power of the state are made possible. This is true even though this organization be based on a traditional or customary recognition of a petty chieftain, a popular assembly or similar agency. In that the state is legally organized there must exist in all cases a constitution and a constitutional law.

(b) Military power is an equally indispensable legal advantage of the state. This is necessary to the maintenance of the characteristic attribute of the state, namely, its legal independence. It is necessary for protection of all its other legal advantages and functions, even by resort, if necessary, to the extremest force. There never was and can not be a state without an army, a military law and a body of legal standards by which a military organization is based on a system of rights and duties. This is true whether it be only military power involved in the authority of a chieftain, on one hand, or is based on military duty of those capable of bearing arms, on the other.

'Cf. Holtzendorff, Rechtsenzyklopädie, International Law, p. 847. 
(c) Finally, standards are necessary and universally existent, by which the relation is legally regulated between persons and things under all conditions. ${ }^{1}$ The right of ownership, whether it be individual, collective or communal, must be established.

2. Another esisentially influential factor in the development of the legal system is morals, or the force of powerful ethical notions held by a body of persons among the people, or at least among persons exerting an authority in the development of law. These ideas, historically considered, are as follows:-

(a) Family. $^{2}$ The necessity of some regulation of the relation of kindred, and the necessity of a duty in the nurture of children, are pre-eminent and universal. The legal standards grounded on this ethical foundation concerning spouses, parents, and children, however primitive they may be, form another basis of private law; the first being that of ownership ( $1(c)$ above).

(b) Collective revenge ${ }^{3}$ (Kollektivrache) and atonement (Sühne), both as ethical notions considered as reacting against wrongs and discords. These notions are ethical in so far as they are not the peculiar measures of the individual, as in private revenge (Privatrache). They are ethical impulses with the specific object of realizing the betterment of humanity. Social revenge (Gemein-rache) and atonement are in this, the ethical signification, the basis of criminal law.

(c) A variety of other ethical notions, or social institutions based on ethical ideas, leading to legal advantages, to protection and to regulation, as they may

${ }^{1}$ Cf. Bernhöft, in Z. f. vergleich. Rechtswiss., Bd. I, p. 18; Dargun, Ursprung und Entwickelungsgeschichte des Eigentums, ibid. Bd. V, p. 1; Oncken, Aristoteles I, 192.

${ }^{2}$ See Bernhöft, in Z. f. vergleich. Rechtswiss., Bd. II, p. 270.

${ }^{3} C f$. v. Liszt in $Z$. f. d. gesamte Strafrechtswissenschaft, Bd. III, p. 7.

Social instinct being accepted, collective revenge no doubt springs from it. There may be noted in this connection the decisive feeling of approbation or displeasure of society regarding acts which are beneficial or hurtful. 
require. These ideas are of different content among different peoples, as, for example, among Indo-Germanic peoples, the idea of hospitality (Gastfreundschaft), the affirmation of truth by invoking the Deity, the oach, etc. ${ }^{1}$

3. Lastly, the legal system is essentially influenced by the qualities of its elements, - that is, the nature of the land occupied and the people who constitute the state. Legal standards, consequently, depend on climate, ${ }^{2}$ geographical situation (mountains, seashore, etc.), national character, national predisposition, the leading occupation of the people, their history, customs, morality and similar influences. Economic considerations and the necessities of society, which in turn affect the legal system, also in part at least depend on these influences.

However different may be the form of the legal system as it is influenced by the forces operating upon it, yet the method of its operation, its means and immediate object are universally the same. Legal standards universally limit freedom of choice. The unlimited broad domain of unrestrained acts is divided up into limited legal spaces within which persons and communities are dominant as legal subjects. These legal spaces are spaces of freedom in which there is limited but protected volition. Legal advantages are thereby created out of interests. Legal relations are accordingly created within the domain of protected freedom from the facts and necessities affecting human existence.

It should be one of the objects of legal order, in the drawing of limitations by law and the establishment of

'See Bernhỏft, loc. cit., pp. 272, 274.

${ }^{2}$ A sociological influence has even been ascribed to good and bad weather. See Edwin Grant Dexter (Illinois), Weather Infiuences, London, 1904. [Montesquieu asserted that England had a high suicide rate on account of its fogs, but investigation appears to have disclosed that England's percentage of suicides was lower than in any other European country.] 
such limitations by means of commands and prohibitions, that they be suitable. There should be a due proportion between means and end which will justify the reasonableness of legal order. This requisite shows that an abstract uniformity of the legai standards of all countries and in all ages is an impossibility. It is an ideal not to be striven for, since such abstract standards would be repugnant to reasonable acts without regard to the prerequisite adaptability of means to ends.

In the establishment of legal limitations upon acts, it is an ideal which must be adhered to, that these limitations be so drawn that they allow to all persons the greatest possible freedom, and at the same time afford the greatest security for order and the attainment of the destiny of mankind. This is an ideal which can be attained only relatively in the proportion that individual ends can be measured by adequate means, and which will hardly ever be realized. The legal system which answers these requirements will not fail to evoke a condition of contentment which expresses, on one hand, harmony with the legal sense of the people and a virtue of justice among individuals, and, on the other, the purposes and efficiency of law.

By the statement of the dominant position of the state in the creation of the legal system, it is not to be understood that within the domain of one state only one legal standard may be authoritative with reference to one and the same legal institution; or that every legal regulation, or every legal standard, must have currency throughout the whole state; nor that such legal standard may have validity only within one state. It is possible, on the contrary, that-

1. Various legal regulations with reference to a legal institution may be current within the domain of one and the same state. For example, marriage 
property $^{1}$ has different legal standards in different parts of Germany.

2. One legal standard may be authoritative in the domains of more than one state.

If a number of states have an identical law, the validity of this law will rest upon the authority of each state, but the source expressing the legal rule may be the source of just one particular state, or the common source of all states having similar legal standards. In the latter case where the law is the same in a number of states, it is called common law (Gemeines Recht). Thus the codified law of Justinian became common law by reception ${ }^{2}$ in Germany in the Middle Ages. From a single source it became operative as unified customary law in all the different domains of Germany at the same time.

Law arising from particular sources in individual states is called special law (Sonderrecht) or particular law (Partikulares Recht) in contradistinction to common law. Coincident or similar particular law is sometimes called general law $^{3}$ (allegemeines Recht). Particular law has only a very limited scope, existing, for example, as particular law in a particular municipality (Stadtrecht), as local law (Lokalrecht) or as local custom (Ortsusance). Yet it is possible that particular law may have currency in more than one state, as when, for instance, the original domain in which it had currency is politically divided among two or more states.

The possibility of such legal division and geographical tearing asunder of legal systems may raise the difficult question as to what law, of the different laws coming

1 Güterrecht. Sec infra, sec. 31.

${ }^{2}$ Sohm, Institutionen des römischen Rechts, sec. 1.

${ }^{3}$ For example, the General German Bills of Exchange Code (1847) and the General German Commercial Code (1861), which were formulated in the time of the German Bund through concerted deliberation, and which were afterwards adopted by separate legislation of the individual states of Germany. 
under consideration, is to be applied. This question is not one of difficulty when one of two legal regulations in question has only subsidiary validity, or when it is valid only to the extent and so far as the other has no provisions covering the ground but contains lacunce. The Roman law thus had in Germany only a subsidiary or auxiliary validity to the Landrecht of Bavaria, Württemberg, etc.; apart, of course, from those German provinces in which it was altogether and completely excluded, as in the domain of the Prussian Landrecht, the French code and the Saxon civil code. Modern German imperial law, on the contrary, is absolute general law and is exclusive of contrary Landesrechte. ${ }^{1}$ Aside, however, from this class of cases, where one of the conflicting laws is subsidiary, and therefore in cases of coincidence of two absolutely current laws, other standards must determine the concrete settlement of the conflict.

Three kinds of collision of conflicting legal standards are to be distinguished:-

1. Territorial, or geographical collision; ${ }^{2}$ as, for example, the conflict of German and Russian laws in a German marriage of Russian subjects; or a contract of sale made by letter between a German at Hamburg and an American at New York, stipulating for delivery at Havre and payment at London. Which law shall govern? When the private law of two or more states is in question, the body of rules by which these questions are answered is called international

1 Art. 2. Imperial Constitution, April 16, 1871, provides: "Within the domain of this confederacy, the empire shall exercise the right of legislation, according to the provisions of this constitution, and to the effect that the imperial statutes shall have precedence over state statutes. Imperial statutes shall derive their obligatory force by imperial proclamation, which shall be made by means of a legislative bulletin. In so far as the published statute does not provide otherwise, statutes shall become operative on the fourteenth day after the respective bulletin is published at Berlin."

${ }^{2}$ See infra, sec. 13. 
private law. It is called conflict of laws when within one state two or more laws come into collision. ${ }^{1}$ In opposition to the view of the early Middle Ages grounded on a principle of personality (Personalitatssystem), these rules form a system which has its foundation in the principle of territorial sovereignty,-that every state will apply foreign law only through the authoritative administration of justice of its own law and its own judges, and only in cases particularly admitted by its own territorial law.

2. The temporal conflict is another kind of collision of legal standards of different states or of the same state; as, for example, the retrospective or prospective operation of the German Civil Code with reference to marriages celebrated prior to Jan. 1, 1900; and

3. Generic collision; as, for example, a collision of particular (special) law and general law, as in the case of the German Commercial Code on one hand and the German Civil Code on the other. As to this the provisions of the imperial introductory statutes to these codes are decisive. For further example, the conflict of particular and common law, as in the case of Prussian law on one hand and German common law on the other.

${ }^{1}$ Cf. art. 7 to 31 , Einf. G. 8. B.G.B.; also Gareis, in the Deutsche Revue, III (1878), p. 128, and I (1877), p. 140. 


\section{SECTION 9}

\section{SOURCES OF LAW $^{2}$}

The expression "source of law" is ambiguous. The state may be regarded as the fountain of all law, in the sense previously noted. By "sources of law" may be understood the writings, documents, records or literary monuments of the law which furnish a knowledge of legal rules. Possibly, also, a matter of fact with which a legal right is connected may be regarded as a source of law; as, for example, the right of inheritance arising through birth or death. According to another view, a source of law may be the social sense, or impulse to law of the people, and those tendencies in man and society which were designated as roots of the law.

In a technical sense, a source of law is the cause producing a legal rule,- - the causa efficiens of the standard established.

The starting point of a legal rule is the necessity for legal order. This alone is the primal source of law. It is necessary, however, that the rules evoked by necessity be expressed. It does not satisfy the necessity of law that there be law resting on surmise, feeling or opinion, even though the opinion is general. Limitations on freedom of will require an expression of law, or legisla-

1 Salkowski, Inst., sec. 3; Sohm, Inst., sec. 7, II.

[The ambiguities of this expression may also be thus classified: A source of law may be-

1. Formal (after Salmond): the will and power of the state.

2. Legal: the authoritative agency of expression of a legal rule (courts, etc.).

3. Historical: non-authoritative agencies of expression of legal rules (private commentary, etc.).

4. Literary: the literary monuments (statute books, books of cases, etc.).

5. Causal: the facts, occasions, causes, conditions or influences which generate legal standards]. 
tive (positive) intervention. The establishment or expression of legal rules for human conduct is always an expression of human will, and is, of course, always the will of a community. ${ }^{1}$

1. This social organism is either the state,- the governing social organism to which every legal rule owes its necessary authority, but by which only that class of legal rules which are called legislation is established,or it may be--

2. Another social entity, which, though not the state, expresses legal rules necessary for the regulation of external relations:

(a) Either in declarations which aim at the establishment of rules in as direct and conscious a manner as the declarations of the state which are called statutes are made. So-called autonomous law, the statutes of autonomous corporations, etc. (see sec. 12), are of this class.

(b) Rules of a non-governing social organism having a validity within itself responsive to its necessity of law, but not having a direct and conscious effect in the establishment of new legal rules aimed at conduct.

${ }^{1}$ Even when legislation is the function of a single person, it is the expression of the will of the community. The absolute monarch expresses the will of the community.

[To be applicable to the Anglo-American system of law, the use of the term "legislation" requires a wider extension than the text indicates. As employed it does not embrace the de facto creation of law by the courts. The - declaratory theory, however, shuts its eyes to the facts, and assumes that the courts merely declare pre-existing law and do not create it. Legislation as the creation of law may arise in three distinct ways: 1. It may be an abstract antecedent declaration of standards. This is legislation in a strict sense, and is what Austin calls direct legislation; thus, statutes enacted by a legislature. 2. It may be an abstract subsequent declaration of standards applied to a state of facts calling for such declaration and adapted for the future. The law-making function of English precedent illustrates this species of legislation. Austin calls it indirect legislation. 3. It may be a contemporaneous concrete application of standards: thus, custom.

In European countries precedent has had simply a persuasive influence similar to the non-authoritative position of private commentary. While the authority of precedent has in late years increased in Europe, it has hardly yet reached that position where it may be regarded as a kind of legislation.l 
Customary law (sec. 10) and law arising out of necessity (notwendiges Recht) (sec. 12) are examples.

These kinds of law may arise-

(a) In the community--that is, among the people considered as a homogeneous unity without regard to their organization for purposes of the state, and especially in an economic unity of the community. The community, as it discovers by its own observation necessities which it seeks to satisfy by its own force, also attempts to carry out the legal conceptions generated within itself.

(b) In portions of the community organized according to station, or based on other distinctions having a social operation. They may find in their organization necessities of their own, and accordingly legal necessities peculiar to such organization, which they attempt to satisfy. Customs peculiar to parts of the community, or particular customs, arise in this way.

(c) In the community of governing social organismsthat is, the community based on the common interests of states. The rules of international law flow from this community.

The authority of the state, however, lends to all of these rules the character of legal rules. 


\section{SECTION 10}

\section{CUSTOMARY LAW}

Custom clearly exhibits the necessity of law. It may exist throughout a community, in a part of a community, or in a community of states with common interests. Custom may generate rules by which human conduct is limited and regulated. The state may and in certain cases must lend its recognition to customary rules. Rules originating in this manner and not derived from legislation are called jus non scriptum, " even though, perchance, they may have been recorded by private persons.

In order that a rule of customary law may exist, it is necessary that there shall have been a plurality of acts in which no deviation is traceable. This is prerequisite before a rule or standard may be recognized; and the rule must not be opposed to the recognized laws of morality or of reason. ${ }^{2}$ In that the rule so formulated must be adequate to the necessity of law perceived by the community, its relative conformity to reason-that is, its correspondence with the views of the time of

I D. II, 6, I (Ulpian). Hoc igitur jus nostrum constat aut ex scripto, aut sine

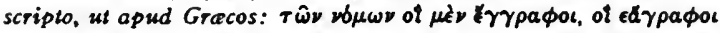

2 The controversies regarding the ground of validity. the origin and exigence of customary law, can not be here discussed. Cf. Windscheid, Pand., secs. 15-18; v. Brinz, Lehrb. der Pandekten, sec. 19: Dahn, in Behrend's $Z$.. Bd. IV, p. 553; G. Fr. Puchta, Das Gewohnheitsrecht (1828-1837); G. Beseler, Volksrecht und Juristenrecht (1843); H. Thöl, Volksrecht, etc. (1845); and the remaining literature noted in Kraut, Grundriss zu Vorlesungen über das deutsche Privatrecht, 6th ed., rev. F. Frensdorff (1886), secs. 20, 21. The possibility also of custom derogatory to statute must be admitted: cf. Entscheidungen des Reichsgerichts in Zivilsachen, Bd. 37, p. 179 . With regard to the modern position of customary law with reference to the German Civil Code and the German Commercial Code, see Gareis, Das. B.G. B. (Giessen Emil Roth, 1898), XXIII, XXIV, and Gareis, Dewisches Kolonialrecht, 2d ed. (Giessen, Emil Roth, 1902), p. 76, note 1. 
origin, etc.-is presupposed as the condition of a rule of customary law.

The customary law of a people is as a rule of earlier origin than its legislation, with which it is generally of equal validity. ${ }^{1}$ It extends back occasionally to ages in which rules of law were not theoretically separated from rules of morals, ethics and religion. It extends back even to times when the legislative function was not yet distinguished from judicial power, and when the judge himself created law.

Legal history shows universally that from the moment that the dominant social organism is conscious of its mission of providing for legal order, it expressly declares standards for those individual cases in which a necessity is exhibited of a clear or a new rule for the protection of public or private interests. Such primitive legislation, sprung from the necessities of the moment, is necessarily unsystematic, and must leave to custom a wide range

1 "The rule of conduct is transcendent law, whether it be taught in the revealed texts or in the sacred tradition; hence a twice-born man who possesses regard for himself, should be always careful to (follow) it."-Manu I, 108. With regard to the historical side of custom, see Leist, Gräcoitalische Rechtsgeschichte (1884), pp. 515, 760. Language, also, is or becomes a matter of custom, and has its own laws. Philologists know the laws of the formation of languages. but do not make them; they are simply principles, like those of the natural sciences.

Ex non scripto ius venit, quod usus comprobavit. Nam diuturni mores consensu utentium comprobati legem imitantur.-Inst. 1, 2, 9.

Inveterata consuetudo pro lege non immerito custoditur et hoc est ius, quod dicitur moribus constitutum. Nam quum ipsce leges non alia ex causa nos teneant, quam quod judicio populi recepte sunt, merito et ea, quce sine ullo scripto populus probavit, tenebunt omnes; nam quid interest, suffragio populus voluntatem suam declaret, in rebus ipsis et factis? Quare rectissime et illud receptum est, ut leges non solum suffragio legislatoris sed etiam tacito consensu omnium per desuetudinem abrogentur.-Dig. I, 3, 1.

With respect to custom in German legal history, see Brunner, Deutsche Rechtsgeschichte, Bd. I, pp. 109, 254, 282; Gierke, Jugend und Altern des Rechts (Deutsche Rundschau, 1879); also his Deutsches Privatrecht, Bd. I (1895), p. 159; Geschichte und Quellen des deutschen Rechts, in v. Holtzendorff's Rechtslexikon, Syst. T., sec. 3; v. Amira, Über Zweck und Mittel der germanischen Rechtsgeschichte, 1876, pp. 29, 40; O. Stobbe, Geschichte der deutschen Rechtsquellen $(1860,1864)$; also his Hdbch. des deutschen Privatrechts, sec. 21.

[In the English law all custom gives way to legislation. Local (immemorial) custom may, however, derogate from the common law.] 
of competence. This is shown all the more as private records of customary law are frequently employed in practice in case of the deficiency of statute, and are used in the same manner as statutes. Such records meet the necessity of fixed legal standards, and occasionally lead to actual codification. ${ }^{2}$

Even when legislation has attained an extended development, and a competence for systematic regulation of the relations affecting conduct, yet there will remain open a wide domain in which customary law may have a function. Modern law, accordingly, still recognizes a great variety of custom-made standards. Frequently the latest of such standards are the most appropriate, as in the case of the custom of merchants.

Customary law is not formulated by the state, but by the community. It springs from the people in their

1 The authoritative sources of ancient unwritten law of Germany are-

I. For the first period of German law (prior to the end of the ninth century):-

1. Commentaries of Roman authors; see Kraut, Grundriss zu Vorlesungen über das deutsche Privatrecht, 6th ed., rev. by F. Frensdorff (1886), sec. 4. 2. Collections of formulas; see Frensdorff-Kraut, op. cit., pp. 12-14. 3. Records; see Kraut, loc. cit., p. 12, and in particular H. Brunner, $Z$ ur Rechtsgeschichte der röm. u. germ. Urkunde (1880).

II. For the period after the dissolution of the Frankish empire to the end of the Middle Ages:-

1. Law books: Sachsenspiegel (speculum Saxonum), written about 1230 (see Frensdorff-Kraut, pp. 39-43); the Spiegel of the Germans, written after the Saxon Spiegel (see Frensdorff-Kraut, p. 48); the Schwabenspiegel, between 1273 and 1275; and works of practice and instruction.

2. Records, and judgments of assessors (Schoffensprüche); see Frensdorff-Kraut, pp. 55 to 60 . With reference to the law treatises see v. Amira, op. cit., supra, sec. 5 , note 1 .

III. The prodigious structure of customary law in Germany was due to the reception of Roman law by way of custom. The Justinian legislation attained in Germany by this reception a validity in modified form (usus modernus). See Salkowski, Inst., sec. 19. It had authority as subsidiary law until Jan. 1, 1900, in those provinces which did not possess an exclusive territorial civil law. It did not obtain, therefore, in Prussia, Saxony and the territory of the French law. The Roman law was deprived of force by the Civil Code, or more precisely, by the statute introductory thereto. (Art. 55 of the introductory act to the Civil Code (see also art. 2) provides that the private laws of the states are repeated unless otherwise stated in the Civil Code or the introductory act.] 
economic unity, or from a part of the community. It is. responsive to social necessity, and has its validity for that reason. Finally, it may proceed from a community of states. The authority of customary law as a legal standard is due, however, only to the dominant social organism. 


\section{SECTION 11}

\section{LEGISLATION}

Legislation is a declaration of the dominant social organism by which a legal standard is created or imposed.

The making of such declarations is the province of the state, by virtue of its sovereignty of legislation. As slown above, legal standards transform relations of fact into jural relations. In this transformation freedom of choice is legally limited and therefore legally protected; and legal advantages are created. ${ }^{1}$ As compared with customary law, the activity of the state in legislation has a double aspect. It declares the standard from within itself, and invests this declaration with legal character. It also elevates its declarations to the level of a standard, in that it authoritatively interposes its power for the maintenance of legal order.

Legislation is created not by the community or the people in their economic activity, but by a legally organized people,- - the state,-or the governing social

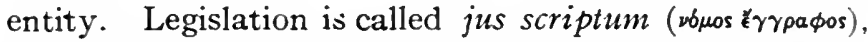
even though it is not written down, and even though it becomes legally binding only by verbal decree.

No state can be maintained without legislative activity; but universally, so far as legal history affords information, legislatively established standards are subsequent in time to customary law. The earliest expression of legislative power does not relate to the whole legal system, but only to isolated, urgent questions, the solution of which at the moment the interest of society, or individuals, appears to require. In this manner de-

${ }^{1}$ Cf. Gareis, Allg. Staatsrecht, sec. 44. 
tached penal regulations come into existence, the object of which is security of the community, the protection of its military interests or the security of family and ownership. Legislation takes on a comprehensive character when it undertakes the codification into statute of the theretofore existing customary law. ${ }^{1}$ It attains its summit when it systematically constructs the organization of the state on a legislative basis, and at the same time systematically places the totality of the elements of the state under legal protection.

The following steps may be distinguished in legislation: Initiative (Initiative), establishment of its text (Redaktion des Textes), promulgation (Promulgierung), legislative sanction (Gesetzesbefehl), order of publication (Publikationsbefehl), and publication. ${ }^{2}$

[In Germany the right of legislative sanction resides in the Bundesrat, and not, as might be supposed, in the emperor; the latter has no veto.]

There are many varieties of legislation, according to the agencies which are legally authorized by the state to co-operate in the exercise of the legislative function, which declare the standards, or issue the legislative command.

I. Roman $1 \mathrm{aw},{ }^{3}$ according to the agencies by which it was established, is divided into-

1. Leges and plebiscita (popular laws, as the leges XII tabularum, 457 and 450 B. C. ${ }^{4}$ );

2. Senatus consulta (S.C.ta);

\footnotetext{
1 Thus the oldest known Roman laws, the leges duodecim, and the German leges barbarorum, contained a predominance of antecedent customary law which was protected against failure of memory and similar nullification by being put into the form of legislation.

${ }^{2}$ Cf. Gareis, Allg. Staatsrecht, sec. 70.

${ }^{3}$ Franz Leonhard, in Birkmeyer's Enz., p. 82; Salkowski, Inst., secs. 7-12. For an explanation of the method of citation of Roman law see Salkowski, ibid, sec. 16, pp. 55, 56. Regarding the evolutionary stages of Roman law see in particular Sohm, Inst., secs. 10-18.

4 Leonhard, loc. cit., p. 81.
} 
3. Edicta magistratuum (jus honorarium; for example, the edicta cedilit. protor);

4. Constitutiones principum (imperial statutes distinguished as edicta, mandata, decreta, and rescripta; the last according to their form, either as adnotationes or subnotationes, epistole, sanctiones pragmatica);

5. Responsa prudentium; ( $c f$. the so-called law of citations: Codex Theodos.de resp. prud. 1, 3, 1, 4, Theodosius and Valentinianus, 426 A. D.). ${ }^{1}$

The legislation of the emperor Justinian (reg. 527-565), which became current as customary law in Germany in the Middle Ages by reception, and which had a subsidiary validity in a large part of this country, until Jan. 1, 1900, included, apart from the compilation in the corpus juris civilis of the legislation of earlier emperors: (a) the Institutes (which were intended as a book of instruction) published Dec. 30, A. D. 533; (b) the

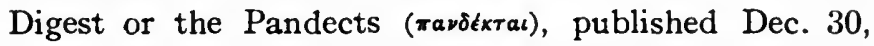
A. D. $533 ;$ (c) the Code (repetite prelectionis), published Dec. 29, A. D. 534; and (d) the Novels (novella constitutiones).

II. The written law of the earliest period of German legal history is found in-

1. The so-called Volk laws (leges barbarorum). Of these the most important are: the tribal law (Stammesrecht) of the Salic Franks (lex salica), probably dating between A. D. 496 and 511; the Volk laws of the Ripuarian Franks (lex ripuaria), arising probably out of two enactments both of A. D. 596; the pactus Alamanorum, two records of the earliest Volk laws of the Swabians, the first of the year A. D. 600 , and the second, A. D. 718 ; the leges Visigothorum, an official collection of kingly statutes of different years between A. D. 466 and 687; the lex Bajuvariorum, the Volk laws of the Bavarians,

${ }^{1}$ Ibid, p. 92 
originating probably about A.D. 750; the lex Burgundionum, dating about A. D. 500; the lex Saxonum, the lex Angliorum et Werinorum, the lex Frisionum, and the local law (Gaurecht) of the Hamaland Franks [lex Francorum Chamavorum] and others, enacted probably about A. D. 802.1

2. The capitularies ${ }^{2}$ of the Frankish (Merovingian and Carolingian) kings and their representatives (majores domus).

III. The written law of Germany from the end of the Carolingian empire to the end of the Middle Ages is found in-

1. Imperial statutes; ${ }^{3}$ for example, the Golden Bull of A. D. 1357; the regulation for public peace, and the statute regarding the earliest supreme court of judicature, both of A. D. 1512; the imperial regulation of the notarial office; and the regulation of penal justice of Charles V. (constitutio criminalis Carolina, A. D. 1532).

2. Territorial statutes; for example, the landrecht code of Ludwig of Bavaria of 1346 (revised in 1515, 1616, and in 1756 as the Bavarian Civil Code); the Solmser Landrecht (code drawn by Joh. Fichard, 1571), etc.

3. Numerous municipal statutes; for example, the Augsburg Stadtrecht (1276); the Freiburg (Breisgau) Stadtrecht, of 1520, drawn by Ulrich Zasius; the Berlin Stadtrecht (1397); the Bremen Stadtrecht (1304); and the Frankfurt a. M. Stadtrecht (by Joh. Fichard, 1578).

\footnotetext{
${ }^{1}$ See v. Amira, op. cit., with reference to Stammesrechte. [A convenient and interesting work in this connection will be found in the book of Guy Carleton Lee, Historical Jurisprudence (The Macmillan Co., 1900).]

2 See Alf. Boretius, Capitularia regum Francorum, in Mon. Germ. histor. Leg., sec. II (1883). Cf. the land laws of Charlemagne (Capitulare de villis vel curtis imperii) with an introduction and notes to the text by Karl Gareis, Berlin, 1895.

${ }^{3}$ With reference to the form of these statutes see v. Schulte, Deutsche $R$. Geschichte, sec. 97, and Gareis, Allg. Staatsrecht, sec. 24 (pp. 62, 63).
} 
4. Laws regulating the imperial household and the officers of the court; for example, the Wormser Dienstrecht (1024); and the Basler Dienstrecht (thirteenth century).

Imperial law, municipal law and Landrecht continued to be concurrent sources of written $l^{1} w^{1}$ in Germany even after the Middle Ages.

IV. In the period following the Middle Ages until the nineteenth century, written law in Germany developed chiefly in the individual provinces within the empire, which constantly attained a greater independence and range of activity. Thus the organization of the Prussian state with Brandenburg as its nucleus was brought about by legislation; and at the end of the century (1794) the allgemeines Landrecht of Prussia came into existence. In a similar manner there was formulated the Bavarian Landrecht of 1756.

In modern constitutional states, and particularly in the constitutional monarchy of Germany, jus scriptum is classified as follows:-

1. Statutes (Gesetze) or laws in the narrow sense. ${ }^{2}$ This embraces those laws established as legal standards by the concurrence of all legislative agencies, consisting of the government and the popular assembly, the latter of which is either unicameral or bicameral; and

2. Regulations, or legal standards established by the head of the state or the government without the concurrence of a popular assembly.

In the German Empire as now constituted, the difference between these legal standards exists in a double

\footnotetext{
1 With reference to the German historical sources of written law see Stobbe, Geschichte der deutschen Rechtsquellen I (1860): H. Brunner, D. R. Geschichte, also by the same author Grundzüge der deutschen $R$. Geschichte (2d ed., Leipzig. Duncker and Humblot, 1903), sec. 62, p. 242; Frensdorff-Kraut, Grundriss, sec. 2: Gengler. Germanische Rechtsdenkmäler (1875); and Richard Schröder, $D$. R. Geschichte (4th ed., 1902).

${ }^{2}$ Laws (Gesetze) in the widest sense, see art. 2, Einf.G. z. B G.B.
} 
aspect. There are, on one hand, imperial statutes and imperial regulations, the latter consisting of imperial ordinances and ordinances of imperial boards. On the other hand, there are laws of the states composing the empire involving a similar distinction.

The competence of legislative agencies and legislative procedure is determined by the law of each state. ${ }^{1}$

With reference to the distinction between general and special law see above, sec. 8. Modern imperial law is not subsidiary general law but absolute general law. ${ }^{2}$

1 The constitution of the German Empire of April 16, 1871, provides with reference to the creation of written law for the empire:-

Art. 5. Iniperial legislation shall be created by the Bundesrat and the Reichstag. The vote of a majority of both assemblies is necessary and shall be sufficient for the enactment of an imperial statute.

Art. 17. The certification (Ausfertigung), publication (Verkündigung) and administration of imperial statutes shall attach to the emperor. The order and decree of the emperor shall issue in the name of the empire and shall bear the countersignature of the chancellor, who shall thereby attest the validity of the statute.

Art. 11. The presidency of the Bund shall attach to the king of Prussia, with the title, German Emperor. The emperor shall represent the empire in international relations, and shall have the power in the name of the empire to declare war and to conclude peace, to make treaties with foreign states, and to accredit and receive envoys. The concurrence of the Bundesrat is necessary for the declaration of war in the name of the empire unless the territory of the country is invaded. In so far as agreements with foreign states touch such matters as are within the purview of legislation according to Art. 4, the concurrence of the Bundesrat is essential for their conclusion and the approval of the Reichstag for their validity.

Act 6. The Bundesrut shall consist of the representatives of the Bund.

Act 20. The Reichstag shall be elected by a general, direct and secret vote.

Art. 23. The Reichstag shall have the right to formulate laws within the competency of the empire, and may as to petitions addressed to it recommend them to the Bundesrat or the imperial chancellor.

[Members of the Reichstag are elected for a term of three years, and serve without pay.]

${ }^{2}$ Concerning the relation of the German Civil Code to other imperial laws see Einf.G., art. 32-55; for its relation to state laws, see ibid., art. 3, 4, 55-152, 218. 


\section{SECTION 12}

\section{OTHER SOURCES OF LAW}

Aside from legislation and custom, both of which are created as legal sources by the authority of the state, the following sources have a legally generative force:-

(a) Jural necessity (Rechtsnotwendigkeit) generates rules which proceed from the state just as in the case of customary law. These rules have their origin in the community, as distinguished from the state. They are recognized by the dominant social entity and form jus necessarium. While every important jural necessity which prevails as a necessity of the community within the state is satisfied by legislation, if not by customary law, it has its chiefest function and importance as a source of positive law in that community, for which, as such, state legislation does not exist-in the community of states. Necessitas juris is one of the leading sources of international law. ${ }^{1}$

(b) Autonomous law, arising from a subordinate power of making law, vested by the dominani community, the state, in other social aggregates within its domain. This power may reside in such parts of the governing or dominant community as have been previously themselves dominant and which have formerly had legislative power, or custom. Autonomous law, of course, is indulged by, and is subordinate to, the law of the dominant community. This power may also reside in privileged corporations, provinces, colonies, etc. The law of such communities or of such parts of communities is nevertheless subordinate to the authority of the state,

'See Gareis, Inst. des Volkerrechts, sec. 9; also infra, sec. 54. 
and is called autonomous law. When such law is declared, then, as in the case of laws of the state, it is called statute law, or autonomous statute law. When it is not so declared, and consequently is analogous to customary law of the state, it is called observance, or autonomous observance.

According to present German law (and particularly the private law of the nobility), autonomous law appertains to the heads of the several states and their families, and to the princely house of Hohenzollern; to the former royal house of Hanover; the former house of the Electorate of Hesse; the house of the Duchy of Nassau; and the princely house of Holstein. It also attaches in a limited manner to the former imperial nobility and the feudal nobility. ${ }^{1}$

(c) The science of law. This is not an independent or a sovereign source of law. It can declare legal rules only under the dominion of one of the other sources. It is also destitute of that authority by which standards, derived from other sources of law, are sustained-that is, the sovereign authority of the state. But it possesses an appropriate authority in the power of truth and through the conviction of reason. It is employed and has its own peculiar force theoretically among authors and teachers, and practically among judges and lawyers. It declares legal rules which are already latent in existing legislation and custom, but which yet lack authoritative expression. ${ }^{2}$

${ }^{1}$ See Einf.G. z. B.G.B., art. 57 and 58, and R.G., March 25, 1904 (R.G.Bl., p. 149).

${ }^{2}$ See supra, sec. 3 ; cf. v. Brinz, Pandekten, sec. 19; Windscheid, Pand.. sec. 20; Stobbe, Handbuch des deutschen Privatrechts, secs. 24, 25; Cosack, Lehrb. d. deutschen bürgerl. R., sec. 11; Beseler, Deutsches Privatrecht, secs. 34-36; Dahn-Bluntschli, Deutsches Privatrecht, secs. 7, 8; and Gareis, Inst. des Völkerrechts, sec. 9. 


\section{SECTION 13}

\section{APPLICATION OF LAW (Rechtsanwendung)'}

The application of law is a generalization of a case in law (Rechtsfall) under a legal standard, in the same manner that the law itself is derived from generalization. Accordingly, the application of law requires the consideration of-

1. The legal standard; its content, force and range: the question of law itself (questio juris in the narrow sense);

2. The case in its relations of fact (questio facti);

3 . The generalization which arises from-

- (a) the answer to the legal question;

(b) the question of fact;

(c) the possibility of choice between a number of legal rules colliding either in point of time or space.

Facts are demonstrated by evidence, admissions, general knowledge, deduction, legal presumptions (presumptiones juris, also conclusive legal presumptions which exclude proof, or presumptiones juris et de jure), statutory rules of interpretation and legal fictions.

The question of the content, force and range of legal standards (questio juris stricto sensu) must be taken into consideration $^{2}$ in every form of legal application, whether in a judicially responsive (decisional administration of justice) or in non-contentious jurisdiction (see sec. 48, III), and whether in the application or jus scriptum or jus non scriptum. This distinction, however, must be observed that criticism as well as interpretation is far

${ }^{1}$ See Salkowski, Inst., sec. 5; Cosack, Lebrb. d. D. B. R., secs. 11-13.

${ }^{2}$ Cf. Adolf Stölzel, Schulung für die sivilistische Praxis, p. 229. 
more necessary in the interpretation of legislation than in the consideration of jus non scriptum.

The application of law is preceded by-

(a) Criticism (Kritik), or proof of the authenticity of the legislative text as a whole, and of every word in it. Criticism, therefore, is either selective (wählende Kritik), or conjectural (Konjekturalkritik);

(b) Interpretation (Auslegung), or the discovery of the legislative intent from the law, in which rules of construction or the principles of hermaneutics are employed.

Among the kinds of interpretation the following are to be distinguished:-

Classified according to the agency, interpretation is authentic if it proceeds through a sovereign legal source. Authentic interpretation may accordingly be legal (legislative $^{1}$ interpretation) or usual (customary interpretation);

Classified according to the means employed, interpretation may be either grammatical, logical or historical; Classified according to the relation between the verbal sense and the verbal expression, interpretation may be either extensive or restrictive.

Analogy governs legislative expression. It is the application of a legal rule to a situation not thought of by the legislator, or one which he could not, perhaps, have had in mind, but to which he would have applied the rule. Analogy is a correspondent application of a legal rule propter paritatem rationis. ${ }^{2}$

A choice may be necessary between two or more legal rules concretely in question when there is a temporal, territorial, or generic conflict or collision.

\footnotetext{
${ }^{1}$ Legal interpretation is also regarded as synonymous with authentic interpretation.

2 With reference to interpretation and analogy, etc., see Windscheid, Pand., secs. 21-26. [See also Pound, "Spurious Interpretation," in Columbia Law Review, vol. VIII (1907), p. 379.]
} 
(a) With regard to conflict or collision in point of time, the following rules apply: Lex posterior derogat legi priori, and lex posterior generalis non derogat legi priori speciali, except when lex posterior generalis radically abolishes a legal institution.

Retrospective operation of laws is exceptional and results only when expressly provided, or when the object of the new law can not be attained without retrospective effect. ${ }^{1}$

(b) In solving the question of the application of law with reference to its territorial limits, ${ }^{2}$ there must first be eliminated that class of cases, already noted, where one law is subsidiary to another. The legal maxim, "Local autonomy overcomes municipal law, municipal law overcomes territorial law, territorial law overcomes common law," 3 assumes that in each case the latter term involves a subsidiary position to the former. It assumes that the law set aside by a locally autonomous or private exercise of will (as particularly in the case of agreement) is never lex cogens vel prohibitiva but only lex dispositiva. In all other cases, in the question under consideration, the principles of conflict of laws, or socalled private international law, are determinative. ${ }^{4}$

${ }^{1}$ Cf. Einf.G. 2. B.G.B., art. 1, 153-218. With reference to the detail of the difficulties presented in the application of law from the standpoint of limits of time, see Roth, Deutsches Privatrech, sec. 50; Stobbe, Handbuch des deutschen Privatrechts, secs. 27, 28; Windsheid, Pand., secs. 31-33; Dernburg, Pand., secs. 43, 44; Hölder, Pand., sec. 16; Regelsberger, Pand., secs. 47, 48; and Cosack, Lehrb. d. D. B.R., sec. 13.

${ }^{2}$ See v. Roth, op. cit., sec. 51; Stobbe, op. cit., secs. 29-34; Windscheid, Pand., 34-36; Dernburg, Pand., secs. 45-48; Hölder, Pand., sec.. 17; and Regelsberger, Pand., secs. 39-46.

${ }_{3}$ "Willkür bricht Stadtrecht, Stadtrecht bricht Landrecht, Landrecht bricht gemeines Recht." [Each of these terms has a special historical significance in Germanic law.]

4See Savigny, System des heutigen röm. Rechts, Bd. VIII, pp. 8-367: Bar, Das internationale Privat-und Strafrecht; Brinz, Pand., secs. 22, 23; Cosack, Lehrb. d. D.B.R., sec. 12. Conflict of legal standards can only be obviated by examining and establishing their position with reference to every legal relation, and by seeking to determine in every legal standard the will of the 
(c) In cases of generic conflict of coexistent legal standards, their place is determined accordingly as they are absolute or subsidiary law, or special or general law. ${ }^{1}$

legislator with reference to such conflict: The rule of legislative interpretation affecting declaration of intention which serves to establish but not to create the content of a private expression of will (as in the case of agreement, where the parties have not made provision for a point in question) is distinguished from lex dispositiva as an instrument for supplementing the law. (See B.G.B., 130, 453, 2066; R. Stammler, Das Recht der Schuldverhältnisse (1897), p. 76.)

${ }^{1}$ Gierke, D. Privatrecht, sec. 22, I, p. 183. 


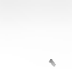




\section{PART SECOND}

\section{SYSTEMATIC CLASSIFICATION OF THE LAW}

\section{SECTION 14}

FOCAL POINT AND SURVEY OF THE LEGAL SYSTEM

I. In order to arrive at a systematic classification of the corpus juris, it is necessary to go back to interests. Interests, as already shown, are based on relations of persons and things (or only of persons). ${ }^{1}$ They are either interests of determinate persons or of communities. These interests may belong to both individuals and communities at the same time; interests of individuals being, however, of greater importance.

Man is endowed with the faculty of understanding and the capacity for working out the interests of society and harmonizing the impulses of egoism with sociality. This sense of law is derived from the basic principles of human reason.

Interests are of two classes:-

1. Special interests of individuals; and

2. Interests of the community.

Both of these classes of interests may have a material foundation; as, for example, the interest in subsistence. Both may have an ideal basis; thus, an interest in education. Interests become legal advantages when they are protected by law, the one class becoming the legal advantages of individuals, and the other the legal advantages of the community.

Interests of the community may be regarded in a double aspect, in the same way that, in the discussion

${ }^{1}$ See supra, sec. 5. p. 34 , note 2. 
of the sources of law, the twofold view of the community was of importance. By the term "community," may be understood-

1. The dominant social entity and its parts; thus, the empire, state, province, parish and other public corporations; and

2. Society and its parts, consisting of the people collectively in their economic relations, associated according to employment, rank, or otherwise, without regard to state organization.

The interests of these two classes of social aggregatesthe dominant governing community and the economic community-are not necessarily identical. It is conceivable that the state may have an interest, as such, in excluding, or placing a burden on, the importation of goods by prohibitive or revenue tariffs. Again, it may be conceived that both communities may have an interest in the same relation, considered as an object, but from different motives, and in unequal degree. Accordingly, there are legal advantages of the governing community, and legal advantages of the economic community. This fact, with the addition of legal advantages of individuals, allows of a threefold division of the law into private law, public ${ }^{1 a w^{1}}$ and social law. This follows to the extent that standards of law, either in the main, or exclusively, relate to interests of private persons, the state and its parts, or the economic com-

\footnotetext{
${ }^{1}$ (Public law (öffentliches Recht) is divided into Stoatsrecht (state law) and Volkerrecht (international law). Staatsrecht again is divided into Verfassungsrecht (constitutional law) and Verwaltungsrecht (administrative law). According to German usage Verfassungsrecht is called Staatsrecht in the narrow sense. Translation requires the use of the expression "public law in the narrow sense" to distinguish Staatsrecht from international law, and the expression "public law in the narrower sense" to designate constitutional law, according to the usage indicated. If it were not for the fact that interests of society apart from the state are not made one of the divisions of juristic classification, a further verbal refinement would be necessary. The use of "state law" for Staatsrecht. while persuasive on the ground of convenience, does not appear to have gained a position in our terminology. I
} 
munity and its parts, and to the extent that these respective interests are protected, and transformed into legal advantages.

II. In two respects, this triple division of law is insufficient. The international community, based on an association of international interests, is also legally protected. This is accomplished by standards which, so far as they are peculiar to the international association, are called International Law.

Again, the legal rules by which social interests are protected are in part no different from those which give legal protection to individual interests in private law ${ }^{1}$ considered as a means of protection of the community. On the other hand, also, the state takes as its province, not only the protection of its sovereign interests, as a governing community,-which is accomplished by public law in the narrow sense (Staatsrecht), - but also assumes to protect and in part to further social interests. By reason of the historical reception of social interests by the state, which assimilation resulted under the greatest variety of operating circumstances, it has followed that social law (Gesellschaftsrecht), (so far as it is not at the same time private law) has evolved alongside, in the name, and in the domain, of state law.

To a great extent, the means, by which genuine interests of the state which are not social interests-or at any rate are not such principally-are furthered and protected by non-private force, are of the same kind and operation as in the protection of social interests. For example, the coercive measures of the statutory domestic police, whether of preventive police security or positive-welfare administration.

1 This method of protection of social interests corresponds most nearly with the Manchester state or the legal state (Rechtsstaat) in the narrowest sense. Cf. sec. 41. 
The legal rules which have for their object protection of interests of the state and make public law in the narrow sense; those which are intended to protect and guarantee the interests of society and which form social law; and, finally, those legal rules through which an international community of interests is elevated to the position of a legal community in international law, are collectively in contradistinction to the standards through which private individuals are protected in their private or civil interests. The distinction lies in this, - that, in the first three cases, interests are involved which, in verbal opposition to private interests, must be called public interests. Therefore, the law which in such cases affords the contemplated protection of interests is called public law, or jus publicum.

III. The principal division of the corpus juris into private or civil law (jus privatum or jus civile), and public law (jus publicum), thus arises.

Inasmuch as social law, for the two reasons considered, has no definite position in the classification, public law is separated into-

1. Public law in the narrow sense (state law, Staatsrecht, jus publicum civitatum or alicujus civitatis), including also the standards for the protection of social interests. Social interests, while not completely embraced by this division, yet can not be separated from it;

2. International law (jus inter civitates, jus inter gentes, belli et pacis; see sec. 54).

Public law in the narrow sense, according to the leading interests and the chief functions which the state represents and furthers in its activities, is divided into-

1. Constitutional law, which includes the standards through which the stability of state sovereignty in its (a) organization and (b) elements is legally protected; and 
2. Administrative law, which embraces the totality of legal standards which govern the activity of the state in (a) legislation and $(b)$ administration (understood in a sense opposed to legislation and embracing all non-legislative state activities).

IV. The relation of the several parts of the law to each other in developed systems is variable. It is impossible to derive the proper scope of public law in the narrow sense (state law) as against private law abstractly either from the nature of law itself or from the nature of the state. The same want of uniformity in the appropriate line of demarcation appears in actual systems as is shown in the theoretical view - the political science of legislation (Gesetzgebungspolitik, de lege ferenda).

In ancient times, and in the Middle Ages, there were a large variety of matters, which we now consider as belonging to public law, which were embraced by private law. In earlier times these matters only indicated individual interests and not social interests. The adjustment of social conditions appeared more simple through standards of private law than of public law. Nevertheless, every state must recognize, and must have recognized from the beginning, a large number of standards as belonging to public law.

Constitutional law, and military law, even though in the most primitive form, and universally, the rudiments, at least, of private law, as such, must have been recognized by the state. But the residue of the law and its details present an extraordinary diversity of conception and practice. There is frequently a lack of distinction between public and private law, and universally so in lower stages of civilization. Interests of the community, which though imperfectly understood ${ }^{1}$ are yet present

\footnotetext{
${ }^{1}$ In this connection the report of the German corvette captain, von Werner, of Dec. 19, 1878, from the South Sea station, the harbor, Makada of the Duke of York, is highly interesting:-
} 
and vaguely apprehended, receive protection unconsciously (and one may say instinctively) through the forms and standards governing the affairs of private persons.

The infringement of interests, such as in the present age are treated absolutely, in the law, as interests of the community, were, in earlier stages of civilization, sanctioned by the same means, and in the same manner, as purely private interests. Thus taxation, which in the modern view, belongs solely to the fiscal sovereignty of the state, was provided for in the German Middle Ages to a large extent by a contractually derived legal arrangement, according to analogy of private law. The relations of feudal dependents received little regulation by means of public law.

Instead of legal interference by public law for the protection of public interests, there was allowed (as also in the Roman law) a system of private actions by private persons. Accordingly, instead of the legal personality of the community, the legal personality of the head of the state was regarded as the private legal owner of interests to be protected by public law. The community in private law was not considered as a person, but, instead, the head of the state.

On the other hand, however, it is to be observed, in lower orders of civilization, ${ }^{1}$ that private law is pushed

\footnotetext{
"There was no other way to preserve German influence in this region than the purchase of a harbor; as in the present low condition of civilization of this racc, the conclusion of an (international) agreement was out of the question. Their intelligence is not yet equal to such an agreement." (See the official memorial which was presented to the German Reichstag with the Samoan agreement of Jan. 29, 1879: No. 239, p. 153 of the proceedings of the Reichstag).

${ }^{1}$ Cf. the above memorial (p. 157), according to which there did not exist among the South Sea Islanders any secure personal ownership, but only family, tribal or chieftain ownership. See sec. 20 , infra, with regard to the development of private ownership. With reference to community or chieftain ownership among these people ("tabu" and "blul") and community labor ("makesang") see also Karl Semper, Die Palcoinseln, pp. 49, 72, 73. 120.
} 
in to the background by state law in the case of interests which we now recognize and protect as interests of individuals, and which by such civilizations are given a very extensive protection as interests of the community.

From the standpoint of the modern conception of law the following propositions must be advanced:-

1. The actual delimitation of private law from public law, a distinction which was already made by the Romans, ${ }^{1}$ is nothing other than an answer to the decisive question, Whose interest is to be protected? In the interest of whom shall an actual relation of fact be elevated to a legal relation? The answer to this question lies with legislation. It must be regarded as the greatest function of legislation to determine what advantages shall be legal advantages of the community. The state in this activity, in which it creates a legislative public law (in the narrow sense), is legally independent. It may therefore mark out the limits of public and private interests as it wills. In like manner, the state may also establish a common domain for individuals and the community, in which interests of the community and of individuals are coincidently invested with the protection of public and private law. ${ }^{2}$

2. Rights are created by public as well as by private law. For example, the state by virtue of established legal standards governing military service has a right to demand the registration and conscription of persons capable of such service. Official rights and official powers which belong to public officers (or to public societies), or to military commanders, are, in their essence, rights of the community. They are based only on social interests, and accordingly are public rights.

\footnotetext{
1 Ulpian, Dig. 1, 1, 1, 2; also Julian, Dig. 1, 1, 4.

${ }^{2}$ As in the case of ownership, for the protection of which there may be public punishment, as in larceny, and action for a private remedy,-restitution or compensation. The interest in human life and in human heaith is another example.
} 
These rights of public servants may also be considered as transferred on the part of the state. Or it may also lie in the public interest to regard the possession of official authority as vested rights of such public officers. ${ }^{1}$

3. The community, as well as individual private persons, may coincidently have an interest as to any relation of fact. It is also conceivable that such an interest may exist concurrently in the international community; in the dominant governing entity, whether of one or more states; in a community within the state; and in individual private persons. In such case the relation is protected by international, state and private standards. $^{2}$ The protection of the same interest by one standard does not exclude the others. Public interest may particularly require the fulfillment of a private agreement according to its terms. ${ }^{3}$

4. Ethnological, historical, climatic and other internal and external influences, which are of significance in legal evolution, operate with much greater difference of consequence on the form of public than of private law. It is true that a greater diversity is possible in the private law of a state than in its public law, inasmuch as the public law of a state must be unified in its structure. Yet there is a greater variation in the interests guaranteed by public law among states of the same level of civilization than in their private laws. Therefore, the reception of foreign institutions of private law is more easily possible than the reception of foreign institutions of

'Cf. Gareis, Allg. Staatsrecht, in Marquardsen's Handbuch d. off. Rechts, Bd. I, pp. 13, 14.

${ }^{2}$ E.g., the robbery and murder of a married soldier lying wounded on a battlefield by battlefield ghouls may possibly include an infringement of all the standards mentioned.

${ }^{3}$ Cf. Str.G.B., sec. 329 : "Whoever agrees with the public authorities for the delivery of provisions for the use of the army or the navy in time of war, or for necessities for use in a time of distress, and who shall intentionally fail to make delivery at the stipulated time, or in the stipulated manner. shall be imprisoned not less than six months, and nay also be deprived of his civil status."-Gareis, Reichsgesetze. No. 143-146. 
public law; and the reception of the latter requires the exercise of the greatest circumspection. ${ }^{1}$

5 . The supremacy of public law in the protection of established rights of the community demands that private interests shall, under definite conditions, give way in cases of conflict to the public interest. It is also a consequence of the sovereignty of public law, comparable to the force of the idea of law itself, that the dominant social entity shall assume the nature of a private person,-in this sense, called the fiscus,--and, in this character, be regarded and treated like a civil person.

1 With reference to the relation between public and private law see Gareis, Allg. Staatsrecht, in Marquardsen's Handbuch d. off. Rechts, Bd. I, sec. 3, pp. $7,11-15$, and the literature in the notes. 


\section{(A) CIVIL OR PRIVATE LAW}

\section{SECTION 15}

\section{ELEMENTS OF CIVIL OR PRIVATE LAW}

It is the function of private law to protect the interests of private persons. These interests consist of relations to objects, and the protection of these relations against deprivation, infringement and interference. Such relations, however, arise or exist under the influence of legal order as legally regulated relations based on definite facts, or so-called juristic facts. The law attaches its protection to these facts. Rights, therefore, spring from the creation, extinction or alteration of such facts.

The law recognizes private interests, not alone for the sake of the individual, but also for the sake of society. Its viewpoint is social as well as individual. Only those private interests are protected, by the authority of the community, which are conformable to the general welfare. Even in private law, where legal order first of all provides for individual interests, it must also strive for the common good. This is the social object of private law. ${ }^{1}$

Out of the foregoing objects arise the following four elements of private law: (1) a legal subject, (2) a legal object, (3) a juristic fact, and (4) legal protection.

I. Legal subjects ${ }^{2}$ are the owners of their legally protected interests. A person is any entity which may be the holder or owner of such interests. Legal order

${ }^{1}$ Gierke, Die soziale A ufgabe des Privatrechts (Berlin. Julius Springer, 1889), particularly p. 6; cf. Ihering, Zureck im Recht I, pp. 64, 82, 99: "The truth of the proposition-every person exists for the world, and the world exists for every one-is found in society."

${ }^{2}$ Salkowski, Inst., secs. 42, 79; Sohm, Inst., secs. 20-25. 
makes provision accordingly as to what entities have this capacity, which is called capacity for rights, and which is synonymous with personality. Capacity for rights is distinguishable from capacity for acts. The latter is a legally recognized capability of exercising the will in juristic acts. ${ }^{1}$

The law may distinguish various kinds of capacity,for rights, as well as capacity for acts; differing according to age, ${ }^{2}$ sex, family status, rank, social position, ${ }^{3}$ residence, ${ }^{4}$ etc.

The distinction based on social position depends always on the political history of the people and has an internal connection with previous facts concerning the state. This is particularly true of the distinctions arising out of birth; thus, the nobility (higher, middle and lower), the common people, mancipated persons, and the so-called half-free and slaves. All these divisions are frequently separated by impassable barriers. Caste is of this nature. Social position arising out of calling or vocation also generates capacities; thus, ordinary citizens (Bürger), tradespeople, soldiers, the clergy, artisans, peasants. All these persons are set apart in particular classes under special legal standards.

All persons are recognized as having capacity for rights, - even though, as pointed out, this capacity may be of different grades, - unless these persons are regarded

\footnotetext{
1 Thus, according to German law, children under the age of seven years are capable of rights but incapable of acts; the same is true of those persons who, on account of mental defects, are prevented from exercising a free determination of will. See B.G.B., secs. 6, 104, 105. Disposing capacity in the sense of B.G.B. is one of the subdivisions of capacity for acts. See Gareis, Kommentar zum B.G.B. I, note to sec. 104.

${ }^{2}$ B.G.B. distinguishes as follows: The period of minority up to the age of seven years; the period of minority in the strict sense, between the years of seven and twenty-one, in which there is limited disposing capacity (B.G.B., secs. 106-113); and the period of majority beginning with the completion of the twenty-first year. Minors of the age of eighteen may receive a declaration of majority (B.G.B., secs. 3-5).

${ }^{3}$ See sec. 18 , II, infra.

${ }^{4}$ B.G.B., secs. 7-11.
} 
as things or slaves in the lowest stages of bondage. These subjects of rights are called natural persons. ${ }^{1}$

There are, however, certain entities which are not human beings and which still have interests to which the law assigns legal protection. In other words, legal systems recognize the possession of rights which are not interests of individual persons but of other entities, or aggregates of persons or property.

It is not necessary that legal systems shall create such interests. The ideals and necessities of mankind recognize them before the law. Legal order under certain conditions invests such interests as are found to exist in fact with the protection necessary to transform such interests into legal advantages. The entities whose preterhuman interests are in such manner protected are called juristic (fictitious, artificial, or moral) persons in contradistinction to natural persons. Juristic persons are either aggregates of persons (universitates personarum ${ }^{2}$ ) or aggregates of things (universitates rerum)..$^{3}$

Private law recognizes the following classes of juristic persons:-

1. The state, or the governing social entity, in its private legal relations. In this aspect the dominant entity does not authoritatively represent its interests by virtue of its attribute of sovereignty. Its activity here is the same as that of any free citizen in the state in the satisfaction of private economic necessities. In this activity a state is called the fiscus, ${ }^{4}$ or treasury, in contradistinction to the activity in which the state

1 The first section of B.G.B. provides: "Capacity of persons for rights begins with the completion of birth." This excludes every spccies of corporal ownership and bondage. Capacity for rights continues until death, or until legal declaration of death (B.G.B., secs. 13-20).

2 B.G.B., secs. 21-79.

3 Foundations (Stiftungen) and institutions (B.G.B., secs. 80-89).

- B.G.B., secs. 89, 928, 1936, $1942,1966$. 
represents public interests of the community by sovereign law in the governing sense (res publica).

2. Public communities within the state, which represent public interests; thus, municipalities, "parishes, towns, provinces and similar communities. ${ }^{1}$

3. Aggregates of persons, such as associations (corporations) ${ }^{2}$ arising from joint concurrence or agreement, which have legal interests, in that the law gives them a legal position. According to the conditions of the legal recognition of their juristic personality, such corporations (collegia corpora) are: guilds and industrial fraternities, and those privileged aggregates of persons which are under state supervision (collegia sodalicia); for example, the Roman collegia funeraticia, and modern associations for accident, age and health insurance in the German Empire. These associations under state recognition have social objects as opposed to objects of the state or of individuals. ${ }^{3}$

4. Associations for profit (societates qucestuaria), which the law specially invests ${ }^{4}$ with the capacity for having rights; thus, share companies, ${ }^{5}$ registered associations, and mining companies, in the modern law.

5. Churches, churchly associations and institutions. ${ }^{\circ}$

${ }^{1}$ As to the historical importance of German real communities (Realgemeinden), mark associations, see infra, sec. 7, II.

2 B.G. B., secs. 21, 55-79.

${ }^{3}$ Of this class are associations for health insurance according to sec. 25 , imperial statute (June 15, 1883) (Gareis, Reichsgesetze 5, 147-8, 40); also fraternal associations for accident insurance according to sec. 23 , imperial statute (July 6, 1884) (Gareis, Reichsgesetze 6, 28-9, 40, 7, 14, 58, 60-1); and institutions for insurance according to sec. 68, Invalidenversicherungsgesetzes (July 13,1899) (Gareis, Reichsgesetze III, 12). It is one of the chief objects in the social aspect of the law (Sozialpolitik) to promote such associations having social ends with functions legislatively determined, and with definite rights fixed by statute.

${ }^{4}$ B.G.B., sec. 22 . Cf. Cosack, B.R., sec. 29.

${ }^{5}$ Share company (Aktiengesellschaft). Registered association (eingetragene Genossenschaft). Cf. below, sec. 23, III, 5.

' See Canon Law, below, sec. 57. 
6. Foundations, ${ }^{1}$ that is, complexes of property which are recognized by the law as holders of rights for the accomplishment of certain limited objects: pice causa, etc.

II. The object of an interest (which is the basis ${ }^{2}$ of all private legal relations) ${ }^{3}$ is always a relation of fact, of one or more physical or juristic persons, considered as legal subjects, with reference either to other persons or to things. The relation of a legal subject with reference to other persons forms either family law (sec. 25, infra) or the law of obligations (sec. 22 , infra). The relation of a legal subject with reference to things by virtue of which a thing is under the dominion of the person entitled, either in its entirety, or only in a particular way, makes the law of real relations (sec. 19 et seq.),the law of things.

Inasmuch as things (but not persons) may be subjected in whole, or in part, to the direct dominion of a subject, they are frequently called the objects of rights.

The conception, thing, ${ }^{4}$ includes-

1. Material things, as follows:-

(a) Movable things (res mobiles, Fahrhabe); thus, money, articles of commerce, goods, animals (res sese moventes), ${ }^{5}$ clothing, arms, provisions, etc.

1 B.G.B., secs. $80-88$.

2 With reference to this notion, see sec. 5, page 29, supra.

${ }^{3}$ Concerning the ideas, legal relation and condition, see notes 1 and 2 . under sec. 5 , p. 31 , supra.

'Salkowski, Inst., sec. 81; Sohm, Inst., secs. 45, 46. The kinds of things classified, B.G.B., secs. 90-103.

${ }^{5}$ Completely dependent persons-that is, slaves, where slavery exists as an institution, or has existed. are to be included among things. For illustration, in Germanic Volksrecht, servus and ancilla were coupled together with bos, equus, etc. Slavery had its origin in ancient times and in the Middle Ages in subjugation in war, and in conquest. Slavery of individual persons arose out of the relation of such persons to a people subjugated in war; out of slave birth, captivity, and servitude for debt. It is interesting to note that certain very ancient laws, in order to favor freedom of individual persons, in certain cases recognized a presumptio libertatis; thus, for example, the law of 
(b) Immovable things (res immobiles, Liegenschaften); thus, lands.

2. Immaterial things thus, corporal existence and freedom, reputation, authorship in works of literature and art, inventions, etc.

III. The relation which is the basis of an interest, forming a private legal relation, is established, conformably to legal order, by a definite fact. By this fact, legal relations acquire a characteristic legal protection, and the immanent interest is elevated to the plane of legal advantage. The impulse by which this is accomplished is called the juristic fact. Such a juristic faci is also required for the extinction or alteration of a legal relation or a legal advantage. ${ }^{1}$

Juristic facts include-

(a) Elemental occurrences in the course of nature. Such occurrences may be destructive, as in the case of a hail storm, or the death of persons or animals. They may be productive, as in the growth or ripening of fruits, or the birth of persons. Finally, they may be alterative, as in physical or chemical processes, or in a destructive or productive influence upon life and human interests through lapse of time. ${ }^{2}$

the Cretan city, Gortyn (about 450 B. C.). See A. Gmoll in the scientific supplement to the Programm des stâdt. Progymnasiums zu Striegau (1889, I, 14, p. 10).

1 The situation in which a young man, capable of marriage, stands to a young lady, and his interest in her, in her affection and fidelity, are protected only by the impulse of the juristic fact of an actionable betrothal or marriage. (Cf. below, sec. 26.) The interest which one may have in the complete use of a garden is first protected by the impulse, or juristic fact, of a conveyance, or recording of a title which makes the garden his property. ( $C f$. below, sec. 20.) The interest which one who suffers a physical injury has in damages for the expenses of his cure, lost time and smart-money, arises at the same instant that the injury is sustained. (Delict as a juristic fact, see sec. 24.) If the damage is fully satisfied by payment, then the payment (solutio) becomes the operative juristic fact of the extinction of the claim for damages. ( $C f$. below, sec. 22.)

${ }^{2} C f$. the legal institution of prescription B.G.B., secs. 194-225; usucaption, B.G.B., secs. 937-945; concerning time and dates, B.G.B., secs. 186-193. 
(b). Human acts, or the casually derived operation of the human will on the external world. These acts may be: (1) such as are in conformity with legal order, as governing external relations, and which accordingly are called lawful acts; or (2) such acts as are contrary to the rules of legal order, and which are called unlawful acts.

Juristic facts ${ }^{1}$ arising out of lawful acts are either unilateral dispositive acts, as in a voluntary transfer on the part of an owner of his ownership, or in the making of a will; or

Such acts are bilateral, in agreement, which is a concurrence of will of two or more private persons, whereby a change is to be effected in their rights, in accordance with legal order. The most important operation of agreement lies in the domain of the law of obligations (sec. 22). Yet there are agreements having a real operation (tradition, delivery) (sec. 20); and some lie in the domain of family law (sec. 31) and the law of inheritance (sec. 36).

Unlawful acts by virtue of positive law operate to create obligations to pay damages, ${ }^{2}$ penalties, or both, and of course operate also to extinguish or alter rights. ${ }^{3}$

IV. The fourth element of private law is the protection of the relation itself, ${ }^{4}$ or the protection of the interest. This protection extends so far as is possible with the means afforded to legal order,--command and prohibition,- - and so far as it desires to protect the individual having in view its social function.

This protection is afforded in a variety of ways.

1 Dispositive acts, see B.G.B., secs. 104-185.

2 B.G.B., secs. 823-853.

${ }^{3}$ The criminal act of setting fire to a house which completely destroys it extinguishes the object of ownership. The claim for damages therefore rests upon a different object than that of ownership. See note 2 , supra.

- Cf. Sohm, Inst., secs. 26, 33. 
1. In the abstract.

(a) Even in the ideal; that is, through the simple existence of legal standards. In this aspect, command and prohibition, as such, operate on morally governed and law-abiding men. It is sufficient for them to know what is commanded and what is prohibited, in order that their acts may conform to legal order.

(b) In a practical aspect, the simple existence of legal duties, the existence of courts, justice, the machinery of the law and public access to the courts with a possibility of judicial enforcement, are sufficient to deter many men from those acts which are prohibited, and to occasion those acts which are commanded by legal order.

2. In the concrete.

(a) Even to the extent of permissive acts of selfhelp, but only in cases of necessary defense (Notwehr), or necessity ${ }^{\mathbf{1}}$ arising from the existence of danger ( Notstand).

(b) Through precautionary judicial and extrajudicial measures of security: thus, Protestation ${ }^{2}$ (Verwahrungen) [declarations against consequences possible to be drawn from positive acts, or silence]; Reservation ${ }^{2}$ (Vorbehalte) [declarations limiting the ordinary effect of the abandonment or transfer of rights]; Kaution ${ }^{2}$ (Sicherheitsleistung ${ }^{3}$ ) [an act by which a future injury to a right may be either avoided, or by which, in the event of its infringement, restitution may be secured]; Realkaution ${ }^{2}$ [the giving of bail or pledge for security]; Verbalkaution ${ }^{2}$ [an agreement by. which the parties establish the compass of the right involved and the penalty for its violation]; Immission ${ }^{2}$ (Besitzeinweisung) [the act of the creditor taking possession of property of his debtor for

I B.G.B., secs. 227-231, 859 .

[German, legal terminology.]

3 B.G. B., secs. 232-240.

$C \dot{f}$. suretyship (Bürgschaft), sec. 23. infra. 
security, corresponding to the missio in bona of Roman law ], etc.

(c) Procedural assertion of rights threatened or infringed, by means of action including either complaint or plea. (See below sec. 50, Civil Procedure.) 


\section{SECTION 16}

\section{SYSTEM OF CIVIL LAW AND ITS DEVELOPMENT IN GERMANY}

\section{(a) The System}

The systematic classification of private legal standards must be based on those interests which subjects of rights have or may have by virtue of their existence, and their real or artificial will. These interests exist with referto things, or the attitude of persons. Otherwise expressed, the object of these interests is-

(a) A situation with reference to a thing; or

(b) A definite attitude of a person. ${ }^{1}$

Accordingly there arises a twofold legal division:-

(a) Legal standards by which a situation of persons to things is maintained; and

(b) Legal standards by which a situation of persons with reference to other persons, or an interest in the attitude or conduct of other persons, is maintained.

The legal division corresponding to the rights involved is -

1 A double sense is to be borne in mind, as indicated above (sec. 5, notes 1 (p. 33), and 2 (p. 34)): whether the interest is that of an unrestrained determination of the will, or whether the interest is in an object. It is to be further remarked that an interest in the conduct of a person may be directed immediately toward a thing. The vendee of a horse, to whom delivery has not yet been made, has, of course, an interest in the horse; but his situation with reference to a particular horse, or a horse in general, is not such as legal order will protect solely on the ground of a contract of sale. It is accordingly possible to distinguish between an economic interest, and a juristic interest or a legally protected interest.

The existence of an economic interest is recognized by law to the extent that a creditor is obliged to accept the performance of an obligation through a third person who is not his debtor. (See B.G.B., sec. 267, and cf. Windscheid, Pand., sec. 342, 4, and literature there noted.) But the legally interesting, the actionable, and above all the protected fact is still the interest of the creditor in the conduct (performance, payment, etc.) of the debtor. 
(a) Rights with reference to things; and

(b) Rights with reference to persons.

Inasmuch, however, as things consist of material and immaterial property, the law of things falls into two groups:-

(a) The law of material things (secs. 19-21); and

(b) The law of immaterial things (secs. 17-18).

In like manner, interests in the attitude of persons present a further division.

Such interests may arise from natural (physiological) and ethical relations inherent in kindred life and from other relations growing out of such association. In other words, these interests may arise from the naturoethical nature of the family, or they may spring from voluntary acts of persons having a free determination of will. Obligatory interests may arise from duties voluntarily assumed and requiring a definite attitude in accordance with legal order, as when a person obliges himself to certain conduct by agreement. Such duties may also spring from acts in contravention of legal order,- - delicts, - and oblige a person to a definite attitude; such as an obligation to pay damages.

The law of persons accordingly severs into-

(a) Family law (secs. 25-29); and

(b) The law of obligations (secs. 22-24).

The law of immaterial things, which includes the right of freedom from restraint, freedom from injury, the right of reputation, and the right to intellectual creation, may also be considered as the law of personality. This division relates to rights peculiar to one's own person (Rechte an der eigenen Person, oder Persönlichkeitsrechte') (secs. 17, 18).

1 [To avoid possible confusion, it should be stated that these rights form simply one of the classes of the major division, rights in rem, as opposed to 
The foregoing concludes the strict logical arrangement of the law. Didactic and practical considerations of expediency require a f.rther distinction. Its basis is that certain events at one and the same time may essentially involve materialand immaterial things, the law of obligations, and family law, and may affect the whole existence of persons in their economic relations. These events operate as juristic facts. They accordingly might, like all other juristic facts, remain unnoticed in a systematic arrangement of the law, except that in such case their position would necessitate separate prominence in every department of law. Such a plan would be extremely cumbersome, and would lose in that comprehensiveness and clearness which necessarily follow from a sameness of starting point which is systematically adhered to.

Events of such extensive influence as to involve the four groups of the law which have been classified are-

The death of a physical person; and

The creation, alteration or extinction of a family relation, which while susceptible of consideration as an object of interests, may be regarded at the same time as a dispositive juristic fact.

In consequence of the practical necessity of classifying such events, two groups of legal rules arise, which may be combined under the expression, "mixed law of persons and things." The first of these groups is based on the event of death and produces the law of inheritance. The second governs the relation of pure family

rights in personam. Rights in rem avail against the whole world, while rights in personam attach only as against definite persons.

There is another leading division of rignts, $i . e .$, propriefary and personal. Proprietary rights have an economic basis, while personal rights have only a juridical basis.

Rights peculiar to the person in the sense here are one of the divisions of the law of things. See appendix. See also Salmond, Jurisprudence (2d ed., 1907), sec. 82; and Schuster, Principles of German Civil Law (1907), p. 67.] 
law to the law of things and obligations, and is called the law of family property.

Private law, therefore, is classified into the following six divisions:-

I. The law of personality;

II. The law of material things;

III. The law of obligations;

IV. Pure family law;

V. The law of family property; and

VI. The law of inheritance.

(b) The Historical Evolution of German Civil Law.

The formative rules of the divisions of the legal system, as above developed, did not emerge in a symmetrical evolution among the German people. The Germans, after the collapse of the empire of Charlemagne and until very recent times, lacked political unity and a systematically operative and unified legislation.

Although certain ancient and basic Germanic principles were to be found in the legal groundwork of the various German races, yet their law differed widely in detail. These differences became intensified as they drew apart politically. At the end of the Middle Ages, every territory and province, and, in fact, every city of any consequence, had its own code, Landrecht or Stadtrecht.

This manifold diversity and multiplicity of particulars was overcome by the Roman law, which became familiar to the German people in the form of the legislation of the Byzantine emperor, Justinian (528-532); partly by means of the Roman church; and partly through the universities, first in Italy, and later in Germany. This legislation presented the agreeable picture of an imposing world-law; and at least from the fifteenth century onward the corpus juris of Justinian was employed by 
the cultured as a. matter of course in the administration of justice, as so-called auxiliary common-law.

By the reception of Roman law, Germany attained a definite legal unity. It did not militate against this that the indigenous Landrechte and Stadtrechte (particular law) first were applied, as a rule, in matters of private law, inasmuch as the foreign Roman law was intended to occupy only a subsidiary or auxiliary position to the local law, for the purpose of filling up its vacant spaces.

In fact, however, many principles of German law were crowded into the background, and many German legal institutions were entirely displaced in favor of the Byzantine law. This fact is to be deplored. The situation gradually impressed itself on the minds of jurists and statesmen of the seventeenth century, so that, notwithstanding the deserved applause of the elegant and symmetrical "juristic art of the Romans," the abolition of Roman law in Germany came to be considered.

This revolt from Roman law first occurred in the northeast corner of the present German Empire. In 1620 the Landrecht of Prussia abolished the validity of Roman law, refusing to recognize any subsidiary law. This position, however, was maintained only for a century, as the Prussian Landrecht of 1721 again established the subsidiary currency of Roman law. At the same time, however, there prevailed in other places the desire for emancipation from the Roman law. King Frederick William I of Prussia entertained this feeling, but the problem of abolition first was put into execution under Frederick the Great, and completed under Frederick William II. "In place of the former Roman, common Saxon and other foreign laws," a "general Landrecht for the Prussian states" was proclaimed, and on June 1, 1794, attained legislative operation to the 
complete exclusion of the Roman law in the kingdom of Prussia. Legal unity was not attained by this legislation, as codified provincial law still had a primary validity. An exclusive provincial law also remained in force in various parts of the Prussian state.

The conditions transmitted from the Middle Ages persisted for the remainder of Germany. Numerous varieties of Stadtrecht and Landrecht of obscure origins and of small territorial authority remained, with Roman law as subsidiary law. Roman law was excluded only in the Rhine provinces, where the foreign authority of the Code Napoléon of 1804 became current; and in the kingdom of Saxony, where in 1863 a special civil code was established.

Prior to the operation of the German Civil Code, on Jan. 1, 1900, four different and important legal domains within the German Empire were to be distinguished, within which domains there were yet prominent various smaller legal circles or domains, as follows:-

1. That domain where Roman law was subsidiary or common law: The kingdom of Bavaria (with the exception of the Rhine Palatinate, where the French law was current, the former principalities Ansbach and Bayreuth, where the Prussian Landrecht prevailed, and various formerly Austrian villages, where the Austrian civil code of July 7,1810 (effective since Jan. 1, 1812, in accordance with the proclamation of June 1, 1811), prevailed to the exclusion of Roman law); the kingdom of Württemberg; the grand duchies Hesse (except RhineHesse, where the French law prevailed), MecklenburgSchwerin, Saxe-Weimar (except those parts previously raised to the rank of principalities), Mecklenburg-Strelitz and Oldenburg (except Birkenfeld); the Saxon duchies, and the duchies Braunschweig and Anhalt; the seven principalities, and the three free cities; the newer Prus- 
sian domain in which the Landrecht was not established the provinces Hanover (with the exception of Aurich, Lingen and Duderstadt, where the Prussian Landrecht prevailed), Schleswig-Holstein and Hesse-Nassau; the governmental districts Stralsund and Sigmaringen; and Wetzlar, Neuwied and Altenkirchen.

In this territory, which in the year 1896 was inhabited by about sixteen and one-half million persons, there prevailed as of the highest importance the special or local law of the particular province or city; as, for example, the Landrechte of Bavaria (1756), Württemberg (1610), Mainz (1755), Bamberg (1769); the upper Palatinate (1657) and the Solmser Landrecht (1751); the Stadtrechte of Hamburg, Bremen, Lübeck, Frankfort on the Main, Nürnberg, and others.

2. The legal domain of the general Prussian Landrecht of 1794: The Prussian provinces, East Prussia, West Prussia, Posen, Silesia, Brandenburg, Pomerania (except the governmental district Stralsund), Saxony and Westphalia; the governmental district Aurich, Lingen and Duderstadt, and the eastern portion of the Rhine Province in Hanover; the principalities Ansbach and Bayreuth, now belonging to Bavaria; and the domains previously created into principalities and now consolidated with the grand duchy Saxe-Weimar.

This territory embraced a then population of more than twenty-one million persons, but it was without full legal unity, as there prevailed alongside of the Prussian Landrecht particular laws of different territorial authority; as, for example, the East Prussian provincial law of 1801, that of West Prussia of 1844, etc.

3. The domain of the French law, which embraced the western portion of the Prussian Rhine Province, the Bavarian Rhine Palatinate, Rhine-Hesse, the imperial 
province Alsace-Lorraine, and the grand duchy Baden, where a translation of the Code Civil of 1804 prevailed as the Baden Landrecht. This territory included a then population of eight and one-half million persons, of which $1,700,000$ belonged to Baden.

4. The domain of the Saxon civil code of 1863 , which embraced, exclusive of the kingdom of Saxony, about three and one-half million inhabitants.

It is to be further noted, as already indicated, that in the Bavarian governmental district Upper Palatinate, and in the market Redwitz, belonging to the Bavarian governmental district Upper Franconia, the general code of Austria of 1811 prevailed; and that in that part of the province Schleswig-Holstein which formerly was a part of Jutland the Danish law in the code of 1683 of Christian V prevailed.

This very undesirable legal situation ended with the last day of the year 1899, since on Jan. 1, 1900, a unified civil law became operative for the whole German Empire, by which the Roman law, the French law and all Landrechte, relating to civil matters, were deprived of validity.

The consummation of such a legislative work was thought to be hazardous both at the time of the establishment of the North German Federation and at the time of extension of this federation into the German Empire in the year 1871. At that time it was thought to be sufficient that, of the whole private law, -apart from the law of patents of invention and so-called ownership of immaterial property,-only the law of obligations, alongside of commercial law, and the law of bills of exchange, should be reduced to uniform legislation. However, the expediency of imperial legislation in the whole domain of civil law attained expression in the imperial statute of Dec. 20, 1873. 
A commission was appointed of eleven jurists who co-operated in the draft of a civil code. The members of this commission labored for seven years in the drafting of the separate parts of the code (September, 1874, to October, 1881), and six years in common deliberation on the work. At the end of December, 1887, the completed draft of a civil code for the German Empire was presented to Imperial Chancellor Count Bismarck by the president of the commission, Privy-Councillor Pape, and was transmitted by the chancellor to the Bundesrat. After the publication of this work, with supplementary "motives" explanatory of the labor, the critics began an exhaustive examination of the draft, which prepared the way for a revision.

A second commission, authorized by the Bundesrat, followed, composed of practical men, in part members of the first commission; the chairman of which was the state secretary of justice. In 428 sessions, from April, 1891 , to December, 1895 , this commission completed its draft of the code; thereupon the Bundesrat adopted the draft as a legislative proposal, and the imperial chancellor, Prince Hohenlohe, on Jan. 17, 1896, transmitted it to the Reichstag for its constitutional concurrence.

The Reichstag, after a first reading on the third, fourth, fifth and sixth days of January, 1896, committed the draft of the code to a commission of twenty-one members for consideration and a report thereon. This commission ended its labors by the eleventh day of June of the same year. A second reading was had based on the report of the commission, in the Reichstag, in plenum, from the 19 th to the 27 th of June; and a third reading on June 30 and July 1 . On July 1 the civil code bill was passed by the Reichstag, and on July 14 the bill received the concurrence of the Bundesrat. The imperial sanction was given on August 18, whereupon publication 
followed in the imperial legislative bulletin on Aug. 24, 1896. (R.G.Bl. (1896), No. 21, pp. 195-650.)

Accordingly since Jan. 1, 1900, there has prevailed, owing to these efforts, a constitutionally operative and unified law for the civil affairs of the German people.

The civil code of the German Empire is divided into five books. The first book deals with, and is entitled, "General Principles"; it embraces seven sections differing widely in nature and treatment, as follows:-

I, Persons (1-89); II, Things (90-103); III, Acts in the Law ${ }^{1}$ (104-185); IV, Periods of Time and Dates (186-

1 [Rechtsgeschafte. This term is frequently translated "juristic acts"; but in this an ambiguity is encountered, since a juristic act includes not only acts of persons (acts in the law), but also acts so called or the operative effects of the law (acts of the law). This section of the code deals only with the first sense of juristic acts.

The following outline summarizing the ideas developed in this section and other ideas not touched upon, may be found useful:-
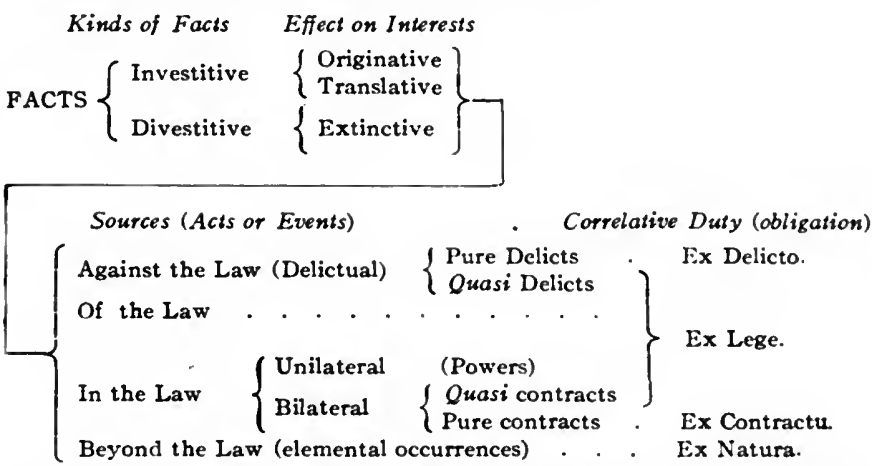

It is to be explained that bilateral acts in the law are not exhausted by the enumeration of contracts. Grants, assignments and releases are also included.

Objection may be made to the use of the term "powers" as coextensive with unilateral acts in the law. This term is more frequently employed to designate divestitive acts. It is submitted, however, that it serves a useful function in juristic terminology in the broader application to include also investitive acts (for example, wills), inasmuch as there is no compact term to indicate investitive unilateral facts.

This table is based on Benthamic terminology, in its primary divisions. The list of sources adopts the language of Pollock, with some additions that appear to be necessary for logical completion of the table.l 
193); V, Prescription (194-225); VI, Exercise of Rights (226-231); VII, Security (232-240). The second book (241-853) is entitled "Law of Obligations"; the third book (854-1296) deals with the "Law of Things"; the fourth deals with "Family Law"; and the fifth with the "Law of Inheritance."

There was annexed to the code an introductory statute which provided that the code should become effective on Jan. 1, 1900. It contains a variety of transitional legislation, as well as fundamental rules governing the relation of the civil code to imperial and state statutes, the latter of which, so far as relating to private law, are nullified in their totality to the extent that the contrary is not expressly provided for in the civil code itself or the introductory statute (art. 55-152, 218).

Concurrently with the civil code, there became operative a number of other codified acts. The most important was the new commercial code of May 10, 1897. Other statutes made changes in civil procedure, bankruptcy and trade regulations. 


\title{
THE SYSTEM OF CIVIL LAW IN DETAIL
}

\author{
CHAPTER I \\ THE LAW OF PERSONALITY ${ }^{1}$ \\ SECTION 17
}

THE LAW OF PERSONALITY IN GENERAL

The materials of what is called the law of personality are the interests which a legal subject has in his existence as a person and in his activity as such, and the recognition by law of this existence and activity. The legal advantage, to which protection is assigned, is an unimpeded activity and expression of personal individuality. Positive law in every age and of every people must give recognition to this legal advantage. This recognition is, however, accomplished in different degrees. The clearest recognition of such interests appears in the protection which modern law seeks to afford against murder, other illegal killing, injury of the. person and against deprivation of liberty. But this recognition is displayed in a great variety of other ways, as follows:-

1. Measures for the maintenance, ascertainment or establishment of rights of personality; as, for example,

1 On the theory of the law of personality or individuality see Gareis, in Busch Archiv f. H. H.W.R., Bd. 35, p. 185 (1877); Gareis, Kommentar des Patentgesetzes of May 25, 1877 (Berlin, Carl Heymann, 1877); and Gareis, Grundriss zu Vorlesungen über deutsches bürgerliches Recht (Giessen, Emil Roth, 1877), secs. 40-46. See also O. Gierke, Z. F. H.R., Bd. 29, p. 270 : J. Kohler, Jahrb. f. Dogmatik, Bd. 18, pp. 129, 251: J. Kohler, Recht d. Markenschutzes, p. i; O. Gierke, D. Privatrecht, secs. 81-99. 
by establishment of a register of civil position, of nonmercantile partnerships, corporations, unincorporated societies and firms, etc.

2. Legal measures which are intended to counteract infringement of these rights or even the menace of these rights; thus, the threat of punishment, the imposition of damages, and the tolerance of self-help and self-defense in their protection; and

3. Legal provisions by which these rights may be in part at least commercially controlled, transferred, limited, and transmitted by inheritance.

Rights peculiar to the person may be divided into two groups, the first of which involves a definite condition or situation of the person, such as bodily integrity and reputation. The other includes rights of authorship, such as rights of literary, art or technical invention. In both of these groups of rights, the protection of the law is directed against the whole world, as in real rights (dingliche Rechte). They do not require the existence, from the beginning, of a definite person obliged, or such a person ascertainable, as in the case of obligations.

Rights of personality are related to property without depending exclusively on proprietary ends, and without being protected essentially for the sake of property. There is a personal and more intimate connection between the person entitled and the legal advantage secured by these rights than between a legal subject and material property. Yet the furtherance of a pure right of personality may become the source of proprietary rights. Infringement of a pure individual right may lead to a duty of answering with material property, and may become in this sense proprietary.

The proprietary operation of an author's right is disclosed in the sale of his printed work. A proprietary operation is also found in cases where corporal injuries 
lead to the payment of smart-money, and where violations of rights of personality involve damages. In these cases property is not involved, but only ideal things are concerned. ${ }^{\prime}$

${ }^{1}$ See B.G.B., secs. 847,1300 


\section{SECTION 18}

\section{RIGHTS OF PERSONALITY. IN DETAIL}

I. The rights of physical integrity, physical freedom and physical activity spring directly from a recognition of personality or a recognition of capacity for rights. ${ }^{1}$ They attach to free persons without formal premises and without conditions. ${ }^{2}$ Practical limitations arise in these rights in parental power ${ }^{3}$ and in contractual obligations. Yet these limitations are never permitted to proceed so far that a person may be enslaved or placed in a condition similar to slavery. ${ }^{4}$

Within these limits, there may be limitations on freedom of activity by legal prohibitions; as in boycott laws; by agreements requiring positive performances of contracts for labor or services ${ }^{5}$ or by agreements requiring negative performances as in contracts relating to competition in business. ${ }^{6}$ This limitation on personal activity receives an industrial recognition in police legislation affecting freedom of trade, ${ }^{7}$ and political recognition in legislation relating to freedom of domicile ${ }^{8}$ and emigration. ${ }^{9}$

${ }^{1}$ Cf. B.G.B., sec. 1.

2 See Kohler, Einf., pp. 28, 29.

3 B.G.B., secs. $1631,1617$.

${ }^{4} C f$. concerning slavery, infra, sec. 15 , note 5 (p. 106).

${ }^{5}$ See below, sec. 23 , No. 13 et seq.

${ }^{6}$ Cf. H.G.B., secs. 60,74 .

7 Trade-regulation statute (G.E.A. III, 1 (183-190-); and also see Biermann, Privatrecht und Polizei in Preussen, cap. 1 (Berlin, 1897).

${ }^{8}$ Freedom-of-domicile statutes of Nov. 1, 1867, and Aug. 16, 1896 (G.E.A. I, $2,2 a(17)$ ).

${ }^{9} C f$. the imperial statutes, June 1,1870 , and Aug. 16, 1896, regarding the acquisition and loss of federal and state citizenship (G.E.A. I, 1, 1a (16)), and the statute relating to emigration (G.E.A. II, 26 (213)). 
Penal law protects to a wide extent corporal integrity, freedom and activity. ${ }^{1}$ In cases of necessity, ${ }^{2}$ illegal infringement of these immaterial objects may be prevented by self-defense (Notwehr); and in all cases their infringement. involves the obligation of paying damages $^{3}$ or making compensation.

As a development, and in part in consequence, of the first right of personality (the right in one's own person) there arises the right in one's own body ${ }^{5}$ and in one's own likeness. ${ }^{-}$The right in the human body has special importance where the question arises whether a surgical operation shall be performed, and where the surgeon's liability to respond in damages ${ }^{7}$ is involved. This right also extends beyond human life as in legal relations with reference to human corpses. ${ }^{8}$

II. The right in a name, ${ }^{8}$ in commercial names (such

${ }^{1}$ German Criminal Code, secs. 211-222, crimes and misdemeanors against life; secs. 223-233, injuries to the person; secs. 234-241, offenses against personal freedom; secs. 201-210, dueling; secs. 174-182, and also special crimes and misdemeanors against morals (G.E.A. V., 3 (143-146)). See also the statute against slavery and slave trade of July 28,1895 (G.E.A. V, 5 (199)).

${ }^{2}$ Self-defense, B.G.B., secs. 227, 859; Criminal Code, secs. 53, 54, 145, 329,360 , No. 8 .

${ }^{3}$ B.G. B., secs. 823, 847, 1300; see infra, sec. 24, obligations of delict.

t Criminal Code, sec. 231. With reference to the transferability of such claims, see Gareis, Grundriss, sec. 41.

${ }^{3}$ Gareis, "Das Recht ain menschlichen Körper" in the festival publication of the juristic faculty of Köningsberg for J. Th. Schirmer, Konnigsberg, I. Pr. (1900), p. 61.

- Keyssner, Das Recht am eigenen Bilde (Berlin, 1896), also the same writer in D.J.Z., 486 (1898).

${ }^{7}$ Endemann, Die Rechtswirkungen der Ablehnung einer Operation, etc. (Berlin, 1893), Einführung in das Studium d. B.G.B., sec. 131: Gareis, op. cit. (note 5), pp. 63, 98; Fr. v. Liszt, in der Z.S. f. ärztl. Fortbildung (Jena, 1904), Nos. 6, 7, 8.

${ }^{8}$ Gareis, op. cit. (note 5), pp. 91, 92, 94-05, and the same writer in $d$. Blatter f. R. Anw. (1905).

${ }^{9}$ Right of action on account of an unauthorized use of a name, sce B.G.B., sec. 12; the wife takes the name of the husband, B.G.B., sec. 1355; concerning the name of a divorced woman, B.G.B., Sec. 1577, the name of chil- 
as firm names), ${ }^{1}$ and the right to reputation. ${ }^{2}$ The infringement of these rights is followed by an obligation to make reparation in money and, to a certain extent also, by punishment. .

III. The right of original, or individual discovery or creation. When something is created of an original nature which may be employed in the arts or the sciences, a right is recognized therein, and is to a certain degree protected against unauthorized imitation, as in the following cases:-

1. The protection of marks of goods arising out of a definite manner of production and industrial use,- the protection of trade-marks. These marks have a historical connection with house-marks or hand-tokens, and are used like names for individualizing things and making prominent their connection with definite persons. In the Middle Ages, hand-workers (such as armor-makers, and stone-masons) employed hand-marks; and in early times tradesmen used commercial marks to designate their goods. From this fact legal rules protecting such marks against misuse and imitation arose.

Such protection was afforded by the imperial statute of November 30,1874 , relating to trade-marks, ${ }^{3}$ which was displaced by the statute of May 12, 1894. Under the later statute (Sec. 1) not only every registered firm (as under the earlier statute) but every person is given the privilege of making registration in the trade-mark

dren, B.G.B., secs. $1616,1706,1719,1736,1758,1772$; the name of juristic persons, B.G.B., sec. 57, Einf. G. z. B.G.B., art. 133-166, H.G.B., sec. 19-20. For the literature of the law of names, see Gierke, Deutsch. Privatrecht,'sec. 83; Staudinger in Blätter f. R. Anw., Bd. 62, p. 161; Gareis, Grundriss, sec. 42; Gareis, Lehrbuch des Handelsrechts, sec. 16; Ramdohr, in Gruchot's Beiträgen, Bd. 43.

1 H.G.B., 2, 5, 8, 17-37.

${ }^{2}$ Criminal Code, secs. 185-200; B.G.B., secs. 823-826.

${ }^{3}$ G.E.A. II, $5 a$ (179). 
register of the imperial patent office at Berlin, of such of his goods as he desires to distinguish from the goods of others, and by which he may reserve to himself the exclusive use of his trade-mark. ${ }^{1}$

2. Originality in a trade, or business, may be protected $^{2}$ against unfair competition (concurrence déloyale) such as a misleading use of a business designation, ${ }^{3}$ or a betrayal of trade secrets, etc. ${ }^{4}$

The unfair competition act also combats untruthful "puffing" (Reklameschwindel), ${ }^{5}$ fraud in weights, ${ }^{8}$ and business slander ${ }^{7}$ (dénigrement).

3. The industrial law of previous centuries sought to protect individual activity by various (now for the greater part obsolete) special laws, such as the so-called Bannrechtc [which required the inhabitants of a certain locality or certain classes of such to provide certain necessities, and certain labors exclusively through privileged persons]; through commercial and industrial monopoly, etc. ${ }^{8}$

IV. Authors' rights:-

1. When the art of printing was discovered, publishers sought to protect themselves against imitation by privileges for particular books received from kings and princes. The regularity and continuance of this practice of granting privileged protection gave rise to a general rule that imitation was prohibited and the con-

1 In detail, the statute of May 12, 1894 provides for the effect of registration, secs. 12, 13; the obligation of paying damages for infringement of trademarks, secs. 14, 18, 21: punishment for willful infringement, secs. 14, 19, 22; prohibitions against illegal imitation of methods of packing goods (Ausstattung), sec. 15, and prohibitions against illegal designation of origin, sec. 16 .

2 Unfair Competition Act of May 27, 1896 (Gareis. Reichsgesetze, No. 201); see Gareis, Blätter j. R. Anw., Bd. 61, p. 321 .

${ }^{3}$ Unfair Competition Act, sec. 8.

"Ibid., secs. 9, 10.

s Ibid., secs. 1-4.

'Ibid., sec. 5; Gareis, Blätter f. R. Anw., Bd. 61, D. 370.

7 Ibid., secs 6, 7 .

Bannrechte, see Kraut-Frensdorff, Grundriss, sec. 118. 
ception of infringement of the right of publication. When the nature of this right is examined, it is found to be a part of, or a derivation of another right. Its nature is that of immaterial property, but it is found to be a right of the person, or a right of personality. ${ }^{1}$

2. The most important statutes in Germany which have given validity to authors' rights are: the Prussian statute of June 11, 1837; the Bavarian law of April 15, $1840 ;^{2}$ and the Saxon statutes of February 22, 1844, July 27, 1846 and July 30, 1855 . The Bund orders of November 9, 1837, April 22, 1841, June 19, 1845, and November 6, 1856, sought to protect authors' rights by a definite, mutual reciprocity on the part of the German states. $^{3}$

Unified German legislation in the domain of literary authorship was initiated by the statute of the North German Federation (later the imperial statute of June 11, 1870 (Bundesgesetzblatt, 1870, p. 339)) with reference to authors' rights in literary, pictorial, musical and dramatic works. This statute remained in force until January $1,1902 .^{4}$ On this date it was superseded by the imperial statute relating to authors' rights in works of literature and music (R.G.Bl., 1901, No. 27, p. 227). At the same time the statute relating to publishers' rights (R.G.Bl., 1901, No. 27, p. 217), came into force.

The L.U.G. of June 19,1901, is based theoretically on the proposition that an author's right is a personal right; which without the observance of any formality whatever belongs to the person entitled, governed by the simple matter of fact that he is the author of a

' This conception is attained by the philosopher, Immanuel Kant, who is in this respect followed by Renouard and Bluntschli. See also, note 1, p. 122 .

2 The criminal code of 1813 in Bavaria already recognized rights of the author as such. See Philipp Allfeld, Kommentar on the statute of June 19, 1901 , relating to authors' rights in works of literature and music, and concerning rights of publication (Munich, C. H. Beck, 1902), p. 2.

${ }^{3}$ Bluntschli, Deutsches Privatrecht, 3d ed. (Felix Dahn, 1864), sec. 46.

1 See Allfeld, op. cit., p. 4. 
meritorious (that is an original) literary work (L. U. G., secs. $2,5,6$ ), or one juridically so considered (L. U.G. 7, 29 abs. 2).

The formality of registration in the public record in charge of the municipal councilor at Leipzig; is necessary only for prolonging the period of protection of a work first appearing anonymously or pseudonymously. (L. U.G., secs. $7,31,56$ ).

It is the province of positive law to regulate the details of the content of the author's right (that is the actual scope of the author's power); the time or period of protection; and the extent or territorial domain of protection.

The content of an author's right is provided for in L.U.G. by recognition of a self-seeking interest of publicity or the privilege of publication $;^{1}$ also by recog. nition of an interest of literary use and adaptation; and finally by positive establishment of an exclusive power in the author: (1) of manifolding his work (L.U.G. $11(1), 15,25)$; (2) of commercial use (L.U.G. 11); (3) publication of its essential contents (L.U.G. $11(1,2))$; (4) public performance of dramatic and tone-works (L. U.G. 11, 1 (2)); (5) public recital prior to publication (L. U.G. $11(3), 26)$; and (6) the above enumerated exclusive powers (1-5) also extend according to L.U.G. $12,(1-4):(a)$ to translations into other languages, $(b)$ to re-translations into the original language, $(c)$ to dramatization and vice versa, and $(d)$ to abridgements and transpositions of tone-works. In all of these cases, however, a limit is drawn which will permit the free use of an auihor's works for bringing forth new works of creation. ${ }^{3}$

${ }^{1}$ L. U.G., secs. 16,17 (1 and 2), 18.

${ }^{2}$ L. U.G., secs. 19, 24, 25.

${ }^{3}$ L. U.G., sec. 13, art. 1. In tone-works, however, every use is prohibited in which a recognizable melody taken from the author's work is made the basis of a new work. 
With reference to the time limitation of an author's right, the normal period of protection according to L.U.G. (sec. 29) ends if thirty years have elapsed since the death of the author, and ten years since the first publication of his work. In anonymous or pseudonymous works, protection ends thirty years after publication unless in the meantime the true name of the author (L. U.G. $7(1,3)$ ) or the person entitled is entered in the registry at Leipzig. ${ }^{1}$

With regard to the territorial extent of an author's right, there are two decisive principles; namely, the absolute protection of citizens, and the protection of domestic priority. The law favors all German citizens in all their literary and tone-works (L.U.G. 54) without regard to the place of publication, and even without regard to whether a work has been published at all. The protection of German law extends to works of foreigners who publish works in the German Empire, if the work itself, or a translation, has not been published at an earlier day in a foreign country. By international agreement, the citizens of the contracting states and their assignees enjoy in all the states the same rights which are conceded to then in their own country. ${ }^{2}$

Authors' rights are designated ${ }^{3}$ as inheritable and transferable, but only in the sense of the right of the multiplication and circulation of the work; and not in the entire extent of the author's right; and finally not in the sense of the intensely personal conteni of the right. There is inherent a spiritual bond between the author and his work which continues even after a transfer

${ }^{1}$ L. U.G., secs. $31,56$.

${ }^{2}$ Berne convention of Sept. 9, 1886; the Paris supplementary proposal of May 4, 1896; the Germano-Austrio-Hungarian treaty of Dec. 30, 1899 and others. See Allfeld, op. cit., pp. 302, 396.

${ }^{3}$ L. U.G., sec. 8. 
of his rights. This is indicated by the continuing importance of the life of the author for duration of protection of the work; by the legally guaranteed unchangeability of the whole essential contents of the work (L.U.G. sec. 9); the rigid requirement of the author's consent to execution" (so far as his work may be the object of execution); and finally in that, after the transfer by the author to another of the right of multiplication and circulation of his work, there yet remains exclusively in him the right of translation, dramatization, or conversely, novelizing, and in tone-works the right of adaptation (L.U.G., sec. 14).

So far as authors' rights are transferable, the fundamental principles of civil law (for example B.G.B., 413, 493) and the law relating to publishers apply. In the latter case the contract of publication is of first importance. This contract is essentially a bilateral act in which the author (or author party ${ }^{2}$ ) obliges himself to deliver and sell to the publisher ${ }^{3}$ a work of literature or music for multiplication and circulation for a certain compensation; and in which the publisher obliges himself to multiply and circulate the work.

This agreement (the content of which, exhibits the features of a bilateral contract for work (B.G.B., secs. $631,613,651$ ), generates obligatory effects (B.G.B., 241, $305)$, which arise out of the duties above disclosed: namely, a transfer on one side, and multiplication and circulation of a work on the other. Whether a work is protected by L.U.G. or is an unprotected, or free work, is therefore material to the contract of publication; to the extent that in the first case the author is under obligation to the publisher, in case the right of

I L. U.G., sec. 10.

${ }^{3}$ Not necessarily the author; see V.G., sec. 49.

${ }^{3}$ Not necessarily a book-dealer; see motives of the draft of the V.G. (Reichstag publications, 1901, No. 97, p. 60). If a book-dealer (which is the rule) see H.G.B., sec. $1(1,2,8)$. 
publication is questioned to warrant the exclusive right of multiplication and circulation. The duty of providing the right of publication is also obligatory; but as soon as this duty is fulfilled, by providing the publisher with the legally protected work, there arises a species of real relation against third persons in the exclusive right of multiplication and circulation, which is called (in the special sense of V.G.) the publisher's right. ${ }^{1}$

Violations of authurs' rights may generate either civil claims for damages or penal actions. Civil action may be based on intentional or unintentional infringement; while penal action is based only on an intentional violation. The statute of limitations in claims for damages or punishment for infringement, is three years. ${ }^{2}$

3. Analogously to the protection given to authors of pure literary works, the imperial statute of June 11, 1870 , extended to the formative arts.

Full protection, however, was first afforded to these arts by the imperial statute of January 9, 1876, which followed in its provisions the statute governing the literary arts (June 11, 1870), and like that statute touched only the proprietary aspect of these rights.

In connection with the statute relating to the formative arts, the imperial statute of January 10, 1876, under certain conditions protected the proprietary use of photographs. The repressive features of this statute are similar to those against violation of other authors' rights; while the period of protection is more limited.

4. In the interest of the arts, the imperial statute of January 11, 1876, protected from imitation the rights of authors of artistic models and designs; such as those relating to carpets, tapestries, other printed, or woven

\footnotetext{
1 The business of publishing, see below, Law of Obligations, sec. 23 (No. 26): also. Gareis, Lehrb. d. H.R., 7th ed., sec. 59.

${ }^{2}$ Concerning infringement and its consequences, see $L . U . G$., secs. 36-53.
} 
goods, ceramics, wood-work, casting and other original artistic designs. Penal and civil repression against infringement are the same as in other statutes protecting authors' rights, and are based upon official registration of the model or design. The period of protection is different than in other authors' rights; and in certain cases in place of the actual author a fictitious author is protected.

V. Technicai rights of authors of new inventions which have an industrial value, whether in the domain of mechanics or in chemistry, or in both, may according to special statutes be protected against imitation for a certain period. This protection is afforded to the end that the inventor alone may, during this period, employ or allow the use of his invention. It is apparent that the advantage which is given to the inventor directly benefits society itself, in that it influences the spirit of discovery. In Germany after the protection of inventions was established as a matter of imperial concern and the hostile sentiment against patents was overcome, there came into force a patent statute which afforded equal protection against imitation for all kinds of industrially valuable inventions. This was the German patent statute of May 25, 1877. A distinction is to be noted between original inventions, on one hand, and useful models on the other.

1. Protection of inventions. ${ }^{1}$ The requisites are patentability ${ }^{2}$ and a formal declaration of the invention at the imperial patent-office at Berlin. The procedure of granting a patent is made up of the declaration,

\footnotetext{
${ }^{1}$ German Patent Act of April 7, 1891 with the imperial ordinance of Dec. 6, 1891 (Gareis, Reichsgesetze, Nos. 122, 123).

${ }^{2}$ Patents are granted upon new inventions which have an industrial value except in the following cases: (1) where the use of the invention opposes the law or good morals; and (2) inventions of food, articles of luxury, and medicine, as well as substances produced chemieally, so far as the invention does not relate to a definite process of manufacture.
} 
preliminary examination, publication and possibly demonstration of the invention, and lastly the execution of the patent. The longest duration of a patent is fifteen years.

The German law exercises a limited and qualified control over patent licenses and a restraint on the use of patents. ${ }^{1}$ It also recognizes a transferability and inheritability of rights in inventions and patents. It provides for the revocation of patents; and for a privileged use of inventions. ${ }^{2}$ It also provides civil remedies for infringement of patents and penalties for intentional infringement, as for frauds on patents. ${ }^{3}$

2. Protection of useful models: ${ }^{4}$ Models employed in labor, and implements of use, or parts of useful models so-called are protected against unauthorized use by registration in the imperial patent-office, if they exhibit new forms, new arrangement or adjustment. ${ }^{5}$ The procedure for granting this protection is simpler than in the case of patents of invention. The period of protection is three years, but upon payment of a larger fee the time may be extended three years.

German law provides for the establishment of a register for useful models in charge of the patent-office. It recognizes a transferability of useful models ${ }^{6}$; and provides penalties and damages for violations of the protection granted, similar to those of patent law. ${ }^{7}$

1 Patent Act. secs. 11, 28.

${ }^{2} I b$., sec. 5 .

${ }^{3} \mathrm{Ib}$., secs. $35-40$.

${ }^{4}$ Useful Models Act of June 1, 1891 (Gareis, Reichsgesetze, Nos. 122, 123).

${ }^{5} I b .$, sec. 1.

${ }^{6} I b .$, sec. 7 ; B.G. B., sec. 413 .

7 Useful Models Act, secs. 9-12. 


\section{CHAPTER II}

\section{THE LAW OF MATERIAL THINGS \\ ( $J$ ura in re,-real rights)}

\section{SECTION 19}

\section{THE LAW OF THINGS IN GENERAL}

I. It is characteristic of the law of things, that the protected interesi directly involves a thing. The interest lies in a situation directly referring to a thing, and in the immediate control of a thing for the purpose of use, consumption, possession, or transfer, as may appear necessary or desirable to the person entitled. This interest involves the proprietary aspect of things as property in the economic sense. Rights in things may be as numerous, or as few, as the diversity of the various legal institutions within the range of the law of things may admit. The duties correlative to these rights are the duties of every person. They are not the duties of particular persons (debtors) as in the law of obligations, but of all surrounding persons. They are duties of all persons who by possibility may come into contact with the thing or the owner of a real right, including all citizens and foreigners. A duty toward the owner of these rights, however, lies only in this:-

1. That the protected condition of the owner of the right is not to be disturbed;

1 Cf. Birkmeyer, Enz., 121-134 (Leonhard); pp. 312-335 (H. O. Lehmann) pp. 491-540 (Bernhóft), and the literature therein cited. 
2. That when necessary the duty corresponding to the right is to be recognized, or at any rate, the right is not to be opposed.

II. The interest of the owner of the right is either:-

1. In the legal control of a thing in the totality of its connections, which in this aspect is hypothetically protected. When a thing is protected in this widest extension of possible legal control, it is called the thing of the subject of the right, that is of the owner of the right. This complete legal control is called ownership, or

2 . The interest of the owner of the right may lie in the control of a thing only in particular aspects or situations, or even only in one aspect or situation. In this limited aspect it is free from interference; so that the thing in the totality of its connections or aspects, one or more connections excepted, is subject to the legal control of another person-the owner. A real right in a thing, the ownership of which belongs to another, is called jus in re aliena. These jura in re aliena are of various kinds. ${ }^{2}$ A right of ownership, apart from the varying significance which attaches to this right in different legal systems, can only be thought of as one right, the jus in re of the owner, or a jus in re propria. ${ }^{3}$

III. There are things which on account of their natural character, exclude all private legal control of private persons; as, for example, free air, the open sea and the flowing tide. Things of this class are called in the common (Roman) law, res extra commercium, or things beyond commerce.

${ }^{1} C f$. suits to establish rights, C.P.O., sec. 256: "Suit may be instituted to establish the existence or non-existence of a legal relation, or to establish the validity or the spuriousness of an instrument, if the plaintiff has a legal interest therein that the legal relation, or the genuineness or spuriousness of the instrument shall be forthwith determined by judicial decree."

${ }^{2}$ Sec. 21, infra.

${ }^{3}$ Sec. 20 , infra. 
IV. Differing from rights in things, but following, alongside, or ahead ${ }^{1}$ like the shadow, is possession (possessio). Possession is actual control or actual use of a thing, ${ }^{2}$ either in the totality of its possible aspectsin analogy to the case of ownership; or control in only particular kinds of use-as in jura in re aliena. ${ }^{3}$

Possession is not a right but a fact, yet it is,

(a) A legally protected fact, a legally protected condition; ${ }^{4}$

(b) It may be the consequences of rights. It may be a condition which the person entitled, for example, an owner, may demand; or it may be a situation of which a person entitled may require the transfer in conformity with an obligation; or

(c) It may be the occasion of rights. Under certain conditions possession may ripen into a right and the actual control become the legal control, as in usucaption ${ }^{5}$ (Ersitzung).

Legal systems are concerned with possession on account of these connections with rights, and establish standards for the acquisition, loss and protection of possession. ${ }^{6}$

Thus usucaption, where possession precedes the right.

2 In the older German law there is found a connection of fact with things, or of a fact connected with useful rights, which is similar to the fact of possession but which is yet legally different, and called Gewere, geweri, vestitura, or investitura. See Stobbe, Deutsches Privatrecht, sec. 72; Heusler, Institut. d. deutschen Rechts, Bd. I, p. 98, Bd. II, p. 20; H. O. Lehmann, in Birkmeyer's Enz., p. 312.

3 B.G.B., sec. 1029: protection of possession of a registered real servitude.

4 B.G.B., sec. 858: according to the civil code this condition is even inheritable (sec. 857); and in this respect it approaches the nature of a right.

${ }^{5}$ According to the civil code, a proprietary possessor (Eigenbesitzer) (sec. 872) of a movable thing may become the owner (sec. 937).

6 B.G.B., secs. 854-872. Cf. Dernburg, Pand., secs. 169-191; Sohm. Inst., secs. 53, 54; Cosack, Lehrb. d. b. R., secs. 185-194; Bernhôft, in Birkmejer's Enz., pp. 500-508. 


\section{SECTION 20}

\section{THE LAW OF OWNERSHIP}

( $J$ us in re propria, proprietas, dominium, ${ }^{1-R e c h t ~ a n ~ d e r ~}$ eigenen Sache)

I. The essence of ownership is legal control over a thing in the totality of its connections. This idea is as extensive as the possibility of use. Jus dominii embraces jus utendi, jus fruendi, jus possidendi, jus disponendi de substantia, jus alienandi, jus vindicandi, and every other thinkable right of conceivable use of a thing. ${ }^{2}$ The limits of this right are elastically variable, and subject to being narrowed down from or amplified up to full ownership. It is possible that other persons may have rights in a thing which limit the control of the ownerjura in re aliena. These rights of another may be so extensive that there may remain to the owner only an ultimate right of reversion, or jus recadentice. If these rights of another are, for any reason, lost, then the right of ownership by virtue of the power of control inherent in it, is automatically restored in its full extent.

Apart from jura in re aliena, the right of ownership, as of lands, is limited by equal rights of other owners, or by special legal restrictions. ${ }^{3}$

${ }^{1}$ Salkowski, Inst., sec. 87; Sohm, Inst., sec. 48.

[ $J$ us in re propria may be employed in a wider sense than the text to include any independent proprietary right whether in rem or in personam. The logical necessities of complete classification seem to require this wider application of this useful division of rights. Since neither the Roman nor Germanic law has any technical terminology to designate rights in intangible things such as patents, this division is limited by the Germans to independent proprietary rights in rem in material objects. See sec. 21. infra, note 1.]

2 [The term "right" is here used in a generic sense and includes "powers" and "liberties."]

With reference to the notion ownership and its limitations, see Gareis in Hartmann's Z. f. d. off. R., Bd. III, p. 137.

${ }^{3}$ Infra, IV, 2. 
II. Ownership in movables has so great a significance in the life of the individual that without this species of property he could not exist. This kind of property is of far less importance, however, for the community than the ownership of land. It is on this account, that land-law ownership has undergone a different evolution in many legal systems than ownership of movab!e property. The interest which the individual has in the legal control of movable things, such as food, clothing, arms, ornaments, household utensils, or animals, is everywhere provided with legal protection. This protection in its aspect of favoring the individual is, as a matter of social evolution, and as a fact of history, more ancient than individual ownership of land. Protection of movable things, however, is less intensive than of immovable things. It is subject to loss by shorter limitations, and sometimes comes in close approach to the simple protection of possession with which in many systems it is even identical. ${ }^{1}$

III. Historically and politically, the right of ownership of land is of much greater importance than ownership of movable things. Considerations of the ethical value of ownership in general apply in the highest degree to ownership of land by individual physical persons. ${ }^{2}$ There is no period known to history when

${ }^{1}$ Cf. French Civil Code, art. 2279-80; Gundermann Englisches Privatrecht (1864), I, p. 310.

${ }^{2}$ W. Oncken, Die Stactslehre des Aristotoles, Bd. I, p. 192; Laboulage, Geschichte der Vereinigten Staaten (1868), Bd. I, p. 80. Cf. also, Emile De Laveleye, De la propritte et de ses formes primitives, 2d ed. (Paris 1877): Kohler, in Krit. Viertel J. S. (N. F.), Bd. IV (1881), p. 24.

The report of the German consul Weber of Apia, on Jan. 22, 1879, to the foreign office at Berlin, is highly indicative of the ethical value of individual ownership. It says: "In Samoa the population is so small in comparison with the extent of aratle land; and nature has been so provident, that the natives are provided with bountiful satisfaction of their limited necessities without effort. Even though an increase may be seen in their wants, yet it will be a long time before the Samoan, in consequence of this, will be accustomed to any systematic labor. Horeover, with the advance of civilization, 
physical persons did not have individual ownership of land. There are, however, known periods and peoples in history where individual ownership of land was not the rule; where such ownership at the farthest extended to a place of abode (mansio) ${ }^{1}$; and where community ownership prevailed as to the remainder of the land. So long as hunting and fishing were the principal, or the only activities, and alone furnished means of subsistence, individual ownership, in an incomplete dispersion of population, was impossible. Even the pasturage of animals did not express any necessity for individual ownership. When cultivation of the soil began to prevail the necessity first asserted itself of giving recognition to private interests in cultivated land by legal protection of the individuals who tilled and sowed the land. A concurrent necessity of undivided community-land long and perhaps always remained.

This evolution, from the starting-point of community ownership of landed property, is shown by the history of German land-polity, ${ }^{2}$ even though the details of the

there must be overcome also certain communistic custonis which to a greater or less extent prevail among all Polynesian peoples. Even when the personal authority of the petty chiefs will no longer exist, the lower caste Samoan, in consequence of the respect for higher castes, which has become as second nature through the custorn of the country, will not easily be able to exclude one of such higher caste from access to anything which he desires, and much less a relative. Unconditioned personal ownership hardly exists in reality but mostly only family or kin ownership. As a result, motive and inclination to acquisition of personal ownership through personal effort are impeded from the beginning; inasmuch as no provision is made for the undisturbed use, or the free control of objects of ownership. Accordingly on these accounts agriculture does not exist among the Samoans."-Appendix to Memorial on the Samoan treaty of Jan. 24, 1879 (Reichstag publication, pp. 167, 168).

1 Maison, Hütte, Hof und Hofraum, Solstätte; the dwelling and its appurtenances.

${ }^{2}$ Cæsar, De Bell. Gall. IV, 1: Sed privati ac separati agri apud eos (sc. Suebos) nihil est.

VI. 22: Neque quisquam (sc. Germanorum) agri modum certum aut fines habet proprios; sed magistratus ac principes in annos singulos gentibus cognationibusque hominum, qui una coierunt, quantum et quo loco visum est agri uttribuunt atque anno post alio transire cogunt... 
duration of such ownership and the transitional steps are matters of doubt and controversy. ${ }^{1}$ While a complete transition has been effected toward individual ownership-whether of natural persons or of juristic persons-a transition that was frequently so accomplished, that the individual, in the interest of his family, remained in the background (without assuming, however, that so-called "family ownership" was the actual basis of the connecting link between original community ownership and modern individual ownership); yet notwithstanding the completeness of the change, there are not many legal institutions which do not clearly indicate the starting-point of the evolution of land ownership. ${ }^{2}$ This is to be asserted in particular

23: Civitatibus maxima laus est quam latissime circum se vastatis finibus solitudines habere. Hoc proprium virtutis existimant, expulsos agris finitimos cedere, neque quemquam prope audere consistere; simul hoc se fore tutiores arbitrantur, repentinx incursionis timore sublato.

Tacitus, Germ. 26: Agri pro numero cultorum ab universis in vices occupantur, quos mox inter se secundum dignationem partiuntur: facilitatem partiendi camporum spatia prabent. Arva per annos mutant: et superest ager: nec enim cum ubertate et amplitudine soli labore contendunt. ut pomaria conserant et prata separent et hortos rigent: sola terre seges in'peratur.

${ }^{1} \mathrm{G}$. Waitz places the beginning of stationary agriculture with individual ownership as early as the time of Cæsar (about 50 B.C.); and claims that there was complete settlement. with individual ownership prior to the tine of Tacitus (about 100 A.D.). v. Sybel claims a much slower progression toward individual ownership, and a later period for its establishment, as the rule. The position of $\mathrm{v}$. Sybel has attracted the most followers: thus, Roscher, v. Inama-Sternegg, F. Dahn, and R. Schrōder.

${ }^{2}$ Thus the ancient farmstead-communities (Gehöferschaften) in the governmental district 'Treves (see Heusler. Inst. des deutschen Privatrechts, Bd. I, p. 294), and the woodland-communities (Hauberggenossenschaften) in the district Siegen (Heusler, ib., 295). Cf. the Prussian statute of March 17. 1879. p. 228 and particularly, secs. 2, 6, 7. The ancient German institution: of land ownership are comparable to the Russian Mir, or collective possession of property by the village community with distribution of the communityland among individual families, tiaglos; opposed to which is private ownership in the Izba (mansio). They are also comparable to the Javanese dessa, or community property (in rice fields) which is apportioned anong individual families, Sawchs, for a term of years: also to the East Indian institution of community ownership of land; and finally, to the Mexican communities, calpulli. See as to all of these, Laveleye, op. cit., 27, 49: Kohler, Krit. v. J. Schrift (1881), pp. 8, 28: and Heusler, op. cit., Sec. 56. Here also are to he mentioned the Slavic Zadruga (sec. 7, note 3, p. 53, supra), and the com. 
of the common, the undivided lands of the mark association (the marca) ${ }^{1}$ which in early times (that is before the migration of the peoples) embraced even agricultural land, ${ }^{2}$ and afterwards only forest and pasturage. This may be claimed far more, to the extent that ownership of the common has passed over to the community, and $a \mathrm{such}^{3}$ is yet to be recognized. The same is true

munistic aspect of the primitive civilization of the Samoans and Pelew islanders (p. 97, note 1, and p. 140, note 2).

[See Dr. D. W. Ross, The Early History of Land-Holding among the Germans, and numerous references therein entered.]

${ }^{1}$ Lörsch and Schröder, Urkunden (2d ed., 1881); No. 20 (pascuarium in communi marca, 7th century); No. 79 (silva communis, 10th century); No. 117 (silva indivisa, 13th century), etc.

2 Heusler, op. cit., p. 263 . It may be taken as proved by Schröder that the strict agricultural land-community (Feldgemeinschaft) was still the basis of the agrarian constitution of the Salic Franks in the 6th century. (Rich. Schröder, Die Franken und ihr Recht, Weimar, 1881, pp. 55, 61: also Schröder, Die Ausbreitung der salischen Franken: a contribution to the history of the German agricultural land-community (Feldgemeinschaft) Forschungen XIX, p. 144. Schröder, however, makes an exception of Salgüter (lordly property alongside of al'otments of the inhabitants of marks). The exception, as favoring the farmstead system (Hofsystem), may well admit of wider extension; even if not as far as is supposed by v. Inama-Sternegg in opposition to Schröder, that it may be regarded as the basis of the Frankish agrarian constitution. [See D. W. Ross, op. cit., whose position agrees with InamaSternegg.]

Tacitus says of the farmstead system, Germ. 16:-

Nullas Germanorum populis urbes habitare satis notum est; ne pati quidem inter se junctas sedes; colunt discreti ac diversi, ut fons, ut campus, ut nemus placuit; vicos locant non in nostrum morem, connexis et cohorentibus adificiis; suum quisque domum spatio circumdat, sive adversus casus ignis remedium, sive inscitia adificandi.

It was a necessary consequence of the influence of the form of the earth's surface and the social or national evolution, attained during the settlement of the tribes and the starting of agriculture, that the establishment of the agricultural village community system (Dorfsystem) according to mark law should have become a prominent or exclusive institution on the plains and the great arteries of travel, whether along the Roman military roads, or important waterways. This was equally true of the peoples who still had communication with the Romans, as in the case of the Franks. It also resulted however, that in mountainous territory and mountain valleys remote from such lines of communication and avenues of civilization-as in Rhætia, among the Marcomonni and the Goths, in South Bavaria, and in Tyrol especially-there prevailed the farmstead system as Tacitus described it, and the law of service about kingly villas and castles of lords (Dienstrecht).

${ }^{3}$ Individual ownership carved out of the common included the home itself, and later included also agricultural land and meadow and was called (Austrian) Gesund and (Bavarian) Point, Peint, and Bannt. 
of the Alpine associations where it may be noted as of special importance that they are not always coincident with communities, but also arise out of primitive capitalistic associations. ${ }^{2}$

IV. The content of the right of ownership is derived from the more extensive notion: legal control of a thing in the totality of its connections.

1. This content is protected, apart from self-help and similar means, by proprietary actions which positive law classifies as:-

(a) The action of an owner against a possessor, where there is a complete interference with ownership by a deprivation of possession. Among the Romans this action with strict requirements of proof of ownership was called, rei vindicatio; or without the formal requirements of proof, actio Publiciana in rem. In German and other modern $l a w^{2}$ there is a presumption of ownership in favor of a possessor in good faith, unless the possession relates to a thing stolen or otherwise acquired against the will of the owner;

(b) The negatorial action (actio negatoria) based on partial interference with ownership. ${ }^{3}$

2. As above observed, the sphere of ownership is limited by the rights of other persons. Apart from jura in re aliena, these limitations are principally upon use and alienation. The owner is limited in his use by a consideration of equal rights of his neighbors, as in the case of legal limitations on ownership 4 or so-called legal servitudes, ex jure iicinitatis; and also by regula-

1 Heusler, op. cit., p. 295.

2 B.G.B., secs. $985,1006$.

$3 \mathrm{Ib}$., sec. 1004. [There is no equivalent in our law for this action. Actio negatoria protects an owner against a mere disturbance of possession. If the interference is of a recurring nature the owner may have an injunction if permanent he may require the disturber to remove the injury: and in other cases he may have damages. See Savigny, System d. Róm. R. VI, 349: Sohm, Inst. 249; Schuster Prirciples Ger. Civil Law, 410.]

ib. sec. 906 . 
tions which are directed to the protection of the public interest ${ }^{1}$ - the state, the community, or even the interest of the family - as opposed to the interest of ownership. ${ }^{2}$.

The alienation of landed property is distinctly limited in the German law. This limitation on ownership arises in part from the fact that individual ownership of land in Germany, as shown, has evolved out of community ownership. This is also in part due to the circumstance that family interests in land have received a special and peculiar legal protection as against individual owners. Based on these reasons, the legal institutions of family settlements or ancient patrimonial estates, and family fidei-commissa ${ }^{3}$ arose. This was also the origin of Beispruchsrechte [which required consent of the blood relatives before landed property might be transferred in the lifetime of the owner, and in the absence of which, the relatives could within a year and a day claim the property as if inheritance had followed death-retractus gentilicius sive ex jure consanguinitatis]; and Retraktrechte (Näherrechte) [the power to require the relinquishment from the transferee or any subsequent grantee, of land transferred upon payment of the original purchase price.] ${ }^{4}$

V. The acquisition of ownership. This is based on juristic facts. Following are those juristic facts consisting of acts of persons which produce the acquisition of ownership:-

1. Appropriation (occupatio). ${ }^{5}$ This is the most natural method of acquiring possession. Persons, that

${ }^{1}$ Cf. B.G.E., sec. 904.

2 Stobbe, Deutsches Privatrecht, sec. 85; Gerher, Dtsch. Privatr., sec. 86 . Gengler, Dtsch. Privatr., sec. 48; Bluntschli, Dtsch. Privatr., sec. 87; Gareis, Grundriss, secs. 65-67.

${ }^{3}$ Gareis, Grundriss, secs. 62, 63; Einf. G. z. B.G.B., Art. 59.

${ }^{4}$ Literature, see Gareis, Grundriss, sec. 64; Stobbe, Deutsches Privatrecht, secs. 87-90: H. O. Lehmann in Birkmeyer's Enz., pp. 315, 316, 326, 357.

${ }^{5}$ R.G.B., secs. $958-964$. 
is natural legal subjects, become masters of the things of the earth, simply because they appropriate them, that is, take possession of them, and actually "apprehend" them with the will to become owner of them. It is self-evident that an unlimited exercise of acts of appropriation would lead directly to continual strife of all against all, if this egoistic tendency were not legally limited and legally surrounded by special conditions.

Of such conditions are:-

(a) That the thing ${ }^{1}$ to be appropriated shall be without an owner, as only res nullius cedit primo occupanti; thus, the law of stranded things (Strandrecht). Occupation of a thing against the will of the owner is theft, robbery, embezzlement, etc.;

(b) The observance of certain rules in the occupation of ownerless things as developed in the following departments of law: the law of mining, ${ }^{2}$ to which belong also salt-mining and pearl and amber fishery; the law of hunting ${ }^{3}$; the law of fishery ${ }^{4}$; the law of treasure-trove ${ }^{5}$ (Schatzheberecht, motio thesauri), and the law of finding ${ }^{6}$ (Finderrecht);

(c) Under certain conditions, however, occupation of things already possessed by an owner is legally permitted: thus-apart from the sovereignty of states over things ${ }^{7}$-occupatio bellica, or the taking by force in war, and occupation of means of subsistence by necessity of war (Requisitionsrecht); and the taking and destruction

\footnotetext{
1 Possibly there belongs here, the acquisition of ownership of lands by means of breaking the soil as by grubbing wild lands (cf. supra, sec. 7. II) whether in the case of lands theretofore belonging to the common or in the case of abandoned lands, and called by Lörsch and Schróder, Urkunder.(No. 128 of the year 1248)-agris in vepres et spineta redactis.

${ }^{2}$ Cf. Finf.G. z. B.G.B., Art. 67, 68.

${ }^{3} C f$. id., art. 69.

Id., art. 69.

B B.G.B., secs. 984, 1040.

${ }^{6}$ Id., secs. 965-983.

${ }^{7}$ See infra, secs. 37, 47.
} 
of things in case of necessity for self-help or self-defense in time of peace. ${ }^{1}$

2. Transfer of ownership ${ }^{2}$ (traditio, transfer of possession with animus tradendi, dominii transferendi). The Roman transfer of ownership by traditio has not been assimilated either in the older, or the modern law of Germany as to landed property. As a general rule, there is necessary a formal act of conveyance by agreement (Auflassung) which is consummated by record in a public registry or land-book ${ }^{3}$; so that he only is the legal owner who is registered as such in the land-book (Grundbuch). There is not to be confused here the law relating to registered agreements for the conveyance of land and the wholly independent provisions relating to agreements for the conveyance of land executed with judicial or notarial formalities and which carry the obligation of making such registered conveyances; as for example agreements for the sale of land. ${ }^{4}$

1 B.G.B., secs. 227-231, 859, 904.

Necessity is also taken into account by the present German Criminal Code (sec. 54; Gareis, Keichsges., 143-146). An example may also be found in the ancient Indian law: "A twice-born man, who is traveling and whose provisions are exhausted, shall not be fined, if he takes two stalks of sugar-cane or two (esculent) roots from the field of another man."-Manu VIII, 341. Cf. Jolly, Recht und Sitte, op. cit., p. 126. There is a German legal saying, "three are free"; thus in the Longobardian Law (Leges regis Kotharis, A.D., 643, cap. 301), it is provided: si quis super tres uvas de vinea aliena tulerit, componat solidos IV, nam si usque tres tulerit, nulla sit ei culpa. It is provided in the Saxon Mirror (Sachsenspiegel II, 68): Erligt deme wekvertigen manne sîn phert, her mûz wol korn sniten und ime geben, alsô verne als erz gereichen mag stênde imme wege mit eisne vîze; her en sal es aber nicht dannen vuren.

This provision suggests what Nachtigall says of African law: "There are customs even among the Fezzians which permit every person by force of law to pluck and gather for use on the spot ripe fruits as long as dates are not ripe for cutting, but he may not carry the fruit home."-Dr. G. Nachtigall, Sahara und Sudan, I, p. 269 (1879). See also, O. Gierke Ier Humor im deutschen Recht (1871), p. 9, note 19. Cf. also, the King's Peace, l'rederick I, 1156 , cap. 19.

2 B.G.B., secs. 929-936.

3 The ancient Greek law recognized recorcis of land rcgistry and publicity in the conveyance of immovable property. See, Lipsius, Leipzig Rectoral Address, 1893, pp. 12-13. See B.Cr.B., secs. 873-902, also, secs. 925-928 and the Ger. Land Registration Act of March 24, 1897 (G.E. A. II, 16 (208); also, H. O. Lehmann, in Birkmeyer's Enz., p. 314 and Bernhöft, pp. 517-540.

- B.G.B., sec. 313 . 
3. Acquisition of ownership by means of natural additions of objects of ownership to things already owned: thus the different kinds of accession, accretion, ${ }^{1}$ incorporation (incedificatio), ${ }^{2}$ the growth and separation of natural fruits. ${ }^{3}$ Confusion and specification $^{4}$ (confusio and specificatio) may also be considered here in part.

4. Usucaption, ${ }^{5}$ that is, the acquisition of ownership by means of possession of a particular character and for a certain duration. Time here, as in other cases, has a healing or perfecting force as a juristic fact. ${ }^{\circ}$

5. Expropriation. ${ }^{7}$ In particular cases, the interest of the community demands the termination of legally protected relations and the establishment of new rights. Expropriation is the justification of the public interest by means of a definite procedure based on a judicial decree through which the paramount position of the public interest over private right is adjudged. This procedure displays the operation of state sovereignty in the social purpose of private law.

6. Various other methods of acquisition of ownership, including the law of inheritance (sec. 34).

VI. Ownership may be extinguished in a particular individual where a complete transfer of ownership is made to another; likewise when the interest of the owner ceases to have protection, as by destruction by law; and absolutely as when the thing itself is destroyed or becomes extra commercium.

${ }^{1}$ Cf. Einf.G. z. B.G.B., Art. 65.

2 B.G.B., sec. 946.

${ }^{3}$ Id., secs. 953-957.

Id., secs. 946-952.

3 Usucaption of movahles, B.G.B., sec. 937-945; of immovables, secs. $900,927$.

- In the ancient Indian law (code of Manu VIII, 147) ten years' possession as owner creates owrership. Cf. also, Julius Jolly, Fecht und Sitte, op. cit. p. 91.

${ }^{7}$ Cf. supra, sec. 14, IV, 5; Einf.G. s. B.G.B., Art. 109. 


\section{SECTION 21}

\section{REAL RIGHTS ${ }^{1}$ in re ALIENA}

(Jura in re Aliena) ${ }^{2}$

It is possible that a person may have an interest in a thing in only a single connection or aspect while in all other aspects it may be subject to the use of another. For instance, one who has a right of way through the land of his neighbor without any rights in the fruits of the land, has a jus in re aliena so far as his interest in the right of passage is protected.

In this class of real rights, the immediate object of legal control is also a thing. Yet there may possibly also be exacted active duties of persons; as was provided for in great detail in the Roman law; and very extensively also in the German law, as in the case of perpetual charges on land (Reallasten), and in the law of tenure (Lehenrecht).

\footnotetext{
1 [ Jura in rem are classified by German writers into rights peculiar to the person (Persönlichkeitsrechte) and into real rights, or rights relating to tangible objects (dingliche Kechte). There is no compact term in German juristic terminology to designate rights with an intangible thing as a basis. The author divides the law of things into the law of material things which embraces real rights, and into the law of immaterial things which embraces rights peculiar to the person, including patent-rights, copy-rights, etc. See appendix to this work; Schuster, Principles of Cierman Civil Law (1907) p. 67.]

[In a wider and in what appears to be a more logically complete application for the purposes of complete classification, a jus in re aliena may be defined as an accessory proprietary right (whether in rem or in personain and whether relating to a material or an immaterial object) which limits another proprietary right in its possible legal uses. It is accessory to some right of the owner of the jus in re aliena. It is a right in a right. In this respect it is unlike a jus ad rem which is a right to a right. A jus in re aliena is intermediate between creative and extinctive facts without involviing transfer. Cf. sec. 20, note 1.]
}

${ }^{2}$ Salkowski, Inst., secs. 107-120; Sohm, Inst., secs. 55-59. 
In the recognition and development of jura in re aliena, economic conditions, and the political, and in particular, the socio-political history and circumstances of a people, have had great influence. Accordingly, in Germany certain jura in re aliena unknown to the Byzantine-Roman law also evolved alongside of such recognized real rights as servitudes and pledge-rights (Pfandrechte). In their entirety these rights are as follows:-

1. Servitudes ${ }^{1}$ (Dienstbarkeiten). These are rights of user recognized by the ancient Roman law-inalienable, and annexed to a definite person. ${ }^{2}$ Servitudes are classified, accordingly, as:-

(a) The owner of the usufructuary interest is a definite person (thus the citizen H., or the surviving widow of the peasant M.). This servitude is, therefore, fixed as belonging only to that person; in which case it can exist only so long as that person lives; or

(b) As the entitled subject is discovered or ascertained by his ownership of land, sometimes called entitled land, that is, the ownership of a predium dominans. ${ }^{3}$ The owner for the time being of the dominant land is the person entitled to the servitude.

These servitudes are therefore respectively called:-

(a) Personal servitudes: including the usufruct 4 (ususfructus, Niessbrauch) which has become an important

1 [This includes the easements and profits d prendre of the English law.]

${ }^{2}$ Cf. Sohm, Inst., sec. 56.

3 So called in distinction from pradium serriens, or land partially subject to use in the legally protected interest of the owner of the servitude.

Usufruct in things, B.G.B., secs. 1030-1067; of rights, B.G.B., secs. 1068 to 1084 ; of one's whole property, B.G.B., secs.1085-1089. Derivative or variant forms of usufruct:-

(a) Prebendiary rights (see Einf.G. z. B.G.B., Art. 80);

(b) Usufruct of the husband in the contributed property of the wife (B.G.B., sec. 1363), and the right of usufruct in the property of children, by virtue of parental power (B.G.B., sec. 1649):

(c) Real rights known as the "old man's part," life pensions, life annuities and rights of support (Einf.G. z. B.G.F.. Art. 96). 
right in the German family régime; and restricted personal servitudes such as usus and habitatio; ${ }^{1}$ and

(b) Prædial servitudes ${ }^{2}$ (Grunddienstbarkeiten). These servitudes, accordingly as they relate generally, but not exclusively, to urban buildings or improved lands (prcedia dominantia); or to land or forest in its economic use or employment, are again divided into:-

(a) Servitutes prcediorum urbanorum; as for example, servitus oneris ferendi; servitus tigni immittendi; servitus altius non tollendi; servitus stillicidii; servitus ne prospectui, ne luminibus officiatur; the easements of light, view, etc.;

(b) Servitutes prediorum rusticorum; such as rights of way (servitus itineris, servitus actus, and servitus via); water rights (servitus aquceductus, aquce hauriendce, dam rights, etc.); forest servitudes (forest privileges, fire-bote, wood-rights, litter-rights, foliage-rights) ${ }^{3}$ rights of pasturage (servitus pascendi, servitus compascendi, common pasturage, etc). . $^{4}$

Legal systems contain definite provisions relating to the content, range, acquisition, and extinguishment of these servitudes.

2. Pledge rights, Pfandrecht, pignus, hypotheca. This is a real right of security for a performance, or a burden upon a thing by its detention for a debt. ${ }^{5}$

In every right of pledge, the notion is practically employed that a thing shall answer or stand for a performance; to the end, that the satisfaction of a demand for this performance can be made out of the thing, as by sale of the thing pledged. ${ }^{5}$

I B.G.B., secs. 1090-1093.

2 B.G.B., secs. 1018-1029.

${ }^{3}$ Kraut-Frensdorf, Grundriss, sec. 101.

Id., sec. 99.

${ }^{5}$ There may also be a detention of a person to answer for a performance. See infra, sec. 22; cf. Tumer, Freiheitsverpfändung (altbabyl. Rechtslehre, Kohler u. Prinz), IV, p. 47. 
Modern law recognizes two essential classes of such pledge-rights :-

(a) Right of pledge of land commonly called hypotheca ${ }^{1}$ ( $H y$ pothek) in which the creditor does not have possession of the thing pledged; but has the right to cause the sale of the land pledged, in the event, that the demand, for which the pledge is given, is not satisfied by payment at the proper time. The creation of a hypothek requires, at the present time, registration of the pledge in a public register, in analogy to registration of ownership. The remaining usual and commercial pledge-rights of immovables, classified in accordance as they are certified or not (certificated hypotheks (Briefhypothek) and uncertificated hypotheks ${ }^{2}$ (Buchhypothek)) are cautionary hypothecary charges ${ }^{3}$ (Sicherungshypothek), land charges ${ }^{4}$ (Grundschuld), and annuity charges ${ }^{5}$ (Rentenschuld);

(b) Pledge-rights in movable things ${ }^{\circ}$ (Faustpfand, pignus) which are delivered into the custody of the creditor. The chief application of pignus is in the business of loan or pawn establishments, ${ }^{7}$ and in commercial law. The Lombard business which is a peculiar combination of money lending and pignus, ${ }^{8}$ is a species of the kind mentioned. There is also to be mentioned bottomry. ${ }^{9}$ The creditor in a pignus transaction is also, to a certain extent, a debtor. He is bound, con-

1 ISchuster, op. cit., p. 436, calls this a "hypothecary charge," as opposed to a "land charge" (Grundschuld). The first is a charge on land accessory to a debt; the other is independent of the debt and enforcible without proof of the debt.]

${ }^{2}$ B.G.B., sec. 1113; Cosack, Lehrb. d. b. R., sec. 221.

${ }^{3}$ B.G.B., sec. 1184 ; Cosack, loc. cit., sec. 223.

- B.G.B., 1191; Cosack loc. cit., sec. 222.

s B.G.B., sec. 1199 .

6 The German Civil Code distinguishes: pledge-rights in movable things, secs. 1204-1258, and in connection with this title, pledge-rights in registered ships, secs. 1259-1272; and pledge rights in rights, secs. 1273-1296.

${ }^{7}$ Einf. G. z. B.G.B., Art. 94.

${ }^{8}$ See infra, sec. 22, 111, 6; Gareis, Lehr. d. H.R., p. 511.

${ }^{\circ}$ Gareis, loc. cit., pp. 715, 963. 
formably to obligation, to return the pledge after the termination of his pledge-right, and in particular, after payment of his claim. ${ }^{1}$

3. Tenure (feudum) is a real right in a thing whereby the person entitled (the vasallus) may make a certain use of a thing, and has a so-called dominium utile in a thing which must be one not consumed in use. In return, the vassal is bound to the feudal lord (dominus feudi) in a certain fidelity. In a true feud, this consisted of knight service, and in a base feud (feudastrum, feutum bursaticum, purse or money feud), consisted in base or socage service, tithes, and other perpetual charges, or in the payment of money. In modern times only a remnant of these Germanic, that is Frankish and Lombard legal institutions, have any practical significance. $^{2}$

4. Tenantry rights (Maier, and Kolonatrechte) which include real rights in farm lands, with a reservation of ownership in the dominus and requiring the payment of a fixed sum (canon, pensio, or perpetual charge) to the owner; and also, possibly, including uses of land passing by inheritance, such as heritable leases (Erbpachten). ${ }^{3}$

\section{Perpetual charges (Reallasten) are periodical} duties of performance on the part of the tenant of a servient estate. The right to such performance is, in

${ }^{1}$ See infra, sec. 23, III, 8 ; cf. B.G.B., sec. 1223.

2 Einf.G.z. B.G.B., Art. 59. The basis of feudalism in Germany lay partly in the system of household retainers of the nobles (see sec. 47, note 9, p. 249. infra); partly in the customary system of beneficia among the Franks; and in part in the legal institution of personal submission under definite fidelity, or vassalage. Regarding the feudal system in ancient Babylonian law, see Code of Hammurabi, secs. 32-37.

${ }^{3}$ Thus, the rights of peasant proprietors ( $\left.B \tilde{u} d n c r r e c h t e\right)$, of small tenant farners (Häuslerrechte), and of other hereditary tenants (Erbzinsrechte). See Einf. G. z. B.G.B., Art. 63 . See also Kolonatrechte, in Gareis, Grundriss, secs. 90, 91. Cf. infra. No. 6 .

B.G.B., secs. 1105-1112; cf. Gareis, Grundriss, sec. 87. 
general, of a real nature and rests upon the land itself. The land appears as bound for the performance of the duty. This right is also of a personal nature, in that the person, who was the owner at the time of the maturity of the periodical performance, is regarded as liable for the performance. Of this nature, also, are rent charges $^{1}$ of various kinds, including the institution of perpetual payment (Münchener Ewiggeli), tithes (deciine), socage service (Fronen), and possibly also, life pensions or annuities (Leibzuchtrechte). Proscriptive rights (Bannrechte) may be laid on land like perpetual charges (Reallasten), whereby trade rights are established within a refinite district (Bannmeile), against the residents or tenants of land within the district, requiring them to purchase such articles of consumption as are interdicted $;^{2}$ and whereby this duty of purchase is considered as a burden on the lands of the consumers.

6. Emphyteusis ( $2 v$ and $\Phi v \tau e^{\prime} \omega$ to implant) is a heritable lease (Erbpacht) of agricultural land (pradium rusticum), and called in this connection fundus emphyteuticarius. The emphyteutic lease has its origin, in part, in the legal relations growing out of the ager vectigalis of Rome; and, in part, arising out of legal conditions in connection with the imperial domains in Asia Minor. The emphyteuta, the lessee, is invested by his lease (contractus emphyteuticarius) with a right of possession, of usufruct, alienation, right of action, and various legal and possessory rights; just as in the case of an owner, as opposed to a mere lessee. His right is not a simple obligation right, but is protected against the whole world as a real right and passes by inheritance. The emphyteutic lessee was obliged under pain of expulsion to pay

\footnotetext{
${ }^{1}$ Concerning incumbrances for rent charges, see the Prussian statute of June 27, 1890 and Einf.G. z. B.G.B., Art. 62.

2 Einf.G. z. B.G.B., Art. 74: cf. Gareis, Grundriss, sec. 89.
} 
the owner (dominus fundi) a yearly compensation (vectigal, later called canon, or pensio, and corresponding to rent); to give formal notice of his intention to transfer his rights in order that the owner might exercise his legal right of pre-emption (jus protimiseos); and he was under duty not to injure the land. The principles of this letting have largely been assimilated in the German law of tenantry, (see No. 4 supra).

7. Heritable building rights ${ }^{1}$ (Erbbaurechte) are transferable and inheritable rights to erect buildings (for example a house, an outlook tower, a well, or a cellar) above or below the surface of the land. These rights are an incumbrance on land. They correspond, in part, with the Roman superficies, which is a real right in a building or other structure which stands on the land of another, and which, therefore, juridically is to be regarded as the property of the land owner. For this reason the superficiar has only a $j u s$ in re aliena ${ }^{2}$ in the building.

8. Beispruchsrechte, Retraktrechte, and Näherrechte ${ }^{3}$ are a species of other real rights which have been developed in the German law, by means of which a person may in certain cases make claim on things which another desires to transfer or has already transferred. Of this class, also, are the real rights of pre-emption (Vorkaufsrechte).

1 B.G.B., secs. 1012-1017.

2 The Roman right of superficies has come little into use in Germany. In local law, a legal institution has arisen whereby there may be different owners of different floors of a building in public houses. See contra, B.G.B. sec. 1014, but see Einf. G. 2. B.G.B., Art. 131, and 182. See also Sohm, Inst., sec. 58; Windscheid, Pand., Sec. 223.

${ }^{3}$ See supra, sec. 20 , IV, 2.

${ }_{4}^{4}$ B.G.B., secs. 1094-1104. The notion lying at the basis of Retraktrechte is of ancient origin; cf. Code of Hammurabi (ed. Kohler \& Peiser), p. 110, also by the same editors, Babylon. Rechtsleben, Bd. IV, p. 67; see also H. O. Lehmann in Birkmeyer's Enz., pp. 315, 316, 326, 357. 
9. Real possessory rights: hunting, fishery and mining rights.

10. Real legal relations in church law: prebendiary rights (Pfründnerrechte), advowsons (Patronatrechte), sepulture, pew rights, incumbrances for maintenance of schools and churches. ${ }^{1}$

1 Einf.G. z. B.G.B., 132, 133. 
CHAPTER III

\section{THE LAW OF OBLIGATIONS}

\section{SECTION 22}

\section{GENERAL PART'}

A person may have an interest in the performance ${ }^{2}$ of an act by another; thus, an act of payment. The person who is to perform an act may be obligated (bound, (verbunden)) by legal order to its performance. $\mathrm{He}$ is therefore called the obligor or debtor (debitor). The person who has the power by legal order to demand an act from the debtor is called the obligee or creditor (creditor). The object of control of the dominant legal subject (that is the creditor) is an act of the debtor. This act may consist of doing or refraining.

In another aspect, the object may be the person of the debtor himself, who owes the performance of the act, and stands liable therefor. The theoretical, and sometimes also practical, distinction between a performance and the debtor's answerability, ${ }^{3}$ does not, in the latter 'case in modern civilizations, involve the person of the debtor in the totality of his relations ${ }^{4}$ and activities;

${ }^{1}$ Salkowski, Inst., sec. 121; Sohm, Inst., secs. 66, 74, 75, 76.

2 B.G.B., sec. 241: "By virtue of an obligation, the creditor is entitled to demand performance by the debtor. Performance may consist also of forbearance." With reference to the duty of performance, see B.G.B., sec. 242 , $e$ seq.; default of the debtor, B.G B., secs. 284, 292; default of the creditor, B.G.B, secs. 293-304.

${ }^{3}$ Relative to this distinction, see v. Amira, Grundriss d. germ. Rechts, sec. 70; Gareis, H.G.B., 3d ed., p. 332, sec. 356, note 3; H. Brunner, Grundzüge d. D. R. Geschichte, sec. 50, p. 291.

4 In earlier stages of civilization, at any rate, the whole personality was involved; so that there was slavery for debt. or in any event private im- 
as in such case, the debtor would cease to be a legal subject, and would become a legal object, a thing, or a slave. Obligations involve only particular relations, or only one relation, with regard to an act; thus a doing (facere, committere, - a positive act) or a forbearing (omittere, omission, - a negative act). ${ }^{1}$

A person who is entitled to re-payment from another of a sum of money can claim only a single act-the performance of payment. A person entitled to delivery of a horse from another on payment of the purchase price can claim only a single act, namely, delivery. In the first case the money, and in the second, the horse are not within the control of the creditor, until performance hy the debtor. The claim is, in each case, against the person of the debtor (actio in personam, and not in $\mathrm{rem})$. It does not involve the totality of the debior's personality; but only a single activity, that of performance. If the submission of the will of the debtor were to extend further and involve his personality to the extent of legal subjection, the obligation would be regarded as immoral (contra bonos mores) - as leading to actual slavery, which is regarded as illegal in civilized countries.

There is a legal bond between the creditor and debtor, an ohligatio,- -a vinculum juris, ${ }^{2}$ - by which the debtor is bound to the creditor for performance. Every obligation includes:-

(1) A creditor side and a debtor side;

(2) A claim and a deht;

prisonment (arrest for debt in the house of the creditor, etc.). Cf. Code of Hammurabi, secs. 113-117, 151. In the Babylonian law the wife stood as security for debts of the husband and might be sold therefor.

${ }^{1}$ Paulus, de obl. et act., Dig. 1, 3, 44, 7.

Obligationum substantia non in eo consistit, ut aliguod corpus nostrum, aut servitutem nostram faciat, sed ut alium nobis obstringat ad dandum aliquid, vel faciendum, vel prestandum.

${ }_{2}^{2}$ Pr. I, de obligat. (II, 13).• Obiigatio est juris vinculum, quo necessitate adstringimur alicujus solvenda rei secundum nostra civitatis iura. 
(3) A right in personam ${ }^{1}$ and a legal relation involving a personal tie requiring one person to render performance to another (Schuldverhältnis);

(4) A personal title (Berechtigung) of the creditor and a personal tie (Verpflichtung) by which the debtor is bound to render performance.

There may be a plurality of creditors or debtors: thus joint creditors and joint debtors.

A creditor may transfer ${ }^{2}$ his rights (or the exercise of his rights) to another (a cessionarius) who then takes the position of the assignor (creditor cedens). All defenses avail against the assignee which the debtor could have made against the original creditor-(exceptiones ex persona cedentis).

The debtor cannot without the consent of the creditor completely transfer his liability.

Legal order provides for a dissolution of the obligatory bond (vinculum juris) of obligations, by performance of the duty involved.

The law of obligations requires a pre-determinable termination of the obligatory bond, in contradistinction to the law of real rights. The normal terinination of the relation is performance or solutio in the narrow sense. There may, however, be a termination of the bond not based on performance, but in which the obliga-

${ }^{1}$ [Forderungsrecht. This is a technical German legal term which goes back to the formulary system of classical Roman law. Every formula contained an intentio which specified the conditions or issue upon which the defendant was to be condemned. In actions in personam the defendant was designated in person, while in actions in rem only the person of the plantiff appeared in the intentio. The term "right" is here used in a generic sense to include "power." The term Schuldverhältnis (obligatory relation) also has a technical application and is here so employed.

It would seem that the elements of an obligation might perhaps be more logically contrasted in the following enumeration: (1) a creditor side, and a debtor side; (2) a claim, and a debt; (3) an interest to require a certain thing of a definite person, and a duty of a definite person to render a certain performance; (4) a power to require a certain thing of a definite person, and a liability of a definite person to render performance to another.]

${ }^{2}$ Transfer of claims by assignment according to B.G.B., secs. 398-419. 
tion yet comes to an end. ${ }^{1}$ This may result by confusio or merger, as when the debtor becomes the heir of his creditor; by rescission ${ }^{2}$ (Rücktritt vom Vertrag); and by release (Erlass). ${ }^{3}$

The law of obligations represents a higher stage of civilization than the law of things, or family law. It is less primitive and therefore susceptible of more irregular development than the other groups of law. In the evolution of the law of obligations, as seen in the modern law of banking, and of stock-exchanges, and moreover in commercial affairs, there is mirrored most conspicuously the historical progress of centuries made by the law and jurisprudence, and especially is this true in German legal history. ${ }^{4}$

The first step in advance, from the law of things and family law toward the law of obligations, was made in the recognition of claims for compensation or damages. Compensation for robbery, theft, and other illegal injury is indeed the first object which a free person may claim from another. ${ }^{5}$ Later, as a matter of legal history, there

\footnotetext{
1 Extinction of obligations by fulfillment, sec B.G.B., secs, 362-371; extinction by lodgment (Hinterlegung) (deposit by the debtor of money, etc. for the benefit of the creditor, in a public lodgment-office, at the place of performance],B.G.B., secs. 372-386; extinction by set-off (Aufrechnung), B.G.B., secs. 387-396. An unactionable claim may in certain cases exist (a so-called naturalis obligatio); cf. B.G.B., secs. 222 (2), 223, and G. Frenzel, Ueber die Entstehung des Römischen Rechtsbegriffs der naturalis obligatio (1897).

${ }^{2}$ B.G. B., secs. $346-361$.

${ }^{3}$ Ibid., sec. 397.

- Cf. Kohler, Z. S. f. vergleich. Rechtswissenschaft, Bd. III, p. 161.

5 It is a matter of controversy whether the Homeric age recognized an actionable obligation arising out of agreement. Obligations based on delicts certainly were recognized: of. Iliad XI, 685, 688; Odyss. XXI, 16 . The remunerated position of the watchman, however, (Odyss. IV, 525) is to be regarded as a bilateral agreement. Cf. A. Hofmeister, Die Gerichtsszene im Schild des Achilles (Iliad XVIII, 497-508) in Z. S. f. vgl. Rechtswissenschaft, Bd. II, pp. 442,446, 451. The most ancient law book that we know, the Code of Hammurabi, recognized as early as about 2250 B. C. a multitude of obligatory relations based on agreement; thus sale and warranty (like in the modern German law, see Kohler-Peiser, pp. 111, 112, 115); ordinary and usufructuary leases (Miete, and Pacht); agreements of suretyship or
} 
appeared the more important claim arising by force of agreement, with its complex development. This claim was based probably, at first, on the giving in pledge of a thing which was to stand as a wadium for performance; and later the giving in pledge of the person obliged or the person of another as personal security for a debt.

There are two chief sources of obligations:1-

(a) Obligations arising out of agreement (sec. 23); and

(b) Obligations arising out of unlawful acts (sec. 24).

guaranty (Bürgschafi); depository, transportation, and warehouse agreements (Verwahrungs- Transport- und Lagerhausvertrag); and the last as in modern law (see Kohler-Peiser, p. 116). This code even recognized instruments running to bearer (Inhaberpapiere) (ib., p. 117).

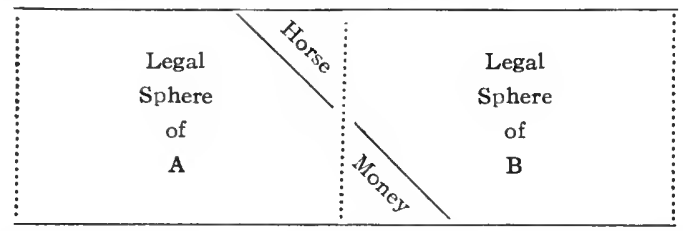

$A$ and $B$ agree that the horse shall pass from the legal sphere of $A$ by a transfer to the sphere of $\mathrm{B}$; and that the purchase price shall pass from $\mathrm{B}$ to $\mathrm{A}$. This is an obligation arising in agreement.

If $\mathrm{B}$ steals or illegally injures the horse of $\mathrm{A}$ he is obliged to pay a sum of money. This is an obligation of delict. 
(a) OBLIGATIONS ARISING OUT OF AGREEMENT!

I. An agreement (Vertrag) is a declared concurrence of will (erklärte Willensübereinstiminung) of two or more persons whereby a change in their legal spheres is intended. An obligation generated by agreement is a declared concurrence of intention as a result of which one person is bound to another for a performance, (Leistung). Not every concurrence of intention designed for the origination of such obligatory bond, does, in fact, create it; but only those permitted by law. Even though a concurrence of intention may be allowed by law, this, alone, is not sufficient to originate a legally actionable claim. Only those agreements legally recognized as actionable can create actionable claims. ${ }^{2}$

${ }^{1}$ Salkowski, Inst., secs. 135-149; Sohm, Inst., secs. 65-71; B.G.B., secs. 305-808.

${ }^{2} C f$. on the other hand, agreements for hribery, seduction, robbery, concubinage, agreements contrary to the Trade Regulation Statute (sec. 115), agreements to the prejudice of creditors (contrary to $R$.G. July 21, 1879), usurious agreements (contrary to $R . G$. May 24, 1880), and agreements contrary to the provisions of the Accident Insurance Act (July 6, 1884). Such agreements are declared against, by positive law, because they are contrary to morals, or statute, or both. Informal agreements, such as agreements for the conveyance of land, for charging lands with hypothecary liens, the formation of share companies, registered associations, and informal bills of exchange, are denied recognition in the law, in that they do not comply with the statutory requirements of form. Acts in the law contrary to good morals, are void (B.G.B., sec. 138); also such as are contrary to statutory prohibition (B.G.B., sec. 134), and such as are deficient in the requirements of statutory form (B.G.B., sec. 125). The German Civil Code, with reference to obligations arising out of agreement, is based on the principle of free capacity of persons to regulate their relations so far as this capacity is not interfered with by particular statutory prohibition, as for example, in B.G.B., secs. 134-138, 312. With reference to the origination and scope of agreements, sec B.G.B., secs. 305-319; bilateral agreements, B.G.B., secs. 320-327; agreements for the benefit of third persons, B.G.B., secs. 328-335.

[The term, agreement, is here used in a generic sense, as including all bilateral acts in the law.] 
II. The law of obligations as already observed is the product of a high stage of civilization. In earlier periods of legal evolution, agreements were obligatory and actionable, only upon the observance of very precise forms. Ethical necessity early made itself felt when the saying "a man of his word" was adopted as a badge of honor. Alongside of agreements valid for the sake of their form, agreements sprung up in an early period of history which on one hand touched what is indispensable to every man, trust and confidence (fides); and on the other, agreements which afforded a greater degree of protection for realizing the will of the contracting parties than the strict frame of formal agreements. Out of this evolved the following distinction:-

$(A)$ Formal agreements, or such agreements as possess obligatory force and actionability only by virtue of their precise form and only so far as the form extends.

The following are examples of formal agreements:-

The ancient Roman nexum, a ceremonial weighing of coins, per ces et librain, which was a formal act accompanied by declaratory words; the stipulatio, and dotis dictio-ancient Roman verbal contracts entered into with the use of ceremonial words of obligation;

Acceptilatio and expensilatio-ancient Roman literal contracts concluded by a formal entry in writing of a claim (nomen transcripticium), in the domestic registers of the creditor and the debtor.

While these formal contracts lie within the domain of legal antiquity, yet the law recognizes:-

(a) Abstract agreements which are valid without any actual basis of liability, that is, regardless of the absence of any material causa ${ }^{1}$ [ground of liability recognized by law]; provided a definite form is pursued. These agreements, accordingly, are called formal agreements and

1 [See Salmond, Jurisprudence, 2d ed., p. 320.] 
are recognized in abstract promises of performance (Schuldversprechen) ${ }^{1}$ and abstract acknowledgments of obligation (Schuldanerkenntnis) $;^{2}$

(b) Literal contracts of the modern law which are of great practical importance in the law of securities (Wertpapiere), and pre-eminently in the law of bills of exchange (Wechselrecht) ${ }^{3}$

(B) Substantive agreements (Materialverträge), that is agreements which derive their import not from the form of declared intention; but from the content of a declared concurrence of wills (the special causa of the agreement) of the parties."

In entering into these so-called substantive contracts, there may legally be necessary the observance of a certain formality for the avoidance of invalidity. Thus, in the ancient German law, "he, who would be bound to another, formally declares his binding intention, not simply by words, but by delivering a symbol, a festuca, a wadium, an arrha, or a record by which his intention is indicated, or by paying a small sum of money (arrha, denarius dei, denarius sancti spiritus, a God's penny, a token of the Holy Ghost, or an earnest penny), or by fortifying his promise by a handshake, or by employing certain ceremonial words, as an oath or other traditional forms. The agreement of the parties may also require, for binding form, the calling of witnesses to their agreement, and after the conclusion of the agreement, a social meal or drink (Litkauf, Leikauf, mercipotus, Weinkauf)"-Stobbe, Hdbch. des deutschen Privatrechts, Bd. III, pp. 62, 63.

: B.G.B., secs. 780, 782: Cosack, B.R., sec. 162.

${ }^{2}$ B.G.B., secs. 781, 782: F. Endemann, Lehrb. d. b. R., sec. 194.

${ }^{3} C$. Thöl, H.R. Bd. II: $W . R$. (4th ed.). sec. 17 , note 1 , sec. 96 (p 345 ). sec. 97 (p. 351): Windscheid, Pand., sec. 364.

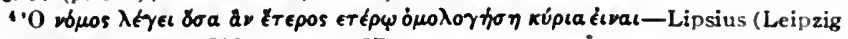
Rectoral Address (1893), pp. 11, 27).

s Earnest money and stipulated penalties, B.G.B., sec. 336. 
Modern German law also requires, although only exceptionally (see note 2, p. 162), certain formalities in the conclusion of substantive agreements which in the absence of these forms are invalid; thus in agreements relating to immovables (sales of such, or the creation of Hypotheks); and in the establishment of certain partnerships.

In other cases, - and this is now the general rule,--the conclusion of substantive agreements does not require the observance of any particular form. They are held valid when they may be inherently so regarded, to the extent that the parties intend, according to their declaration of intention; whether verbal or in writing; and whether express or by indicative acts. In certain cases a declaration of intention may be manifested also by (negative) acts of silence. ${ }^{1}$

The Roman law, and also the German law, developed only by progressive steps to the point of recognizing informal agreements (pacta, pacta nuda) as productive of actionable obligations. In certain varieties of agreements, this operation was allowed on the ground of performance by one party of his part or res. Thus, for the purpose of securing the return (restitution) of a thing, or an equal quantity of a thing of the same kind given over to another, there arose an actionable obligation. These agreements were called real contracts and were of the following varieties: mutuum, depositum, commodatum, and pignus. Later, other forms of real contracts, called innominate contracts became actionable; thus, do ut des, etc.

By force of the necessities of commerce, the ancient Roman law recognized, in four very important cases, a binding and actionable obligation in purely informal

${ }^{1}$ Cf. H.G.B., sec. 362 (1). 
deciarations of intention (nudus consensus); thus, emptiovenditio, locatio-conductio, mandatum and societas.

The principle of these consensual contracts pressed continually forward. The Roman imperial law recognized a large number of actionable pacta (pacta vestita). In modern law, all such agreements are valid if inherently valid, even though informally concluded; unless, as in exceptional cases, the statute otherwise provides.

\section{Survey of common agreements.}

1. Sale ${ }^{1}$ (emptio-venditio) is a consensual agreement whereby one party the seller (venditor) is obligated to deliver a thing (merx) to another, the buyer (emptor), upon payment of a price (pretium).

2. Alongside the agreement of sale (Kaufvertrag), which was preceded historically by exchange ${ }^{2}$ (Tausch) or barter, are the related commercial activities dealing with securities and transactions affected by the element of time (Fixgeschäfte): [purchase and sale of commodities and securities on a stock exchange consummated by payment of the difference in market price within a fixed period, and not by delivery of the commodity or security (Differenzgeschäft) $;^{3}$ reservation of a right, upon payment of a premium; to withdraw from a contract relating to securities, or to alter its terms in a definite

\footnotetext{
1 Consonant with the development above noted in which originaliy the giving of credit was unknown, sale, primitively, was a cash transaction. Where the transaction was not one for cash the purchaser at the time of the sale either gave a pledge (wadium), or a bond acknowledging indebtedness, in which the purchaser obligated himself to pay the seller a sum of money. equal to the purchase price as a loan. The former was the early German method, and the latter the ancient Babylonian institution. See Sohm, Inst., sec. 69 (1); Salkowski, Inst., secs. 141, 142; B.G.B., secs. 433-514; Cosack, B.R., sec. 121. Regarding commercial sale, see Gareis, in Endemunn's Handbch. d. H.R., Bd. II, sec. 258; H.G.B., secs. 373-382; Gareis, $H$. R., secs. 45-49.

2 Odyss, I, 183; B.G.B., sec. 515; Cosack, B.R., sec. 133; Gareis, H.R., p. 30.

${ }^{3}$ B.G.B., sec. 764; Bourse statute, secs. $66-69$; Gareis, H.R., sec. 48, II; Cosack, H.R., secs. 77, 78 .
} 
manner (Prämiengeschäft);' agreements deferring settlement the consideration for which is called on the English stock exchange, contango, (Reportgeschäft) $;^{2}$ agreements to transfer the proceeds of a particular drawing in a premium lottery (Promessengeschäfte), ${ }^{3}$ also called Hoffnungskauf]: the business of. stock exchanges and bourses $^{4}$ (Börsengeschäftc).

3. Letting and hire agreements ${ }^{5}$ (Sachmiete, locatioconductio rei) are agreements for cession of the use of things upon payment; as, for example, the lease of a house, of a wagon, of books. A lease of the use of a thing with enjoyment of the fruits, is called a usufructuary lease ${ }^{6}$ (Pacht).

In many systems of law, as for instance, in Austria, a usufructuary lease may under certain conditions produce a real effect. The rule "sale breaks the lease" ("Kauf bricht Miete") which prevailed under the German common law, was supplanted by the civil code as it already had been before by the Prussian Landrecht. It is now the general rule, that when leased land is conveyed by the lessor to a third person, the grantee stands in the position of the lessor as to rights and duties flowing out of the ownership of the lessor (B.G.B. sec. 571).

4. Mandate ${ }^{7}$ (mardatum, Auftrag). One who accepts from another (mandans) a mandate is bound to execute his commission in conformity with the mandate, and with due care. A corresponding performance, as remuneration or payment, is not essential in mandate, and for this reason, it is distinguished from remunerated and unremunerated agreements for service.

1 Cosack, H.R., sec. 79; Gareis, H.R., sec. 48, IV.

${ }^{2}$ Cosack, H.R., sec. 80 ; Gareis, H.R., p. 378 , sec. 48 , III.

3 Gareis, H.R., pp. $383,384$.

( Bourse statute (June 22, 1896); Cosack, H.R., scc. 345; Gareis, H.R., sec. 49.

${ }^{5}$ B.G.B., secs. 535-580; Cosack, B.R., sec. 134.

- B.G.B., secs. 581-597; Cosack, B.R., sec. 136.

${ }^{7}$ B.G.B., secs. 662-675; Cosack, B.R., p. 529. 
j. Partnership agreements ${ }^{1}$ (Gesellschaftsvertrag, Societcis) wherein two or more persons mutually obligate themselves to performances; whether based on capital, labor, or both; with a view of accomplishing a common purpose.

Partnerships (Gesellschaften) may be variously classified according to their objects, and according to the method of their origination. Classified according to their objects, they may be mercantile partnerships (Erwerbsgesellschaften, societates quastuaria) and also such as have no industrial ends, such as religious, scientific, and art associations. To the first class belong all commercial partnerships (Handelsgesellschaften) which according to the method of participation in the business of the partners, or according to their liability may be:-

(a) Partnerships of unlimited liability ${ }^{2}$ (offene Handelsgesellschaften);

(b) Commandite partnerships, ${ }^{3}$ and commandite partnerships with shares;

(c) Share companies ${ }^{5}$ (Aktiengesellschaften).

Other partnerships now legally recognized are dormant partnerships; ${ }^{\circ}$ joint adventure partnerships? (Gelegenheitsgesellschaften.) ${ }^{8}$ also called speculative associations; guilds; registered societies (eingetragene Genossenschaften $; ;^{9}$ limited liability partnerships; $;^{10}$ colonial partnerships; ${ }^{11}$ and mutual insurance societies. ${ }^{12}$ Under

1 B.G.B., secs. 54, 705-740; Gareis, H.R., sec. 61.

2 H.G.B., secs. 105-160; Cosack, H.R., sec. 105; Gareis, H.R., secs. 25-28.

${ }^{3}$ H.G.B., secs. 161-177; Gareis, H.R., sec. 30; Cosack, H.R., sec. 111.

H.G.B., secs. 320-334; Cosack, H.R., sec. 123; Gareis, H.R., sec. 37.

5 H.G.B., secs. 178-319; Gareis, H.R., secs. 31-36; Cosack, H.R., sec. 114.

6 H.G.B., secs. 335-342; Gareis, H.R., sec. 29.

7 Gareis, H.R., p. 114.

8 Trade statute, secs. 81-100; Gareis, L.ehrb. H.R., p. 319.

- Statute May 1, 1889; Gaieis, H.R., p. 114, sec. 38; Cosack H.R., sec. 224.

${ }^{10}$ Statute April 20, 1892; Gareis, H.R., sec. 39; Cosack, H.R. secs. 122.

"Statute March 15, 1888 and July 2, 1899; Kolonialzeitung (1899). No. 26, p. 225; Gareis, H.R., 319, 320.

12 Gareis, H.R., sec. 39a. 
certain conditions, there may be societies which externally, that is in relation to persons in society, may have the character of juristic persons. Of the religious associations, the most important are the churches, which are dealt with by church law. ${ }^{1}$

6. Loan of fungibles ${ }^{2}$ (mistum, Darlehen) in which the borrower is obliged to return to the lender, at a stipulated time, the same quantity of fungible things of equal quality (tantundumejusdem generis), as he received; with interest if provided by accessory agreement; and also with compensation for delay by virtue of the statute.

Loans of fungible things are the juristic basis of the savings-bank business, ${ }^{3}$ of banks of deposit and loan, ${ }^{4}$ the Lombard business, ${ }^{5}$ the Hypothek business, ${ }^{6}$ and of bottomry. ${ }^{7}$

7. Agreements for deposit ${ }^{8}$ (Verwahrung, depositum) in which the depositary (depositarius) to whom a thing is delivered for deposit for reward, ${ }^{9}$ or without reward, is bound for the return of the thing deposited, in good order to the depositor.

Agreements for deposit are the juristic basis of the commercial warehouse, safety deposit and public warehouse business. ${ }^{10}$

8. Agreements for gratuitous $\operatorname{loan}^{11}$ (commodatum, Leihe) bind the person to whom the loan is gratuitously

${ }^{1}$ See supra, sec. 15 , Nos. 1, 5, 6 (juristic persons), and infra, sec. 57 (church law); B.G.B., sec. 89: Einf.G., Art. 84-87.

${ }^{2}$ B.G.B., secs. 607-610 cf. Gareis, H.R., sec. 63 .

${ }^{3}$ Gareis H.R., p. 512.

"Gareis, H.R., sec. 63, Vli.

${ }^{5}$ Gareis, H.R., sec. $63, \mathrm{~V}$; Cosack, H.R., sec. 64.

${ }^{6}$ See supra, sec. 21, No. 2; cf. Gareis, H.R., pp. 33, 512.

7 H.G.B., secs. 679-699; Gareis, H.R., sec. 114; Cosack H.R., sec. 72.

8 B.G.B., secs. 688-700. Cosack, B.R., sec. 154.

${ }^{9}$ B.G.B., sec. 689; Gareis, H.R., sec. 42, VIII, sec. 60, sec. 63, VI.

${ }^{10}$ Statute relating to deposit of securities of July 5, 1896; Cosack, Lehrb.

d. H.R., sec. 100; Gareis, Lehrb. d. H.R., sec. 60 .

${ }^{11}$ B.G.B., secs. $598-606$ 
made (cominodatar) to return the thing loaned after its use has been completed.

9. Pledges of movables (pignus, Faustpfandvertrag) bind the pledgee to return the thing pledged on satisfaction of the debt, or upon other termination of the right of pledge.

10. Gifts. ${ }^{2}$

11. Wagering agreements; ${ }^{3}$ agreements relating to lotteries, ${ }^{4}$ and marine insurance ${ }^{5}$ and other aleatory agreements. ${ }^{\circ}$

12. Gaming agreements. ${ }^{7}$

There is a large group of agreements which lies between agreements for services (Dienstiertrag) ${ }^{8}$ and agreements for work looking to a definite result (Werkvertrag) ${ }^{9}$ This group (called Arbeitsverträge) has developed into the following commercial agreements: ${ }^{10}$

13. Commission agreements $;{ }^{11}$

14. Forwarding agreements $;{ }^{12}$

15. Carriage ${ }^{13}$ and inland navigation ${ }^{14}$ agreements;

16. Transportation and railroad agreements $;^{15}$

1 B.G.B., secs. 1215-1219, 1223, 1232.

2 B.G.B., secs. 516-534. Judicial or notarial authentication is necessary except in case of immediate performance, B.G.B., sec. 518.

${ }^{3}$ B.G.B., sec. 762 . Agreements of wager on futures or a difference in market values are protested (see note $3, p .166$ ) except in the case of persons registered in the bourse register. See Bourse statute of June 22, 1866, secs. 66-69; Gareis, H.G.B., p. 458, note 6, Art. 14, and Einf.G. z. H.G.B.; Gareis, H.R., pp. 391-393; and Cosack, H.R., sec. 78.

${ }^{4}$ B.G.B., sec. 763; Cosack, B.R., p. 561.

${ }^{5}$ Gareis, H.R. sec. 65.

${ }^{6}$ Gareis, H.R., pp. 518, 519; Cosack, B.R., sec. 562.

7 B.G.B., sec. 762.

8 B.G.B., secs. 611-630. Including also remunerative agreements of man date and deposit: cf. B.G.B., sec. 675 .

? B.G.B., secs. 631-651; Cosack, B.R., sec. 143.

${ }^{10}$ Gareis, H.R., p. 394.

11 H.G.B., secs. 383-406: Gareis, H.R., sec. 51; Cosack, H.R., sec. 43.

12 H.G.B., secs. 407-415; Cosack, H.R., secs. 95, 96; Gareis, Lehrb. H.R., sec. 52 .

${ }^{13}$ H.G. B. secs. 425-452; Gareis, H.R., sec. 56.

14 Inland navigation statute June 15, 1895; Gareis, H.R., sec. 58; Cosack, $H . R$., secs. 37, 94.

is H.G.B., secs. $453-473$; Gareis, H.R., sec. 57. 
17. Brokerage ${ }^{1}$ and agency; ${ }^{2}$

18. Bailments ${ }^{3}$

19. Passenger carriage agreements $; 4$

20. Ocean carriage agreements;

21. Shipmasters' agreements; and

22. Ocean hire agreements ${ }^{c}$;

23. Mercantile power of agency (procuration) ${ }^{7}$ and

24. Mercantile employment by local custom. ${ }^{8}$

Under remunerative agreements for service may be placed:-

25. Agreements for domestic service $^{9}$ which are usually based on particular statutory provisions, and which exhibit a special class of legal relations bearing a close connection historically to family law;

26. Publishers' agreements $^{10}$ for the multiplication and circulation of works of literature and art in which an author's right may be involved.

Two mutually contiguous groups of agreements are found in agreements for insurance (or assurance), and capitalization agreements:-

27. Insurance involves ${ }^{11}$ the assumption upon payment, of risk of certain hazardis to which objects of property are liable; thus fire, hail, etc. The earliest and

I B.G.B., secs. 652-656; H.G.B., secs. 93-104; Gareis, H.R., sec. 53; Cosack, B.R., sec. 152 , and $H . R$., secs. $45,74,76$.

2 H.G.B. secs. 84-92; Gareis, H.R., sec. 54.

3 H.G. B., secs. 416-424; Gareis, H.R., sec. 55.

- On railways, see H.G.B., sec. 472; Gareis, L.ehrb. d. H.R., sec. $57 c$. On ocean passenger conveyance, see $H . G . B$., secs. 664-678; Gareis, H.R., sec. 113.

5 H.G.B., secs. 556-663: Gareis, H.R., sec. 112.

6 H.G.B., secs. 511-555; "sarine statute, Dec. 27, 1872; Gareis, H.R., sec. 111 ; Cosack, H.R., sec. 36 .

7 H.G.B., secs. 48-53 (Prokura); secs. 54-58; Gareis, H.R., sec. 22.

8 H.G.B., secs. 59-83; Gareis, H.R., sec. 21.

${ }^{9}$ Concerning the law of domestic service, see Einf.G. z. B.G.B., Art. 95.

${ }^{10}$ Cosack. H.R., sec. 83; Gareis, H.R., sec. 59.

11 Concerning the law of insurance, see Einf.G. z. B.G.B., Art. 75, also R.G., May 12, 1901; on the business of insurance see H.G.B., sec. 1, No. 3; Gareis, H. R., sec. 62 . 
most complete development of this law is seen in marine insurance. ${ }^{1}$

Capitalization agreements include:-

28. Life insurance $;^{2}$ and

29. Annuity insurance; ${ }^{3}$

30. Agreements based on credit; thus suretyship, ${ }^{4}$ accreditation, ${ }^{5}$ and running accounts with or without credit; ${ }^{6}$

31. Securities (Wertpapiere) which are executed in writing, and by giving and taking of the security papers in a so-called pure agreement, or formal contract of modern law. In its internal essence the nritten obligation (Skripturobligation) is a promise of payment which the maker of the paper undertakes in a certain manner importing obligation; and which the holder accepts in a corresponding manner. Securities ${ }^{7}$ are classitied according to the different methods by which the creditor is designated, and the obligation is created as:-

(a) [Obligations running to a particular person and requiring a special indorsement (Rektapapiere); (b) mercantile orders to pay or deliver to the order of another ${ }^{8}$ (Orderpapiere) $;^{\ominus}(c)$ bills of exchange and promissory notes $^{10}$ (Blankopapiere); and (d) instruments payable to bearer (Inhaberpapiere) ].

The most important mercantile orders are bills of exchange which in Germany are comprehensively governed by the general bills of exchange statute.

1 H.G.B., secs. 778-900; Gareis, Lehrb. d. H.R., sec 118.

2 B.G.B., sec. 330 (insurance in favor of third persons). Life insurance in general see Gareis, $H . R$., sec. 64 .

${ }^{3}$ Gaseis, H.R.; p. 729: B.G. B., secs. 759-761 (annuities); cf. also B.G.B., secs. 330, 1073, and Einf.G. z. B.G.B., Art. 96.

H.G.B., secs. 765-778; Endemann, Lehrb. d. bürgerl. R., sec. 190.

${ }^{5}$ Gareis, H.R., sec. 67.

- H.G.B., secs. 355-357; Gareis, H.R., sec. 66; (indorsement (Giroterkehr) and accounts current (KontokorrentvertraR)), Cosack, H.R., sec. 69.

${ }^{7}$ Securities in general, see Gareis, H.R., sec. 69.

8 H.G.B., secs. 363-365; Gareis, H.R., sec. 73.

- Bills of Exchange Act, Art. 12, 13, 36; Gareis, H.R., sec. 70, III, 2; id., sec. $89,3, \mathrm{pp} .601-603$.

10 B.G. B., secs. 793-808; H.G.B., sec. 367: Gareis, H.R., sec. 722. 


\section{SECTION 24}

\section{(b) OBLIGATIONS ARISING OUT OF UNLAWFUL $\operatorname{ACTS}^{1}$}

The law determines what violations of rights give rise to delictual obligations. According to positive law all intentional and negligent infringements of the private rights of others, produce duties which are directed first of all toward compensation; but which frequently, at least in the Roman law, turn on a wider accountability of punishment.

If injuries which pertain to the state considered as respublica and not as fiscus, are set aside; then we find that the objects of legal infringement in the sphere of private persons, are either (a) material, or $(b)$ immaterial legal advantages.

The former include injuries to rights of ownership and possession which are called in the Roman law furtum, rapina, and also damnum injuria (corpore corpori) datum, with actio ex lege Aquilia. ${ }^{2}$

Infringements of immaterial things include:-

1. Illegal killing, injuries to the person, or deprivation of liberty $;^{3}$

2. Injury to reputation (slander) $;^{4}$

1 B.G.B., sec. 823 , et seq.; cf. Salkowski, Inst., secs. 150-154; Endemann, op. cit., sec. 200.

2 Violations of the right of ownership lead to compensation ( $B . G B$., sec. \$23, also C:iminal Code, sec. 303); also willful injuries contra bonos mores (B.G.B., sec. 826); and accidental damage to things illegally taken (B.G.B., sec. 848).

${ }^{3}$ Criminal Code, secs. 211-241; B.G.B., sec. 842; damages for loss of earning power, and for subsistence, B.G.B., sec. 843 ; annuity damage in killing, for loss of support, and damages for funeral expenses, B.G.B., sec. 844: damages for loss of services, B.G.B., sec. 845 .

${ }^{4}$ Criminal Code, secs. $185-200 ;$ B.G. B., secs. 824,826 . 
3. Violations of rights of authors; thus infringements of literary, art or technical works;

4. Many systems of law make particular provision for certain sexual offenses such as bastardy, and illegal cohabitation, which are recognized as sources of delictual obligations, and upon which damages are based for outlays, etc., as well as for support. ${ }^{2}$

Positive systems of law answer in various ways, the question, whether and to what extent one is answerable for injuries to third persons committed by another; thus his child, his pupil, companion, or servant $;^{3}$ and also as to the extent of liability for injuries done by animals." Many systems of law make provision under certain conditions for damages arising out of injuries done by wild animals. ${ }^{5}$

1 See supra, sec. 18, IV, V.

2 B.G.B., secs. 1708-1718, also secs. 1300 , and 825 .

${ }^{3}$ Cf. Code Civil, Art. 1384, 1797; Prussian L.R., I, 11, sec. 930; the Damage Act of June 7, 1871, secs. 1, 2; (see Einf.G. z B.G.B., Art. 42): liability for injuries by employees, B.G.B., secs. 831,840 (2); liability for failure to exercise a supervision over others, as minors, etc. B.G.B., secs. 832 and $840(2)$.

1 Liability of owners of animals $B . G . B$. sec. 833 ; of keepers of animals. B.G.B., sec. 834 .

s B.G.B., sec. 835 and (Einf.G. z. B.G.B., Art. 71, 72.) 


\section{ADDENDUM TO TWO PRECEDING SECTIONS}

While agreements (sec. 23) and delicts (sec. 24) are the chief sources of obligations, yet they are not the exclusive sources. There are obligations which are similar in origin to agreements; there are some which are similar in origin to delicts; and some which are based purely on statutory provisions. ${ }^{1}$ The first class (obligationes quasi ex contractu) includes negotiorum gestio, or voluntary agency which is the counteipart of mandate $;^{2}$ communio incidens, or community of ownership not arising out of agreement, ${ }^{3}$ which is the counterpart of partnership; and the obligations of guardians.

Obligationes quasi delicto include the liability of innkeepers for property stolen, belonging to guests $;^{4}$ and the duty of making compensation arising from keeping dangerous animals. ${ }^{5}$ The duty to provide support for one's kindred is purely statutory. ${ }^{6}$ Legal obligations, or obligationes ex lege include, in addition to the duties mentioned, the duty of making compensation in expropriation, ${ }^{7}$ the duty of producing papers and other things for inspection, ${ }^{8}$ and other similar statutory duties. ${ }^{9}$

1 Salkowski, op. cit., secs. 155-157.

2 Management of business without mandate, B.G.B., secs. $677-687$.

3 B.G.B., secs. 741-758.

4 B.G.B., secs. 701-704.

${ }^{5}$ See note 4, p. 174 .

${ }^{6}$ Duty to furnish maintenance, B.G.B., secs. 1601-1615.

${ }^{7} \mathrm{As}$, also, in other surrenders of property required by statute; see Gareis, Grundriss z. D. b. R., sec. 115 , p. 124.

${ }^{8}$ Duty of production of things, B.G.B., secs. 809-811.

${ }^{9}$ For example, the statute regulating the liability of railroads for injuries (June 7,1871 ), sec. 1 , and liability according to H.G.B., sec. 453 . 


\author{
CHAPTER IV \\ PURE FAMILY LAW
}

\title{
SECTION $2 \overline{5}$
}

\section{PURE FAMILY LAW-GENERAL PART}

All family law commences with the regulation of the physical and ethical relations between man and woman. The regulation of all those relations which naturally spring from the physical and ethical tie and embrace the objects of the family, is based on these natural relations.

There are to be distinguished: (a) pure family law, or the regulation of the personal relations of the members of the family among themselves without regard to property; and (b) the law of family property, or the sum of legal principles evoked by the natural influence of personal relations on property. The law of family property legally establishes and guarantees, by means of command and prohibition, this influence and operation on the legal relations of the family in the domain of things, ${ }^{1}$ obligations and immaterial property.

All pure family law has in common that the duties comprised therein are preceded by or are in imitation of natural relations. They have more of an ethical than a juristic aspect. The content of these duties is not worked out by particular performances. The control

"["Things in the legal sense are material objects."-B.G.B., sec. 90.] 
over the person which in different degrees is the object of this law, never extends to the total dependence of the person controlled under the will of the person entitled. The person bound is always regarded as a person, that is a legal subject. The tendency of legal standards regulating pure family relations is directed to the end that the interest of the person bound, as well as the interest of the person entitled, shall be protected. Consequently all legal relations of the family are necessarily two-sided, both as to duty and interest.

Legal order cannot guarantee but can only further the objects of the family relation by protecting it against offending violations. Morals, far more than law, has to do with the security of family life and its objects. Churchly legislation or the establishment of standards on the part of religious societies which concern themselves with the regulation of family life by means of commands and prohibitions for the community life of kindred, has a connection with morals. The state, however, has its own peculiar interest in this regulation of the family; and therefore it lends the aid of its sovereign power to such commands and prohibitions, or itself establishes such rules under its own force. To this extent, these regulations are matters of public law and withdrawn from the province of private arrangement. Yet family interests are not simply of a public nature; but there reside in the participating members, interests of a private character.

The relations of pure family law are, ${ }^{1}$

1. The relation between husband and wife (marriage);

1 For a comparison of French and Anglo-American family law, see the address of Georges Barbey before the Ainerican Bar Association.-XXIV, A. B. A. Rep. (1909). p. 431.] 
178 SCIENCE OF LAW

2 . The relation between parents and children (descendants);

3. The relation among other relatives by blood and marriage;

4 Artificial family relations.

These relations are considered in the ensuing sections without regard to family property. 


\section{SECTION 26}

\section{(1) MARRIAGE}

The natural relation between husband and wife appears to have had its legal genesis in the entire subjection of the weaker to the stronger person, as a mere chattel. This was true whether this subjection was attained by force, purchase, or some other barbaric method." As long as this social condition prevailed, which was of long standing in the Orient, and so long as the husband recognized the wife simply as a slave, it was needless, it goes without saying, to speak of a law of marriage. The law of marriage first began when the family interest of the wife was legally recognized; and when this interest became legally protected as to the commencement and termination of her relation to the husband, against his arbitrary will. Such protection is even conceivable ${ }^{2}$ where the wife cannot claim

1 Concerning capture marriage and purchase marriage, see A. Heusler, Institutionen des deutschen Privatrechts, sec. 131 (Bd. I), p. 277. Concerning Mutterrecht and capture marriage. and their remnants in Germanic law and life, see Dargun (Gierke's Untersuchungen zur deutschen St.- u. R.- Geschichte, Bd. XVI.)

Concerning clan relationship, and particularly totemism, and exogamy, the historical precedent of monagamous marriage, see J. Kohler, in $K$. $u$. v. Holız. Enz., I, p. 27 and literature entered on page 30 (note).

Among the Gaberi, a heathen, Nigritic race on the Shari river, who were visited by Dr. Nachtigall who also called on the Baghirmi King, "there prevails a system of plural wives; and it is simply a question of property. A wife may be had for a horse, a half dozen fat hounds, or by similar exchange. If the wife bcars no children, she becomes a slave, and labors or is sold. If she bears five children, then she may return to her own parents, when she desires, as the purchase price in such case has been amply recovered." -Nachtigall, "Rundschau," III, 1877, Heft 6, p. 370 . Purchase marriage in the Code of Hammurabi, secs. 128, 139.

2 The legal relations between ascendants and descendants proceed in parallel lines with this development (see sec. 27); and accordingly, also, the evolution of the family or patriarchal state is historically coincident (see secs. 7, 8). 
of the husband the entire conjugal community; thus, in concubinage, ${ }^{1}$ and also where the husband is not prevented from sustaining a sexual relation to a plurality of wives at the same time (polygamia simultanea). ${ }^{2}$

It is, however, of the essence of real marriage-that is to say, marriage in the sense of modern European civilization - that the wife, as differing from the situation of the concubine-even the concubine of Roman law-sustains an honored position as the life companion of the husband. True marriage is an exclusive relation

1 Concubinage in the Roman law became, from the time of Augustus, a species of incomplete marriage. The concubine did not attain, by such union, the rank and social position of the husband. Her children were not considered legitimate, and did not comie under the pairia potestas of the father. Concubinage like marriage was a monogamous institution: eo tempore, quo quis uxorem habet. concubinam habere non potest. Concubina igitu ab wrore solo dilectu separatur. - Pauli sent recept., II, 20; Sohm, Inst., pp. 274, 275.

The position of the Roman concubine whose children were called liberi naturales was by no means always one of degradation: si modo ea sit, qua in concubinatum se dando matrone nomen non amisit ut puta qua parroni con. cubina fuit. Dig. I, 14, 48, 5. pr.

2 According to the Code of Hammurabi, marriage was already a real marriage, that is, monogamous. Only in exceptional cases, was a husband permitted to take a second wife, as when the first was chronically ill (Code, secs. 141, 148). The taking of concubines was however always allowed: and commerce of the husband with his slaves was permitted (Code, secs. 137, 144-147).

Among the Tu people (Tibesti, in Sahara) visited by Dr. Nachtigall, polygamy prevails; "yet no man is permitted to have more than one wife at the same place, although he may have a plurality of wives in different places. Therefore the Tu tradesmen have wives stationed at the various places on their routes."-Nachtigall, Sahara und Sudan (Teil I, 1879), pp. 447, 685 .

Cf. Cap. Reg. Fr. Pippini Regis Cap. Decretum quod jactum fuit ad Vermeriam palatium temporibus domini Pippini regis...VII. (De serio qui ancillam suam concubinam habuerit, et illa relicta, domini ancillam i'ult ducere.) Si servus suam ancillam concubinam habuerit, si ita placet. potest. illa dimissa. comparem suam ancillam domini sui accipere; sed melius est suam ancillam tenere. . . IX. (De muliere qua virum suum in alio pago sequi non vult.) Si quis necessitate inevitabili cogente in alium ducatum seu provinciam fugerit, aut seniorem surm, cui fidem mentiri non poterit, secutus fuerit; et uxor eius cum valet et potest, amore parentum aut rerum suarum, eum sequi noluerit, ipsa amni tempore, quamdit vir eius, quem secuta non fui. vivit, semper innupta permaneat. Nam ille vir eius qui necessitate cogente in alium locum fugit, si nunquam in suam patriam se reversurum sperat, si se abstinere non potest, aliam uxorem $\mathrm{cum}$ poenitentia potest accipere.-Mon. Ger. Hist. I.L., sect. II (ed. Alf. Boretius) tomi I pars prior, Hannovera, 1883 pp. $40,41$. 
with mutual obligation of sexual fidelity (the principle of monogamy.) Finally, this relation is one of ethical character and intended for life-long duration. To the creation of such a relation there has been requisite among all peoples, and in all ages, where this relation has been recognized, a definite form. Notwithstanding a variety of kinds of marriage differing in particulars, no deviation is distinguishable in the formal and fundamental character of the form of marriage: thus the juste nuptice juris civilis and matrimonium juris gentium of the Romans.

Marriage, therefore, is a sexual relation between husband and wife created in legal form, based on the strict principle of monogamy, and contemplating life-long duration, by which relation the husband recognizes the wife as his equal life companion.

This relation, in the consecration of which the state and society ${ }^{1}$ may have a vital interest, may be preceded by preliminary. legal acts, as the betrothal ${ }^{2}$ (sponsalia, Verlobung). It may also be preceded by a marriage contract (Ehevertrag), that is to say the agreement governing the personal or the property relations of the parties to the proposed marriage. This agreement, it is evident, can alter only leges dispositive and not the essential attributes of marriage established by lex cogens.

Marriage is canonical and civil, accordingly as the state recognizes regulations of the church with reference to the conditions, and form of celebration of marriages, or establishes its own standards. Civil marriage is either facultative, obligatory, or auxiliary. The German imperial law ${ }^{3}$ recognizes only obligatory civil mar-

${ }^{1}$ Also religious communities; cf. B.G.B., sec. 1588, Einf.G. z B.G.B., Art. 46, III.

${ }^{2}$ B.G.B., secs. $1297-1302$.

3 B.G.B., sec. 1303 . Marriage is consummated by the parties betrothed appearing personally and at the same time before a registrar and declaring their intention to marry each other: B.G.B., sec. 1317 . 
riage. It regulates its form and authentication, the requirements of its celebration, the grounds on which it may be declared invalid or be annulled, ${ }^{2}$ as well as the grounds upon which it may be dissolved, or the conjugal community (eheliche Gemeinschaft) may be furthered without dissolving the marriage. ${ }^{2}$ It is evident that the imperial law would not interfere with canonical duties with regard to marriage. The civil code, however, expressly excludes such interference. ${ }^{3}$

The legal effects of marriage apart from matrimonial régime (eheliches Güterrecht) are $(a)$ the creation of a conjugal community, ${ }^{5}$ consequently the legal claim of the wife to use the family name of the husband, ${ }^{6}$ the claim of the wife to rank, position, title, ${ }^{7}$ civil rights, domestic rights and maintenance; $(b)$ the obligation of both spouses to marital fidelity ${ }^{8}$ and $(c)$ the matrimonial dominion of the husband as the head of the family, in household affairs, in the selection of the domicile, and in authority to consent to, or set aside, certain legal acts of the wife. ${ }^{9}$

1 B.G. B., secs. 1323-1347, 1350.

B.G.B., secs. 1564-1587.

3 B.G.B., sec. 1588 .

- ["A collective description of the effect of a marriage on the property owned by each of the spouses at the date of the marriage. or acquired at a subsequent time."-Schuster.] See sec. 31, infra.

- [Conjugal community (Lebensgemeinschaft) "includes not only physical cohabitation but also a joint participation in all the affairs of life (consortium omnis vita)."-Schuster.] See B.G.B., sec. 1353.

B.G. B., sec. 1355.

7 Except in misalliance and the so-called left-hand, or morganatic marriage.

8 The obligation of the husband to marital fidelity is in accordance with the ethical conception of the marriage relation in Christian civilization. It also comports with the purpose that the law of marriage shall equally guarantee and protect the vital interests of each of the spouses in the conjugal community. B.G.B., sec. 1565 [divorce for adultery].

- B.G.B., secs. 1354, 1358, 1924. 


\section{SECTION 27}

\section{(2) THE RELATION BETWEEN PARENTS AND CHIL- DREN}

From the sexual relation (sec. 26) there springs up in accordance with nature, the relation of descendants. The relation between parents and children has undergone historically the same evolution as the relation between man and wife. So long as the wife was only the slave of the husband, so long also was the child completely subject to the will of the master of the wife. The ethical and legal elevation and regulation of the position of the wife ${ }^{1}$ also elevated the relation between the father and the child. What was primitively only an interest of the father in his child considered as a thing, became after a time a personal, protected interest of the father worked out through long stages in the progress of civilization. This interest of the father in

\footnotetext{
1 The natural relation between mother and child is also legally standardized from the moment that the mother becomes capable of legal rights. From that moment, likewise, there exists one of the various phases of a thoroughgoing Mutterrecht which had a peculiar operation in the domain of primitive Germanic law of inheritance and extended into historical times.

"The dominion of Muterrecht arose out of conditions where seal marriage was not yet known; at any rate, not marriage as a binding tie of relationship, and therefore not as the basis of kindred association. Mutterrecht may have continued even when the existence of marriage became unquestionable; inasmuch as the notion of marriage as an indissoluble bond between man and wife was present even where the blood relation between parent and child was a fact of no consequence. In this stage of development children did not belong to the clan of the father. The clan was formed only of children who sprang from the same womb. . . The exclusive dominion of Mutterrecht was broken among the Germans long before the migration of the peoples, and certainly by the circumstance that the people betook themselves to agriculture and became settled. This was true even when agricultural land was subject to periodical distribution. The domestic impulse aided to regenerate the blood relation between father and children."-A. Heusler, Institutionen des deutschen Privatrechts, Bd. II, p. 523, in connection with Dargun (sec. 26, note 1, supra).
} 
the being and action of the child coincides with the interest of the earliest community, the family, at the head of which stood the house-father.

State power was preceded by family power-the strict form of family jurisdiction with jus vite ac necis of the head of the family over his dependents. The type of this strict family relation is the Roman patria potestas. Germanic law took a different viewpoint. It is the natural necessity for protection of the child, which is legally regarded, and on account of which, the child is placed under the protective power (mundium) of the father. Modern German paternal power is based on the interest of the child and not that of the father.

Modern law is in accord with the latter view. The child requires, so long as it is young, ${ }^{1}$ protection and education. From these ethical, physical and social interests, corresponding rights and duties of parents with reference to children, arise. The various legal provisions regarding moral and religious training of children, and in particular the duty of obedience on the part of children are based on these interests.

Under the influence of Roman law, the parental power of the father took on a special development.2 The German imperial law provides for parental power which generally is exercised by the father, ${ }^{3}$ and in exceptional cases by the mother. This power involves the right and duty to care for the person and the property of the child. Parental power belongs to the mother, when the father forfeits his right by the commission of a criminal offense; ${ }^{4}$ when the marriage is dissolved; or

1 B.G.B., sec. 1626. The child while a minor remains under parental power. Also according to the ancient Greek law, parental power terminated with the majority of the child which began as a rule with the age of 18 . See Lipsius, op. cit.

2 Sohm, Inst., sec. 87.

${ }^{3}$ B.G.B., sec. 1627.

- B.G.B., sec. 1680. 
when the father dies or is declared legally dead. ${ }^{1}$ Parental power arises through birth in lawful wedlock; ${ }^{2}$ legitimation whether by subsequent marriage, ${ }^{3}$ or order of public authority: ${ }^{4}$ and through adoption..$^{5}$ The father of illegitimace children has no patria potestas over them; and illegitimate children stand in the same relation to the mother as legitimate children. ${ }^{6}$

1 B.G.B., sec. 1684 .

2 B.G.B., sec. 1591 .

3 B.G.B., sec. 1719.

B.G.B., sec. 1723.

5 B.G.B., sec. 1741.

'Legal position of illegitimate children, see B.G.B., sec. 1705, and Geo. Hörle, under this title (Emil Roth, Giessen, 1900). 


\section{SECTION 28}

\section{(3) OTHER BLOOD RELATIONS AND RELATIONSHIP BY MARRIAGE}

Social conditions generate interests in connections with other relatives than those standing in the limited circle of parents and children: thus, with reference to grand-parents, brothers and sisters, uncles and aunts, and nieces and nephews. The less developed the state, the stronger is the family sense, and the necessity for cohesion of those related by ties of blood. ${ }^{1}$ It is for this reason that kindred relationship is of such great significance in ancient German law. The legal operation of relationship dininishes as relationship itself lessens. There is, therefore, a determinate measure, differing in different systems of $1 \mathrm{aw},{ }^{2}$ for the computation of degrees of relationship of blood as well as of affinity.

Relationship has its chief importance in the German law, in that interests of relatives are protected as legal interests in juridical and extra-juridical controversies.

The legal influence of relationship in modern law is shown, apart from property rights, in co-operation in the education of children, in prohibitions of marriage, and also as a qualifying element in criminal law, all under definite regulatory provisions.

1 Sec. 7, II, supra, and sec. 8, II, 2, supra.

${ }^{2}$ B.G.B., sec. 1589 ; on the Roman computation of degrees of kindred, see Sohm, Inst., sec. 78; the Germanic computation, see Heusler, Inst., sec. 186, and literature there noted; canonical computation, see J. Fr. v. Schulte, Lehrb. d. kathol. u. evangel. Kirchenrechts (4th ed., 1886), sec. 167. 


\section{SECTION 29}

\section{(4) ARTIFICIAL RELATIONSHIP'}

The interest of favoring the protection of relatives extends so far, that, according to many legal systems, in default of natural relatives, other persons are regarded as artificial, or juridical, or according to the canonical conception, as spiritual relatives, and brought within the protective care of the law. This substitution of relatives is of three classes: (1) the natural protective direction of the head of the family may be supplied to a certain extent, as is the case in the legal institution of guardianship; (2) children lacking parental care may receive it by adoption; ${ }^{2}$ and the interest in having an heir, when nature has denied a natural heir, may occasion the creation of such an artificial relationship; (3) the lack of a brother was supplied according to ancient law,. in the institution of blood fraternity, especially among the Germans. ${ }^{3}$

${ }^{1}$ Sohm, Inst., sec. 90; Frensdorff-Kraut, op. cit., sec. 191. Concerning artificial family relationship among the red Indians, see J. Kohler in $K . u$. . Holtz., I, p. 35.

${ }^{2}$ B.G.B., sec. 1741, et seq.; compare Dr. Adolf Hecker, Die Adoption im geltenden Recht als product der historischen Entwickelung (Leipzig, 1903. Gustav Fock.)

${ }^{3}$ [ Blutsbruderschaft, an ancient ceremonial agreement between men involving mutual promises of fidelity and protection, and revenge against injuries from others. This agreement was concluded with a formality of blood letting, in which the blood of the parties was made to run together, or by drinking of a mixture of this blood with wine.] Concerning Affatomie [a Germanic procedure of adoption, which was sometimes employed for the transfer of property; see Ross, op. cit., p. 70, et seq.] ; see also Heusler, Inst., sec. 194. See Kohler, in K. u. v. Holtz, I, p. 35 regarding the institution of blood fraternity and blood sisterhood (Blutsschwesterschaft) the former of which developed among the Malays and East Africans into an artificial personal unity with community of wives.

With reference to adoption among the ancient Greeks, see law of Gortyn (Ed. Gmoll) (supra, sec. 15, p. 106, note 5,) X, 33. Adoption played a prominent part in Babylonian law; see Code of Hammurabi, secs. 185-193. As to the so-called Sumerian family laws, see Kohler u. Pieser, op. cit., p. 133. 
The most important of these relations, however, is that of guardianship (cura or tutela according to the Roman law). Guardianship is a public institution (munus publicum) providing a definite providential and supervising legal protection over the ward, always under direct control, or even co-operation of a public organ,a guardianship court (Vormundschaftsgericht), a curator, or a communal orphan council (Oberiormundschaftsbehorden). Guardianship is instituted for such persons as are not able to manage their own affairs on account of sex (thus, guardianship over females) $;^{1}$ on account of minority $;^{2}$ chronic mental incapacity $;^{3}$ or on account of absence." According to present German law, the most conspicuous form of guardianship, the substitution of a guardian in property matters, is as a rule unnecessary so long as the mother of the ward is alive. ${ }^{5}$

\footnotetext{
1 Women were under guardianship during their entire life among the Greeks (Lipsius, op. cit.); also among the Germans in the Middle Ages; see Heusler, Inst., sec. 171. In modern law female guardianship is everywhere obsolete. In the German law women are declared competent to become guardians.

2 B.G.B., sec. 1773.

3 B.G.B., sec. 1896; here belongs, also, the care of prodigals and dipsomaniacs: $B . G . B .$, secs. $6,1141896$.

B.G.B., sec. 1911 (curatorship).

B B.G.B., secs. 1684-1698 (parental power of the mother.)
} 
CHAPTER V

FAMILY PROPERTY

\section{SECTION 30}

\section{FAMILY PROPERTY IN GENERAL}

Those interests which are legally protected under the name, "pure family rights," have collectively, to a greater or less extent, a prominent connection with property,the satisfaction of necessities appertaining to things. This arises not on account of property as such, but on account of the purely personal connections recognized and protected by law. This connection is foremost a pure condition of fact based on an actual relation. This relation is elevated by law to the plane of a legal relation, but not always in a uniform manner. Different peoples in different ages have given recognition to the proprietary operation of family relations, to the extent that the ethical conception of family relations (see sec. 25) has governed. A great diversity of economic and political interests have also had a concurrent influence on the form of the law. ${ }^{1}$

The degree, also, in which individual relations of family life, considered as legal relations, have been recognized as legally operative on property, has been highly diverse. The connection of these relations to

\footnotetext{
1 This suggests, by way of cxample, the effect on the form of the matrimonial régime in Germany, of the founding of cities and the rise of commerce and industry; and the effect of military service of the Roman legionaire, on the form of the law of peculium.
} 
property has been, in some cases, regulated and protected by law in an obvious and prominent manner, and in other cases only in a subsidiary manner or only under definite limitations. ${ }^{1}$

Entire elimination of all proprietary interest would negative any relation of family law. Therefore, the actual influence of these relations on property requires standards. The conjugal community costs or brings money, or costs and brings money. ${ }^{2}$ The same is true of the bringing-up of children. Income of money is chiefly involved in the ancient Roman law, or where the father has the right to sell his children.

Kindred relationship also has a great legal significance from the proprietary standpoint. This was shown in the practical proof adverted to (sec. 28 ) of mutual protection among relatives. It is further exhibited in provisions for guardianship administration of property, as where relatives act as guardians or as members of family councils exercising guardianship powers. The chief importance, however, of the proprietary aspect of the legal relations of relatives, lies in the law of inheritance. Relatives in many systems of law, as in the German law, are the natural heirs of the property of deceased persons (see sec. 35).

Guardianship (cura, tutela, mundiburdium) is an artificial family relation which, in the most conspicuous manner, has a legal connection with property. The guardian is the protecting master of the person of the ward, and he is also the administrative manager of his property.

Where a pure family relation legally imparts a definite operation on property, in such case the family relation,

\footnotetext{
1 Thus, guardianship which may be limited to the mere administration of property alieno nomine.

${ }^{2}$ Das eheliche Zusammenleben kostet oder bringt geld oder kostet und bringt Geld.
} 
or its accual consequence, is itself treated as a juristic fact, and the law annexes a determinate legal effect on its appearance. Thus, on the celebration of marriage, or sometimes only after its consummation, or after the birth of a child, there commences a definite matrimonial régime. On the appointment of a guardian, there arises a guardianship administration, etc. The objects of such administration of the interests of the matrimonial régime are not simply material and immaterial things (secs. 17 to 21 ), but also obligations (sec. 22). In other words, they are rights which may be affected by the family relation, which are:-

Rights of ownership (sec. 20);

Jura in re aliena (sec. 21);

Rights in immaterial things (sec. 18); and

Obligation rights ${ }^{1}$ (sec. 22).

Righis of family property, therefore, involve at the same time real and personal relations ( $c$. sec. 16). Accordingly the classificatory division, "mixed law of persons and things," presents itself, which is also applicable to the law of inheritance. The latter also involves the law of obligations (sec. 34) concurrently with the law of material and immaterial things.

The legal effect of the matrimonial relation and the relation of parents and children with reference to property is discussed in the following sections $(31,32)$.

\footnotetext{
1 For example, in some systems of law, claims in favor of the wife become claims of the husband on the celebration of marriage. Sometimes marriage involves liability of the wife for the ante-nuptial debts of the husband. According to a legal paroemy: take the man, take the debt. See however the present German law (B.G.B., secs. 1411, 1415) according to which it may be said: take the wife, take the debt.
} 


\section{SECTION 31}

\section{(1) THE MATRIMONIAL REGIME (Das eheliche Güterrecht)}

The interest which a spouse has in the property of the other, is legally recognized and protected only in part and in a subordinate degree. Marriage ought not to exist for the sake of property, and, as said in Roman law, conjugal ties should nct be used for the despoliation of the spouses. A mutual interest appertains to the spouses, and, to a certain extent, there exists also a public interest, in a legal influence of marriage on the property of the spouses.

The aggregate of legal standards by which the influence of the creation, continuance, and termination of marriage, with reference to property, is legally established and limited, and accordingly by which private and public interests in the regulation of the proprietary relations existing between spouses, are legally guaranteed is called the "matrimonial réginie." This matrimonial régime is distinguished respectively as statutory and contractual accordingly as this regulation is directly and explicitly created by law (that is by statute, or custom), or is governed by agreement within the limits permitted by law.

A survey of the large variety of dissimilar institutions regulating the matrimonial régime requires a consideration of the ideas following:-

(a) It may be said that marriage is a personal relation and not a proprietary relation; that marriage should in general have no influence whatever on property; that marriage may by a special legal act, the creation of an 
agreement, effect a proprietary relation, and that in the absence of such a legal act, marriage has no legal influence on the property of the spouses. This is the standpoint of Roman law, according to which, the marriage of a poor man and a rich lady would leave the husband during and after the marriage as poor as before the marriage, and contrariwise.

A special proprietary relation is possible by the arrangement of a dowry (dos, Mitgift). Dowry is a proprietary complex, intended ad onera matrimonii sublevanda. It is under the control of the husband during marriage, and on the termination of the marriage, is as a rule to be restored, in corpus to the wife, her heirs, or the giver of the dos. The ideas governing the influence of marriage on property which have prevailed among Germanic peoples from the remotest times, depart radically from this system. Therefore, this sysiem has received only an insignificant place, and found only a modified application, in Germany.

(b) On the other hand, it may be asserted, that even if marriage is not a proprietary relation, or is not such in its principal aspects, that yet its actual influence on property is unavoidable; and that as the husband is the head of the family, therefore, it is fit that this actual influence should legally lie in his power. It is said that legal recognition and protection of the husband's interest in the proprietary side and consequence of conjugal life are especially suggested and are in part necessary in all those stages of civilization where the wife enjoys no capacity for legal acts or has only limited capacity for such acts; and also where her capacity for legal acts is restricted by statutory tutelage (Geschlechtsvormundschaft).

Where wife-capture, or wife-purchase is the basis of marriage, it is evident that the husband is the master of all conjugal property. Even where the wife enjoys 
respect in her ethical freedom, and is recognized as a legal subject, the husband has control of the entire conjugal property whether derived from him, from the wife, or later acquired by either of them, if the wife is legally restricted in her capacity for acts in the law.

A proprietary system developed from this situation in higher phases of civilization. In this system the husband had control of the entire property of both spouses, excepting only privileged property (Sondergut) of the wife, so long as the marriage subsisted. This dominion of the husband, with reference to property brought into the union by the wife, extended, however, only to a right of usufruct and power of administration. It was limited by the duration of the marriage, and accompanied by a duty on the part of the husband, binding on his heirs, to restore such property, on the termination of the marriage to the wife or her heirs.

'This system has received different names thus, "system of matrimonial administrative participation" (Richard Schröder); "community property" (Runde and Beseler); and "proprietary unity" (Gerber). This is the system of the ancient Saxon law (law of Eastphalia), of the Saxon Spiegel, the ancient Saxon cities, the original cantons of the Helvetian league, the ancient cantons of Berne, Zurich, etc. It was re-established in the Prussian Iandrecht; in the civil code of the kingdom of Saxony; and in the civil code of the German Empire. ${ }^{1}$ In the last

1 This code establishes the standards of the so-called administrative community system (Verwaltungsgemeinschaft) or marital usufruct as a "statutory régime" (B.G.B., secs. 1363-1425). There are also instances provided for, in which there is legally a separation of goods (Gütertrennung); and in which management and usufruct do not exist on the part of the husband as to the property of the wife (B.G.B., secs. 1364. 1426-1431).

Alongside of the statutory régime, there exists a contractual régime by which the spouses may regulate their proprietary relatiuns by agreement (B.G.B., secs. 1432-1557). Yet, important modifications of the statutory régime by agreement, require for their efficacy, as against third persons. special notice to them, or entry in the marriage property register (B.G.B., secs. 1425, 1558-1563). 
code it is provided, that unless there is a contrary provision in the marriage contract, ${ }^{1}$ the husband shall have the management and usufruct of the non-privileged property (eingebrachtes $G u t$ ) of the wife. There is excepted, the so-called privileged property ${ }^{2}$ (Vorbehaltsgut) of the wife; such for illustration as is acquired through the labor of the wife, or her independent operation in a business pursuit. To such property the control and usufruct of the husband do not extend. On the termination of marriage, the husband is required to relinquish the non-privileged property and give an account of his administration. ${ }^{3}$

(c) Finally, it may be asserted, that marriage is intended for conjugal community, and if its object is not in the first degree the common ownership of property, yet community of property is not excluded; inasmuch as the community life of the spouses, to a certain extent at least, requires common necessities in the house and home and a common acquisition of property through industry and frugality. Thus, through the combination of the property of the husband and the wife, by postnuptial arrangement, arises the first practical realization of community property-a system, or rather a

1 The marriage contract may be much simplified by reference to the hypothetical contractual régimes provided for in the civil code: (1) general community of goods (secs. 1437-1518); (2) community of income and profits (secs. 1519-1548); (3) community of movables (secs. 1549-1557); and (4) separation of goods, secs. 1426-1431, 1436), the latter of which may result also in certain cases provided by statute (secs. 1364, 1426, 1418-1420, 1425) as a "statutory régime" to take the place of the husband's management and usufruct.

2 B.G.B., secs. 1365-1371.

3 B.G.B., sec. 1421. The ancient Babylonian law regulated the matrimonial régime in a manner similar in its chief aspects, to the German Civil Code; see Code of Hammurabi, secs. 162-174. The obligation of the spouses for debts, however, is different in the Babylonian law. The wife was responsible jointly with the husband for all debts of the husband contracted during marriage, and even for all ante-nuptial debts of the husband, unless such liability was expressly excluded by marriage contract. The wife could even be sold for the debts of the husband; Hammurabi, secs. 151, 152. 
variety of systems, as ancient in their origin as the Saxon law of Germany. ${ }^{1}$ It is peculiar to this institution that such property remains community property of both spouses during marriage, and on the termination of marriage, is divided or inherited without regard to its origin of acquisition. ${ }^{2}$ This property mass, the common property of the spouses during marriage, may include either all the property of the spouses and be therefore a general community of goods (allgemeine Gütergemeinschaft); or it may include only a certain part of such property, in which case it is known as particular community of goods (partikuläre Gütergemeinschaft).

General community of goods had its origin chiefly in Frankish, Westphalian and Swabian law. ${ }^{3}$ Particular community of goods is either a community of movables and of income and profits (Mobiliar-und Errun:genschaftsgemeinschaft), as in the French code and in others using it as a basis, or closely connected with it; 4 or it may be only a community of income and profits ${ }^{5}$ (Errungenschaftsgemeinschaft) wherein the property of both spouses remains normally separated even though under the control of the husband during marriage. Community of income and profits was recognized as a statutory matrimonial system of property in the Landrecht of Bavaria, $\mathrm{W}$ ürteniberg and $\mathrm{Hesse}^{\circ}$ and else-

1 Compare Richard Schrōder, Geschichte des ehelichen Güterrechts in Deutschland, 1863-1874, Part II, 2, p. 1, et seq.; Part II, 3, pp. 43, 295. This wosk is suitable above all others for the whole doctrine of matrimonial property. For the other literature, see Gareis, Grundriss, sec. 116, note 1, sec. 117, note 2. See also Heusler, Inst. sec. 136.

${ }^{2}$ According to the German Civil Code a system of community of goods can exist only by contractual arrangement of the spouses in the manner pointed out on p. 194, note 1 , and p. 195, note 1 .

${ }^{3}$ Cf. B.G.B., secs. 1437-1518.

CF. B.G.B., secs. 1549-1557.

${ }^{5}$ Cf. B.G.B., secs. 1519-1548.

'Gareis, Die Errungenschaftsgemeinschaft nach hessischen Sonderrechten (1885, Ludwigspregramm). 
where; but not of course, without variations in their provisions for marital control and usufruct.

Which of different systems of matrimonial property, applicable to a concrete marriage, is authoritative, is determined within the limits of the law either by the matrimonial contract of the spouses, or according to the law of the place where the marriage has its first domicile, that is the law of the domicile of the husband directly after the consummation of the marriage. German law provides that the matrimonial régime shall be regulated by German law, if the husband at the time of the consummation of the marriage was a German citizen. ${ }^{1}$

If the husband, after the consummation of the marriage, acquires German citizenship, or if spouses of foreign citizenship have their residence in Germany, the inatrimonial régime is governed by the law of the state of which the husband was a subject at the conclusion of the nuarriage. The spouses may, however, enter into marriage even though not allowable according to the - law of that state. ${ }^{2}$

\footnotetext{
I See notes, pages 194-195, supra, for statutory provisions.
}

2 Einf.G. z. B.G.B., Art. 15. 


\section{SECTION 32}

\section{(2) PROPERTY OF CHILDREN}

The proprietary influence which arises out of the personal and natural relation between parents and their children, depends, as is evident, primarily and chiefly on the legal form of this personal relation itself. If the child be regarded merely as a species of property of the father or the parents, there can be no proprietary right in the child. In higher phases of civilization, a recognition of such rights as belonging to children is indispensable.

The child, with the first breath of life, is legally recognized as capable of having its own interests. This recognition first of all imposes an obligatory duty on both parents (primarily and chiefly on the legitimate father, and secondarily on the mother whether of legitimate or illegitimate children) to provide for the physical support and mental training of the child. The expenditure of money in alimentation of the child is the correlate of the right of education in the parents. The duty of providing maintenance is also the recognition in law of an ethical duty which is mutual in operation. Indigent parents, grandparents, etc., must be supported by the descendants who are financially able. Associated in many systems of law with the duty of parents of providing maintenance, is the duty of providing the marriageable daughter with a marriage portion (Heiratsgut) or outfit (Ausstener).

The greatest proprietary influence, however, of parents' and children's rights is seen in the domain of the law of inheritance. Ascendants and descendants are mutually natural heirs (sec. 35 , infra). 
Parental power is brought prominently forward in the general personal relation of parents and children as a particular and distinctive form of this relation. Parental power is distinctive also in a proprietary sense. Variations in the conception of the personal relation produce, as a matter of course, differences of proprietary operation.

The law of peculium corresponded in ancient Roman law to patria potestas. Peculium was originally a proprietary complex which the father permitted the son to manage more or less independently. Another form of peculium, peculium castrense (compensation for army service) was emancipated from paternal authority. The filusfamilias therefore ceased to the same extent to be the industrial instrument of the father.

While the Roman law of peculium did not gain complete reception in Germany, ${ }^{1}$ there came into use a paternal and even parental right of management of property of the child by which a power over the child's property was exercised until majority. As to privileged property of the child parental power did not embrace any right of usufruct. ${ }^{2}$ As to non-privileged property ${ }^{3}$ of the child there was a right of usufruct in the father, and in certain cases in the mother.

\footnotetext{
${ }^{1}$ Stobbe, Deutsches Privatrecht, sec. 254, Bd. III, pp. 343, 345: for the literature see Gareis, Grundriss, sec. 134, note 1.

${ }^{2}$ Cf. B.G.B., secs. $1650,1651$.

3 B.G.B., sec. 1649 . Concerning the parental power of the mother, see B.G.B., sec. 1684; and with regard to the legal position of illegitimate children, see B.G.B., sec. 1705.
} 


\section{SECTION 33}

\section{(3) GUARDIANSHIP ADMINISTRATION OF PROPERTY}

As already observed above, among artificial relationships, guardianship in modern law has had a development peculiar to itself in the administration of property. The law distinguishes guardianship over minors ${ }^{1}$ (Minderjährige); guardianship over interdicted adults ${ }^{2}$ (entmündigte Volljährige); and curatorship over persons who apart from those cases which occasion guardianship, require a particular care and representation in their proprietary concerns, ${ }^{3}$ in consequence of mental or physical infirmity.

All guardianships and curatorships are under the direction and supervision of the state. This management is exercised usually through courts known as guardianship courts ${ }^{4}$ whose activities may be regarded as a part of non-contentious jurisdiction. ${ }^{5}$ Guardianship courts have the appointment of guardians, also in cases of necessity the appointment of a supervising guardian, ${ }^{\circ}$ the reception of guardianship accounts, ${ }^{7}$ and approval of all those acts of the guardian which are of special importance in the property concerns of the ward. ${ }^{8}$ The civil code furthermore prescribes the principles of guardianship administration, and in particular, for the safe investment of the ward's property. ${ }^{\circ}$

1 B.G.B., sec. 1773.

2 B.G.B., sec. 1896.

3 B.G. B., secs. $1909-1921$.

B.G.B., secs. $1774,1775,1787-1791,1796,1837$.

${ }^{5}$ See infra, sec. 48 , III; sec. 49 , II, 2.

B.G.B., secs. $1792,1799,1813$.

${ }^{7}$ B.G.B., sec. 1840 .

${ }^{8}$ B.G.B., sec. 1821.

' B.G. B., secs. $1807,1808$. 
Upon termination of a guardianship, the guardian is required to give account of his administration, and deliver up the estate. The guardian may be under the control of a supervising guardian (Gegenvormund). For the assistance of the guardianship court, a family council (Familienrat) may be appointed.

Guardianship over minors ends as a matter of course on the attainment of majority; that is the completion of the age 21 years. It ceases in the case of adults when the disability ends.

According to the German Civil Code, an adult may be interdicted or restricted in his disposing capacity, on account of insanity, feeble-mind, prodigality, and dipsomania. ${ }^{1}$

1 B.G.B., secs. 6, 104, 105. 114, 1896. 


\section{CHAPTER VI}

\section{INHERIT ANCE}

\section{SECTION 34}

\section{INHERITANCE IN GENERAL'}

The law of inheritance is the aggregate of legal rules by which an answer is given to the question: What legal influence has the death of a physical person upon the legal spheres controlled by him in life ? ${ }^{2}$

The first consequence of death, and a simple answer to this question which cannot be annulled by any system of law, is that a dead person has ceased to have rights. Only the living have rights. ${ }^{3}$ The dead no longer have any interests of life and therefore no longer require legal protection with reference to their external relations to persons and the community.

It might follow from this, that the property of the dead would be ownerless or res mullius; that their jura in re aliena would be without a subject and therefore void; that their rights of personality would be without interests and no longer capable of use; that what they owe could not be performed; that what is owing to them could no longer be paid as their interests have ceased; and that they could no longer exercise parental power as their marriage relations have ended.

${ }^{1}$ Cf. Sohm, Inst., sec. 95; Salkowski, Inst., sec. 173; Dahn, D. Rechtsbuck, p. 240. With reference to legal rights in human corpses see Gareis, supru, sec. 18 , page 126 , note 7 .

${ }^{2}$ Cf. supra, sec. $16 a$.

3 The effects of actual death may to a certain extent be accomplished by presumed death. B.G.B., secs. 13-20. 
These are certainly the legal negations consequent to death. But they do not proceed so far as to make negation of reality. Above all, the legal facts of family life still remain-that the father has procreated the child, and that the mother has borne it-even though death has intervened. The family remains. The family tie is not extinguished even by death. This idea proceeds to the extent that even the re-marriage of a widowed spouse may be regarded as illegal.

The prohibition of bigamia successiva, the pance secundarum nuptiarum, the burning of widows, and also in a certain sense the ancient Judaic obligatory marriage of the brother of a deceased married person, suggest the notion of continuance of family life.

Connected with these ideas operating in the domain of law, which are essentially supported by religious notions, are the primitive views of family ownership. According to these notions the property which belonged to the dead person in his life remained in the family after his death and passed by law to the nearest relatives by whom it was inherited. Thus, in the German law, the most important kind of ownership (that of land which is inherited and re-inherited) is called the inheritance. In ancient German law the notion is encountered that the inheritance passes to the heir of the dead person, and comes into the possession of the heir as if the dead person himself directly had delivered it without any action of the successor-the dead transmit to the living, le mort saisit le vif.

Landed property, therefore, does not become ownerless on the death of its former owner, but passes to the relatives. "It remains in the family" (Es bleibt in der Familie). If relatives fail, then the yet more ancient primary institution of community ownership appears. Ownerless land falls back to the community or its head. 
Ancient law, however, had already provided that, in place of actual or natural relatives, artificial relatives might step in. Provision was made for persons whose relationship might be artificially effected and simulated by a legal act in the presence of the community or its representatives: thus in German law, by adoptio in hereditatem, and in Roman law by means of testamentary witnesses considered as representatives of the Roman people. This artificial creation of heirs by means of a legal act, became of greater significance and importance the more as land ownership ceased to be the chief or even the only kind of property, and the more as monetary and credit activities developed alongside of agricultural pursuits. Credit pursuits were utterly impossible if death might annul obligations of payment; and if the creditor's claim was subject to dissolution with the person of the creditor.

It has thus come about among all peoples who have attained the level of transacting business on a credit basis, that the proprietary concerns of the dead survive them in legal form. They remain as legally protected interests. Only the persons in interest change. It results, therefore, that the legal negations adverted to do not happen. Rights as well as duties of the dead pass to their legal successors. A substitution in interest arises, to the extent that these rights and duties do not involve the departed personality of the dead. Such substitution of interest does not take place as to purely personal legal claims, or delictual obligations which do not exist as pure equivalents of property but which belong to the province of penal obligations.

In the progress of civilization, and at the latest commencing with credit pursuits, legal systems accordingly have recognized and guaranteed the interest of succession of property in the actual and designated 
relatives of the dead, or in artificial relatives-heredes extranei.

In a recognition of the interest of succession, legal systems proceed from a variety of standpoints. Sometimes it is the recognition of family interest, or the afier-effects of family ownership. Sometimes it is the consequence of the social interest directed to the maintenance of legal order which opposes strife attendant on ownerless property. It may proceed with the view of security of credit in commercial matters notwithstanding the death of the creditor and the debtor. Finally the purpose may be a furtherance of industry as well as the sense of thrift in all members of the community.

In the realization of these purposes, lies the cultural importance of the law of inheritance. On the socialistic side (in an effort to further or essentially restrict the law of inheritance) lies the danger of imperiling the advance in civilization attained by means of the law of inheritance. It is not to be asserted, however, that legislative restrictions cannot and should not govern natural succession of relatives, or succession by will; the former according to degree, and the latter according to amount.

Restrictions in the law of inheritance may appropriately be made by means of inheritance taxes which establish the interest of the community in relation to or comparison with the interest of succession; and allow the interest of society to prevail in those cases in which legislation regards the interest of succession (as in the case of an extraneous successor) as no longer desirable of complete protection.

The interest of succession may be based:-

(a) On succession tọ particular things, ownership of particular rights, or the burden of particular debts. 
In other words inheritance may follow only certain interests protected before death, and presently protected in favor of the legal successors of the dead; or

(b) Succession may be based on the totality of interests of the dead (excluding purely personal interests). In this case the successor assumes the entire legal sphere of the dead person as it exists at death, as a single comprehensive interest.

The first interest $(a)$ corresponds to singular succession (successio in singulas res, particular succession, Sondernachfolge). This species of succession may also arise among living persons, as in the case of assignment or cession (sec. 22, supra), and also tradition (sec. 20, V., 2, supra).

Succession in the second sense $(b)$ is the interest in universal succession (successio per universum jus defuncti, Gesamtnachfolge). According to the common law of Germany, an example of universal succession, and the only one, is hereditas ${ }^{1}$-the inheritance of the entire property of a dead person, including his liabilities. The heir (heres) succeeds completely to the legal spheres vacated by death, excluding only the rights and duties flowing from the personality of the defunctus. He continues to the same extent as the dead person, to bear his interests; and becomes accordingly the owner of the objects of these interests. He becomes the creditor of the claims of the dead, and the debtor of his obligations. According to Roman law, this result did not as a rule at once follow, if the inheritance was deferred (by a tender or offer on one of the grounds of

1 Dig. I 37, 29, 2 (de acq. v. om. hered.): Heres in omne jus mortui, non tam singularum rerum dominium succedit, quum et ea, qua in nominibus sunt, ad heredem transeant. Dig. I, 62, 50, 17 (de reg. jur.) (Julian): Hereditas nihil aliud est, quam successio in universum ius, quod defunctus habuerit. To the same effect is the German Civil Code which provides that the property (the inheritance) of a dead person shall go as a whole to one or more persons (heirs). B.G.B., sec. 1922 . 
delation (delatio) ); but resulted only when the inheritance (hereditas deleta) was acquired after delation by an act of entry (aditio). According to German and French law succession follows delation of the inheritance without aditio."

Based on the difference of the grounds of delation there are distinguished: natural, and testamentary succession (secs. 35, 36).

In order that property of dead persons may be administered in accordance with law and an allowable delation, the security of claims on the part of heirs, ${ }^{2}$ is not only provided for by civil procedure but also protected by the administrative interposition of the state, through courts of probate ${ }^{3}$ as a part of its noncontentious jurisdiction (infra, sec. 49).

1 It is possible in modern law, as it was in ancient law, to reject a proferred inheritance (repudiatio, beneficium abstinendi). Limited succession [restricting liability] was also possible by means of the institution of beneficium inventarii.

According to the German Civil Code (scc. 1942) the inheritance vests on death without entry, without prejudice to the rights of the heirs to renounce. The heir may not, however, repudiate the inheritance when the period fixed by law has elapsed (usually six weeks) or after he has expressly accepted the inheritance.

2 B.G. B., sec. 2018.

3 B.G.B., secs. $1945,1960$. 


\section{SECTION 35}

\section{NATURAL SLCCESSION:}

The legal recognition of the interest of the members of the family in the descent of property of dead persons leads to natural succession, so called. Succession by relatives is natural succession or succession by the will of nature.

In the German law, such succession results ipso jure without any act of the heirs. Ancient German law recognized only succession by relatives, ${ }^{2}$ and not succession by testament. Natural succession was permitted to have effect only so far as relationship existed; remote relatives for the time, being excluded in favor of near relatives. If relatives failed, the estate passed to the greater and lesser communities of which the dead person was a member; or passed to the head of these communities. Roman law, in like manner, permitted succession by relatives, but only in default of testamentary disposition-si intestatus descesserit defunctus. In the latter case the relatives became the intestate heirs. This conception has been adopted by modern law.

In default of testamentary disposition, the inheritance goes, first to descendants ${ }^{3}$ - (1st class according

${ }^{1}$ Cf. Sohm, Inst., sec. 98; Salkowski, Inst., sec. 182; Heusler, Inst. d. D. Privatrechts, sec. 183. Statutory heirs in the German Civil Code. See secs. 1924-1936.

2 Legal proverbs: "not man, but God, makes heirs"; "who would die a just and holy death must leave his property to his heirs." Walther Munzinger (Erbrechlliche Sludien, Basel, 1874) attempts to discoves the difference between Roman testamentary succession and German intestate succession by relatives, in the difference of notions as to the transcendental attitude and abiding place of the souls of the dead; on the one hand referring to the Roman home, and on the other to Walhalla. The ancient Indian law also did not recognize wills. See Jolly, Recht und Sitte, pp. 81, 84 .

${ }^{3}$ Particular legal systems make a distinction even among descendants, either according to sex or order of birth. Thus the ancient German law 
to Roman law, Novel 118). In default of descendants, to ascendants, brothers and sisters. of the whole blood, and their children-( $2 \mathrm{~d}$ class $)$. Then to brothers and sisters of the half blood, and their children-(3d class). Finally to the remaining collateral kindred(4th class).

The German Civil Code distinguishes statutory heirs of the first order, that is, descendants of the deceased; of the second order, parents and their descendants; of the third order,-grandparents and their descendants; of the fourth order,- great grandparents and their descendants; and of the fifth order,-remote ascendants and their descendants. A relative is not competent to take the inheritance so long as relatives of a previous order exist. The German Civil Code also makes provision for the spouse as an heir. The surviving spouse is entitled to one-fourth of the inheritance concurrently with relatives of the first order; to one half concurrently with relatives of the second order, or grandparents; and takes the entire inheritance in default of relatives of the first and second order and grandparents. In default of relatives and a spouse, the fiscus of the state to which the deceased belonged, is the statutory heir.

The law provides the details of the method of succession. Thus, in the German law, in the event of the death of a descendant, at the time of the accrual of the inheritance, his descendants related by blood to the intestate, take his share of the inheritance per stirpes. ${ }^{1}$

gave precedence to sons over daughters at least with reference to succession to land. The Hebraic law gave to the first-born a double portion of the inheritance. The ancient Greek law awarded to the daughter only a dowry or half of a son's portion. unless she were sole heir, in which case she took the entire property for her children.

With reference to primogeniture according to ancient Indian law see Julius Jolly, Recht und Sitte, p. 79. Concerning the dowry rights and rights of inheritance of the heiress in the law of the city of Gortyn see supra, sec. 15, page 106 , note 5 .

B B.G.B., sec. 1924, (3). 
The nearest relatives (above all, the parents and children in mutual aspect) should not in any case be passed over in testamentary disposition. ${ }^{1}$ They should be remembered at least with the smallest portion provided by statute - the so-called compulsory portion ${ }^{2}$ (Pfichtteil) - so far as no statutory ground of disinheritance ${ }^{3}$ exists. The relatives who are in this manner provided with a porticn which cannot be denied them, are called compulsory heirs or heirs of necessity (Noterben).

1 Roman Novel 115.

${ }^{2}$ Thus according to German law (B.G.B., sec. 2303), a descendant of the testator who is excluded from the inheritance by testamentary disposal may demand of the heirs a compulsory portion, that is half the value of the statutory portion. The same right exists in favor of the parents and the spouse under the same conditions.

${ }^{3}$ B.G.B., sec. 2333 . 


\section{SECTION 36}

\section{TESTAMENTARY SUCCESSION ${ }^{1}$}

The voluntary methods of disposition of inheritances at death recognized in legal systems include the following:-

I. Wills, which are formal, unilateral acts by which provision is made for an heir; or by which (at least according to German law) a final disposition of an inheritance is effected. ${ }^{2}$

According to form, wills may be distinguished as of various kinds, as they are executed with greater or less formality. According to the German Civil Code there are: (a) ordinary wills which are made (1) either before a judge or notary (sec. 2231), or (2) private wills, written entirely by the testator stating the place where and date when made and signed by his own hand (secs. $2231,2247,2248)$; and (b) extraordinary wills including communal wills (Gemeindetestament) (secs. 2249, 2252), wills of persons isolated [as by epidemic] (secs. 2250, 2252), of persons on board German ships [other than war-ships and while outside a German port] (sec. 2251), and military wills which may be made by persons in the service of the imperial navy under particular statutory provisions (Military Statute, sec. 44, Einf. G. z. B.G.B., Art. 44). According to content, wills may be unilateral or mutual, privileged and non-privileged, etc. Testamentary disposal of property was originally unknown

${ }^{1}$ Cf Sohm, Inst., sec. 99; Salkowski, Inst., secs. 176-181; Heusler, Inst. d. D. Privatrechts, sec. 194.

${ }^{2} C f$. supra, sec. 15, III, b, a; B.G.B., sec. 2064. 
to the Germans and first came into use in Germany, probably through the medium of the church.

II. Agreements of inheritance, which in the domain of German $1 \mathrm{aw},{ }^{1}$ are created the same as other agreements, ${ }^{2}$ by the concurrence of the wills of two or more private persons. Their characteristic is that they deal with the inheritance of property. ${ }^{3}$

These agreements are distinguished according to their objects as: contracts conferring rights of inheritance (pacta successoria affirmativa which may be institutoria, substitutoria, restitutoria, or conservativa), and contracts renouncing an inheritance (pacta successoria renunciatoria). Of a similar nature are Erbverbrüderungen and Ganerbschaften [pacta confraternitas, or agreements of the nobility providing for disposition of an inheritance in the event that a family fails of a male head].

A legacy (legatum sive fideicommissum, which originally were different forms) is a testamentary disposal of property (a delibatio hereditatis) which involves a singular succession, and not a universal succession of the property of the testator. ${ }^{4}$ If the testator has made provision for a legacy (which he might do by his will concurrently with the nomination of his heir, or in an agreement for a legacy, or in a special instrument called by the Romans, codicilli), and if the heir enters the inheritance, or does not renounce it, then he is personally obligated $^{5}$ to pay the legacy (Vermächtnis) to the

'Such agreements were not known in the Roman law; they were even prohibited.

${ }^{2}$ See supra, secs. 15, 23.

B.G.B., sec. 2278.

CF. B.G.B., sec. 2147.

s B.G.B., sec. 2174. The German Civil Code places the legatee simply in the position of a creditor of the inheritance, and allows the heir the right to deny satisfaction so far as the inheritance no longer extends. (B.G.B., secs. 1990-1992.) 
legatee (Fideicommissar, legatarius), or perform whatever other duty is provided for, in accordance with the testator's disposal.

The Roman law obligated the heir to pay testamentary legacies only to the extent that there remained to him at least a quarter of the inheritance the so-called quarta Falcidia. See Gareis, B.G.B., p. 330, note 1 . 


\section{B. PUBLIC LAW}

\section{SECTION 37}

\section{THE ELEMENTS OF PUBLIC LAW}

The function of public law is the legal regulation and protection of the dominant interests of the governing social entity. It proceeds from the proposition that the regulation and protection afforded by public law are in their nature legal; that is, made effective by means of command and prohibition operating on human will. The dominant interests of the governing entity do not rest simply on the protection of the law. They require also the protection of the power and might of the state and all its agencies.

The objects of this protection are dominant interests. The state however, also has private interests. Its private interests are such as are related to its fiscal capacity, in the protection of which private law applies. The dominant interests of the state relate to sovereignty and legal independence. Its fiscal concerns are dependent on, and subject to, private law. Legal independence, sovereignty, and absolute dominion, which distinguish the state (res publica) from all other social entities, are protected and furthered not only by means of force but also by standards of command and prohibition. Only the standards will be here considered. Collectively they make up public law. The dominant interests of the state are exerted in a two-fold aspect: (a) the stability of the state (Staatsbestand), and (b) the ends of the state. 
$A$. With reference to the stability of the state the following belong to its dominant interests:-

1. The interest of the state in its domain-free and legal control over the territory occupied: territorial sovereignty (Territorialhoheit);

2. The interest in free and legal control of persons belonging to its territorial domain: sovereignty over persons (Personenhoheit);

3. The interest in the control of things situate in, or belonging to persons attached to, its domain: sovereignty over things (Sachhoheit); and

4. The interest of freely and legally intrusting persons with the representation of its dominant interests: official sovereignty (Amtshoheit).

These interests must be recognized and legally established if the state would accomplish any of its ends. Therefore these interests may be designated as auxiliary interests.

$B$. The dominant interests relating to the ends of the state include:-

1. The interest of the governing community to exist as a unity; accordingly, to be representative of unity and to be recognized and considered as such (Repräsentationshoheit);

2. The interest in being able by a requisite number of persons to exert by physical power the forcible execution of its will, externally, and internally: military sovereignty (Militärhoheit);

3. The interest that its members shall live together in a state of peace: juridical sovereignty (Justizhoheit);

4. The interest that dangers threatening its stability (that is, its constituent parts: territory and things, people and officials) may be averted. Also, the interest that certain enterprises necessary to its constituent elements, and exceeding the power of individuals, may 
be carried out: its administrative interest or police sovereignty (Polizeihoheit);

5. The interest to draw by sovereign right on property ${ }^{1}$ existing within its domain and to apply the necessary material means for carrying out the interests, above mentioned; so far as these means are not of a fiscal character ${ }^{2}$ and therefore subject to private law: sovereignty of taxation (Finanzhoheit).

All of these primary and auxiliary interests are determined by historically variant notions of the objects of the state as such. They are represented by the state through its essential sovereignty and absolute independence. They are represented, however, in accordance with the idea of law; not arbitrarily, but legally, and within definite limits determined by law: that is by statute, custom, and legal necessity (Rechisnotwendigkeit). The limits by which the will of the state decermines itself, and by which this will is recognized as a legal will, are the basis of public law and govern its theory.

So far as the establishment of these limits deals only with the interests of a single state in relation to its subjects, public law in the narrow sense (Staatsrecht) arises. If the interests of states among themselves are concerned, and limitations over states by legal standards with protection of their common interests as such, then international law (Volkerrecht) presents itself.

In consequence of these observations, the elements of Staatsrecht are:-

1. Continuity of the governing social entity;

2. State interests derived from the ends of the state;

${ }^{1}$ By means of direct and indirect taxes, duties, monopoly taxes, privilege taxes, and licenses.

2 For example, through administration of state lands, domains, state forests, etc. 
3. Independence and sovereignty arising from the continuity of the state and the existence of state objects.

The elements of international law are:-

1. A plurality of governing social entities;

2. A recognized community of interests arising out of man's social life;

3. A uniform law for the governing entities derived from their common equality. ${ }^{1}$

1 The distinction between private and public law, see supra, sec. 14: the elements of private law, sec. 15. 


\section{SECTION 38}

\section{THE DIVISIONS OF PUBLIC LAW}

From a consideration of the elements of public law there arises the systematic division, public law of the state (Staatsrecht) (secs. 39-53), and public law of states among themselves (international law, secs. 54, 55).

State law classified on the basis of its most essential interests consists of:-

A. Constitutional law, or the totality of legal rules through which the dominant interest of the state in its continuity (Bestand) is legally secured: the state's sovereign interest in its own existence; and

$B$. Administrative law, or the aggregate of those legal standards by which the interest of the state in the exertion of its activity, in the execution of its objects, is legally defined and guaranteed: the state's sovereign interest in its own activity (administration in the widest sense). (Cf. supra, sec. 14, III).

The stability of the state $(A)$ implies or includes, the constituent parts of the state (sec. 43), and the organization of the state (sec. 44); from which the chief divisions of constitutional law are derived.

The activity of the state $(B)$ rests on a two-fold division. First, the legally protected declaration of public interests as legal advantages of the state by means of establishment of standards, viz. legislation. Second, the legally regulated, practical execution of all recognized interests belonging, or necessary to, the state: that is, administration of interests of the state, as distinguished from legislation. ${ }^{1}$

'See infra. sec. 45. 
An establishment of standards and administration of interests, constitute the sum total of state activity. ${ }^{1}$ The interests, however, which are protected by the erection of standards, and which are to be fostered and promoted by a legally regulated administration, ${ }^{2}$ are either:-

(a) Primary interests (sec. 37, B, supra); or

(b) Auxiliary interests (sec. $37, A$, supra).

Among the primary interests of the state, the most important in this connection, is the legal interest of the state which relates to its juridical sovereignty. This legal interest is served by legal standards which are arranged under the following titles:-

Civil law (sec. 49) (bürgerliches Recht);

Civil procedure (Zivilprozessrecht) (sec. 50);

Criminal law (Strafrecht) (sec. 51);

Criminal procedure (Strafprozessrecht) (sec. 52); and Administrative justice (Administrativjustiz) (sec. 53).

1 See infra, sec. 46.

2 See infra, sec. 47. 
[FIRST DIVISION OF PUBLIC LAW]

\section{PUBLIC LAW OF THE STATE}

\section{CHAPTER I \\ THE STATE AS SUBJECT OF STATE INTERESTS}

SECTION 39

STATE LAW-GENERAL PART

(Nature of General and Particular State Law)

State law (public law in a narrow sense) is the totality of legal rules by which the dominant interests of the state (ihat is to say, the interests of the state to have an existence and be dominant as such) are legally defined, and protected by means of standards.

Every governing community or state, has a state law peculiar to icself. It has at least, in substance, a constitutional law. Every governing community may be definitely distinguished from every other governing community, among other things, by its state law. ${ }^{1}$

The variations of state law among the several states are of greater importance than the differences of private

${ }^{1}$ Cf. Carl Binding. Deutsche Staatsgrundgesetze in diplomatisch genauem Abdrucke (Lcipzig, Wilh. Engeimann, 1892-1897, 10 Hefte); Felix Stoerk, Handbuch der deutschen Veriassungen (the present constitutional law of the German Empire and its confederated states-Leipzig, Duncker u. Humblot, 1834, - this work contains the complete and accurate statutory text); Paul Laband, Das Staatsrecht des Deutschen Reiches, Tübingen, 4th ed., 1901: (this work not only exhaustively discusses German legal standards, but also explains numcrous portions of general state law from new points of view, with original commentary of great import); also, see the literature of genetal and particular state law, in Hcinrich Marquardsen's collaborated work, "Handbuch des offentlichen Rechts der Gegenwart in Monographien" (Frieburg $i$. B. and Tübingen, 1883), from which foundation followed thrce addi- 
law among them. Consequently a transfer of the public law from one state to another is much more difficult than a similar reception of civil standards. A comparative or systematic consideration of the variations of public law of different states is not only possible, but necessary. It is the guide of general public law, which is the systematic review, or theory, of those legal rules through which the various states legally secure representation of their sovereign interests in legislation and administration.

This theory (so-called general public law) ${ }^{\mathfrak{l}}$ is based on the particular state law (besonderes Staatsrecht) of individual states, and forms a part, not only of the system of legal science, but also of the science of the state $^{2}$ (Staatslehre). The latter does not regard the state in the legal limitations and legal security of its stability and its pursuit of interests. This science considers the state simply as a political power in the totality of iis relations. The science of the state, therefore, is concerned with the facts of the origin and evolution of the state as an organization made up of land and people. ${ }^{3}$

tional volumes dealing with the public law of the various divisions of the German Empire, and other countries. [The detail of these volumes is omitted in this translation.]

With reference to German state law, see in addition to the works mentioned: Hermann Schulze, Lehrbuch des deutschen Staatsrechts, Bd. I, 1881: Bd. II, 1886; Ph. Zorn, Das Staatsrecht des deutschen Reiches; Bd. I, 1880; Bd. II. 1883 (2d ed., Bd. I, 1895; Bd. II, 1897); A. v. Kirchenheim, Lehrbuch des deutschen Staatsrechts, 1887 , also note literature cited in the same work pp. 96, 97; Gg. Meyer, Lehrbuch des deutschen Verwaltungsrechts, Part I, 1883, Part II, 1885; Adolf Arndt, Reichsstaatsrecht (1900). and Staatsrecht und Vcrwaltungsrecht in Birkmeyer's Enz., p. 741 and literature there noted, particularly p. 763.

'For the literature see Gareis, Allgemeines Staatsrecht in Marquardsen's Hdbch.d. öffentlichen Rechts, Bd. I, p. 3.

${ }^{2}$ Robert v. Mohl, Enzyklopädie der Staatswissenschaften, 2d ed., 1872. sec. 9; v. Holtzendorff, Rechtsenzyklopādie, p. 1010; Held, Grundzüge des allgem. staatsrechts oder Institutionen des offentlichen Rechts (Leipzig, 1868): Bluntschli, Geschichte des allgem. Staatsrechts und der Politik (1869); E. Frantz, Die Naturlehre des S'aats als Grundlage der Staatswissenschaft (1870).

${ }^{3}$ Public statistics is also to be named here. Cf . Robert v. Mohl, op. cit., secs. 112-114. 
It concerns itself with the objects ${ }^{1}$ of the state, its ethical significance, ${ }^{2}$ its economic problems, ${ }^{3}$ the conditions essential to life, its financial side, its devolution, and the methods and consequences of its destruction. It also deals, concurrently with these inquiries, with a comparative examination of state law; and to this exient, general state law is a part of the science of the state.

The notion of the state as well as the objects and the theory of its genesis may be derived from the science of the state. Every state is a sovereign community. This idea involves two elements: the community is one of land,-the territorial domain; and it also consists of persons, - the subjects of the state. Sovereignty signifies a free and independent activity based on a self-assertive choice of interests; as well as the means of expressing these interests against entities other than the state, by authoritative force. The notion of sovereignty, therefore, also implicates two elements: legal independence and legal organization. That is to say an organization of superior and inferior members, having for its object the realization of the will and power of the state in an independent expression of its interests.

'See infra (sec. 40), the teleology of the state.

2 Doctrine of public morals, see v. Mohl, op. cit., secs. 79-85a.

3 Political cconomy within the state and business activities of the state, see sec. 41 , infra. 


\section{SECTION 40}

THE OBJECTS OF THE STATE ${ }^{2}$

\section{(Teleology of the State)}

Philosophically, there are two opposed viewpoints in the conception of the ends of the state. According to one notion, that of Kant, the state is designed solely to afford legal protection to its members in an equal degree. Its purpose is that each may enjoy the greatest possible freedom, solely through an equal freedom of all others. This is accomplished by a limitation upon the spheres of activity of all members of the state. Such a state, limited solely to a protective activity, is called a Rechtsstaat, in a narrow sense. In an economic sense, it is known, also, as the Manchester state, the free-trade state, or the laissez-faire, laissez-aller state. In this state, individual activity is the chief thing. Individual activity is the basis of the advancement of civilization and the progress of humanity. According to the theory, this advancement can only be promoted by keeping level and open the road upon which individual activity is exerted.

A variety of welfare-theories stand opposed to the theory of the Rechtsstaat. They have in common, that they do not regard the state as having simply a negative legal function, or as only making a way for individual activity. According to these theories, the state also has an end to attain by positive action. This object is perceived as public welfare (salus publica). Sometimes this end is regarded more in the material sense; as by

${ }^{1} \mathrm{R}$ Gneist, Der Rechisstaat und die Verwaltungsgeschichte in Deutschland. (see p. 29). 
Fichte and others. Sometimes it is regarded as the dominion of moral law; as by Hegel and others.

Historically considered, public welfare is always an end of the state. There has never been a pure Rechtsstaat. Even in the narrowest limitation of the purpose of the state required by the Rechtsstaat, a recognition and realization of public welfare are necessary to the law of sovereignty. ${ }^{1}$ The furtherance of general welfare must be present even in the Rechtsstaat. What is to be understood by the expression, "general welfare," is, however, a matter of the greatest diversity of opinion. Pure reflection and simple abstraction will not afford an answer having any political practicality. Consideration must be given to all the factors of influence on civilization,- to the Volksgeist, to history, to the character of the land occupied, and the disposition of the people. The sphere of activity of the most ancient states appears to have been one narrowly limited; even when it went far beyond the confines of a simple Rechtsstaat. Every effort to define the modern function of the state abstractly, is involved in political controversy; if the meaning of "welfare" is to be sought by reference to a particular state.

Considered historically, legal protection and military defense appertain to the welfare of every state. Even in this limitation of the welfare of the state, there is much difference of opinion as to the measure of direct and proper activity of the state in affording legal protection; and as to the measure of claim that the individual may have in matters of military defense. It follows that church polity, and economic theory of the state, become the peculiar justing place for the controversies of state teleology.

1 For proof of this see R Gneist, op. cit., p 32, also Gareis in Hartmann's Zeitschrift f. d. offentl. Recht., Bd. III (1877), p. 137. 
The constitution of the German Empire of April 16, 1871 specifies in its introduction as the object of the permanent Bund creating the Empire: the protection of the imperial domain, the protection of the laws, and the furtherance of the welfare of the German people. 


\section{SECTION 41}

\section{THEORIES OF THE STATE}

The so-called theories of the state relate to the objects of the state; to the range and intensity of the activity of the state as compared with the activities of private persons; and to the origin of the state.

$A$. A consideration of the objects, or teleology of the state, involves the distinction above discussed, between the Rechtsstaat and the welfare state.

$B$. A consideration of the relation between state and private activities (that is of the community and the individual) involves the following distinctions:-

(a) The Rechtsstaat; that is, that form of state which permits the widest scope to private activity, and most narrowly restricts the activity of the state. The necessities of community life are regarded in this form of state purely as private matters to be fostered and protected solely by private law.

This state is based on the exalted conception, that moral conduct has a value and thrives only in freedom; and that in moral conduct, alone, the complete furtherance of civilization and mankind is possible. The economic conception of this state requires the smallest possible restriction of egoism in order that it may attain its ends in the greatest possible degree from every standpoint. This leads to the extreme form of the Manchester state and the pure laissez-faire, laissezaller state, in which, with the greatest equality of all, the protection of individuals (especially the economically weaker) diminishes to the same extent that a 
limitation upon all persons, in the interest of freedom, is decreased.

(b) The police state (Polizeistaat), or the state which regards the necessities of community life, essentially and in the first degree, as necessities of the dominant community. In this state, the activity of the state is accordingly greatly extended. Private enterprise is at all times overshadowed in detail, and controlled, protected, and supervised; with the result, that the discretion, as well as the power of the dominant social entity, universally ${ }^{1}$ overrules the judgment and force of the individual.

The extreme form of this conception leads, in the domain of religion, to the strict church state [Staatskirchentum in which the church and state are coincident: either with the worldly element predominant as in the Roman Empire and Greece, or with the spiritual element foremost as in the Judaic state] varying with every deviation of creed. From the economic side, however, this form of state leads to socialism ${ }^{2}$ in which private enterprise is considered, directed, and controlled, simply as a part of social activity; and social activity is regarded as the activity of the state.

(c) The Kulturstaat (culture state); the theory of which is the mean between the Rechtsstaat (legal state) and the police state. It is now the dominant form. It proceeds from the limited basis of the Rechtsstaat; but does not exclude the conception and activity of the police state, in so far as may be necessary, in the interest of attaining its cultural ends. Where a necessity arises, requiring satisfaction (which necessity the community should not suffer to remain unsatisfied) which exceeds the intelligence and power of individuals (but which

\footnotetext{
1 Where this has clearly been the case, the activity of the state has undeniably been exerted from every side, as in autocracies.

${ }^{2}$ Cf. Gareis in Annalen des Deutschen Reiches (1879), pp. 289, 290, 291.
} 
does not transcend the power or intelligence of the community), then in such case, occasion for positive interference on the part of the state presents itself.

Whether in those cases, in which a necessity is actually satisfied through the action of individuals, or by free social activity, a better, more complete, or more secure satisfaction could be accomplished by state activity, and whether the intrusion of state activity should be permitted, and private or social activity should be denied, are questions to be determined according to the particular case.

So far as an abortive satisfaction of necessity affects only the individual, or on ethical grounds appears as a lesser evil as compared with the mighty interference of the governing community, there the state may refrain. But where insufficiency of satisfaction opposes an interest of the community, there the activity of the state is indicated as advisable.

C. Theories of the state as relating to its origin deal with the question, whether the state arose out of the family; whether out of a relationship based on force (tyranny), of which the state as evolved from a land ownership relation (the patrimonial state) appears as a derivative; or whether it arose out of contract as postulated under variant notions by Hobbes, Locke, and Jean Jacques Rousseau.

History, without furnishing the conclusive particulars of the first and most remote origin, shows states which have sprung from each of these three sources. The patriarchal and kindred state arose out of the family. The hero and retainer state, like the patrimonial state, developed from the personal supremacy of a dominant chieftain. Modern confederated states, like the German Empire, owe their origin directly to agreement. 
Associated with theories of the state are the theories regarding the nature of confederated states; the distinctions between a personal union [e.g., Luxemburg and Holland up to 1883] and a real union [e.g. Austria and Hungary]; the differences between unitary and composite states, and imperial and federal states; as well, also, as the theories relating to the question of the necessity or divisibility of sovereignty. 
CHAPTER II

THE LAW GOVERNING THE ACTIVITY OF THE STATE

\section{SECTION 42}

\section{THE ORGANS OF EXPRESSION OF STATE POWER}

The state is the governing social entity. It rules over all its parts, members, and constituent elements, in order that it may supremely represent its interests; that it may make its will effective as the will of the community; and in order that this will may be carried out as the will of the community. In other words its activity is directed to the end that interests may be recognized, willed, and enforced as social interests. The dominant community, accordingly, has juristically a will-the will of the state. This will is of course, a legally independent or sovereign will. It is accompanied by power-the might of the state-which is likewise legally independent and sovereign. Sovereignty is essential to the state. It subsists in legal independence and a legal possibility of determination and establishment of what interests the state will regard and prosecute as its interests agreeable to the nature of this independence. ${ }^{1}$ History shows that the sovereignty of states not infrequently has become restricted, and that it is to be regarded as susceptible of limitations; not-

${ }^{1}$ Cf. Gareis, Allgemeines Staatsrecht in Marquardsen's Handbuck des offentlichen Rechts, sec. 10. 
withstanding the theoretical contradiction involved in the cutting down of sovereignty. ${ }^{1}$

This sovereign will and sovereign power belong to the state as the actual holder and bearer of governmental dominion. In order, however, to be able to express this will and power, the governing community requires certain organs for such expression. These organs come into existence originally as organs of the state with the same instinctively operating natural necessity, as the state itself originally arose and became dominant. It is possible that an organ of the state, such as the chief organ, the head of the state, may have been in existence before the state itself, and that the elements of the state may have grouped themselves and crystallized around this head. The hero, the retainer, and the patrimonial states are distinct proofs of this action.

The organs which the state requires to survive, that is, to realize and represent its interests, and in order to govern: that is, the organs requisite for the legally independent recognition and representation of its interests: or otherwise stated, the organs which appertain to an expression of the will and the power of the state, are:-

1. The head of the state;

2. The participating members ${ }^{2}$ of the state who in an independent manner, cumulatively, or collectively, express the dominant will of the state concurrently with the head of the state; or who autonomously ${ }^{3}$ occupy the place of the head of the state in the expression of governmental dominion;

1 This matter is the subject of much controversy. See Laband, Brie, Gg. Meyer, Hảnel, Dahn, v. Holtzendorff, Jellinek, Rosin, M. Seydel, Trieps, and $\mathrm{Ph}$. Zorn. For the literature see Gareis, op. cit., pp. 31 32, 104.

2 Thus, popular representation in constitutional monarchies of the present day, according to the provisions of their constitutions.

${ }^{3}$ Thus, autonomous, provincial, and colonial governments. 
3. The participating members and forces of the state subordinate to the head of the state, in part formally, and in part, also, substantially dependent on the head of the state, in the expression of dominion. ${ }^{1}$

With reference to the head of the state: the most obvious and powerful expression of unity of the will and power of the state is seen in the oneness of the state head. It is found in the most conspicuous manner where the head of the state is a physical person who is the organ of expression and execution of the will of the community with reference to all matters of state sovereignty. Such is a monarchy. Necessarily, there attaches to the head of the state the right of dominion and government, including the most important right in public law,the right to represent the state in all its functions, $j u s$ reprasentationis omnimoda. In addition, there may attach to the head of the state as a matter of public law, the so-called right of majesty-the supreme privilege of personal irresponsibility and inviolability.

There may be distinguished, according to the unitary or plural character, and the accountability or unaccountability, of the head of the state, as well as the existence or lack of constitutional control of public acts of the head of the state:-

I. Unitary government: 1, monarchies: (a) autocracies, ${ }^{2}$ (b) constitutional monarchies; ${ }^{3} 2$, monocratic republics: (a) presidential republics, ${ }^{4}$ (b) consular republics, ${ }^{5}$ and $(c)$ dictator republics. ${ }^{\circ}$

\footnotetext{
1 Thus, the highest councilors of the head of the state, the ministers, and the courts; all popular magistrates, all other officials, authorities, and officers down to the lowest executive organs of the will of the state.

2 Thus, the Russian Empire [1905].

${ }^{3}$ Cf. the constitution of the kingdom of Prussia (Jan. 31, 1850), and of Bavaria (May 26, 1818).

- $C f$. the constitution of the republic of $\mathrm{F}$ rance (Feb. 25, 1875).

${ }^{2}$ Cf. the constitution of the republic of Rome. See Mommsen, Rom. Staatsrecht. 2d ed., Bd. II, p. 74.

- This calls to mind the institution of government in ancient Rome of the time of the republic: See Mommsen, Röm. Staatsrecht, 2d ed. Il, p. 159.
} 
II. Plural government: 1, pleonarchies: (a) coregencies, ${ }^{1}(b)$ supreme councils; ${ }^{2}$ and 2 , pleonocratic republics. ${ }^{3}$

The participation of independent agencies, concurrently with the head of the state, in the government of the state, may be international or national. International participation occurs when an officer of another state, independent of the head of the state of his residence (such as a consul) has a share in the expression of government, by reason of treaty or convention.

National participation occurs in a highly diversified form, according to the national elements involved. It varies from the simple popular assembly such as the Roman comitia, the thing, and the Landsgemeinde, up to the unicameral and bicameral systems of modern constitutions, ${ }^{4}$ and the referendum ${ }^{5}$ of the Helvetian league. The part taken in government by the head of the state is, in all cases, distinguishable from that of popular representation, in that there devolves upon the former, initiative, leadership, and direction in government. The function of the head of the state, therefore, essentially differs from that of popular representation. State headship implies stability, continuity, and a profound influence on social life. Popular representation involves substantially only a right of acquiescence.

1 Thus, the joint emperors in the Roman Empire. See Mommsen, loc. cit., II, p. 1089.

2 The head of the state in confederated states, that is the personified association of states, may be reckoned here. The juristic unity of the confederated heads of the various states, is the bearer of legal sovereignty. Accordingly, the federal council of the German Empire is the representative of legal sovereignty. See Zorn, Staatsrecht des Deutschen Reiches, Bd. I, pp. 90, 92. The right of majesty and the præsidial right belong to the king of the Prussians in the German Empire. See Zorn, loc. cit., sec. 7.

${ }^{3}$ Cf. Gareis, Allg. Staatsrecht, sec. 12, pp. 36-40.

4 With reference to the representation of the German people in the Reichstag see Imperial Constitution, art. 20; Zorn, Staatsrecht, sec. 8.

${ }^{5}$ IOn popular participation in law-making, see Lobingier, The People's Law (The Macmillan Co., 1909).] 
The organs ${ }^{1}$ of government subordinate to the head of the state participate by virtue of the official sovereignty belonging to and wielded by the head of the state. $^{2}$

1 With reference to imperial officers sce Zorn, op. cit., secs. 9. 10.

${ }^{2}$ See sec. 37, supra, and sec. 47, A, 4, infra. 


\section{SECTION 43}

THE METHODS OF EXPRESSION OF THE POWER OF THE STATE

I. The totality of state activity, or expression of governmental dominion, is the representation of interests of the state. For this, the dominant social entity chiefly has its being; and in this, it has its strength. This activity consists of,-

(a) Legislation; and

(b) Administration, in the widest sense.

(a) Legislation is that activity of the state by which interests of the state are declared as such; by which they are placed under the legal protection of a standard; and by which they are elevated to legal advantages. This elevation of interests to legal advantages arises from standards; - through commands and prohibitions established under the sovereignty of the state. The content of these standards is not necessarily always expressed by the state itself. Their general authority and validity, however, must always be created by the authority of the state, without which law cannot exist. The nature of legislation and the kinds of laws have already been considered. ${ }^{1}$

(b) The whole remaining (that is non-legislative) activity of the state is called administration in the widest sense. It is that activity which proceeds from, or perhaps is inspired by, the head of the state. At any rate it is either nominally or actually accompanied by

${ }^{1}$ See supra, sec. 3, III; sec. 8 and sec. 11. Cf. Gareis, Allgem. Staatsrecht, secs. 43, 44 (pp. 116-121) in Marquardsen's Handbuch des offentl. Rechts, Bd. I. Concerning legislation in the German Empire see Zorn, op. cit., pp. 238, 407. 
an exercise of governmental dominion in the realization of the ends of the state, within the scope of legislation.

The most diverse kinds of regulations appertain to this exercise of dominion, as determined by considerations of politics, expediency, technical knowledge, etc. It may consist in the sending out and reception of ambassadors, the making of international agreements, the drafting and training of military recruits, the organization and direction of armies, the erection of forts and the planning of strategic operations; the erection of court buildings, the appointment of judges and other officers of the administration of justice, the pronouncement of judgments, the execution of judgments by force, the imprisonment and execution of offenders; the working-out of plans of finance, the making of loans by emission of state obligations, the levy of taxes, the management of forests and other landed property of the state, the control of boundary matters, and the imposition of duties; the conduct of examinations for physicians, and a variety of officers, the establishment of hospitals, the promotion of industrial and other expositions; and a manifold number of other acts for the attainment of the ends of the state, which lie within the wide scope of state administration. This activity is not simply that of execution of legislation, but it may proceed independently to the extent that legislation has not imposed restrictions upon it. ${ }^{1}$

Administration, as opposed to legislation, embraces,-

(a) The administration of justice;

(b) Administration in the narrow sense; that is, the practical expression of governmental dominion in the realization of the ends of the state, apart from the administration of justice. Its object is the furtherance

\footnotetext{
1 The relation between legislation and administration, see Gareis, op. cit.. p. 117.
} 
of public welfare in a variety of ways, within the limits of law according to the requirements of expediency and necessity; thus, military administration, finance, police, etc., and

(c) Administrat.ve justice (sec. 52).

II. From another point of view the kinds of expression of state dominion may be distinguished, accordingly as the state represents its own interests alone and independently, as a self-contained unitary state; or as it in part, at least, represents interests in combination with other states in a more or less intensive connection with such other states. This pursuit of interests may, therefore, be that of,-

(a) An isolated unitary state;

(b) A combination of states united in international agreement; or

(c) A constitutional combination of confederated states.

(a) When a unified and exclusive governmental power is exercised for the objects of a community in the representation of all the necessary, direct or indirect interests of this concrete governing community, then this community may be recognized as a unitary state. Its divisions, even when they enjoy a certain autonomy, are not therefore states. But one state power, and but one state will are operative among these various divisions.

(b) A joint pursuit of interests conformably to agreement, as in the case of alliances, confederations, and leagues, does not legally affect the organic law of the separate states. Such combination presents a common representation of interests of the confederated states; just as in the case of associations in private law, where there is a mutual independence of personality. The interests in common, thus prosecuted by agreement, are 
without exception, the individual interests of the confederated states.

(c) In compound states (unions), however, interests are pursued which are not necessarily interests of the individual members of the compound state, but are interests of the aggregated state itself. This, at any rate, is the case in the most important form of unionthe Bundesstaat. ${ }^{1}$

The present German Empire, the Swiss confederacy, and the United States of North America are examples of the Bundesstaat. The nature of the Bundesstaat, as it occurs in the German Empire, does not exclude the existence as actual states of the members which compose it, in the strict sense of the term state; ${ }^{2}$ inasmuch, as the first essential of the notion of state.--sovereignty,appears in these members, and, in fact, in an independent character. The sovereignty of the king of the Prussians is not a sovereignty derived from the empire, but is independent. $^{3}$ Likewise is the sovereignty of the king of Bavaria, and the remaining German princes. The

\footnotetext{
1 Concerning the German Empire (which is of this form) according to the constitution of April 16, 1871, see supra, sec. 8, page 71. note 1: sec 11 page 85 , note 1 , and sec. 39 , note 1 .

${ }^{2}$ Contrary view: Zorn, Das Staatsrecht des Deutschen Reiches, Bd. I (2d ed.), p. 84 .

Contrary view: Zorn, op. cit., p. 80, who arrives at the conclusion, from the legal character of the empire, that the residuary legal spheres of the individual states are to be considered as derived from the empire. Hanel, Staatsrecht des Deutschen Reiches, argues against the derivation of the law of the empire from that of the individual states. The establishment of the empire, however, is certainly referable, historically, to the contractual abandonment of the rights of the separate states: even though it be admitted, that out of this renunciation, there arose a new, and sovereignly independent law in the sovereignty of the empire. The historical origin of the German Empire; the devolution of the o'd empire which existed from the Carolingian period up to 1806; the existence of the German Bund (1815-1866): the establishment of the North German Federation: and finally the extension of the last into the empire by means of the imperial constitution of April 16 . 1871, are treated in the works on German state law. Cf. Laband, St. R. des Deutschen Reiches (4th ed.); Arndt, in Birkmeyer's Enz., p. 768; and see the literature noted in sec. 39, supra.
} 
inter-independence of the states and the empire among themselves arises logically out of the limitation of sovereignty. The empire and the separate states limit themselves as to the things in which they each recognize the competence of the others.

III. The legal standards by means of which the various kinds of state expression of governmental dominion derive their legal independence (whether in legislation or administration, and whether in unitary or composite states) - that is to say, the standards for a legal exertion of the force of the state-are divided into (a) constitutional law (sec. 44), and (b) administrative law (sec. 45). 


\section{SECTION 44}

\section{CONSTITUTIONAL LAW}

\section{(State Law in the Narrow Sense)}

"Constitutional law" or "state law" stricto sensu means those standards through which the fundamental stability of the state and its organs is legally regulated and protected. Constitutional law therefore embraces:-

1. The legal standards concerning the position of the head of the state as the highest organ of the state. This means the legal standards relating to the stability of the head of the state; the acquisition and loss of the attribute of state headship; the fundamental legal principles concerning the governmental dominion of the head of the state; the law of government and majesty; ${ }^{1}$ and the primary legal rules relating to the exercise of governmental dominion in general. Thus, personal command, ministerial accountability, divided or constitutionally limited exercise of governmental dominion - the official sovereignty of the ruler;

2. The legal standards governing the participants in the exercise of government, particularly in national participation. This embraces the standards relating to general popular representation in government: provincial estates, and parliaments, and their stability, objects, rights, and duties. It includes also the standards

\footnotetext{
1 The working-out and basis of these rights are highly diverse: see on one hand, the rights of chieftainship in lower civilizations, in Bauer, Die Strafrechtspflege über die Eingeborenen in den deutschen Schutzgebieten (Archiv. f. offentl. R., Bd. XIX, p. 44); on the other hand see the theocratic conception of these rights among the ancients as in the Code of Hammurabi (sec. 2. note 1 , supra).
} 
relating to participation in the exercise of government by means of special popular representation as in the case of provincial assemblies, and in other forms of special popular representation; as where the lay element has a governmental activity in various ways co-ordinately with the governmental element;

3. Legal standards for substitution of the head of the state; thus in the case of autonomous corporations, self-governing communities, and vicegerental government;

4. The objects of government, and the legal limits of government with regard to its objects:-

(a) Persons, particularly subjects of the state (Untertanen), ${ }^{1}$ their constitutional rights; communities, and the law of communities;

(b) Things, and in particular, the territorial domain;

5. The legal guaranties of the constitution.

Constitutional law, as opposed to administrative law, ${ }^{2}$ does not deal with the consideration and legal limitation of the activity of the organs of the state. The prevailing popular and doctrinal usage is otherwise. According to this usage, legislation, is legally involved in constitutional law. Constitutional law includes, in its narrow sense, according to modern usage, in the consideration of the functions of the organs of legislation, the details of these legislative organs in the ascertainment of the requisites of laws. The legal standards applicable to the other governmental groups - of administration in the widest sense-belong to constitutional law only in so far as necessary to distinguish

\footnotetext{
1 Legal standards must, in every instance, determine the matter of the acquisition and loss of nationality. Cf. Emil Szanto, Das griechische Bürgerrecht (Freiburg i. B., 1892). Concerning German nationality see imperial statutes of June 1, 1870, and August 16, 1896.

${ }^{2}$ See secs. 14, 38, supra, and 45 , infra.
} 
the organs of administration from the organs of legislation; or so far as they establish limits in the interest of the constitutional rights of persons. ${ }^{1}$

${ }^{1}$ Cf. Georg Meyer Lehrbuch des deutschen Vervaltungsrechts, secs. 1, 2: A. von Kirchenheim, Einführung in das Verwaltungsrecht (1885), pp. 3, 21. 


\section{SECTION 45}

\section{ADMINISTRATIVE LAW}

The aggregate of the activities of the state, as already shown, ${ }^{1}$ consists of legislation and administration. Both these groups of activities are governed by legal standards. The standards relating to legislation are considered in connection with constitutional law, as pointed out in the last section. Administrative law, therefore, covers the entire remaining bulk of legal standards relating to the activity of the state in public interests. These standards are not such as deal with the declaration of state interests. They relate to the actual administration of these interests.

In this sense, administrative law embraces the legal standards for the administration of every sovereign right of the state. It includes juridical sovereignty, military sovereignty, fiscal sovereignty, representative sovereignty and police sovereignty. It must, however, be borne in mind, that the administration of these various sovereign rights does not depend entirely on legal standards. Even juridical sovereignty is not administered purely according to legal standards. Frequently it is governed by considerations of expediency and other influences. These considerations preponderate in the remaining departments of administration. ${ }^{2}$ This circumstance may also furnish the basis of distinction between,- -

(a) Administration of justice; and

\footnotetext{
${ }^{1}$ Secs. 38,43 , supra.

2 The established rules of political economy have a legisiative and executive application in all internal administration. See sec. $43,1, \mathrm{~b}$, supra. and sec. 46, infra.
} 
(b) Administration, in the narrow sense, or the carrying-out of the sovereignty of the state, exclusive of the function of administration of justice. A further distinction is still possible of administration in the narrowest sense, - an internal administration of so-called police or administrative sovereignty ${ }^{1}$ (Verwaltungshoheit).

Administrative law, in contradistinction to legislation, is the totality of legal standards through which the actual representation of interests recognized as belonging to the state, or generally to be furthered by the state, is legally defined and therefore protected, secured, and also restricted. These limitations, in part, are found in constitutional law, and in particular in the constitutionally guaranteed rights of subjects of the state. ${ }^{2}$

1 See supra, sec. $37, \mathrm{~B}, 4$.

2 In lieu of further discussion of the notions "administration," and "administrative law," it will be sufficient to refer to the propadeutic work of A. v. Kirchenheim, Einführung in das Verwaltungsrecht, including an outline, Stuttgart. 1885. In the definition of these ideas, there will also be found highly valuable, A. v. Kirchenheim's Verwaltungsrechtspraktikum. Stuttgart, 1883. Further on this subject see G. Schönberg, Handbuch der politischen Oekonomie, Bd. II (Tübingen, 1882) and in particular part three: "Verwaltungslehre," by Gustav Rümelin, Georg Meyer, Ludwig Jolly, and Edgar Löning: L. v. Stein (1867-1869); by the last author, Handbuch de, lerwaliungslehre, (2d ed. Stuttgart, 1876); see also v. Inama-Sternegg. Varwaltungslehre in Umrissen, Innsbruck, 1870. 


\section{CHAPTER III}

THE OBJECTS OF THE ACTIVITY OF THE STATE

\section{SECTION 46}

\section{STATE SOVEREIGNTY AND STATE INTERESTS}

The activity characteristic of the state is that of legally independent governmental dominion. The object of this activity is the representation of state interests through which the ends of the state in general and the particular purposes of the state are attained.

The interests of the state are stated in the discussion of the elements of public law (sec. 37, B). The objects of the state in every state include the interest of internal and external unity (repräsentation), legal interests, military interests, administrative interests and fiscal interests. These interests are accordingly designated as directly leading to the attainment of the ends of the state. Indirectly, these same ends are aided by governmental interests in the permanance of the state: thus, by the interest in the state domain, in the people, in things, and in substituted functions (sec. 37, A).

The characteristic attribute of the state's governmental dominion is legal independence or state sovereignty. With this attribute the state represents every one of its chief interests and every one of its auxiliary interests. Accordingly each of these interests expresses the sovereignty of the state. Thus, one speaks of juridical sovereignty, fiscal sovereignty, etc., of the sovereignty of territorial domain, of official sovereignty, etc. 
The state is apprehended in all these functions as an entity of force, and as practically dominant. The state is, however, at the same time, also, a legal entity. ${ }^{1}$ Its dominion is a legal dominion. This may be put in a two-fold aspect: the state limits its own will in the recognition of the idea of law; and the state employs the notion of law for the purpose of executing its will in governmental dominion. According to the first notion, the self-limitation of the will of the state results as an opposite to the constitutionally recognized interests of others. The state will, or sovereignty, restricts itself to a legally circumscribed domain through this recognition of the interests of others. This will of the state, however, itself becomes law, in the same manner that law in general (sec. 5) and private law in particular (sec. 15), arise. Sovereignty leads to the law of sovereignty. Thus, we speak of the law of fiscal sovereignty, assuming legal limits to the fiscal sovereignty of the state. These legal limitations, as in all other cases, are established through command and prohibitions. The state employs the same means in the practical execution of its sovereignty. Therefore, in actual operation against other volitional entities and bearers of interests, the dominion of the state is a legal dominion.

1 The necessity of law and the fundamental principle of human reason make themselves practically effective in this idea; see supra, sec. 2. 


\section{SECTION 47

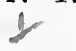 \\ THE LEGALLY PROTEC'TED CHIEF AND AUXILIARY INTERESTS OF THE STATE IN DETAIL}

The legally protected interests of the state are:-

A. Auxiliary interests (those relating to the permanance of the state):-

1. The interest in the government of the domain of the state. This interest is the basis of the law of territorial sovereignty. It is denominated an auxiliary interest; and is, as such, legally protected in order that it may be legally possible for the state to exercise territorially its remaining, and in particular, its chief sovereign rights, on its own territory, with an exclusion of all foreign influence. The domain of the state for the purpose of government is territorially divided into provinces, districts and other similar divisions. ${ }^{1}$ For the purpose of excluding foreign powers, the territorial boundaries are in part obviously fortified. ${ }^{2}$

2. The interest in the government of persons. This interest is the basis of the law of personal sovereignty. It does not exist simply with reference to subjects of the state whose position as such is a matter of accurate legal determination, ${ }^{3}$ and of which class, citizens form a part. It extends also to foreigners coming into legal contact with the state only in certain particular connections, subditi secundum quid. Of the latter are

${ }^{1}$ Concerning the historical reasons of divisions of the state domain see sec. 2, supra. With reference to the significance of the capital city, see Gareis, Allg. St. R., p. 139.

2 This calls to mind the armed separation of the Roman Empire from Germany through the limes; also the mark polity of Charlemagne.

${ }^{3} \mathrm{Cf}$. imperial statute June 1,1870 , and Aug. 16, 1896, with reference to acquisition and loss of nationality. 
Forensen [non-resident land-holding aliens]; sojourners so far as not exempted by international law; de facto Untertanen [persons who themselves, or whose parents formerly were subjects, also subordinate diplomatic and consular officers]; and Schutzgenossen [foreign subjects who are given consular protection by another state by agreement of the states concerned, in cases where the state to which the alien belongs has no consulate of its own].

The state legally demands the performance of duties, and in particular, requires the duty of obedience. This follows by force of the interest of the state in the government of persons. Obedience in particular requires the performance of statutory duties of service ${ }^{1}$ of which military service ${ }^{2}$ is the most important: to which may be added, certain special statutory duties (LieferungsDuldungs- und Unterlassungspflichten). ${ }^{3}$

The idea of law, which the dominant social entity espouses, ${ }^{4}$ nevertheless requires a limitation on all such duties. Accordingly, a restriction is required upon the personal sovereignty of the state. The object of this restriction is that the persons lying under duties may be recognized and protected as being vested with interests of their own, even as against the state itself. The legally recognized interests of subjects of the state are their private legal rights. ${ }^{5}$ Their so-called public or political rights are also protected and legally guaranteed to them, in the interest of the community, and by the community: thus, official rights, the right to vote, and also the so-called fundamental rights of mankind.

1 Cf. Gareis, Allg. Staatsrecht, sec. 55.

${ }^{2} C f$. the imperial statutes relating to military service of Nov. 19, 1867; May 2, 1874; May 6, 2880; March 11, 1887; Feb. 11, 1888; and Aug. 16, 1896.

${ }^{3}$ Gareis, op. cit., pp. 149, 150.

- See infra, sec. 47 and references there noted to previous parts of this work.

s See supra, secs. 17-36. 
The essence of the legal limitation of the will of the state and the possibility of the conception of the state as a legally dominant social entity, rest on the recognition of legal spheres, and the possession of interests in, and peculiar to, entities other than the dominant community. This requires an acknowledgment of personalities $^{1}$ within and alongside of the state. Such a personality may be that of a privileged individual (for example, a noble), or one non-privileged; ${ }^{2}$ or this personality may be that of a social entity within the state: the fiscus, ${ }^{3}$ churches, ${ }^{4}$ municipia ${ }^{5}$ foundations, etc. ${ }^{\circ}$

3. The interest in governmental dominion over property, or the sovereign law relating to things. To the exercise of this interest which is not to be confused with fiscal sovereignty, belongs every mode of employment of force in connection with property, ${ }^{7}$ and every species of expropriation. ${ }^{8}$

4. The interest in governmental representation ${ }^{2}$ or the sovereign law of officers. The legal standards which appertain to this interest relate to the legal powers and limitations of officers of the state through rights and duties.

1 See supra, sec. 15.

${ }^{2} C f$. the German Civil Code of Aug. 18, 1896, sec. 1 by which every species of slavery is prohibited.

${ }^{3}$ See supra, sec. 15.

- See supra, sec. 15, and infra, sec. 57.

5 See supra, sec. 7, also sec. 15.

- See supra, sec. 15.

7 German Imperial Civil Procedure Act, sec. 708.

${ }^{8}$ Cf. Gareis, Grundriss zu Vorlesungen über das deutsche bürgerliche Recht, secs. 82,83 .

9 That the head of the state may be omniscient and omnipresent requires the support and representation of persons who exert their knowledge and power in the exercise of sovereign rights in the name of the head of the state. Such support was given to the nobility in the ancient Germanic and Frankish period by their retainers (called in old high-German gasindi, and later degen) who in return were provided with protection and subsistence by the lord (who was called drost, ringspender, or brotspender, or lord (English) from hlâf-veard (Brotwart, or Brotspender). [See "lord" in Century Dictionary.] 
B. The chief interests (those relating to the object of the state):-

1. The interest in the recognition and assumption of unity and personality on the part of the state. This interest is first recognized in international law, and is even based on the nature and purpose of the state. Legislation determines which of the chief organs of the state shall exercise this sovereign right. In other words, constitutions provide the standards of recognition and protection of the general right of representation by the head of the state of state personality.

Felix Dahn shows in his Könige der Germanen how among certain German peoples this chiefest representation of the state arose out of an expressly recognized right of the head of the state in the embryonic state; thus among the Vandals (Part I, p. 213); among the East Goths (Part II, p. 107); and among the West Goths (Part VI, pp. 27, 509).

2. The interest in military force, or the sovereign law of inilitary power. Since the members of the state are legal subjects (that is to say, bearers of rights, having protected legal spheres of their own), therefore, the maintenance of duties of military service, etc., in short, obligatory restrictions upon freedom in the interest of the defensive capacity of the state, are of the greatest importance. These duties are imposed through military statutes, etc.

3. The legal interest (Rechtsinteresse) of the state and the sovereignty of justice, considered in the ensuing chapter.

4. The general interests of security and welfare, or the sovereign law of administration and police. The security and furtherance of the sovereign right of general welfare appertain universally to the state in the 
affairs of modern civilization, as a coercive right ${ }^{1}$ (Zwangsrecht). This is the so-called sovereignty of police. Practical legislation, as the state declaration of standards, has for its object the recognition of this sovereignty as a legal advantage. . It has at the same time, however, the function of legal definition and limitation of this sovereignty, and its protection as against the legal spheres of all others vested with legal rights. ${ }^{2}$

This activity of the state is directed, as the name designating the interest involved would indicate, toward two different ends. One of these ends is negative, and is directed against injuries which threaten the people, the country, or property, and provides security from dangers. The other, is a positive end, and provides for a direct furtherance and immediate advancement of the country and the people.

Positive ends of the state embrace:-

(a) The promotion of culture, or a fostering of intellectual interests, which includes the ordering of the relations of religious societies (see above, sec. 5, and below, sec. 57), the establishment of educational institutions, the furtherance of the arts and the sciences outside of schools (through academies, museums, libraries, etc).

(b) The promotion of welfare, or the fostering of creative works, mining, ${ }^{3}$ agriculture, ${ }^{4}$ forestry, ${ }^{5}$ hunting, ${ }^{\circ}$

1 For example, the medical police in the public care of health, compulsory regulations relating to vaccination, and compulsory education.

${ }^{2}$ Cf. Gareis, Allg. Staatsrecht, sec. 48 (examples, pp. 132-133; to which may be added the interest of the state in the maintenance of forests protected by forest police).

${ }^{3}$ Cf. Prussian mining statute of June 24, 1865, and 1892; the Bavarian mining statute of March 20, 1869; and mining in provinces under German protection (Gareis, Reichsges., Nos. 65, 248).

${ }^{4}$ With reference to agriculture in political science see Schönberg im Hdbch. der Staatswissenschaften; cf. R.G., July 6, 1904, with reference to the prevention of phylloxera vastatrix.

${ }^{3}$ Cf. Schappach, Forstwesen, and R. Hess, Forstschutz.

${ }^{6}$ Cf. B. Dalcke, Preuss. Jagdrecht (2d ed., 1888). 
fishery, ${ }^{1}$ industrial pursuits, ${ }^{2}$ manufacture, commerce (the mail), ${ }^{3}$ railroads, ${ }^{4}$ the telegraph, ${ }^{5}$ navigation, streets, etc., and also the advancement of institutions of money and credit (the political science of banking), ${ }^{\circ}$ the circulation of securities, etc.

(c) While the negative end of administration comes into the foreground in all of the problems of police security, taken in its widest sense, yet it is not exclusively applicable. Even in these activities, there are positive ends to be attained. Such is the case in the matter of health police, or the prevention and cure of diseases, and epidemics; in the supervision of medical art whether relating to man or beast, of apothecaries, etc. $;^{7}$ in the policing of order and security; in the regulation of insurance of persons and things whether relating to health, age, invalidism, or accident $;^{8}$ in police security in the narrow sense; in regulation of the building art; in the policing of paupers, etc.

5. The proprietary interest of the state, or the sovereign law of finance. It is no longer a matter of doubt that the governing social entity cannot be prevented by anything or any person from invading spheres of private right and drawing therefrom the proprietary materials necessary to the attainment of its ends. ${ }^{9}$ It is, how-

1 Cf. Preuss. Fischereigesetz of May 30, 1874.

2 Trade regulation statute (Gareis, R.G., 183-190).

Postal statute of Oct. 28, 1871; See Laband, Str. R., Bd. III, p. 40.

- Freight carrier statute (Gareis, K.G., 160-164).

s Telegraph statute (Gareis, R.G., No. 154).

- The bank statute (Gareis, R.G., Nos. 166, 260).

7 The vaccination statute (Gareis, R.G., No. 20); the cattle-plague statute (Gareis, R.G., Nos. 180-182); and the cholera statute (Gareis, R.G., No. 191).

${ }^{8}$ Health insurance of workmen (Gareis, R.G., 147, 148); age and invalidism insurance (Gareis, R.G., 103, 104, 131, 159); accident insurance (Gareis, R.G., 298-303).

- This fiscal sovereignty is distinguished from governmental dominion over things (sec. $47, A, 3$ ) according to the objects to be attained. By force of its fiscal sovereignty, the state levies taxes and imposes duties, for itself : and by force of its dominion over things it allows expropriation of property. and execution on property, in the interest of private persons. 
ever, equally agreed, that in a legally ordered state, this invasion of private right must proceed in a legal manner. This action will be permitted and taken only in accordance with those conditions which create law or which may abrogate it. It requires the recognition of a fixed standard, regulating in what manner and to what extent, private property may be turned into property of the state. 
CHAPTER IV

\section{THE STATE'S INTEREST IN LAW, AND SOV- EREIGNTY OF JUSTICE IN PARTICULAR}

\section{SECTION 48}

\section{ADMINISTRATION OF JUSTICE AND THE STATE}

I. It has repeatedly ${ }^{1}$ been stated that however different may be the ends of the dominant social community in other respects, that universally, the establishment of law, and the administration of justice are regarded as among its highest purposes. In advanced stages of civilization, the state has a vital interest in the realization of the notion of justice. ${ }^{2}$ All members of the state community who are not morally depraved recognize this fact. Their external relations conform to the necessity that the state for the attainment and maintenance of peaceable adjustments among themselves, must interpose $^{3}$ its authority, employ its agencies of force, and apply its governmental dominion.

The interest of the state in peaceable order among the members of society which arises out of the ethical views of influential persons within the state, ${ }^{4}$ and which sustains and directs the development of law, is of a two-fold character:-

(a) It has an interest that certain interests of individuals and of the community shall for the sake $\mathrm{k}^{5}$ of the

1 See supra, secs. $7,8,9,10$.

2 See supra, sec. 8.

${ }^{3}$ CF. supra, sec. 8 (the import of the authority of the state in the development of law).

Cf. supra, sec. 8.

${ }^{5}$ C. supra, sec. 46. 
notion of law be raised up to legal advantages, and be protected as such; and

(b) The state has an interest apart from the conception of law in the representation and furtherance of its own vital interests through legal standards.

This two-fold interest is satisfied on one hand by the activity of the state in legislation; in a recognition of interests as legal advantages by means of its declared

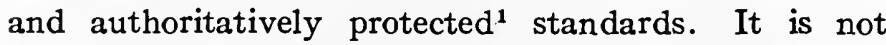
necessary, however, that all those standards by which legal advantages are created out of relations of fact, be expressly declared. In addition to legislation, there may be standards formulated by the community, to which the state lends its authority ${ }^{2}$ (custom, observance, etc.). ${ }^{3}$

This interest is satisfied, on the other hand, through the activity of the state manifested in the administration of justice. ${ }^{4}$

II. The promotion of justice or law is that administrative $^{5}$ activity which directly ministers to the interest of the dominant community in the existence of legal order. This administrative activity is based in every event on the authority of laws regulating justice. It is based on standards maintained by the authority of the state in a recognition of legal interests as legal advantages. It is the expression in all cases of the sovereignty of justice, or that sovereign law of the state which imposes legal limitations on the dominant power of the state in the execution of the idea of law.

${ }^{1}$ See notes referred to in the following note.

${ }^{2}$ See supra, sec. 6, page 37, note 2 ; secs. 8, 9, 10 (at end), and sec. 12 .

${ }^{3}$ See supra, secs. 9, 10, 12.

4 "Administration" in this sense opposed to "legislation," see sec. 43, I.

5 "Administration" in a wider sense including judicial activities. See supra, sec. 43, I. 
Public officers, as organs for the promotion of justice, are not universal or necessary. But every act in the advancement of justice is always founded on the authority of the state. Thus, in the Middle Ages, the grant of inferior and superior jurisdiction, the latter involving also Blutbann [causa Sanguinis]. Thus, also, the recognition and supervision on the part of the state of manorial or patrimonial jurisdiction. A further example is found in the public character of notarial acts, etc.

III. The administration of justice is either decisional (decisive, or judicially responsive, responsorisch-justiziell), or it is precautionary ${ }^{1}$ (kautelarische Rechtspflege). The functions of decisional justice are essentially exercised by courts ${ }^{2}$ in civil and criminal procedure, as well as in controversies relating to administrative law. Prudential justice proceeds from officers of justice as distinguished from courts, and is exercised by notaries, hypothecary officers, registering officers, and possibly also by courts-but by the last only as a subsidiary function. This latter administration of justice is called non-contentious jurisdiction (freiwillige Gerichtsbarkeit) (sec. 49).

Administration of justice in a wider sense embraces, alongside of legislation relating to justice, all the established measures and institutions of the state which further the idea of law, as follows:-

(a) The establishment of a judicially responsive administration of justice, through the creation and organization of courts.

(b) The establishment of a prudential administration of justice or non-contentious jurisdiction; and

(c) The establishment of a supreme administration over the functions of justice with a supervision of its

Cf. supra, sec. 13.

See infra in this section, division $\mathrm{V}$. 
organs: courts on one hand, and prudential officers on the other.

IV. The supreme administration over the affairs of justice by the ministry of justice, department of justice, the cabinet, or supreme officer of justice, involves the function of giving advice to the head of the state for the administration of the sovereign right of justice; of drafting statutes relating to justice; appointment and authorization of external organs for the promotion of justice, including the personnel of judges and auxiliary officers of justice, the officers of non-contentious jurisdiction, and to a certain extent, the members of the legal police (Rechtspolizei) $;^{1}$ and it also embraces the function of providing the external conditions for their activity, as by the establishment of court buildings, prisons, etc. In modern European states, the supreme authorities of justice in the execution of their duties, avail themselves of a professional, supervising and advisory organ or officer known as the counsel ${ }^{2}$ or attorney of the state who has authority to make complaint, in criminal cases, on the part of the state (sec. 50).

The bar $^{3}$ is an important organ in the prudential administration of justice, and it also has a certain indirect co-operation in the administration of justice by the courts. The bar has the function of giving counsel to private persons in their legal matters, lending professional assistance to, and representing, such persons in their legal controversies, and giving assistance in legal defenses against litigated claims of the state. ${ }^{4}$ The

${ }^{1} C$ f. for example, clerks of courts. See judicature statute, sec. 154 ; bailiffs, sec. 155; (Gareis, R.G., Nos. 261-262). [A wide application of the term "police" according to German usage is made apparent here.]

${ }^{2}$ Cf. judicature statute (Gerichtsverfassungsgesetz), sec. 142 (Gareis, R.G., 261-262).

${ }^{3}$ The statute of July 1, 1878, relating to advocates (Gareis, R.G., 93-94, 267).

'Cf. infra, sec. 50, page 267, note 5 . 
activity of the bar is regulated under the supervision of established rules which are created either by legislation relating to the administration of justice, or by the supreme authorities in the affairs of justice.

V. The state is the protector of positive law, and therefore also the protector of all individual rights which are defined or guaranteed by the state. This is in accord with the modern conception of sovereignty of justice which appertains solely to the state, and which recognizes $^{1}$ in jurisdiction not only an abundance of powers or rights, but also an abundance of duties. Every person, whose rights have been infringed and who, on that account, seeks protection or redress, must apply to the dominant, governing community. Even the state itself, in so far as it has a sphere of rights, applies as a legal community, to the dominant entity of force. Help, redress, or protection for which application is made to the state, is not afforded arbitrarily but in accordance with the notion of law-on account of which, application is made to the state-and only according to the standards and forms of the law. A characteristic establishment of courts ${ }^{2}$ vested with a decisional administration

' Cf. art. 29 of the final act of the Congress of Vienna of May 15, 1820 , and art. 77 of the constitution of the German Empire. See Laband, St.R. (4th ed., BC. III, pp. 349-350).

2 The legal foundations for the existence, competence, and organization of the courts, were unified, for the entire German Empise, by the enactment of the four great statutes of imperial justice (of 1877, effective since Get. 1 . 1879): and especially by the judicature statute (Gerichtsteriassungsgesetz) of Jan. 27, 1877, which contains a common basis for the procedure acts: the civil procedure act of Jan. 30, 1877, the criminal procedure act of Feb. 1 , 1877, and the bankruptcy act of Feb. 10, 1877, which came into force concurrently on Oct. 1, 1879. This fundamental legislation, relating to the administration of justice, within the German Empire, deals with judges (Richter) (secs. 1-12), jurisdiction (Gerichtsbarkeit) (secs. 12-21), inferior courts (A mtsgerichte) (secs. 22-24), assessors' courts (Schoffengerichte) [the lowest form of inferior courts in criminal matters consisting of a judge and two lay-members.-Schöfien, assessorsl (secs. 25-57), provincial courts (Landgerichte) (secs. 58-78), juries (Schwurgerichte) (secs. 79-99), commercial courts (Kammern für Handelssachen) (secs. 100-118). provincial courts of appeal (Oberlondesgerichte) (secs. 119-124), the supreme court (Reichsgericht) 
of justice is provided for in order that the idea of law may prevail. This class of officers in its functions of declaring rights and duties is independent of an arbitrary sovereign will, so far as this will is not expressed in legislation. ${ }^{1}$ (Prohibition of so-called cabinet justice).

According to the German judicature act (Gerichtsverfassungsgesetz), sec. 1, "judicial power shall be exercised by independent courts which are subject only to the laws."

The characteristic feature of the exercise of the functions of justice by the courts lies in this: that this activity arises only in a decisional manner, on the presentation of a claim, based on a legal standard. According to the varieties of legal standards involved the following kinds of claims are distinguishable:-

(a) Civil complaints (see sec. 49);

(b) Criminal complaints (see sec. 51); and

(c) Administrative complaints (secs. 45, 53).

Differences of procedure also depend on this distinction: thus, civil procedure (sec. 50 ), criminal procedure (sec. 52), and procedure of administrative justice (sec. 53).

(secs. 125-141), the public prosecutor (Staatsanwalt) 'secs. 152-153), clerks of courts (Gerichtsschreibern) (sec. 154), summoning and executing officers (Zustellungs- und Vollstreckungsbeamten) (secs. 155-156), legal redress (Rechtshilfe) (secs. 157-169), publicity, and judicial police [Sitzungspolizei, having power to punish for contempt] (secs. 170-185̄), legal terminology (secs. 186193), conference and decision (secs. 194-200), and judicial non terms ( $G e$ richtsferien) (secs. 201-204).

Concerning the civil procedure act, and the bankruptcy act, see infra. sec. 50 ; the criminal procedure act, see infra, sec. 52 . Each of these statutes was amplitied by special intioductory statutes (Einführungsgesetze) for the purposes of imperial legislation, and with the exception of the criminal procedure act, was re-enacted in new form on Jan. 1, 1900, amplified by supplementary legislation (Ausführungsgesetze) of the German states. There are special statutes governing jurisdiction in consular domains, and German provinces (April 7, 1900, and Sept. 10,1900, respectively). In ad dition to military courts, governed by the military penal procedure act (sec. 53, note 1 , infra), there are in Germany special trade courts (Gewerbegerichte) (see R.G., Sept. 29, 1901), and commercial courts (Kaufmannsgerichte) (see R.G., July 6, 1904: R.G.Bl., p. 266). Cf. Gareis, H.G.B. (3d ed.) XXIX, XLII, and sec. 9 , page 74 , note 1 .

${ }^{1} \mathrm{This}$ is a consequence of the recognition of a legal sphere of persons alongside of the sphere of power of the state. 


\section{SECTION 49}

\section{THE CIVIL LAW' AND NON-CONTENTIOLS JURISDICTION}

I. Civil claims are essentially those interests of private $l a w^{2}$ recognized and protected by standard in their offensive, or defensive, and consequently in their external form. The state, as an entity of power which is called upon for the protection of private persons (including the fiscus), provides the desired protection of these interests, not simply by reason of the fact that it is an organized force. It acts also because it has placed and must employ its governmental dominion in the service of the idea of law, when the premises are established upon which the civil law has based this protection.

The state, when applied to for protection, does not act arbitrarily. It proceeds according to the civil law; and then only through independent authorities, the courts (sec. 48, III, V). A determination is made as often as a claim for protection is presented if such a case is shown for which the external regulation of peaceable order has securely established the assurance of legal protection. According to the result of this examination, which is conducted in accordance with civil procedure (sec. 50), the state either grants or denies its legal protection. The entire body of private law, whose elements (sec. 15) and whose system (secs. 16-36) were above outlined, therefore becomes the barrier and the

\footnotetext{
1 With reference to this and similar notions see sec. 14, supra.

${ }^{2}$ See supra, secs. $15-36$. Concerning claims in private law as legal powers to require of another an act, or a forbearance, see P. Langheineken, Anspruch und Einrede nach dem Deutschen B.G.B., Leipzig, 1903.
} 
premise of the state's activity, so far as it involves judicial administration. It is in the interest of the state, and as such is accepted and protected in its judicial administration, that private interests be protected according to the measure of their acknowledgment as private rights.

II. The state, however, in the practical execution of civil law does not limit itself to a decisional determination of controverted claims in private law. It also exerts a prudential administration of justice, ${ }^{1}$ for the security of private legal interests. This function of justice looks to the prevention of disputes, and to a security, stability, and conservation of claims (guaranteed interests) of private persons. This method of furthering justice is accordingly called "legal police," or more frequently non-contentious jurisdiction, and includes:-

1. Judicial care for the maintenance and carrying-out of inheritance rights in peaceable or non-contentious succession. To this end the office of inheritance authorities is established, which in the civil code is called the inheritance court (Nachlassgericht). This function requires a judicial inventory; a marking or deposit of the property of deceased persons; a judicial ascertainment of the heirs; and a peaceable distribution of the estate among the heirs; ${ }^{2}$

2. The institution of guardianship, and the direction, and supervision of guardians through guardianship courts (Vormundschaftsgerichte), see above, secs, 25, 29, $30,33)$;

3. The establishment and official direction of authenticating and attesting authorities (Beurkundungs- und

\footnotetext{
${ }^{1}$ See supra, sec. 48 , III, and the non-contentious jurisdiction statute.

${ }^{2}$ See supra, the substantive law of succession, secs. 34-36. On the inheritance or probate court see B.G.B., secs. 1945, 1960, Einf.G., art. 147, and the non-contentious jurisdiction statute, secs. 72-99.
} 
Beglaubigungsbehorden) by whom, or through whom, formal legal acts may be concluded or may be established. Such acts are agreements relating to land; and acts relating to other important matters, ${ }^{1}$ for example, wills. ${ }^{2}$ These functions attach either to the courts generally (which exercise in particular the power of confirmation of the more important private legal acts); or belong to special authorities.

Of such special authorities, are those official registrars who have the function of authenticating personal conditions and civii marriage ${ }^{3}$ registry officers whose official functions are necessary according to positive law in the transfer of land, ${ }^{4}$ the creation of hypothecary or other liens on land ${ }^{5}$ or on ships; ${ }^{6}$ the so-called local, intabulation, or registry courts ${ }^{7}$ (Orts-, Intabulierungs-, oder Protokollierungs-Gerichte) which sometimes exercise the functions of the land-registry, lien-registry, or the notarial office; and notarial officers who have authenticating functions ${ }^{8}$ which are exercised in foreign countries by consuls. ${ }^{9}$

4. Registry officers who are intrusted in the interest of the legal spheres of private persons with the public keeping of registers, rolls, or records, such as associa-

${ }^{1}$ Cf. B.G.B., sec. 313 (judicial or notarial authentication). See above, sec. 23 (contractual obligations). In certain cases non-contentious jurisdiction may embrace the taking of the oath of an insolvent with respect to his estate: the inspection and deposit of things; and the sale of pledges-noncontentious jurisdiction statute, secs. 163-166.

${ }^{2}$ See supra, sec. 36 , succession by will.

${ }^{3}$ See supra, sec. 26 ; non-contentious jur. st., secs. 69-71.

- See supra, sec. 20 ; cf. the land registry act.

s Sce supra, sec. 21.

${ }^{6}$ With reference to ship pledges see supra, sec. 21 , page 152 , notes 6,9 ; B.G.B., sec. 1259; non-contentious jur. st., sec. 100 .

${ }^{7}$ Thus the Amtsgericht [court of first instance] has jurisdiction to confirm agreements of adoption (see above, sec. 29) according to the non-contentious jur. st., secs. $65-68$.

${ }^{8} C f$. sec. 23; as to judicial and notarial authentication, see Einf.G.z. B.G.B. art. 141; non-contentious jurisdiction act, secs. 167-184.

${ }^{9}$ See infra, international law, sec. 55. 
tion, ${ }^{1}$ mercantile (firm, procuration), ${ }^{2}$ company, and corporation registers; $;^{3}$ matrimonial-property registers; $;^{4}$ useful models registers; ${ }^{5}$ and records for the entry of supplementary notification of anonymous, or pseudonymous published works of literature, music, ${ }^{\circ}$ etc.;

5. There may also be noted here, the official action of the imperial patent office, based on the patent act, ${ }^{7}$ in granting, as well as withdrawing and declaring void patents of invention, and in conferring protection for useful models; ${ }^{8}$

6. There may also be reckoned as belonging to the scope of non-contentious jurisdiction, the declaration of death of missing or lost physical persons, ${ }^{9}$ and the judicial nullification, or amortization of lost records; ${ }^{10}$

7. To a certain extent, the regulation of the property concerns of insolvent persons, in bankruptcy procedure, belongs to the sphere of non-contentious jurisdiction (sec. 50).

III. The operation of non-contentious jurisdiction, which is sometimes also called "preventive justice," is made of obligatory application by law, in many cases. This occurs partly in the sense that its operation is

1 See supra, sec. 15 , page 105 , note 2.

${ }^{2}$ Cf. sec. 58 (commercial law); H.G.B. of May 10, 1897, sec. 29, et seq.: non-contentious jur. st., secs. 125-158. Cf. supra, sec. 23, page 171, note 6 ; and infra. sec. 58 (commercial law).

3 See supra, sec. 23 (law of obligations), page 168 , notes 1 to 11 , also supra, sec. 15 , page 105 , note 2 .

${ }^{4}$ See supra, sec. 31 , note 1 ; B.G.B., secs. 1435, 1558-1563; non-contentious jur. st., secs. $161,162$.

5 R.G., Jan. 11, 1876 (Gareis, R.G., No. 13).

' Sec. 31, R.G., June 19,1901 , relating to authors' rights in works of literature, etc., see supra, sec. 18.

7 Statute of April 7, 1891 (Gareis, R.G., 122-123), sec. 13. See supra, sec. 18.

8 Useful models act of June 1, 1891 (Gareis, $R$ G., 122-123). See supra, sec. 18, V, 2.

B.G.B., secs. 13-20.

$10 \mathrm{Cf}$. law of obligations, sec. 23 ; with reference to the procedure of summons by publication sce civil procedure act, secs. 946-1024 (Gareis R.G., 227-234). 
directly enforced by regulatory punishment; as in the requirement of registration of firms. It occurs partly in that application to the state, in private legal claims, is not possible except through the proper use of the institutions of legal police (as in the case of requirements of land registry); in requirements relating to notarial authentication; in the standardized rules governing a registry, upon the compliance with which the existence of juristic personality, ' or a legal act, depends; the duty of making deposition for protection of models; ${ }^{2}$ and in applications for patents. ${ }^{3}$

1 See supra, sec. 15; B.G.B., sec. 55 (registered associations); noncontentious jur. st., secs. $159,160,162$.

2 See supra, sac. 18.

Sce supra, sec. 18. 


\section{SECTION 50}

\section{LAW OF CIVIL PROCEDURE}

It was pointed out above (sec. 15, IV), that one of the elements of private law is the protection of legal interests. This protection of a threatened or an infringed private right may, among other ways, be made effective by suit, or plea (Einrede) in civil procedure (sec. 15, IV , 2). Every legal rule, however, requires for its effectiveness as a standard,-no matter how established, or essentially declared,-the authority only of the state (as explained previously: sec. 8, I; sec. 9 (at end); sec. 10 (at end); sec. 11; sec. 12; also sec. 7, II). The operation of this authority, is manifested in the grant by the state of its protection in civil procedure.

When a legally protected, private interest or right (sec. 5) is violated or infringed, then the person vested with the interest may apply (sec. 49) to the dominant power which has promised its protection (which is the characteristic feature of a legal standard); and may require the concrete grant of this protection. The state thus applied to by complaint, will investigate whether the conditions exist upon which it, as the authority of the law, has promised to afford legal protection for the interest threatened or infringed. It will inquire whether the interest has been recognized as a legal advantage.

This preliminary investigation is conducted always by a method (procedere, Verfahren) ${ }^{1}$ called civil procedure (Zivilprozess). This procedure is a legal procedure. It is regulated by command and prohibition of the

1 Procedure may be taken as indicating a tegulated series of acts, intended to accomplish a definite, unified purpose. This is the sense in which the term is used, by way of example, in the German patent statute of May 25, 1877, and April 7, 1891, secs. 1, 4. Cf. Gareis, Das deutsche Patentgesetz (1877), p. 50. 
authority of the state. The fact that this procedure exists as such, and under legal regulation, accords with the interest of the state as a legal community. For this reason, the regulative standards of civil procedure are to be accounted as belonging to the domain of public law, state law and administrative state law (secs. 43, 48). The object of this procedure is the protection of threatened or violated interests seeking such protection, which protection is afforded necessarily by measures of force controlled by the state as an organized power. There is, however, no assumption of guaranty by the state of the proprietary or economic consequences of these measures. Nor is there any guaranty of exigibility in the complaint presented against violation or infringement.

Civil procedure, therefore, is that legal procedure which has for its object a grant of protection by the state in relation to a civil interest, made the basis of legal complaint, ${ }^{1}$ presented to the state; and the necessarily forcible grant of this protection in a controverted matter, involving the infringement of a legal interest which is recognized by the state as a legal advantage. Accordingly, civil procedure means the totality of legal standards through which this procedure becomes a legally regulated procedure.

The claim (Anspruch), complaint, which is the starting-point of civil procedure, is a claim on state protection for a private, legal interest. It is directed to the state, and is made effective by the courts-(sec. 48), the civil courts, courts of civil procedure. The court applied to for a grant of state help, ${ }^{2}$ on account of an imperiled or violated right, undertakes to inquire by procedure (specially designated as civil procedure)

1 On the basic conception relating to civil procedure, see Bülow, Degenkolb, Laband, Sohm, and Wach; cf. Gareis, Allg. Staatsrecht in Marquarden's Handbuch, p. 128, and Fr. Stein. Die Voraussetzungen des Rechtsschutzes, in the Hallenser Festschrift für Fitting (1903), particularly pp. 338, 339, also pp. 6, 7; contra J. Kohler in $Z$. f. deutschen Zivilprosess, Bd. 33. p. 211.

2 Thus Laband, Staatsrecht, sec. 84. Bd. III, pp. 349, 350. 
whether the premises of state law and private law exist upon which legal protection may be granted. It accordingly determines by a judgment whether the petition shall be granted or denied. The leading premises relating to public law are the competence of the court; and the dependence of the defendant on the might of the state applied to for protection. The premises appertaining to private law are the circumstances under which the interest asserted by the plaintiff, which is controverted, imperiled, disturbed, or infringed, is recognized in general as a legal advantage or as against the defendant. As to this the civil law determines (secs. 15-36).

The legal procedure which serves the judicial examination of these premises, is governed by established legal regulations ${ }^{1}$ which are closely connected with the organic law of the courts. ${ }^{2}$ Exclusive of procedure, they regulate the competence ${ }^{3}$ of the courts, the position of the parties, ${ }^{4}$ their representatives ${ }^{5}$ (Vertreter) and coun-

1 In Germany, apart from domestic provisions, these regulations arose chiefly under the influence of Roman. then Canon, and finally also French law. At the present time there is a unified enactment, due to imperial legislation, and arising especially out of the imperial civil procedure act. This act has been in force as a part of the imperial legislation relating to justice since Oct. 1, 1879, and became operative in a new form on Jan. 1, 1900, in accordance with an act of May 17, 1898, published by the chancellor on May 20, 1898 ( $R . G . B l ., 1898$, No. 25, p. 369; Gareis, R.G., 227-234). Commentaries on this act: L. Gaupp (3d ed. rev. by Fr. Stein, 1897-98); A. Förster and A. Engelmann (1902); Lothar Seuffert (8th ed., 1903); W. Endemann; Jul. Wilh. Planck, Bd. I, 1887; Bd. II, 1891, 1896; Adolph Wach, Bd. I, 1885 (in Binding's Systematisches Handbuch der Deutschen Rechtswissenschaft; Wach, Vorträge über die Reichszivilprozessordnung (2d ed., 1896); also the treatises of Friedrich Hellmann (1886), Richard Schmidt (1898) and Georg. Kleinfeller (1905); and finally, Friedrich Stein, Das Zivilprozessrecht in Birkmeyer's Enz., p. 923.

${ }^{2}$ Sec supra, sec. 48 , p. 258, note 2.

${ }^{3}$ Cf. supra, premises of state law, also Z.Pr.O.f. d. D. Reich, secs. 1-49.

${ }^{4}$ Plaintiff, defendant, capacity of parties (Z.Pr.O., secs. 50-58); joinder of parties (loc. cit., secs. 59-63); intervention of third parties (loc. cit., secs. 64-77); costs (secs. 91-107); security (secs. 108-113); forma pauperis (secs. 114-127). All sections according to the new revision and numbering.

${ }^{5}$ Attorneys and counsel (see $Z$.Pr.O., secs. 78-90); procedure conducted by attorney (Anwaltsprozess); the requirement of acting by attorney 
sel (Beistānde). This procedure is governed by highly important principles (I); is separated into various kinds of procedure (II); and has various divisions (III).

I. The following are fundamental principles of procedure:-

The initiative principles, nemo judex sine actore, and judex ne eat ultra petita partium; the judicial maxims, audiatur et altera pars, "eins mans red ist halbe red, man sol si billig hoeren beed," - not derogating, however, from the procedure in contumacy matters (Kontumazialverfahren). and the principle of affirmative litis contestatio, (the keeping of silence as to one's rights (cf.C. Pr. O. sec. 331)); the principle governing oral proceedings [quod non est actum (in procedure) non est in mundo]; the principle of immediacy [Unmittelbarkeit, requiring all the various steps in procedure to be conducted before the court]; the principle of unity [Einheitlichkeit, allowing new facts and proofs in oral procedure to be adduced until the end of the procedure in the Court of Appeals] with or without Eventualmaxime [rules to prevent delays in pleading, requiring timely defenses particularly in pleas]; and the principle of the public character of procedure (with certain statutory exceptions).

II. Of the different kinds of procedure, are to be distinguished the procedure in regular or general collegial and unitary courts, ${ }^{1}$ as well as other special kinds of procedure.

(Anwaltszwang) in matters before provincial and all higher courts (loc. cit., sec. 78): of. supra, sec. 48, page 257, notes 3,4 (attorneys, and the act relating to attorneys).

1 Concerning the historical aspect see A. Stōlzel, Die Entuickelung des gelehrten Richtertums in deutschen Landen (1872): cf. above, sec. 48 (organic court statute), and see civil procedure act, sec. 495 . compared with sec. 253. Another kind of courts is found in the trade courts according to $R$. G., Sept. 29, 1901 (Gareis, R.G., 115-116), and the commercial courts ( $R . G$. July 6, 1904); f. Gareis H.G.B. (1905), XXIX, XLIII). 
Of the special kinds of procedure, the civil procedure act recognizes: documentary and bills of exchange procedure (secs. 592-605); procedure in matrimonial property, the legal relations between parents and children, and emanicpation of minors (secs. 606-687); hortatory procedure (Mahnverfahren) (secs. 688-703); and a procedure in arbitration (schiedsrichterliches Verfahren) (secs. 1025-1048).

III. Of the different articulated divisions of procedure are to be noted:-

1. The initial process (Prozessinstruktion) and pleadings, oral (mündlich) or written (Schriftenwechsel). This begins with a complaint (Klage) which is followed by an answer (Klagbeantwortung). The answer may in whole, or in part (qualifiedly), be an admission, or denial (Leugnen); or it may set up grounds of objection (Einwendungen), which delay the process, or raise material exceptions (pleas, Einreden) to the complaint. The latter may be either dilatory or definitely conclusive, that is to say, they may be either dilatory or peremptory pleas, ${ }^{1}$ whereupon replication (Replik), rejoinder (Duplik), etc., may follow.

2. Procedure relating to proof (Beweisverfahren) with or without [an interlocutory judgment (Beweisinterlokut) establishing the thema probandum, onus probandi or dilatio probatoria], or decree of proof (Beweisdekret);

3. Judgment (Urteilsfällung);

4. Appellate procedure (Rechtsmittelverfahren);

5 . The procedure relating to execution, or the satisfaction of the judgment by force ${ }^{2}$ (Zwangsvollstreckungsverfahren).

${ }^{1}$ Langheineken, loc. cit. (sec. 49 supra, note 2), pp. 292-303, points out seventeen dilatory and twenty-six peremptory pleas as possible according to German civil law.

${ }^{2}$ With reference to the burden of proof, time of putting in proof, the form of oath, and related matters, see the learned discussions of Adolf Stölzel, "Schulung für die zivilistische Praxis," Berlin, 3d ed., 1898, pp. 79, et seq.; see also Langheineken, der Urteilsanspruch (1899). 
The system of evidence of the German civil procedure act attains its height in the provision allowing a free valuation of proof (sec. 286) in opposition to the socalled formal theories of evidence.

Remedies of appeal and error (Rechtsmittel) in the sense of the civil procedure act are: Appeal [Berufung: this appeal goes from the district courts (Amtsgerichte) ${ }^{1}$ to the general provincial courts (Landgerichte), and from the latter as courts of first instance to the civil senate of the provincial court of appeals (Oberlandsgericht); in this appeal questions of fact as well as law may be reviewed] (secs. 511-544); Revision [appeal from the court of appeals to the supreme court involving a summa revisibilis of 2500 marks (statute of June 5, 1905), and touching only questions of law] (secs. 545-566); and the Beschwerde [directed to other judgments than those re-examined by appeal and revision, as for example disciplinary punishment of parties, or even witnesses] (secs. 567-577): (without new pleadings; secs. 578-591). With reference to execution, see Z.P.O., secs. 711-945 and also R.G., March 24, 1897, concerning bankruptcy sales and other compulsory proceedings (Gar. R.G. 209210).

Administration of justice extends to the regulation of the property concerns of a debtor ${ }^{2}$ whose liabilities exceed his assets or which appear at least to be greater than his assets. The legal rules which govern the conditions and method of this protection of the private legal interests, as well of the creditor as the insolvent debtor, (bankrupt, insolvent), are called general bankruptcy law (Konkursrecht). This law severs into substantive bank-

"[Judge von Lewinski translates this "county courts." He says they are exactly analogous to English county courts. Dr. Otto Simon an attornev at Mannheim-on-Rhine (in an article in Green Bag. July. 1910) translates it "city or borough courts."]

${ }^{2}$ See supra sec. 22 (law of obligations). 
ruptcy law and into bankruptcy procedure. It has for its object the peaceable regulation ${ }^{1}$ of the colliding interests of creditor and debtor by the application, through peaceable measures, of the then existing assets of the debtor so far as susceptible to execution to the claims of creditors in conformity with the rules of bankruptcy.

The German bankruptcy act (Konkursordnung) of Feb. 10, 1877, is one of the four imperial judicature statutes which became effective Oct. 1, 1879. It became operative in a new form on Jan. 1, 1900, according to imperial act of May 18, 1898 (promulgated by the chancellor on May 20 of the same year) ${ }^{2}$. It legislates as well concerning the substantive law of bankruptcy (the administration of bankrupt estates and regulations governing claims against the bankrupt), as the procedure of bankruptcy (institution of proceedings, adjudication, discharge, etc.). ${ }^{3}$

\footnotetext{
${ }^{2}$ Friedrich Hellmann, Konkursrecht und Konkursprozess, in Birkmeyer's Enz., p. 1017; Lothar Seuffert, Das Konkursprozessrecht, Leipzig, 1899.

${ }^{2}$ R.G.Bl., 1898, No. 25, p. 612 (Gar. R.G. 235-237).

${ }^{3}$ Commentaries on the bankruptcy act; Volderndorff (2d ed., 1885); Sarwey (3d ed., revised by Bossert, 1895); Wilmowski (5th ed., 1896); Petersen and Kleinfeller (3d ed.); Stieglitz (1879); Lothar Seuffert (see note 1); H. Fitting, Lehrbuch (3d ed., 1899); J. Kohler (1891).
} 


\section{SECTION 51}

\section{CRIMINAL LAW}

The raising up of advantages of fact to legal advantages results, as has been pointed out, ${ }^{1}$ through the establishment of standards-commands and prohibitions. These standards whether declared by the state itself, or formulated by other agencies, ${ }^{2}$ are maintained and supported by the authority of the dominant governing entity, and are recognized as obligatory. These standards of human action operate on the faculties of perception, and by means of this, on the will of those persons who in their relations to others, are to be limited and protected by standard. They operate in such manner that motives are created to counteract egoistic impulses which tend against social life and the ends of society. ${ }^{3}$

${ }^{1}$ Secs. $2,5$.

${ }^{2}$ See supra, secs. 9, 10, 12. "Athens makes the claim of fame for its legislation, of a prodigious advance in the repression of private revenge. and in having placed it under the established legal power of the state."Lipsius, Leipziger Rektoratsrede (1893), p. 21. "State criminal law, however, was already known to the law of ancient Babylon in which the feud and Wergeld [mulct money] were not even suggested."-Kohler $u$. Peiser, Hammurabis G.B. (1904), p. 126 . With reference to Islamitic criminal law, see Kohler, Gerichtssal, Bd. 41.

3 See supra, sec. 7. The ancient law book of Manu describes in a very dramatic manner, the necessity of a state power over crimes, and the sharpening of motives for the protection of legal rights:-

"For the (king's) sake the Lord formerly created his own son, Punishment, the protector of all creatures (an incarnation of) the law. formed of Brahaman's glory."-Manu VII, 14.

- Punishment alone governs all created beings, punishment alone protects them, punishment watches over them while they sleep; the wise declare punishment (to be identical with) the law."-Manu VII, 18. Cf. also Julius Jolly, Recht und Sitte, p. 129.

"The whole world is kept in order by punishment, for a guiltless man is hard to find; through fear of punishment the whole world yields the en. joyments (which it owes)."-Manu VII, 22. 
The motives of human acts, created by legal order, stand alongside those evoked by custom, ${ }^{1}$ and morals, ${ }^{2}$ and frequently are supported by the latter. In the fulfillment of commands and in the observance of prohibitions, men are actuated (aside from religious or pure moralistic and like considerations) by the representation of the necessity and beneficient harmony of conforming to a general standard (the sense of order, the idea of justice, law and sociality). They are actuated by the representation of the necessity of security and order to the development of civilization; or they may be influenced by conceptions of acquisition, reward, good name, etc. In the same manner representations of legal injury, of liability, and of prejudice to reputation and credit, also operate on the minds of men in social life.

These ideas of the good and evil effects of conduct generate, or become motives, for the observance of standards; and for that reason the recognized relations of social life are protected by standard, as legal advantages. $^{3}$

To these motives, the state, as an organization of power, adds the new motive of punishment." When

"But where punishment with a black hue and red eyes stalks about, destroying sinners, there the subjects are not disturbed, provided that he who inflicts it discerns well."-Manu VII, 25.

"For when these creatures being without a king, through fear dispersed in all directions, the Lord created a king, for the protection of this whole (creation)."-Manu VII, 3.

"If the king did not, without tiring, inflict punishment on those worthy to be punished, the stronger would roast the weaker, like fish on a spit."Manu VII, 20.

"The crow would eat the sacrificial cake and the dog would lick the sacrificial viands, and ownership would not remain with any one; the lower ones would (usurp the place of) the higher ones."-Manu VII, 21.

'See supra, sec. 6 , IV, and sec. 2 , note 1, p. 5 , note 1, p. 7 , and note 2, p. 8 .

${ }^{2}$ See supra, sec. 6, II.

${ }^{3}$ See supra, sec. 5 .

4 This thought may give rise to doubt in various ways. The term "new," in the first place, is to be understood only as opposed to the motives previously mentioned. The state character of punishment and of criminal law in the discussion above is intentionally emphasized. There are punishments 
the motives generated by command and prohibition, or flowing directly and spontaneously therefrom, are not sufficient to operate on the perceptive faculties of men in such manner that a determined resolution arises not to infringe the legal advantage, legal right of another (whether an individual, or the community), then the governing social entity may authoritatively set up a new motive by a threat of evil as following such infringement. This occurs when it appears advisable to the state, to fortify or sharpen the motives favoring peaceable social existence in the interest of the protection of an otherwise insufficiently protected legal right. ${ }^{1}$ In the event of non-observance and violation of a legally protected interest, ${ }^{2}$ the threatened evil, in order that it may not be idle from the beginning, must be actually inflicted in cases of necessity; and this evil can only partake of an injury of a legal advantage (malum passionis propter malum actionis.)

Punishment is an intentional injury to a legal advantage of a delinquent, proceeding from the social will, for the protection of the legal advantages of other individuals of the community. Punishment may be leveled against or depend on cases where there is not yet present an infringement of a legal advantage. The law issues prohibitions and threats of punishment also

not of the state, and there is criminal law not of the statc, as in the case of canonical criminal law. A criminal law of the family is found antedating the criminal law of the state, - the jus vita ac necis of the paterfamilias, also the feud (family revenge), and collective revenge in general, as well as an ethically derived expiatory necessity. These factors operate even after the dominant community has assumed the creation of impulses of criminal punishment for the protection of standards; they influence the establishment of criminal law on the part of the state, and are in part, at least, the founda. tions, or starting-points, of public criminal law. See supra, sec. 8, especially note 3 , page 67 .

${ }^{1}$ Punishment as a social function. See v. Liszt, Lehrbuch des Strafrechts, sec. 3 .

${ }^{2}$ Cf. v. Liszt, Lehrbuch des Strafrechts, sec. 84, p. 289. 
against such acts as usually involve a peril to legal advantages. ${ }^{1}$

The purpose of punishment is protection of legal advantages, in general, and in particular. Threat of punishment, and visitation of punishment (the latter of which may and should have other objects than those indicated, as for example, reformation of the delinquent) do not create legal advantages. These advantages are created by a promotive standard through which conditions of fact are elevated to legally protected relations, to legally protected interests. Threat of punishment does, however, create a means for the security of the object which the standard strives for. It seeks to guarantee the observance of commands and prohibitions, not directly, but indirectly; and thereby to protect interests.

The method by which this result is to be attained, it is apparent, is a legal method, operating by means of commands and prohibitions. The primitive method, out of which the feud and every other kind of collective revenge arose, was to place the person who had infringed a legal advantage beyond the pale of protection of legal advantage; either by subduing him by actual force, by exercising physical compulsion over him and thereby pacifying him; or by expelling him beyond the community of law, by surrendering him up as one outlawed, and beyond the reign of law; with the most ferocious consequences in either case.

With the growth of the notion of law, this impulse of society to destroy the criminal passed into the background. The legally dominant community operating by means of command and prohibition in the protection so far as possible of personality and its rights (even, as to delinquents), substituted for these primitive tenden-

1 Binding, Die Normen, I, 47; Handbuch, I, 170. 
cies which involved the annihilation of the criminal, legal limitations by the establishment of criminal legislation, and the recognition of a criminal law. Out of this development arose the right of punishment on the part of the state, as the legally recognized interest of the state as the bearer of state power, to revenge violations or injuries of legal advantages with certain injuries to legal advantages. This interest is one legally recognized; but it is also one legally limited by the recognition of the interest of the state, that the personality of the criminal is not to be subjected to excessive corrective punishment.

Binding is in agreement with this thought when he says: "Criminal legislation is a legitimate measure, and is in fact the establishment and standardization of the legal relation between the criminal authorities and the delinquent."1

The totality of legal rules upon which rights relating to crime are based, and the legal standards by which certain acts are threatened with punishment under the application and direction of the state, forms the so-called substantive law of crimes. It is that part of state law which frequently is called criminal law.

Criminal legislation and the science of criminal law deal in general and in particular with the objective and subjective conditions of criminal acts (matters of fact, attribution, etc.); with the kinds of punishment and punishable violations of legal rights (delicts, either crimes in the narrow sense, Verbrechen [punishable by death, or imprisonment exceeding five years], Vergehen [punishable by fine exceeding 150 marks, or imprisonment up to five years], or Übertretungen [offenses punished by

${ }^{1}$ Binding, Handbuch, I, sec. 38, p. 191. 
arrest and fine up to 150 marks]); and with the relation between offense and punishment. ${ }^{1}$

The criminal law of Germany was first extensively codified in the penal code of King Charles V (constitutio criminalis carolina) in $1532 .^{2}$ At the present time there is in force in Germany, the criminal code of May 15, 1871 (amplified Feb. 26, 1876), ${ }^{3}$ whose separate parts are as follows: introduction (secs. 1-12); Part First: the punishment of crimes and misdemeanors (secs. 1342), attempts (secs. 43-46), accessories, etc. (secs. 4750 ), grounds of withholding or extenuation of punishment (secs. 51-72), plurality of criminal acts (secs. 7379) ; Second Part: particular crimes and misdemeanors, and their punishment: high treason (secs. 80-93), injuries to the sovereign (secs. 94-97), injuries to the imperial princes (secs. 98-101), hostile acts against friendly states (secs. 102-104), crimes and offenses against the execution of civil law (secs. 105-109), resist-

1 The following were primitive principles concerning the relation between delict and punishment: the fundamental rule of simple retaliation

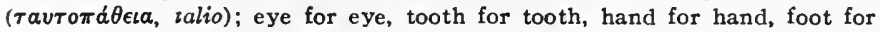
foot, burning for burning, wound for wound, stripe for stripe, life for life. -Mos. ii, 21, 24-25; Mos. iii, 24, 17-21; Mos. v, 19, 21 (cf. Matthew v, 38); Code of Hammurabi, secs. 196-200.

On the other hand, the fundamental proposition that that part of the body is subject to punishment by means of which the delict was accomplished as in the ancient Indian law:-

"With whatever limb a thief in any way commits (an offense) against men, even of that (the king) shall deprive him in order to prevent (a repetition of the crime)."-Manu VII, 334. Cf. Julius Jolly, Recht u. Sitte, p. 130; cf. Code of Hammurabi, sec. 195: "When a son shall strike his father, his hands shall be cut off."

${ }^{2}$ See also supra, sec 11.

${ }^{3}$ Commentaries: v. Oppenhoff, Rüdorff, Olshausen, v. Schwarze, Stenglein. Meyer, Rubo, Reinhard Frank. Literature: v. Holtzendorff's Handbuch d. deutschen Strafrechts in Einzelbeiträgen; Binding, op. cit.; v. Liszt, Lehrbuch des deutschen Strafrechts, 10th ed., 1900. In place of all other literature, there may be indicated: Die Strafgesetzgebung der Gegenwart in rechtsvergleichender Darstellung by Fr. v. Liszt and Gg. Crusen with the co-operation of many other writers; R. Finger, Lehrb. d. D. Strafrechts; Karl Birkmeyer, Das Strafrecht in Birkmeyer's Enz., p. 1095: Karl Birkmeyer, Das Militärs'rafrecht, loc, cit., p. 1203. 
ance to public authority (secs. 110-122), crimes and offenses against public order (secs. 123-145a), counterfeiting and coinage offenses (secs. 146-152), perjury (secs. 153-163), false accusation (secs. 164-165), offenses against religion (secs. 166-168), crimes and offenses against the status of persons (secs. 169-170), crimes and offenses against morals (secs. 171-184), affronts (secs. 185-200), dueling (secs. 201-210), crimes and offenses against life (secs. 211-222), corporal injury (secs. 22:3233), crimes and offenses against personal freedom (secs. 234-241), theft and embezzlement (secs. 242-248), robbery and extortion (secs. 249-256), encouragement of theft and concealment of stolen property (secs. 25i262), fraud and deceit (secs. 263-266), falsification of records (secs. 267-280), crimes in bankruptcy (Bankruptcy act, secs. 239-244), penal self-seeking and violations of the secrets of others (secs. 284-302), injuries to things (secs. 303-305), crimes and offenses arising out of acts perilous to the community (secs. 306-330), crimes and offenses in public office (sees. 331-359), lesser offenses (Übertretungen), secs. 360-370). (See Gareis, Reichsgesetze, Nos. 143-146). 


\section{SECTION 52}

\section{CRIMINAL PROCEDURE}

The infliction of punishment is the visitation of an injury to the legal advantages ${ }^{1}$ of the person punished by the reproving state. Such impairment of legal advantage, however, requires a definite rule permitting such injury, in order that it may not itself become illegal, where the entity receiving punishment is a person, and as such is protected in his legal advantages. The allowable rule employed by the state in its punitive capacity and involved in the infliction of injury to legal advantages by way of punishment, is the concrete standard of criminal law.

It is through this standard that the interest appertaining to the state in the infliction of injury to legal advantages (malum passionis) becomes legally guaranteed: that is, becomes limited, recognized, and secured by means of commands and prohibitions. Accordingly, there arises a penal interest in a legally circumscribed punitive claim (Strafanspruch) which belongs to the bearer of criminal jurisdiction over delinquents. In earlier times this jurisdiction, as far as it extended to include graver offenses, was called Blutbann [cause sanguinis].

This punitive claim is also a claim against the bearer of the means by which the proper punishment shall be inflicted on such delinquents. The bearer of these means is the state. When the state by virtue of its character as a legal community, feels that it has sus-

\footnotetext{
1 Injury to the legal advantage of personal frecdom (imprisonment); of ownership (fines); and of life (the death penalty.j etc.
} 
tained a social injury by the commission of a crime, it makes a penal claim based on the substantive criminal law (sec. 51) directed against the delinquent and against the state as the bearer of the agency of punishment. ${ }^{2}$ It requires, to alter the expression, that the state as an organization of force and the governing entity which makes provision against delinquents in a substantive law of crimes, shall inflict a threatened evil (malum passionis).

In order, however, that such injury to one's legal advantages may follow, the state, as an organization of force which can not disclaim its nature as a legal entity, nor its character as the protective instrument of rights,even those of the person accused-sets up a condition against the expectation of punishment raised by formal complaint. This condition is the necessity of proof, and it requires the existence of such a case (malum actionis) as entitles and obliges the state within the scope of legal order (the substantive law of crimes) to protect legal advantages by means of legal injury. This postulate of proof is based on the totality of conditions of penal culpability governed by concrete matters of subjective and objective fact. It is to be met in such manner, that the greatest possible security may exist that no innocent person may suffer a deprivation of legal advantage, and that no illegal or excessive injury shall be inflicted on the guilty.

Accordingly, there is necessary to such proof, a suitably regulated series of acts, a procedure, ${ }^{2}$ which is called criminal or penal procedure. This procedure is one legally regulated, as is the case in the determination of matters of civil complaint (sec. 50). The legal regula-

\footnotetext{
1 The state as the dominant social entity possesses all the agencies of power necessary to punitive execution (deprivation of legal advantages). This follows from the dominion, the sovereignty of the state. Sec supra, sec. 46.

2 The conception "procedure," see supra, sec. 50 , note 1.
} 
tion of this procedure-the totality of legal standards for the determination of concrete criminal complaints, and the confirmatory or non-confirmatory decision by which there is legally guaranteed whether the requirements of proof of criminal culpability have been metis called criminal procedure. In analogy to civil procedure, the function of criminal procedure is legally to limit and to protect the interest of the state as a legal entity, by means of commands and prohibitions, in order that the power of the state may not be applied or refused inconsistently with legal order in the protection of legal advantages. ${ }^{1}$

Criminal procedure is connected with the organic constitution of courts. The answer in concreto to the question whether a particular criminal accusation is well founded lies with independent officers, the courts, ${ }^{2}$ the criminal courts, who are limited only by law, in the judicial judgment-the pronouncement of guilt or innocence.

The kinds of courts are distinguished in general as learned courts (Gelehrtengerichte), popular courts (Volksgerichte), and mixed courts. Mixed courts may be consolidated courts, such as assessor's courts (Schöffengerichte), or combined as in the case of juries (Schwurgerichte). This touches a much discussed subject. (The kinds of courts as they now exist in the German Empire are enumerated in sec. 48 , p. 258 , note 2 ).

Criminal procedure is governed also by various important principles, among which may be mentioned chiefly, on one hand, the inquisitorial principle (Untersuchungsprinzip), and on the other hand, the accusatory prin-

\footnotetext{
${ }^{1}$ Cf. v. Liszt, Lehrbuch d. deutschen Strafrechts, 10th ed., 1900, p. 20, also the controversies regarding criminal law, id., sec. 16, p. 66 . See further the !iterature noted at sec. 50 , note 1 , page 266 , supra.

${ }^{2}$ See supra, sec. 48; on the historical side, see the work of A. Stölzel noted at sec. 50 , p. 268 , note 1 , supra.
} 
ciple (Anklagsprinzip), or a combination of both. The fundamental principles of the oral and public character of this procedure, both with exceptions, may also be noted, according to which the different kinds of procedure are distinguished. ${ }^{1}$ In the procedure of accusation, according to the accusatory principle, the office of the public prosecutor plays an important part. (See sec. 48).

The parts into which criminal procedure is divided are the initial procedure (preliminary procedure, preliminary examination, general inquisition); procedure in chief (in a certain sense coincident with what was at one time called special inquisition, consisting principally of the production of evidence, criminal complaint (Anklage), defense, and pronouncement of judgment); and appellate procedure and punishment.

The German criminal procedure act of Feb. 1, 1877, which is one of the judicature statutes which since Oct. 1, 1879, has been in effect for the whole empire, embraces: First book: general provisions: the essential competence of criminal courts (secs. 1-6), the jurisdiction of the courts (secs. 7-21), exclusion and rejection of judges (secs. 22-32), judicial decisions and their promulgation (secs. 33-41), limitations and re-instatement of former position (secs. 42-47), witnesses (secs. 48-71), expert and eye witnesses (secs. 72-93), search and seizure (secs. 94-111), arrest and provisional detention (secs. 112-132), examination of the accused (secs. 133136), defense (secs. 137-150); Second book: (preliminary procedure): public accusation (secs. 151-155), prepara-

\footnotetext{
${ }^{1}$ Cf. sec. 50, II, supra.

${ }^{2}$ Gareis, R.G., 125-130: M. Stenglein. Lehrbuch des deutschen Strafprozessrechts, 1887: K. Binding Grundriss des deutschen Strafprozessrechts, 4th ed., 1899; Karl v. Lilienthal, Das Strafprozessrecht, in Birkmeyer's Ens., p. 1233 and literature there noted; Lilienthal, Das Militarstrafgerichisveriahren, in Birkmeyer's Ens., p. 1309.
} 
tion of the accusation (secs. 156-175), preliminary judicial examination (secs. 176-195), decision regarding the opening of chief procedure (secs. 196-211), preparation for chief procedure (secs. 212-224), chief procedure (secs. 225-275), procedure in chief with jury (secs. 276-317), procedure relating to absent persons (secs. 318-337). Third book (appellate procedure): general provisions (secs. 338-345), complaint-review (Beschwerde) (secs. 346-353), appeal (Berufung) (secs. 354-373), revision (secs. 374-398) ; Fourth book: re-instatement of adjudicated cases (secs. 399-413); Fifth book: (participation of aggrieved persons in procedure): private complaints (secs. 414-434), collateral complaints (secs. 435-446); Sixth book: (varieties of procedure): procedure in inferior courts (secs. 447-452), preliminary police control (secs. 453-458), procedure relating to acts contravening statutes for raising public taxes and revenues (secs. 459-469), procedure relating to absentees who have avoided military duties (secs. 470-476), forfeiture and confiscation of property (secs. 477-480); Seventh book: (execution and costs): execution (secs. 481-495), and costs (secs. 496-506). 


\section{SECTION 53}

\section{ADMINISTRATIVE JURISDICTION}

As has been repeatedly pointed out, the state in the administration of its sovereign rights is bound by legal rules. Standards on one hand protect the interest of state administration, and on the other hand they limit it in the interest of persons within the state. These persons possess spheres of interest of their own, which are recognized by positive law as legal spheres.

A conflict is always conceivable between the spheres of interest of the individual and the interest spheres of the state, in administration. There must, therefore, exist some arrangement within the state for a determination of such cases of collision. Forasmuch as this determination involves a decision, that is of a legal conflict or controversy, between the right of the state in its administration (administration of soyereign rights ${ }^{1}$ ), and the right of an individual or a corporation, a legal controversy arises. Decision of such controversy is possible and allowable only according to a legally regulated procedure and pursuant to authoritative and substantive legal standards.

The same may be said of controversies between individuals or corporations regarding interests protected by

\footnotetext{
"Both "administration" and "sovereign right" are to be emphasized. Administration only and not legislation can come to such a conflict. Legislation stands imperatively above the supposed legal spheres in conflict. nullifying or validating rights, and is not subject to decision. This is characteristic of the sovereign legislation of the state. Only the administration of a sovereign ight may lead to a legal administrative controversy. The administration of such legal advantages as may also appertain to private persons, individuals, or associations (as chiefly in the administration of property) is subject to decision by civil procedure. The state conforms to the latter procedure in its capacity of fiscus.
} 
public law; in other words regarding rights and duties which spring out of public interests. Decision of these cases which is possible only as based on positive external law in a legally ordered procedure, is carved out of the standards of public law. Inasmuch as public law is also the source of decision in conflicts between legally guaranteed spheres of state administration of sovereign rights, and the spheres of private persons, therefore both classes of conflict may be united under the name "controversy of administrative law" dependent on "administrative justice" which is also called "administrative jurisdiction" (see sec. $48, \mathrm{~V}$ ).

The exercise of this jurisdiction devolves on administrative courts in a procedure which is called the procedure of administrative controversies, or simply administrative procedure (Administrativprozess). Every administrative controversy is grounded on a claim against the state, which invokes its protection in analogy to claims in civil procedure (sec. 50). The plaintiff in an administrative controversy asks of the state, as the bearer of state power-as well also as when the state as an individual is the defendant-protection of a public and legally recognized interest which has been violated in the administration of a sovereign right of the state, or that of a private person. The state, however, which is applied to as an organization of force may, in that it is a legal agency, afford the required protection, only on the condition that it is established by proof that the defendant-the state, or an individual - has infringed a public and legally protected interest of the plaintiff. ${ }^{1}$

\footnotetext{
1 The above conception of administrative controversies is treated in detail by Gareis, Allg. Staatsrecht, in Marquardsen's Handbuch des offentl. Rechts, Bd. I. p. 127. See also R. Gneist, Rechtsstaat, 2d. ed. (1879), pp. 267-277; O. v. Sarwey, Das öffentliche Recht und die Verwaltungspflege (Tübingen, 1880), p. 4; v. Pözl, in the Oesterr. Zeitschr. für Gesetzgebung und Rechtsprechung auf dem Gebiete der Verwaltungspflege, Bd. II (1878), p. 318; Hermann Schulze, Lehrbuch des deutschen Stautsrechts, I, sec. 230, p. 640:
} 
The courts invested with jurisdiction over administrative law are frequently (at least in the case of inferior courts) connected with the official administrative organization, or with the local government, local districts, of the state. In the higher courts, as in the administrative court, and in superior and supreme courts of administrative jurisdiction, these officials of justice are generally separate from this administrative organization. The procedure in administrative law is modeled in general, with modifications, after civil procedure, with variations of form in different states, in accordance with the diverse range of legal cases which are subject to decision in administrative jurisdiction.

Jolly, in the Tübinger Zeitschr. f. d. ges. Staatswissenschaft (1878), pp. 476-506; $\mathrm{Gg}$. Meyer, Lehrb. d. deutschen Verwaltungsrechts, I (1883), sec. 9, p. 28 (and literature noted); Dr. Ludwig von Rönne, Das Staatsrecht der Preussichen Monarchie (5th ed. rev. by Dr. Philipp Zorn), Bd. I (1899), p. 530; Max Seydel, Grundzüge einer allgemeinen Staatslehre (1873), pp. 76-99; Seydel, Bayerisches Stcatsrecht, Bd. I-VII (1884-1894); Hue de Grais, Handbuch der Verfassung und Verwaltung in Preussen (11th ed., 1897); Dietz-Küchler, Die Verwaltungsgesetzgebung des Grossh. Hessen., 2 vols. $(1885,1886)$; Gareis, in the Oesterr. Zeitschr. f. Gesetzgebung und Rechtsprechung auf dem Gebiete der Verualtungsrechtspflege, Bd. II (1878), pp. 472-476; Gareis, in Handb. des offentl. Rechts, allgem. Staatsrecht (1883), pp. 129, 130; Adolph Arndt, Von den Kontrollen der Verwaltung, in Birkmeyer's Enz. (1904), pp. 917-922, in which the most recent establishment of administrative judicature, that of the kingdom of Saxony (act of July 19, 1900) is discussed (p. 922). 
[SECOND DIVISION OF PUBLIC LAW]

\section{INTERNATIONAL LAW}

\section{SECTION 54}

\section{THE NOTION, SIGNIFICATION AND SOURCES OF INTERNATIONAL LAW}

According to the distinction made above (secs. 14, 37, 38) public law embraces international law $^{1}$ and state law.

International law is the totality of legal rules by which the public interests of states among themselvesthe international relations of states-are legally governed by legal duties and legal rights; and accordingly by which the common interests of states are legally protected.

The sources of this indispensable though imperfect peaceable adjustment among states are custom (therefore customary law) ${ }^{2}$ and legal necessity (accordingly

1 The literature of international law begins with Hugo Grotius, De jure belli ac pacis (libri tres, Paris, 1625). The principal works in the German literature are: Heffter, Das europäische Völkerrecht der Gegenwart, 7 th ed. rev. by H. Geffcken, 1881; Bluntschli, Das moderne Völkerrecht der zivilisierten Staaten, 1872; v. Holtzendorff, Enz. der Rechtswissenschaft (systemat. Teil); Völkerrecht, in Handbuch des öffentl. Rechts (1884), Bd. I (rewritten in the 2d ed. of this publication by E. Ullmann (Munich, 1898), Bd. I, II, 2, (XI); v. Martens, Völkerrecht (1883); Fr. v. Holtzendorff, Handbuch des Völkerrechts, Bd. I (1885), Bd. II, III (1887); Franz von Liszt, Das Völkerrecht, Berlin, 1898 (see sec. 4, p. 18 for literature); Alphons Rivier, Lehrbuch des Volkerrechts (1889), and Principes du droit internationale (1896); Stoerk, in Holtzendorff's Rechtsenzyklopädie, 5th ed.; F. von Martens, International Law (Ger. by Bergbohm, 1883-1888); Gareis, Institutionen des Völkerrechts, $2 d$ ed., 1901, sec. 11; Augusto Pierantoni, Die Fortschritte des Völkerrechts im XIX Jahrhundert (Ger. by Fr. Scholz, Berlin, 1899); Gareis, Die Fortschritte des internationalen Rechts im letzten Menschenalter; Franz v. Liszt, Das Völkerrecht, in Birkmeyer's Enz., p. 1345, and literature there noted.

${ }^{2}$ See supra, sec. 10. 
jus necessarium)." International agreements (conventional law) are subordinate to both of these sources, but are a very prolific source of international standards.

The imperfection in the adjustment of international peace lies in the fact that necessarily there is wanting a legislative, directing and judicially compelling authority over the states by which the standards of international law may imitate the power exercised by the state in the government of public and private legal relations within the state. This deficiency in international law does not, however, extend to a point where the existence of international law must be denied. ${ }^{2}$

The ancient state already had acknowledged the authority of international law; and commerce with and among barbaric peoples was not wanting in international standards which were brought about by anticipated advantages of reciprocity as well as by fear of retaliation. Legal rules are observed, and legal duties are recognized and respected ${ }^{3}$ even in the extremest violence of state against state in war. The normal condition of states in their relation to each other is one of peace. The exalted purpose of international law is the legal maintenance of this peace; the protection, cultivation and furtherance of the common interests of the states by peace; and therefore the guaranty of the prerequisite conditions necessary to an unhindered cultural evolution within each state.

'See supra, secs. 9, 12, (Rechtsnotuendigkeit = Jural necessity.)

${ }^{2}$ Cf. Gareis, Inst. des Volkerrechts, sec. 2, and literature noted; Stoerk, in J.L.B. v. K., Heft 9.

See Gareis, Genfer Konvention (Giessen, Emil Roth, 1895).

- As to the relation of German politics to this aspect of inter national law, in connection with the maintenance of a world peace, and the furtherance of the common interests of civilized states, see Gareis, Inst. des Volkerrechts (1902), sec. 7, p. 24 ; sec. 8, pp. 24, 25, 29. 


\section{SECTION 55}

\section{SYSTEMATIC SURVEY OF THE CONTENT OF INTERNATIONAL LAW}

In order to arrive at a clear exposition of the content of international legal standards, it is necessary to proceed from the fact that a community of interests among states exists and is recognized; and that legal standards are adopted for the protection of these interests. A review of the genesis and nature of these protected interests is the chief thing for discussion, in consonance with these principles of international law.

This discussion is found in treatises on international law, and as a rule in the prelininary or general part of these works. The treatment requires a consideration of the holders (Inhaber) of the common interests whose protection is the object of international law; that is to say, the subjects of international law-the states. It also requires consideration of the objects of these interests; that is to say the connections of fact (Beziehungen) and things of international law. Finally the origin, alteration and abrogation of protected interests are to be treated.

The so-called "general part" of international law is followed by an exposition of protected special interests. These special interests may be approached in a twofold direction. On the one hand, according to their content (matter, material). In this case specially protected interests are treated as real, or material in the so-called substantive part of international law.

In another direction, consideration may fall on the kind of measures. The aim of these measures, when it becomes necessary to employ them, is the protection of 
interests. These measures are employed when interests come into conflict. This division may be designated as the procedural or formal part of international law. It naturally severs into two subdivisions in accordance with the fact as to whether the measures employed are peaceable or involve the use of force.

Substantive international law therefore embraces:-

1. The legal rules for the protection of the primary or elementary interests of the state-the so-called fundamental rights of states-generally distinguished as of four kinds;

2. The international legal interests of heads of states, including non-sovereign, as well as sovereign heads;

3. The international legal interests of officers (the authorities of international law, including principally the international legal position of envoys of which there are four classes according to rank; and of consuls of which there are two chief classes: commercial and jurisdictional consuls; ${ }^{1}$

4. The international interests of subjects of the state so far as applicable; that is, so far as states have legal duties toward such subjects;

5. International interests in the state domain, or more accurately stated, the international regulation and protection of the interests of states in their territory.

Substantive international law including these five different groups is susceptible of and even requires another group based on the sources of international law. It accordingly embraces a consideration of the authoritative scope of the rules flowing therefrom.

These legal rules are to be considered as abstract rules of international law, derived ex lege, as it were, springing from customary law, and the necessity of law (Rechtsnotwendigkeit); and are to be treated as the commonly authoritative, general, and necessary international law.

${ }^{\prime} C f$. Liszt, V.R., sec. 15. 
Interests may, however, be regulated in relations between two or more states under special arrangements different from the general rules of international law. States may define and guarantee the interests common to themselves otherwise than by the general rules of custom and jural necessity; but only to the extent that principles of international law which are lex cogens are not departed from. There is, therefore, a special or conventional international law, and there are special rights and duties of states arising from international agreement. Accordingly, in each of the five groups of interests, and the legal institutions protecting them, there are operative two kinds of legal standards. On one side these standards are those of jus necessarium and jus consuetudinarium; and on the other those of $j u s$ voluntarium (voluntary law, special law, law arising from agreement).

In the procedural or formal part of international law, the principal treatment relates to the so-called laws of war: $(a)$ the rules for the conduct of war, and $(b)$ causes or grounds of war embracing legal rules concerning subjects, objects and agencies of war. This part also includes the law of neutrality, and the law governing the conclusion of peace. 


\section{SUPPLEMENT TO PRIVATE AND PUBLIC LAW}

[Supplementing Sections 14-55]

\section{SPECIAL LAW OF PROFESSION AND POSITION}

\section{SECTION 56}

\section{SPECIAL LAW, GENERAL PART}

In the exposition and survey of legal standards, the system of law, as hereinabove considered, is derived from the essential nature of law (the protection of interests). It is based on the differences in the holders of interests (public and private interests), and derived from variations in the objects of interests (things, personal relations, or duties in private law, sovereign rights in public law, etc.). This system may, however, be abandoned.

In the treatment and arrangement of legal rules, another viewpoint may be taken. The classification of standards may be varied by a difference in their coordination. Other relations and different contrasts will appear by this change than in the system derived from the conception of rights and interests (see sec. 14).

Didactic and practical considerations may suggest themselves in such variation of standpoint. It is possible that a concrete theory might regard it as desirable to arrange legal rules in another order than the system based on the notion of rights requires. Considerations of practical life may possibly also lead to a system of classification easier of approach and application from the standpoint of practical men.

Accordingly those legal rules which relate to the members of a special station in society, whether by 
reason of birth, or occupation, or on account of membership in a particular association or corporation, may be arranged in a special co-ordination; and as such be treated with or without regard to what position these legal rules may have in the system considered (secs. 14-55). So-called special laws, such as laws of profession, of social position, and including the law of corporations, are developed from such standpoints.

Considered from the viewpoint of a special legal position flowing from birth, the exposition of the law of nobility ${ }^{1}$ allows of a more striking and obvious development in a special department than is possible in treatment of the same matter in connection with the bulk of the system. The material of this special law illustrates the point: for example, the privileges of nobles in public law, the peculiarities of family law governing the higher nobility, ancestral property, and the related rights of inheritance, etc.

In a similar manner the presentation of feudal $\mathrm{law}^{2}$ is that of a kind of special law, derived in part from interests of position, and in part from interests of special private law (sec. 21, 3, supra).

A prolific classification of private and public legal standards is afforded by the standpoint of different economic activities.

By way of illustration, the totality of legal rules of international law, ${ }^{3}$ state $1 \mathrm{law}^{4}$ and private law $^{5}$ relating to forestry, the control of forests and the forest police may be grouped and treated as a so-called law of

${ }^{1}$ Cf. Gg. Beseler, System des gemeinen deutschen Privatrechts, 3d ed., secs. 168-176; H. v. Schulze-Găvernitz, Das deutsche Fürstenrecht, in Holtzen dorff's Enz., 5th ed., p. 1349; Hermann Rehm, Modernes Fürstenrecht (1904).

${ }^{2}$ Beseler, op. cit., secs. 147-167; see infra, sec. 57, note 2 .

3 The provisions relating to wood tolls (Holzzölle) in international agreements.

- Forest-police commands and prohibitions, the fundamental rules relating to state management of forest domains.

${ }^{5}$ Provisions relating to forest servitudes, usufructuary forest rights. 
forestry. The same may be said of the related provisions of jus publicum and jus privatum concerning hunting, fishery, mining, agriculture and colonies. It follows that the subject-matter of the law of hunting, fishery, mining law, law of agriculture, ${ }^{1}$ and the law of colonies, ${ }^{2}$ etc., may be treated as varieties of special law.

In the development and exposition of these and other classes of special law a double aspect is possible. Such special law may include only those legal rules peculiar and singular to the position or occupation under consideration. This is special law in a narrow and technical sense. It may embrace also such legal rules of the residuum of private or state law as are not distinctive of the particular occupation or position; but which the persons of such position, or occupation, must be familiar with in order properly to develop the interests of such special station or employment. ${ }^{3}$

It is apparent that in the demarcation of such special law in the wider sense, scientific treatment may include for exposition a greater or less quantity of related material of public and private law. This is also true of theoretical treatment of special legal departments, embracing industrial, commercial, or similar groups of activities. Thus a law relating to industrial pursuits, ${ }^{4}$ a law of manufacture, a law of commerce, ${ }^{5}$ postal law, railroad law, ${ }^{\circ}$ military law, ${ }^{7}$ bourse law, insurance law, etc., may embrace all those standards of state and private law which relate to the activity or station under consideration, either specially or by implication.

1 C. Beseler, op. cit., secs. 177-179.

${ }^{2}$ Cf. Gareis, Deutsches Kolonialrecht, 2d ed. (Giessen, Roth, 1900.)

3 This viewpoint touches the law of forestry and the law of agriculture in a special and conclusive way.

Beseler, op. cit.. secs. 210-213.

5 See below, sec. 58.

- Cf. Endemann, Das Eisenbahnrecht (1887).

7 This would include military criminal law. Sec Birkmeyer's Enz., p. 1203. 
That variety of legal standards which govern the legal relations of associations and corporations among themselves and which refer to the relations of their members as such among themselves, and to such associations, may also in like manner be consolidated as a special totality of rules.

This unification becomes all the more important in proportion to the greater social end to be attained, and in accordance with the influence of such associations on social life, and the advance of civilization. An importance, possibly, attaches also on account of the influence of such organizations on the form of the law itself. An influence on the form of the law is exerted by such associations as exercise an autonomy and have an independence in the creation of the standards for their legal relations (secs. 9, 12b, 15).

In religious associations all these influences have combined to create a law, church law, encompassed by a special importance. In past centuries, in fact, the importance of this law extended so far that a twofold division of the entire legal system resulted: the jus civile (ccesareum, seculare or profanum), and the $j u s$ canonicum (ecclesiasticum, or pontificium). ${ }^{1}$

Church law and commercial law are subjects of special treatment by reason of their historical and practical importance; as well also on account of their extensive legislative and theoretical development as special departments of law; and because of their historical acceptance as special departments of juridical study and learning (secs. 57, 58).

\footnotetext{
1 Therefore the title, "doctor juris utriusque." With reference to the meaning of jus canonicum, see sec. 57, infra, page 297, note 3 .
} 


\section{SECTION 57}

\section{CHURCH LAW}

Church law is the totality of legal principles ${ }^{1}$ by which those religious societies called churches are legally regulated as external and tangible associations. ${ }^{2}$ Church law involves state law and private law in so far as these legal principles are based in part on interests of the dominant community, in part on the interests of churchly associations themselves, and in part on the interests of their members.

Examples of standards of public law are those concerning the placetum regium, the penal provisions for the protection of the legal spheres of churches, certain special reserved rights of ratification, state standards of supervision, etc. Standards of private ${ } \mathrm{w}^{3}$ are such as govern the internal organization of church associations, the administration of church property, etc.

With respect to their sources (in so far as the standards of church law are established by the state) they are state standards, laws in the ordinary and substantive sense of the word. This is so whether they protect state or church interests; and accordingly whether, as to their content and form, they are the material of state law on one side, or church association (and therefore private) law, on the other.

Such standards of the state, however, form the least important part of the historically derived church law

${ }^{1}$ Church law as special law. See sec. 56 (end).

2 Concerning this notion sec Hinschius, in Holtzendorff's Enz., sec. 2; and v. Schulte, Lehrbuch des kathol. und evangel. Kirchenrechts (4th ed. on Catholic Church law, and 1st ed. on Luthe1an church lax, 1886), sec. 2 and literature entered.

${ }^{3}$ In this aspect, churches are considered as juristic persons. See supra, sec. 15, No. 1; cf. also sec. 23 , III, No. 5 (end). 
of the Catholic Church. The internal power of the church has developed a large number of standards which prevail as the proper autonomous law of the church (secs. 9,12 ); to the extent that the state has not denied them its legal recognition and sovereign authority. ${ }^{1}$ The rules created in this way by autonomous church legislation as well as the effective customary rules prevailing within the scope of the church (that is the statutory law and the law of observance of the church) ${ }^{2}$ are called canon ${ } \mathrm{w}^{3}$ in a technical sense, and church law in a narrower as well as usual sense.

Canon law consists of those legally regulative and protective, autonomous standards appertaining to the internal affairs of the church as a dispensary of the Gospel. The fundamental intra-church principles concerning the exercise of potestas jurisdictionis in the Catholic Church are of this nature.

In consequence of dogmatic differences the original and authoritative unity ${ }^{4}$ of the church became shattered in the Orient and later in the Occident. The ancient churchly organization, under the influence of political and other historical connections, broke up into a plurality of such associations, also called churches. A variety of church law resulted. There is a Catholic, a Greek and Lutheran church law. This diversity even became intensified in that each of these churches split up geographically (and frequently also under the influence of state politics) into different sects and national churches.

1 See supra, secs. 8, 9.

${ }^{2}$ See supra, sec. $12,(b)$.

${ }^{3}$ ( $\mathrm{Jus}$ ) canonicum is derived from $\kappa a \nu \omega \dot{\nu}$ meaning rule, plumb-line, regulation. Accordingly the accepted books of the church become the plumb-lines, or measures of belief, and are called canonical books. The designation of the small divisions (paragraphs) of church statutes, as canones, arises from this meaning.

"The term "church" appears to be referable to its foundation in Christ-

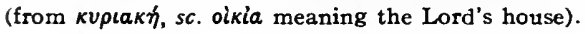


In each of such divisions concurrently with common legal standards, called jus ecclesiasticum commune, particular legal standards of political as well as churchly origin known as jus ecclesiasticum particulare prevail as opposed to jus commune of the sect or division under consideration. Each of these varieties of church law has its own history. As a rule in academic literary treatment, "church law," in general, includes the collective common law of the church and the most important peculiarities of particular church law, of the creed under consideration. ${ }^{1}$

Treatment of church law proceeds from the notion of church. It involves accordingly the historical, the practical and the dogmatic sources of this law. According to the content of the self-imposed foundations of common or particular church law of the creed under consideration, it investigates and explains the relations between State and Church; $;^{2}$ taking in turn a historical, political or purely ideal standpoint. The fundamental principles of the constitution of the church, including

\footnotetext{
2 The common and particular church law of each creed has its own literature. For reasons quickly conceivable the literature of church law of the Catholic Church is one of great volume. Of the more recent texts of Catholic and Lutheran church law are the following: Paul Hinschius, op. cit. (note 2, page 296): v. Schultc, op. cit. (note 2, page 296); Friedberg, Lehrbuch des kath. u. evang. Kirchenrechts, 5th ed., 1903; Hinschius, Das Kirchenrecht der Katholiken und Protestanten in Deutschland, Bd. I (1869-1897); Ot to Meyer, Lehrbuch des Deutschen Kirchenrechts, 3d ed., 1869; Richter-Dove-Kahl, Lehrbuch des kathol. und evangel. Kirchenrechts, 8th ed.; J. Silbernagl, Lehrb. d. kath. Kirchenrechts, etc. (Regensburg, 1880); Zoin, Lehrbuch des Kirchenrechts (Stuttgart, F. Enke, 1888); Wilhelm Kahl, Lehrsystem des Kirchenrechts und der Kirchenpolitik (first half, 1894); Paul Hinschius and Emil Seckel, Das Kirchenrecht, in Birkmeyer's Enz., p. 1417 and literature cited.

For a review of the recent literature of particular church law see v. Schulte, Lehrbuch, etc. (1886) (for Germany, pp. 36-39; Austria, p. 40; France, pp. 40, 41). See also Gareis and Zorn, Staat und Kirche in der Schweiz, Bd. I (1877); Bd. II (1878).

${ }^{2}$ See Paul Hinschius, Allgemeine Darstellung der Verhăltnisse von Staat und Kirche, in Marquardsen's Handbuch des óffentlıchen Rechts, Bd. I (general part, 1883); Gareis, and Zorn, op. cit., pp. 5, 14, 18: Hinschius, in Birkmeycr's Enz., p. 1493.
} 
church authority, its representatives and organs, and the loss and acquisition of churchly authority-the elements and organs of the church entity-are embraced in this treatment. The principles of church administration including the expression of churchly power in various church offices, and the property relations of the church follow the treatment of constitutional principles. The texts of church law as a rule also mention or treat the positive rules dealing with church life in general. They discuss the rules concerning affiliation with or withdrawal from the church, church service, churchly association, etc. 


\section{SECTION 58}

\section{COMMERCIAL LAW}

Commercial law (Handelsrecht) is the special law of commercial transactions. The economic activity which is called commerce (the sale and interchange of goods between producer and consumer) as well as a variety of pursuits which make possible or further this exchange, such as the business of transportation, insurance and banking, have been the subject-matter of special law from the time that these pursuits were exercised as regular business activities. A special law of commerce sprang up as soon as the general civil law did not suffice to protect the interests peculiar to commerce.

The necessity for special law in matters of commerce embracing those legal relations peculiar to the trading classes, as well as those legal relations arising out of commerce (or regarded as of this class of activities) was the more easily satisfied, as persons active in business pursuits in those countries where commercial law sprang up as special law, were united in permanent corporate organizations or guilds enjoying a special jurisdiction among themselves. This was a circumstance especially favorable to the origin of special legislation, as well as special custom (usages) in commercial affairs. Italy, the south of France, the north of Spain, and the cities lying in the Danube and Rhine domains are the places where commercial law in Europe first evolved as special law.

This law experienced the most important codification in France in the Code de Commerce (1807) which became the type of commercial legislation for nearly all of the 
civilized world. ${ }^{1}$ Germany arrived at similar legislation in the so-called General German Commercial Code which was the work of a commission (1857-1860), becoming effective first as state legislation, later operative as a Bund statute, and finally as an imperial statute. In connection with the establishment of the German Civil Code a revision of the commercial code became necessary, which in its new form became operative at the same time as the civil code, and is now an imperial statute.

The H.G.B. (May 10, 1897) governs commercial relations only to the extent that these relations are connected with a regular business activity.

The first book deals with: (1) trades-people; (2) the commercial register; (3) firms; (4) commercial records; (5) agents and authorities under powers; (6) clerks and apprentices.

The second book embraces the law of commercial associations, and silent partnerships, and includes: (1) public partnerships; (2) commandite partnerships; (3) share companies; (4) commandite share companies; (5) silent partnerships.

The third book deals with commercial transactions, and includes: (1) commercial acts in general and in particular; (2) sale; (3) the commission business; (4) the forwarding business; (5) warehousing; (6) the freight business; and (7) the conveyance of goods and persons by rail.

The fourth book governs commerce by sea. (Amendments, see R.G. June 2, 1902, and May 12, 1904).

In additional to this code, ${ }^{2}$ there are a number of other

'A good German translation appears under the title Die geltenden Handelsgesetze des Erdballs, by Oskar Borchardt, 3d ed. by J. Kohler with the co-operation of M. Apt and H. Dove (1904).

${ }^{2}$ On the history of this code and its revisions see Gareis. Das deutsche H.G. B., 3d ed. (Munich, 1905, C. H. Beck); also Gareis, d. H.R., sec. 3. 
statutes ${ }^{1}$ which are concerned with the standardizing of the special relations of commerce. The General German Bills of Exchange Act (1847) which antedated the commercial code, and which also is now imperial law, may be mentioned. This statute deals with bills of exchange, the most important kind of commercial paper (Wertpapiere), which as a rule are instruments drawn to order (Orderpapiere) ${ }^{2}$ and of which two chief classes have received statutory recognition and have been standardized: the draft (gezogene Wechsel), and the promissory note (eigene Wechsel).

The varieties of commercial transactions recognized by law are enumerated in the law of obligations (above sec. 23, III, particularly Nos. $1,2,5,6,7,13-24,26-31) .^{3}$

1 For example, the depository act of July 8, 1896 (Gareis R.G., 203, 204).

${ }^{2}$ Cf. supra, sec. 23 , III, No. 31 .

${ }^{3}$ For the most recent literature of German commercial law, see Cosack, Lehrbuch des Handelsrechts; Gareis, Das deutsche Handelsrecht; H. O. Lehmann, Handels-Wechsel- und Seerecht, in Birkmeyer's Enz., p. 613, and literature there mentioned. See also the decisions of the R.O.H.G. and R.Gr. in matters of commercial law published by Otto Fuchsberger, 3d ed. (Giessen, Emil Roth, 1899).

For literature of the law of bills of exchange see Kuntze and Brachmann, also Cosack, op. cit. and Gareis, op. cit.; see also O. v. Wăchter, Enzyklopädie des Wechselrechts (1880); and see also the commentaries of S. Borchardt (8th ed.), Rehbein, and Staub. 


\section{METHODOLOGY OF LEGAL SCIENCE}

\section{SECTION 59 \\ NATURE AND FUNCTION OF THE METHODOLOGY OF LEGAL SCIENCE}

Methodology of legal science deals with the kind and method of study of the science of law. It is also called juristic hodegetics ${ }^{1}$ or the learning which provides the means of scientific knowledge of the law.

The attribute of scientific knowledge is that it is systematic. It is knowledge which classifies its objects according to their similarities and differences, and according to their co-ordination and subordination, in a fixed, living and organized whole. ${ }^{2}$

There are three avenues which lead to such knowledge of a positive legal system: dogmatism, legal history and interpretation.

The dogmatic method seeks to embrace the entire extent of positive law as a system, from the beginning, and to state it as such. In this method the isolated standards of legal order are regarded at once as parts of a system. They are arranged and organized according to the laws of logic, by means of definition and classification. ${ }^{3}$

The historical method ${ }^{4}$ endeavors to exhibit legal order as a progressive unity. It shows the origin, evolution, alterations and modifications of individual legal

1 This term is derived from $\delta \delta \delta s$ (the way), $\delta \delta \eta \gamma \eta \tau \eta \dot{s}$ (the guide, leader), o $\delta \eta \gamma \eta \tau \iota k \eta$ (sc $\tau \dot{\epsilon} \chi \nu \eta$ ) (guidance, instruction).

${ }^{2}$ See supra, sec. 3.

See supra. secs. 3, 4, 12.

'See supra sec. 3. 
institutions ${ }^{1}$ in the efflux of the history of the social entity under whose authority regulative precepts of conduct develop into legal rules. ${ }^{2}$

The method of interpretation ${ }^{3}$ starts from the text of a given standard (preferably the jus scriptum) 4 and demonstrates the legal rule in itself, apart from its dogmatic connections and its historical development. It seeks to attain through the meaning of the spoken words, as they are expressed, a systematic organization without which scientific knowledge can not exist.

The existence of these three methods of study separately, or in combination, indicates that the separate divisions of positive law do not necessarily coincide with the separate divisions of legal study which are called the departments or disciplines of study.

The historical method sometimes leads to results which even ignore $^{5}$ the important distinction between public and private law, and also to variations which run counter to the systematic conclusions of legal dogma. This occurs and becomes of special importance, and as a matter of necessity, where it is historically established that the existing law of a country is a compound of foreign standards and domestic rules. In such case, each group of legal rules distinguished according to origin, requires special historical and dogmatic treatment and exposition. ${ }^{\circ}$ Legal education under the influence of political conditions, frequently finds it necessary to take account of foreign elements, or of the legal necessities of particular estates or classes of persons.

Concerning this notion see supra, sec. 5 , note 1 , page 33 .

2 See supra, secs. 7, 8, 9, 10, 11 and 12.

3 See supra, sec. 13.

4 See supra, sec. 11.

${ }^{5}$ For example in the study of German imperial and legal history:

- For example Roman private law (the pandects) and Roman legal history on one hand: and on the other, Gernan private law and German legal history. 
It therefore results that as legal science also has practical ends ${ }^{1}$ for accomplishment that there are distinctions in the legal system which require special departments of study.

The derivation of the departments of law, from the historical evolution of a positive legal system, is sketched in a masterly manner with valuable literary references by L. Goldschmidt, Enzyklopädie der Rechtswissenschaft im Grundriss (1862). In outlining the position of the law during the fourth period of Germany's legal development (that is to say, during the period of the feudal Bund up to the dissolution of the empire), this work points out and minutely examines in a series of epochs the relation between legal evolution and legal science.

The want of a legal history of the period since the 16 th century is not fully satisfied, but yet is in part most excellently supplied in the Geschichte der deutschen Rechtswissenschaft of R. v. Stintzing. This monumental example of painstaking effort, which forms the 18th volume of the history of the sciences in Germany of modern times, was published under the direction of his majesty, the king of Bavaria, by the Royal Academy of Sciences. This work, the first part of which appeared in 1880 , unfortunately was not completed by the author by reason of his sudden death. Aided by manuscripts of the late author, a second part, however, embracing German jurisprudence during the greater part of the 17th century was published in the year 1884 by Ernst Landsberg.

In the severance and development of the departments of the law the following portions of this work are of particular importance: chapter 4 (the scientific method embracing a period up to within the 17 th century); chapter 7 (origin of the synthetic method and the con-

${ }^{1}$ Cf. supra, sec. 3, I. 
test of principles up to the middle of the 16 th century); chapter 14 (criminal law-in the first part); chapter 16 (the foundation of a German legal science); chapter 17 (state law); and chapter 21 (the leaders of the evolution of state law). The third part of the Geschichte der deutschen Rechtswissenschaft by Ernst Landsberg independently, appeared in 1898. This part of the work begins with natural law and the publications on positive law the authors of which died after the year 1709. The chapters of the half volume published up to this time carry the following titles: the basis of natural and international law; the transitional period of 1680-1710; Christian Thomasius; the publicists and the Halle School; the practical jurists and the elegant jurisprudence; the summit; antiquarian investigation; the Wolffian school and others; Moser and Pütter; the war of enlightenment; the dominion of natural law; the turning point of the century. In 1898 a supplementary volume of notes and excurses (pp. 326) was published. 


\section{SECTION 60}

\section{THE DEPARTMENTS OF LEGAL SCIENCE}

Practical considerations and historical circumstances ${ }^{1}$ determine the course of legal study. The ends to be attained and practical requirements on one hand, and the reception of foreign law and the cleavages of law according to country, rank and position, associations and profession on the other hand, have led to divisions in the study of the systematic organization ${ }^{2}$ of the legal system. These divisions or disciplines may be partitioned $^{3}$ into:-

I. Principal studies;

II. Subordinate studies; and

III. Auxiliary studies.

I. The principal disciplines (according to the fundamental division of the legal system) sever into those of private law (sec. 15), noted below as A; and into those of public law (sec. 37), noted below as B.

The principal departments of study including these two groups from which follows a mixed group (C) composed of matters in common with both private and public law, require to be preceded by an "Introduction to the Science of Law" " through which juristic learning becomes easier of approach.

A. The principal disciplines of private law in Germany have developed:-

1 See sec. 59, supra. Regarding the historical evolution of academic instruction, see sec. 61 , infra.

${ }^{2}$ See supra, sec. 14 et seq.

${ }^{3}$ According to Goldschmidt, Rechtsenzyklopädie, sec. 126.

"Regarding the conception and purpose of such introduction see infra, sec. 61 . 
1. The pandects, ${ }^{1}$ the private law of Roman origin as it prevailed in Germany ${ }^{2}$ until the year 1900 , by force of customary law except where excluded by Landrecht. ${ }^{3}$ This law was known as usus modermus pandectarum," "the common civil law of Germany of Roman origin," and also as "modern Roman law." It was of subsidiary force in those states known as the domain of the common law (noted above, sec. 16b) until the establishment of the German Civil Code.

Literature of pandect law: Arndts, Baron, Bekker, Böcking, Brinz, Dernburg, Hölder, Keller, Kierulff, Puchta, Regelsberger, Savigny, Seuffert, Sintenis, Unger, Vangerow, Wächter, Windscheid (Kipp), v. Ihering (Geist des römischen Rechts), Bruns (Geschichte und Quellen des römischen Rechts, in Holtz. Enzyk., 5th ed. rev., 1900, p. 95), Erman (in J.L. B. v. K. Heft 2), Franz Leonhard (in Birkmeyer's Enz. 75-184).

2. "German private law," or the totality of legal standards obtaining in Germany, of German" origin. This discipline first arose at the end of the 17 th century, or at the beginning of the 18 th century. ${ }^{5}$ It draws its materials for its greater part from particular

1 This term is derived from the designation applied to the chief historical source of this discipline in the Justinian legislation. See supra, sec. 11, also sec. 10 .

2 Thus in Bavaria, and Hesse, so far as there was not in force an exclusive Lundrecht (as in the Palatinate, Rhenish Prussia, in Ansbach, and Bayreuth), in Württemberg, the province of Hanover, Thüringen, Mecklenberg, etc.

${ }^{3}$ Exclusive Landrecht prevailed in those countries which in 1794 belonged to the throne of Prussia, in the kingdom of Saxony, and in the countries of the French law (Rhenish Prussia, the Bavarian Rhine Palatinate, Rhenish Hesse, Elass-Lothringen, and Baden). See supra, sec 16 (b), Nos. 2-4, pp. 117-118. Regarding a similar exclusion of the Austrian B.G.B. see supra, sec. 16 (b). No. 4. page 118, supra, and sec. 60, No. 4, infra.

- Concerning the limitations on and the conditions of the operation of usus modernus pandectarum in its most proper domain see Stammler, in Archiv. f. zivilist. Praxis, Bd. 19: Die Behandlung des romischen Rechts in dem jurist. Studium nach Einführung des Deutschen Reichszivilgesetzbuchs (1855).

${ }^{3} \mathrm{Cf}$. Goldschmidt, Enz., secs. 97, 117 
private law (provincial and municipal) as well as from general customary law. Prior to the enactment of the German Civil Code the latest imperial statutes bearing on the civil law were also expounded in connection with this department of study. ${ }^{1}$

Literature: Beseler, Bluntschli (3d ed. prepared by Dahn), Gengler (Lehrb. 1854, 1862, Grundzüge 1876), Gerber (17 ed. by Cosack), Gierke, Hildebrand, von Roth, Stobbe (3d ed. Bd. I, 1893, by K. Schulz, Bd. II, 1896-1897, by H. O. Lehmann), Behrend (in von Holtzendorff's Rechtsenzyklopädie, das deutsche Privatrecht). See also the outlines of Dahn, Franklin, Gareis, Kraut (6th ed. by Frensdorff), H. O. Lehmann (in Birkmeyer's Enz. pp. 292-359 and literature there noted).

3. Commercial law, bills of exchange and maritime law. ${ }^{2}$ The material of this discipline is found in numerous imperial statutes, and in customary law; supplemented by the imperial codification of commercial law, and the law of bills of exchange. (See sec. 58).

For the literature of commercial law, see sec. 58, supra and Gareis (in J.L.B. v. K. Heft 4).

4. Private law of the various German territories and the modern private law of foreign countries. ${ }^{3}$

See the general civil code of Austria effective June 1, 1811. Literature: Zeiller, Kommentar über das allgemeine bürgerliche Gesetzbuch; von Harrasowsky, Ge-

${ }^{1}$ Cf. C. H. Dreyer, Das deutsche Reichs-Zivilrecht (Leipzig, 1876); von Mandry, Der zivilrechtliche Inhalt der Reichsgesetze (4th ed. 1898, prepared by 0 . Geip).

2 Embracing the widely prevalent chief essential elements of this law appertaining to private law; cf. Gareis, Lehrb. d. H.R., 6th ed., pp. 2, 3.

${ }^{3}$ As concerns feudal law, it may now well be said that it has ceased in Germany to be a special study of general or common law. Formerly it was such. Its material now as a rule forms a part of German legal history (see II, A, No. 3, infra) and also to a certain extent a part of German private law (I, A, 2). Concerning the nature of feudal law see supra, sec. 21, No. 3 also secs. 56 supra, and 61 infra. 
schichte der Kodifikation des österr. Zivilrechts; Pfaff $\mathfrak{u}$. Hofmann, Kommentar zum allgem. bürgerlichen Gesetzbuch; Stubenrauch, Kommentar, etc.; v. Ellinger, Handbuch d. (österr.) allg. bürg. G. B.; Unger, System $d$. österr. allgem. Priv. R.; Schiffner, Systemat. Lehrb. d. osterr. allgem. Zivilrechts; and of. Gareis, in J.L.B. v. K. Heft 4 .

(a). The Prussian Landrecht of 1794.

Literature: Dernburg, Lehrbuch des preuss. Privatrechts; Förster, Theorie und Praxis des preussischen Privatrechts (4th ed. by Eccius); Gruchot, Beiträge zur Erläuterung des preuss. Rechts (since 1877, by Rassow and Küntzel); Koch, Lehrb. des preuss. gem. Privatrechts (in v. Holtzendorff's Enz.); v. Kräwel, die altländischen Provinzen; Heydemann, die Mark Brandenburg; Schütze, Schleswig-Holstein; Bartels, Hannover; Endemann, Kurhessen; Herz, Nassau; v. Oven, Frankfurt a. $M$. Concerning the history of the drafting of the Prussian Landrecht, see Stölzel, Carl Gottl. Suarez; Koch (6th ed., Achilles) Das allg. Landrecht für die preuss. Staaten; Rehbein and Reincke, Allg. Landrecht, etc.; Schering, Allgem. Landrecht (with notes); and see also Birkmeyer's Enz. pp. 296, 297.

(b) French civil law (1807).

Literature: Zachariä, Handbuch des französischen Zivilrechts; Rivier, in Holtzendorff's Enz.; Schiffner, Lehrb. des französischen Zivilrechts; Brauer, Erläuterungen über den Code Napoléon und die Grossh. Badische Gesetzgebung.

(c) The civil code of 1863 of the kingdom of Saxony. Literature: Bernh. Schmidt, Vorlesungen über das im Königreich Sachsen geltende Privatrecht; Siebenhaar, Lehrb. des Sächsischen Privatrechts (1872), und Kommentar des Gesetzbuchs vom Jan. 2, 1863 (1864, 1865). 
(d) The Landrecht of various other territories, as the Bavarian Landrecht, the Württemberg Landrecht, and the Mecklenburg Landrecht, etc.

Literature of Bavarian Landrecht: Paul v. Roth, bayerisches Zivilrecht, 1871, (2d. ed., 1881); M. Danzer; Örtmann; H. Becher; Gottfr. Schmitt, Bayerische Justizgesetze (1903). With reference to the Landrecht of Württemberg, see Wächter, Handbuch des im Königreich Württemberg geltenden Privatrechts (1839). Concerning the law of Mecklenburg, see Böhlau, Mecklenburgsches Landrecht (1871); Roth and v. Maibom, Kurhessisches Privatrecht; Rudorff, das hannoversche Privatrecht; Bertram, Das Nassauische Privatrecht; Falck, Handbuch des Schleswig-Holsteinschen Privatrechts. With reference to late codifications of private law, see Behrend, in $v$. Holtzendorff's Enz. (5th ed., 1890, p. 387 et seq.). See also, W. Kisch, Elsass-Lothringisches Landesprivatrecht (1905).

5. The discipline of German civil law-the civil code for the German Empire, including supplementary imperial legislation and Landrecht-in its dogmatic and historical development (see sec. 61, IV, 3).

Of the literature evoked by the appearance of the German Civil Code may be mentioned:-

(a) Commentaries: (1) von Planck in collaboration with Achilles, André, Greiff, Ritgen, Unzner, Strecker and Strohal; (2) von Hölder, Schollmeyer, Fischer, Heymann, A. B. Schmidt, Habicht, Schultze; (3) von Staudinger in collaboration with Löwenfeld, Kober, Herzfelder, Mayring, Engelmann, Riezler, Wagner; also the commentary of Rehbein; (4) Oertmann, Biermann, Gareis, Frommhold, Niedner, v. Blume and Opet. Of the briefer commentaries on the B.G.B., see Neumann, Kuhlenbeck (by authority of the German bar association), and others. See also, the handbooks with ex- 
planatory notes of $O$. Fischer and W. v. Henle in collaboration with E. Ebert and H. v. Schneider (6th ed., 1904); also the legislative text with introduction and notes by K. Gareis.

(b) Systematic and dogmatic expositions of this code: (1) Endemann, Einführung in das B.G.B. (1st and $2 \mathrm{~d}$ ed. in collaboration with Gareis, now in the 8th ed.); (2) Eck, Vorträge; (3) Cosack, Lehrbuch (4th ed.); (4) Crome, System, etc.; (5) Dernburg, Das b. R. etc.; (6) Enneccerus and H. O. Lehmann (2d ed.); (7) Engelmann; (8) B. Bendix; (9) Krückmann, Inst. (3d ed); (10) Kuhlenbeck, von den Pandekten bis zum B.G.B.; (11) G. Müller and Gg. Meikel; (12) Landsberg, Das Recht des B.G.B.; (13) Matthiass, Lehrb. (3d ed., 1900); (14) R. Weyl, Vorträge über das B.G.B.; (15) J. Kohler, Lehrb. (Carl Heymann, 1904).

B. Principie studies of German public law:-

1. General state law-a theory which arrives at a systematic knowledge of the special law relating to states, which forms the subject-matter of this study, from a comparative and general viewpoint. (Cf. above, sec. 39$)$.

Literature: see sec. 39 above; here may be also mentioned, Gneist, Englische Verfassungsgeschichte (Berlin, 1882); also Archiv. für offentliches Recht by Laband and Stoerk; and the literature noted by Sarvey in Kirchenheim's Zentralblatt, Bd: III, p. 60.

2. Imperial public law.

Literature: see above sec. $39 ; f f$. secs. 42,44 , also sec. 11 , page 85 , notes 1, 2; v. Holtzendorff (5th ed.); Stoerk, in E.R.W.v. H., p. 1041; and v. Kirchenheim, in J.L.B. $v$. K. Heft. 8 .

3. Territorial public law of Prussia, Bavaria, etc.(Constitutional law).

Literature: sec. 39 , supra. 
4. Administrative law, general and territorial.

Literature: see sec. 45, supra; E. v. Meier, in E.R.W. v. H., p. 1155 ; v. Kirchenheim, in J.L.B. v. K. Heft. 8.

5. The law of civil procedure. (Cf. sec. 50).

Literature: sec. 50, supra; Binding, Handbuch, etc. L. v. Bar, in E.R.W.v. H., p. 765; Kleinfeller in J.L.B. v. K. Heft. 5 .

6. Criminal law. (Cf. sec. 51).

Literature: Geyer (5th ed.); A. Merkel in E.R.W.v. H., p. 909; Kirchenheim in J.L.B. v. K. Heft. 6 .

7. The law of criminal procedure. (Cf. sec. 52).

Literature: John in E.R.W.v. H., p. 967; Kleinfeller in J.L.B.v. K. Heft. 6.

8. The law of bankruptcy and bankruptcy procedure. (Cf. sec. 50).

C. International law and the mixed studies arising out of public and private law.

Literature: see Stoerk in J.L.B.v. K. Heft. 9.

1. International law (see secs. 54,55 ).

Literature: Stoerk in E.R.W.v. H., p. 1257; v. Liszt in Birkmeyer's Enz., p. 1345.

2. International private law (see secs. 8 at end, 13).

Literature: v. Bar in E.R.W. v. H., p. 717, and Birkmeyer's Enz. pp. 377, 738, 951.

3. Church law, general and particular of the different creeds (sec. 57).

Literature: P. Hinschius in E.R.W. v. H., p. 857; Frantz in J.L.B. v. K. Heft. 7; and sec. 57 above.

4. The private law of princely prerogative (see sec. 56 , note 1).

Literature: Hermann Rehm, modernes Fürstenrecht (1904), pp. 1-11. 
II. The subordinate studies may be divided into historical, encyclopedic [survey] and technical studies. As to the historical studies, see sec. 59. Encyclopedic studies are those which relate to the science of the law as a whole. Technical studies are those disciplines which lead to a special technic in legal science, or some other science.

A. Subordinate historical studies:-

1. History of Roman law, including also extra-legal history-the history of the Roman state, and Roman legal sources; and internal legal history (also in connection with the institutes of Roman law) - the history of Roman civil procedure, and Roman antiquitates juris.

Literature: Karlowa, Röm. R. Gesch. See also sec 60, I, A 1-literature.

2. Institutes of Roman law, or Roman private lawan essentially historico-legal introduction to legal study in general and Roman private law in particular, based on an historical foundation (I, A 1).

Literature: the institutional works of Boecking, Hōlder, Kuntze, Puchta, Salkowski, Scheurl, Sohm and others.

3. History of German law (German legal, state and imperial history,) specialized according to the age, people, or material involved: thus the particular legal history of Prussia, Bavaria, etc., or the special history of provincial law.

Literature: v Schulte, Lehrbuch der deutschen Reichsund Rechtsgeschich'e; Schröder, Lehrbuch der deutschen Rechtsgeschichte; Binding, systematisches Handbuch der deutschen Rechtswissenschaft: Brunner, deutsche Rechtsgeschichte, Bd. 1, 2, Heusler, Inst. des deutschen Rechtsquellen; Gierke, Deutsches Genossenschaftsrecht; H. Brunner, and K. Maurer in E.R.W.v. H., pp. 213, 303, 
349; K. v. Amira, Grundriss der germanischen Rechtsgeschichte in Paul's Grundriss der germanischen Philologie; H. Brunner, Grundzüge der deutschen Rechtsgeschichte (2d ed., Leipzig, 1903); and Gierke, Untersuchungen zur deutschen Staats- und Rechtsgeschichte.

B. Subordinate encyclopedic studies:-

1. Juristic encyclopedia [survey] as a propædeutic systematic outline, or review of the law (see above secs. 1, 4).

Literature: sec. 4 (end), and Erwin Grueber in Birkmeyer's Enz., pp. 5-74.

2. Comparative law (sec. 1, page 2, note 1).

3. Philosophy of the law (see sec. 3, II, including natural law).

Literature: Geyer, in Holtzendorff's Enz. (5th ed., supplemented by A. Merkel; Salis and Sommer in J.L.B. v. K. Heft 1 .

4. Juristic hermaneutics (see sec. 13).

5. Literary history of the law (sec. 59), in various divisions according to the material, period and people under consideration.

Literature: $v$. Kirchenheim's Zentralblatt, and Salis and Sommer in J.L.B. v. K. Heft 1.

6. Juristic hodegetics (sec. 59).

C. Subordinate technical studies:-

1. Medical technic: medico-legal science necessary for expert proof and the establishment of facts in civil and criminal procedure (see secs. 50, 52); medical administration (medical policing) relating to public security and welfare (see secs. $43,45,47$ ).

2. Technical juristic disciplines: the technic of diplomacy (cf. sec. 55) and diplomatics, the technic of 
non-contentious jurisdiction (prudential jurisprudence, see sec. 49), and the technic of contentious jurisdiction (Referier-und Dekretierkunst). [ Referierkunst is the art or method of stating the basis or the facts upon which a legal decision is founded. Dekretierkunst relates to the form of judicial decision. See Falck, Jur. Encyk. sec. 160. See also Anleitung Zur Ref. u. Decretierkunst (Halberstadt, 1798.)]

III. The auxiliary disciplines are all those sciences of which students in legal science who would accomplish success can not be ignorant. These studies may be divided into the following groups:-

1. The departments of humanistic learning. In the apprehension of the materials of the law considered in its scientific aspect, "classical" or humanistic learning is indispensable. In the understanding of legal sources, a knowledge of languages is especially requisite, and a familiarity with general, political and economic history is equally necessary in the understanding of the law itself.

2. State sciences, the science of finance, etc.

3. Theoretical and practical political economy. 


\section{SECTION 61}

\section{METHODS OF STUDY AND ACADEMIC EDUCATION}

I. The first method of teaching jurisprudence, of which we have any knowledge, is the exegetical method. Exegesis is the direct attainment of the formative principles of jurisprudence from the text of the sources of the law. The exegetical method accordingly consists in presenting to the student the legal sources themselves, and in instructing and directing him to develop out of the sources themselves the dogmas of the law (see sec. 3).

Under the hegemony of this method in the law schools of Italy, Germany and France of the Middle Ages, in the period of the glossators $^{1}$ and commentators, ${ }^{2}$ legal science had no other divisions than those arising out of the differences in legal sources. Civil law and canon law were distinguished, and later occasionally, feudal

1 The glossators (the School of Bologna up to about A. D., 1233) made notes glossa, on the corpus juris which after a time became fixed, and which as glossa ordinaria became the foundation of commentary. See Savigny, Geschichte des römischen Rechts im Mittelalter, Bd. V, p. 222; Windscheid, Pand., sec. 7, note 2; Stintzing, op. cit. (above, sec. 59, end) Pt. I, pp. 3, 102 , 111. Glossators: Irnerius (died bet. 1118 and 1140); the quattuor doctores (Bulga1 us, "os aureum," who died about 1166), Hugo ("mens legum," who died about 1170), Jacobus (de porta Ravennate, died 1178), and Martinus, (Gosia, "copia legum," died about 1166); Azo (Porcius Soldanus, died 1230); Azo's pupil Accursius (Accorso, died 1260) who wrote the glossa ordinaria, and his three sons, Franziscus (died 1293), Cervottus (died 1287), and Wilhelmus (died 1314); Hugolinus (died after 1233), and others.

${ }^{2}$ The glossators of the School of Bologna were followed by the School of Commentators, extending from the middle of the 13 th century into the 16 th century. They explained, or commented on, not the text of the corpus juris but the notes of the glossators (the glosses) and even on glossarum glosse, or glosses of glosses. See Windscheid, op. cit., I, p. 20, Savigny, op. cit., Bd. V, p. 299. Mos italicus was based on this commentary. Commentators: Odofredus (pupil of Accursius, died 1265), Bartolus (died 1357), and his pupil Baldus (de Ubaldis, Baldeschi, died 1400); also Jason (de Mayno, died 1519), and others. 
law. Academic instruction proceeded along the lines of these external studies, moving from one material of study to another, in no other manner and in no other succession than was suggested by the various parts or divisions of the books of these sources themselves-the corpus juris civilis, ${ }^{1}$ the corpus juris canonici, ${ }^{2}$ and the libri feudorum.

A mechanically fixed type of treatment of legal materials, developed out of the pure analytico-exegetical method introduced by the glossators, and maintained by the school of commentators. This mechanical method has been called since the 16 th century, mos italicus. $^{3}$ It produced the nucleus of an independent system in this, that the comments (commentationes, questiones) on the corpus juris were arranged in perhaps 100 to 150 favored magistraliter passages (called loci, loci ordinarii, $76 \pi 0 \mathrm{~s}$ ), and in that it was possible to derive a new connection of ideas from the legal materials by accurate selection, grouping and succession of the loci and questiones serving to a certain extent as key-words. But this magistraliter application of topics petrified into a fixed and traditional arrangement of legal materials characterized by punctilious formalism."

The conditions of a more free conception and manner of treatment of legal materials were first brought by the Renaissance-the revival of classical learning and the art of the ancients. This movement was introduced into the colleges by means of extra-collegiate lectures ${ }^{5}$

1 See supra, sec. 11.

${ }^{3}$ C. j. can.; cf., sec. 57.

3 Cf. Stintzing, op. cit., Part I, 4 th chap., particularly p. 106.

- A rule expressed in the following distich was applied to the vulgaris $e t$ usitata sive communis interpretandi ratio:

Pramitto, scindo, summo casumaue figuro:

Perlego, do causas, connoto, objicio. See Stintzing, loc. cit., p. 107

${ }^{3}$ Collegia, collegia privata in contradistinction to "lectiones," lectura of the usual exegetical course of study. See Stintzing, loc. cit., p. 132; Prantl, Geschichte der Universitat München, I, pp. 310, 410. 
in which the analytical method was superseded by a synthetical method. ${ }^{1}$ It was also furthered by means of collegiate debates fostered by the co-operation of teachers of law and their auditors which formed a literature in which the "legal method"2 was departed from, for an independent organization and classification of legal materials.

Out of the concurrence of the synthetical method with the elevation, or just beginning consideration of the historical evolution of law, arose the French historical school the leaders of which were Cujacius, ${ }^{3}$ and Donellus. ${ }^{4}$ The new method, as Donellus in particular brought it to recognition, was designated mos docendi gallicus. ${ }^{5}$ This systematic course of instruction ("methodice") in contradistinction to the exegetical method (exegesis) had a considerable vogue in Germany as early as the 17 th century ${ }^{\circ}$ and in the 19 th century the French doctrine found a widespread extension especially through the labors of Gustav Hugo.

${ }^{1}$ Cf. supra, sec. 3 (legal dogmatics). The method arrived at is appropriately indicated as: prolixa redigere in compendium, in singulis materiis, $\sigma \omega \mu a \tau o \pi 0 l \hat{\epsilon}(\nu$ et dissentientes opiniones investigata vera sententia conciliare. (Meibom, the older) Stintzing, loc. cit., p. 135.

${ }^{2} \mathrm{By}$ this is to be understood in particular that method of exposition of legal materials which followed the order of the Justinian institutes of Roman law (according to Gaius). With reference to the institutes see, sec. 11.

3 Jacobus Cujacius (Jacques Cujas, born 1522 at Toulouse, died 1590 at Bourges), was the founder of the historical school of France and one of the greatest of the world's jurists.

- Hugo Donellus (Hugue Doneau), born 1527 at Chalons, was a teacher of law at Bourges, in 1573 was a professor of law at Heidelberg, in 1588 Professor of law at Altorf, and died 1591. He was the author of one of the first systematic treatises on Roman law. As to other members of this school see Windscheid, Pand., sec. 8 , note 2 , and literature there noted.

${ }^{5}$ Of the influences supporting this method (especially that of Petrus Ramus) see Stintzing, loc. cit., p. 144.

${ }^{6}$ Stintzing, loc. cit., cap. $\mathrm{X}$ and $\mathrm{XI}$.

${ }^{7}$ Gustav Hugo, born 1764 at Lörrach, was professor of law at Göttingen, and died 1844. His "Lehrbuch der Geschichte des römischen Rechts (1790, 11 th ed., 1832) was a preliminary work chiefly from the historical standpoint. The systematic treatment of the law, mentioned above is given in his "Institutionen des heutigen römischen Rechts (1789). 
Based upon a freedom of investigation attained through emancipation from mos gallicus and the legal method, the Practical School ${ }^{1}$ unfolded after a time; especially in the Netherlands and in Germany during the $16 \mathrm{th}, 17 \mathrm{th}$ and $18 \mathrm{th}$ centuries. Toward the end of the 18th century, the School of Natural Law ${ }^{2}$ arose in Germany. This school was followed by the new Historical School founded by Gustav Hugo, to whom credit is due for the classification of the materials of the civil law now in use. The Historical School was raised to its highest position of prominence through the labors of Friedrich Carl von Savigny. ${ }^{3}$

II. This newer systematic and historically derived conception and manner of exposition of the law developed in connection with the treatment of private law. But these methods also found application in those departments of the legal complex which had attained a special place alongside of civil law. From the beginning of a legal science in Italy, France and Germany, this application was made in canon and in feudal law, and not to any lesser extent in all later branches of legal study.

The origin of the law of civil procedure as a special department of law is due to the great practical differences between the pure Roman and Byzantine juridical system on one side, and the Germanic judicial and procedural systems (domestic to Germany and France) on the other. The origin also of the departments, criminal law, and criminal procedure, leads back to an awakened

\footnotetext{
1 See Stintzing, loc. cit., cap. XII, XIII.

${ }^{2} \mathrm{Cf}$. Windscheid, Pand., sec. 8 (end) and literature: see also supra. page 18, sec. 3, II, note 6 (Gierke) and page 19, note 2 (Bekker).

Friedrich Karl von Savigny, born 1779 at Prankfurt a. M., was professor of law at Landshut and Berlin, was also Prussian minister for the revision of legislation, and died 1861. His great systematic work, System des heutigen römischen Rechts (1840-1849) unfortunately was not completed.
} 
interest long deferred among practical men, which first started in Germany in the middle of the 16 th century. ${ }^{1}$ Later, in the 17 th century, state law and international law branched out as special studies.

It is now admitted that governmental entities ruling with sovereignty and by force require to submit their community interests to legal protection, and to pursue these interests within legal limits. This conception was neither admissable nor obvious either in ancient times or in the Middle Ages. ${ }^{2}$ The prevalence of force in public relations within the state suggested the consideration and justification of these relations solely from the standpoint of politics; and jurists looked with disdain on the efforts of publicists to construct a public law. ${ }^{3}$ The advantages of juristic education to practical politicians, ${ }^{4}$ the cultivation of ancient philosophy, and the influence of the School of Natural Law, ${ }^{5}$ also resulted in placing international law, and state law as well, in an independent academic position, ${ }^{\circ}$ as early as the 17 th century.

The 16th century saw the beginning of a scientific treatment of domestic German private law (not simply in connection with, but as distinguished from Roman law) with a kind of local legal literature (StadtschreiberLiteratur) $;^{7}$ but academic treatment of German particular

${ }^{1}$ Stintzing, loc. cit. p. 603.

2 The controversial literature, however, of the 14th century as to the relation between the emperor and the pope, and the many literary broadsides of the time of the Reformation already discussed the matter of state law.

3 Therefore the discourteous reproach of the 17 th century that the pursuit of jus publicum was only a "mantellum ignorantice juris civilis," to which it was retorted by the other side with equal discourtesy, $i$ meri legisti sono puri asini. See Stintzing, loc. cit., Part I1, p. 29.

"Since the beginning of the 17 th century princes have employed jurists in diplomatic missions by preference.

${ }^{5}$ This of course suggests the name of Hugo Grotius the founder of international legal science and his position with reference to natural law and to the practical side of political science.

' Stintzing, loc. cit., I. p. 666.

${ }^{7}$ Stobbe, Geschichte der deutschen Rechtsquellen, I, p. 389, II, pp. 149, 170. 
private law, and general German law, was first attained in the 18th century. ${ }^{1}$ In 1707 George Beyer ${ }^{2}$ announced the first lecture on German law. Academic treatment of Natural Law as well as the related subject, Philosophy of Law, began with the cultivation of public law. Juristic Survey was also canvassed at the same time, at least in a literary way.

III. The academic system gradually assumed in the passing of centuries, the range which it has today. The following method, however, developed:-

(a) Preliminary historical lectures: dealing with the history of the Roman law, as a preparation for the dogmatic of Roman law (the pandects); and an examination of German state and legal history as a preparation for the systematic exposition of German public and private law;

(b) This course was followed by dogmatic lectures on the progressively evolved, freer systematic arrangement of Roman law (the institutes and pandects), attained through mos gallicus, and on German private law, canon, feudal, and public law and the law of procedure;

(c) Exegesis with the design of attaining a more definite knowledge of the sources, and the valuation of their position, partly in connection with recitations and in part through exegetical lectures, or through practical exercises; and dealing chiefly with the exegesis of the corpus juris civilis and to some extent with the new codes;

(d) Practical exercises were also employed for enlarging the knowledge of the sources, and establishing a

1 A professorship of Saxon law was established at Leipzig in 1712, of domestic (German) law at Kiel in 1712, of the law of Württemberg at Tübingen in 1720. See Stobbe, op. cit., II, p. 417 , and his Hermann Conring, der Begründer, etc. (1870).

${ }^{2}$ George Beyer, born 1665 at Leipzig, was professor of law at Wittenberg from 1706. and died 1714. Cf. Stobbe, op. cit. (Geschichle, etc.), II, p. 418. 
practical connection between theoretical learning and the actual conditions of life. Recapitulations of the subjects embraced in the dogmatic section of study were also resorted to. For review purposes there have been in use for a long time special repertories, quizbooks, etc.

IV. The course of modern juristic study in Germany is essentially governed by conditions and regulations which have been brought about by the enactment of the German Civil Code. This circumstance has been serviceable in obviating in a happy manner, difficulties which had attached, until the most recent times, to the methods of juristic study in Germany; and which gave frequent occasion for adverse criticism, and suggested betterments in juristic methods of study. ${ }^{1}$

The following principles of hodegetics have now accordingly gained asendency:-

1. Juristic study is introduced by a course which is called "Introduction to the Science of Law," a study which only in the most recent times has attained its proper position. It is the function of this discipline to present to the existing knowledge and learning of the student according to the fundamental principles of education, an introduction to juristic study, divided into three chief divisions.

$1 \mathrm{~W}$ Reuling, a barrister of the Imperial Supreme Court, comments on the unpedagogic character of the juristic instruction of former times in his article, Zur reform der juristischen Studienordnung (Leipzig, Veit and Comp., 1887); see also Gareis, Ueber die. Einführung in das Studium der Rechtswissenschaft (rectoral address of April 15, 1894) (Berlin, J. Guttentag, 1894). It gives the author a great deal of satisfaction to be able to state here that the basic ideas of his rectoral address have been carried out, and that in consequence of this, the deficiencics in juristic study which were pointed out in the first edition of this survey (1887) have been removed (particularly those pointed out on pp. 184, 185). Inasmuch as there is now universally provided an introductory course under the title, "Introduction to the Science of Law," or a course similar to it, it can no longer be said that the choice of the introductory work in juristic study is unfit; cf. p. 18.5, of the first edition. 
The first part begins necessarily with a description of those relations and conditions of life and fact which are present in the experience of the student as legal relations, and of which v. Ihering, in his Jurisprudence of Everyday Life (Jurisprudenz des täglichen Lebens) notes examples in our daily experiences. The nature of law, the necessity of the state and legislation, the meaning of customary law, the conception of interests and protection of interests, and connected therewith the notion of rights, are explained in this part.

The second part of this introductory study embraces the fundamental principles of classification of the science of law.

The third part gives a sketch of the historical origin of existing law.

In the second part the simplest classification of the law must be so far treated as may be necessary in connection with the third part to give a knowledge of each of the existing legal disciplines, departments, or courses, as parts of an organic whole. The development of this part is most clearly explained, when proceeding from the principle of egoism and when the conception of interests which living beings have and experience, is treated in connection with this principle. It is the mission of all legal order in part to limit the interests of natural persons and human societies, and in part to give them security. In that this limitation on and protection of interests, in the wider extension of this introductory course, indicates relations not referable simply to civil law, but also to state and international law, there is suggested the coincidence and mutual influence of two ideas: the legal idea and the state idea. These ideas are to be elucidated, and will be penetrated to a greater or less extent by philosophical principles of legal science, and colored by sociological views, according to the individuality of the instructor. 
In the third part, the introductory course should expose the general legal history of the country in its broad outlines.

2. Concurrently with this dogmatic or systematic introduction, an historical introduction is presented. Corresponding to the two chief sources and elements of civil law current in Germany-elements which are both traceable and both of which coincided in the German Civil Code of Aug. 18, 1896-the historical introduction consists of $(a)$ the exposition of Roman legal history and Roman private law, and (b) the exposition of German legal history and the system of German private law.

In the treatment of German legal history it is not to be overlooked that it is necessary to ascribe to it a wider significance, and accordingly a greater extension, than in the treatment of Roman legal history. The latter is of consequence only so far as it relates to Roman private law, since the Roman and Byzantine public law was neither "received" nor became of influence in the legal development of Germany. German legal history, however, should devote attention also to public law. The development of the German state with all its sovereign rights and institutions, its constitutional and administrative law, its criminal law and law of procedure, etc., should by all means, be a matter of fundamental and exhaustive treatment in its legal history, equally as important, as the exposition of the development of German private law. Therefore, the course relating to the history of German law requires that it be systematically arranged and encyclopedic, and of propædeutic value for all departments of jurisprudence. ${ }^{1}$

\footnotetext{
1 Pertinent to this matter, this is the thought which is brought out in clear definition and with complete conviction by v. Amira, Ueber Zweck und Mittel der germanischen Rechtsgeschichte (1878), and by Victor Ehrenberg, Die deutsche Rechtsgeschichte und die juristische Bildung (1894), and which is also discussed in my rectoral address (op. cit., note 1, page 323, supra), p. 18.
} 
3. If, as indicated, the dogmatic and historical foundations are laid, then an advance may be made toward an exhaustive exposition of the current civil law. The German Civil Code (concurrently with supplementary and subordinate imperial and state statutes) now becomes the central point of an extended course; taking the place of the pandects. As the course in the pandects treated the whole usus modernus pandectarum with all its controversies, dogmatico-historical developments, and questions relating to the principles of private law, so should the course in the civil code, in like manner, cover the German civil law. As a rule, lectures on the civil code should be heard by beginners in legal science in the first half of the course. When broken up in a double course or when perchance there is a third special course dealing with the law of inheritance, the first two courses should not be given in the same semester; the second course should not be given before the first; and in any event lectures on the law of inheritance should follow the two first courses.

4. In contrast with the methods of study of earlier generations, modern methods of German jurists are directed more to the practical side of jurisprudence. ${ }^{1}$ Although the history of particular legal institutions of

In this address, I advanced among other things: "the course in the history of German law is naturally the backbone, or the whole skeleton of juristic education. Through it, the proper position of every individual department is pointed out; and if this is the case, then no detailed examination is so remote, or leads so far away, as not to be useful in the complete educational structure."

German legal history also requires to show what society means and what it has to accomplish-the sociological meaning of legal history -and what the future may in an increasing measure learn from this history:

That the individual ethically is not for himself alone, but that he must serve the whole which is superior to and outlives him, but which yet provides for and protects him whether this whole be the family, the clan, the conmunity, the district, or the state; see Gareis, Ueber die Einführung in das Studium der Rechtswissenschaft. p. 13 et sey.

${ }^{1}$ Cf. Adolph Stölzel, Schulung, etc. (see supra, sec. 50, page 269, note 2). pp. 18357 
German and Roman law had been deeply penetrated with the close of the last century, yet there is generally given to the student of legal science only the accomplished result of this learned investigation; and at the most only a fleeting glance at the methods of historical inquiry is provided. On this account students are now held more to practical efforts than formerly.

The schedules of study now provided for students of legal science, prescribe a large quantity of exercises, and particularly exercises in the application of the German civil law. This work is preceded by exercises in Roman and in German private law. Practical work in civil procedure, criminal law, commercial law, the law of bills of exchange, maritime law, state, administrative and church law, is required after or in connection with exercises dealing with the code; always, of course, according to the lectures of the department under consideration. These exercises which are conducted with a library equipment and seminars organized by the juristic faculty, serve the same ends as the strict seminars in the sciences. (See the ministerial order for Prussia, of Jan. 18, 1897.)

The consideration of these observations, results in the following schedule of study of legal science suitable for modern Prussia, and in the main, also to the conditions in Bavaria:-

A. Theoretical lectures:-

I. First semester:

1. Introduction to the science of law (juristic survey); (2) History of Roman law; (3) System of Roman private law; (4) Roman civil procedure; (5) Roman legal exegeticum for beginners.

II. Second semester:-

(1) Lectures not heard in the first semester; (2) German legal history; (3) Distinctive features of German 
private law; (4) German civil law: first part (general part and the law of obligations).

III. Third and following semesters:-

(1) Lectures not heard in two preceding semesters; (2) German civil law: $2 d$ part (the law of things, and family law); (3) German civil law: $3 \mathrm{~d}$ part (the law of inheritance) ; ${ }^{1}$ (4) Commercial law, bills of exchange and maritime law (after the lectures on civil law); (5) Survey of legal evolution (Prussia or Bavaria as the case may be); (6) Criminal law; (7) Civil procedure; (8) Criminal procedure; (9) Bankruptcy law and procedure; (10) General state law; (11) Imperial constitutional law; (12) Law of the German states; (13) Administrative law of Germany and the German states; (14) Church law; (15) International law; (16) Philosophy of law.

B. Collateral exercises:-

(1) Exercises in Roman law for beginners in the first semester; (2) Similar exercises for advanced students in a later semester; (3) Excrcises in German civil law, at least once each in the first and second halves of the course; (4) Exercises in civil procedure including civil law in the second half of the course; (5) Exercises in criminal law; (6) Exercises in commercial law, bills of exchange and maritime law; (7) Exercises in state and administrative law; (8) Exercises in church law.

C. In connection with lectures under division $A$, and exercises under division $B$, a participation in the labors of the various sections of juristic seminars, and supplementary lectures covering special practical departments of law and special materials of legal science, should not be neglected.

D. In addition to juristic lectures, those relating to the various branches of state sciences, especially theo-

${ }^{1}$ German civil law as a rule should be given in the first half of the course. 
retical and practical national economy (the science of political economy), the science of finance and police should be heard. The lectures on the science of finance should follow political economy and also at least one course of lectures on state law. Lectures on economic history (or a survey of the development of political economy and its organization from the fall of the Roman Empire, with particular regard to economic conditions in Germany), and lectures on statistics (theoretical statistics, statistics of population, morals and industry) may be heard in any semester; but lectures on economic statistics should follow the lectures on political economy. ${ }^{1}$

\footnotetext{
1 This in accordance with the directions for the study of state sciences, announced in the year 1300 by the faculty of political economy of the University of Munich.
} 


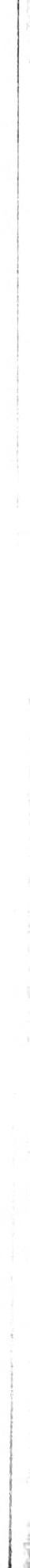




\section{APPENDIX}

\section{SYSTEMATIC CLASSIFICATION OF THE LAW}

(Systematische Gluederung des Objektiven Rechts.)

Juristic Survey . \& $1-58$

(Rechtsensyklopädie)

Introduction. $1-4$

(Einleitung)

First Part Law and its Sources $85-13$

(Vom Rechte u. $v$ seinen Quellen)

Part Second Classification \$ 14-58 (Gliederung)
Methodology of Legal Sclence. \$ \$9-61

(Methodologie der Rechtswissenschafi)

Its Nature and Functions,

(Wesen und Aufgabe derselben) \&59

Disciplines of Legal Science

(Die Disziplinen der Rechtswissenschaft) $\$ 60$

Methods of Study and Academic Instruction

(Die . Methoden und der akademische Unterricht), \&61

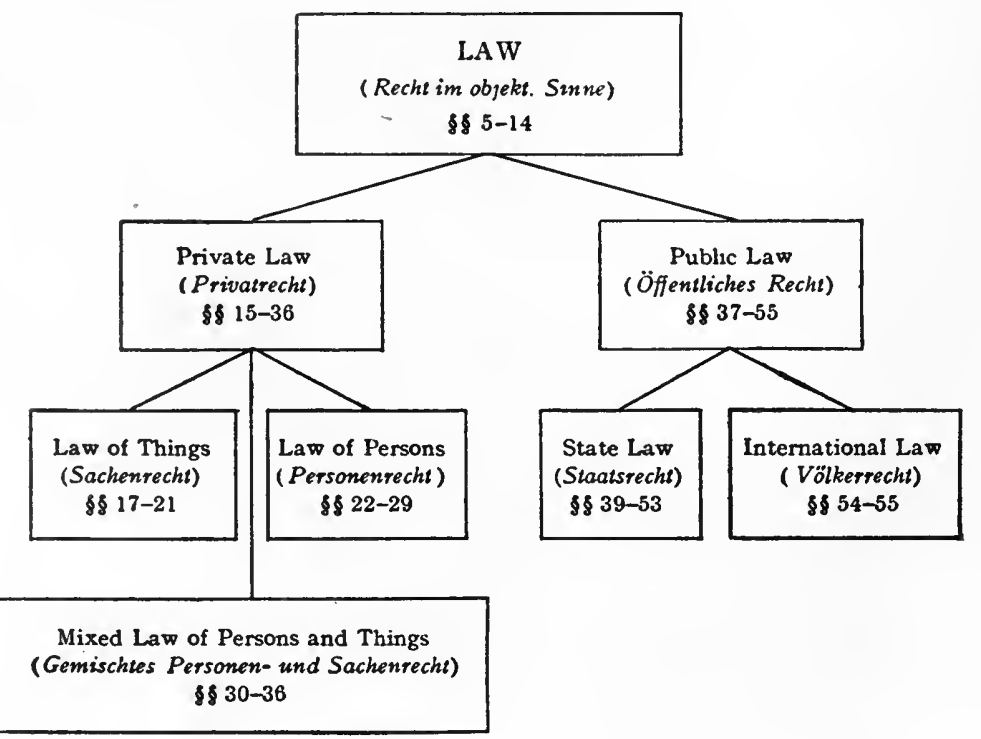




\section{Law of Things-consiresed}

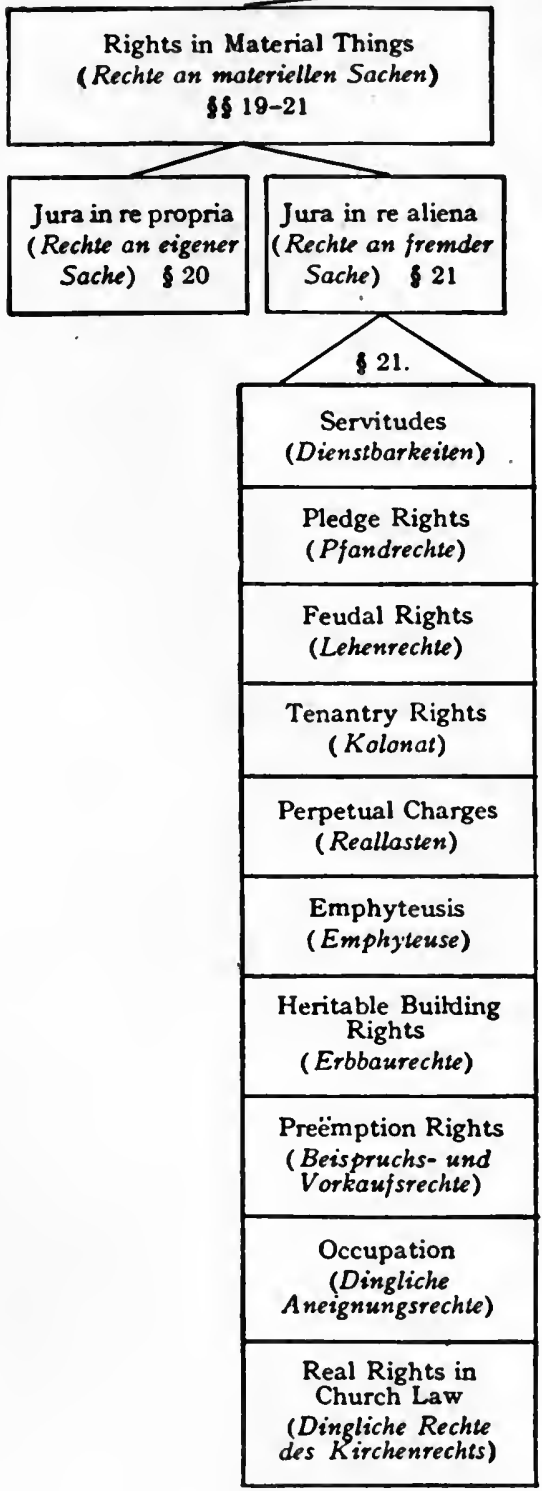

Rights in Immaterial Things (Rechte an immateriellen Sachen) 58 17-18

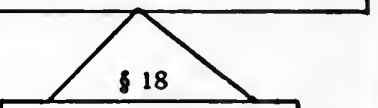

Right of Physical Integrity. etc.

(Recht auf Integrität u. Betätigung)

Name and Reputation

(Rechte auf Name. Firma, Ehre)

Trade Marks (Warenzeichenschutzrecht)

Literature and Art (Literarisch $u$. kinstl. Urheberrecht)

Artistic Models

(Geschmacksmusterschutzrecht)

Patents, and Useful Models

(Technisches Urineberrecht. Patentrecht,

Gebrauchsmusterschutzrecht) 


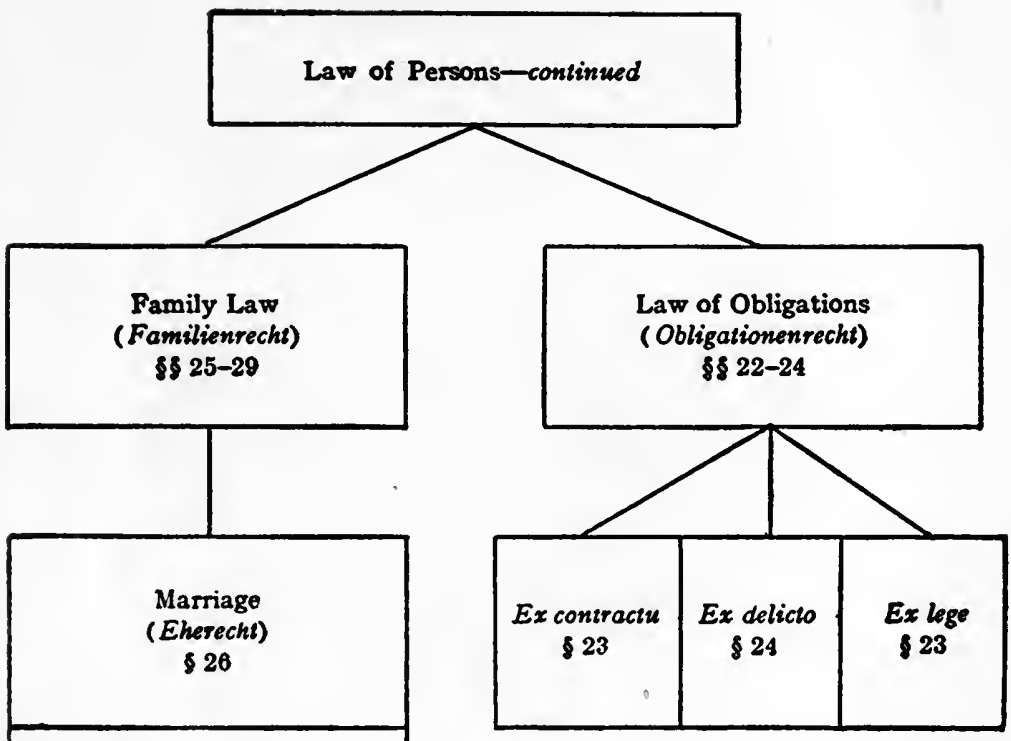

Parent and Child

(Eltern- und Kindesrecht)

827

Other Relatives by Blood and Marriage

(Verwandtschaftstecht im übr.)

$\$ 28$

Guardianship

(Vormundschaftsrecht)

$\$ 29$ 


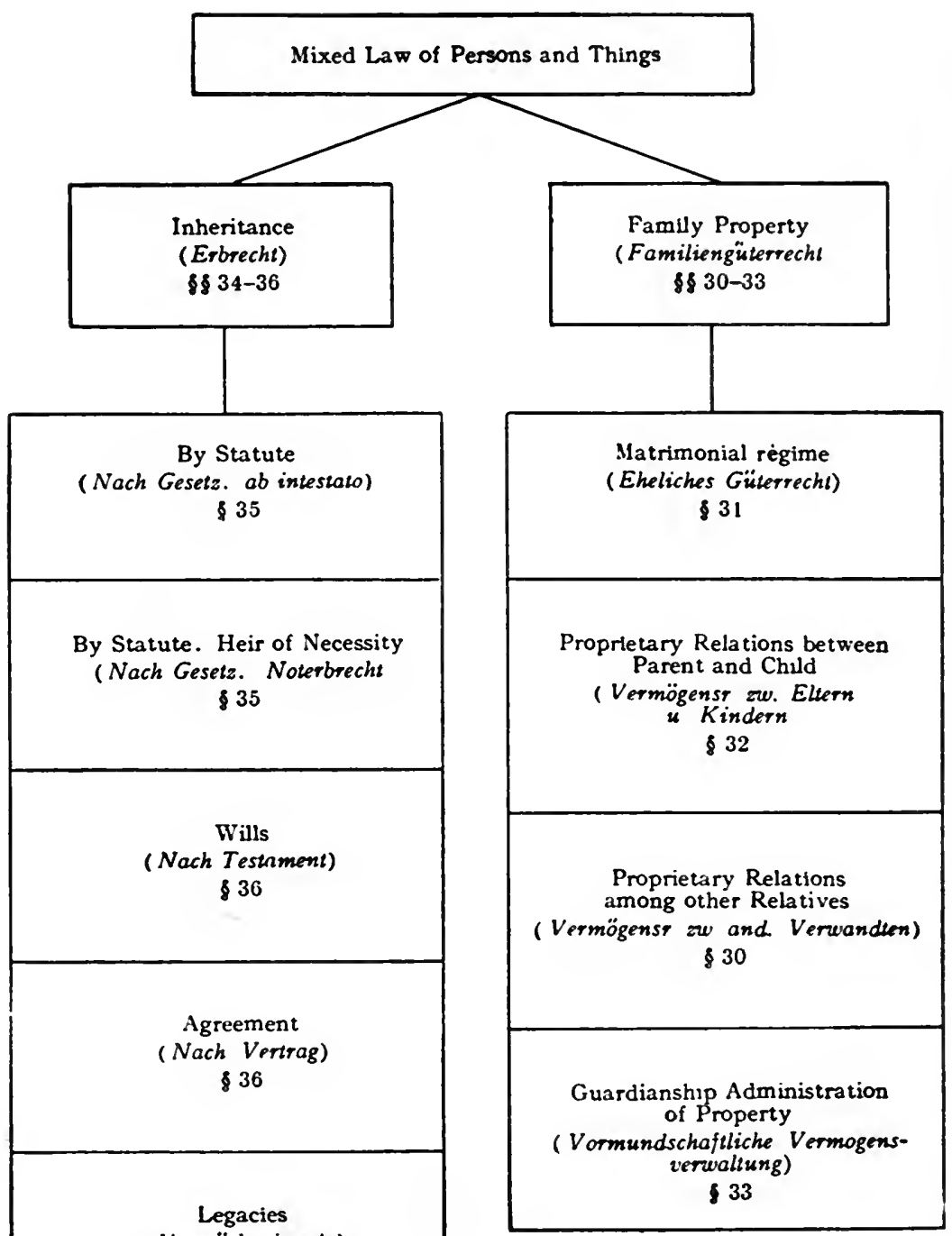


APPENDIX

335

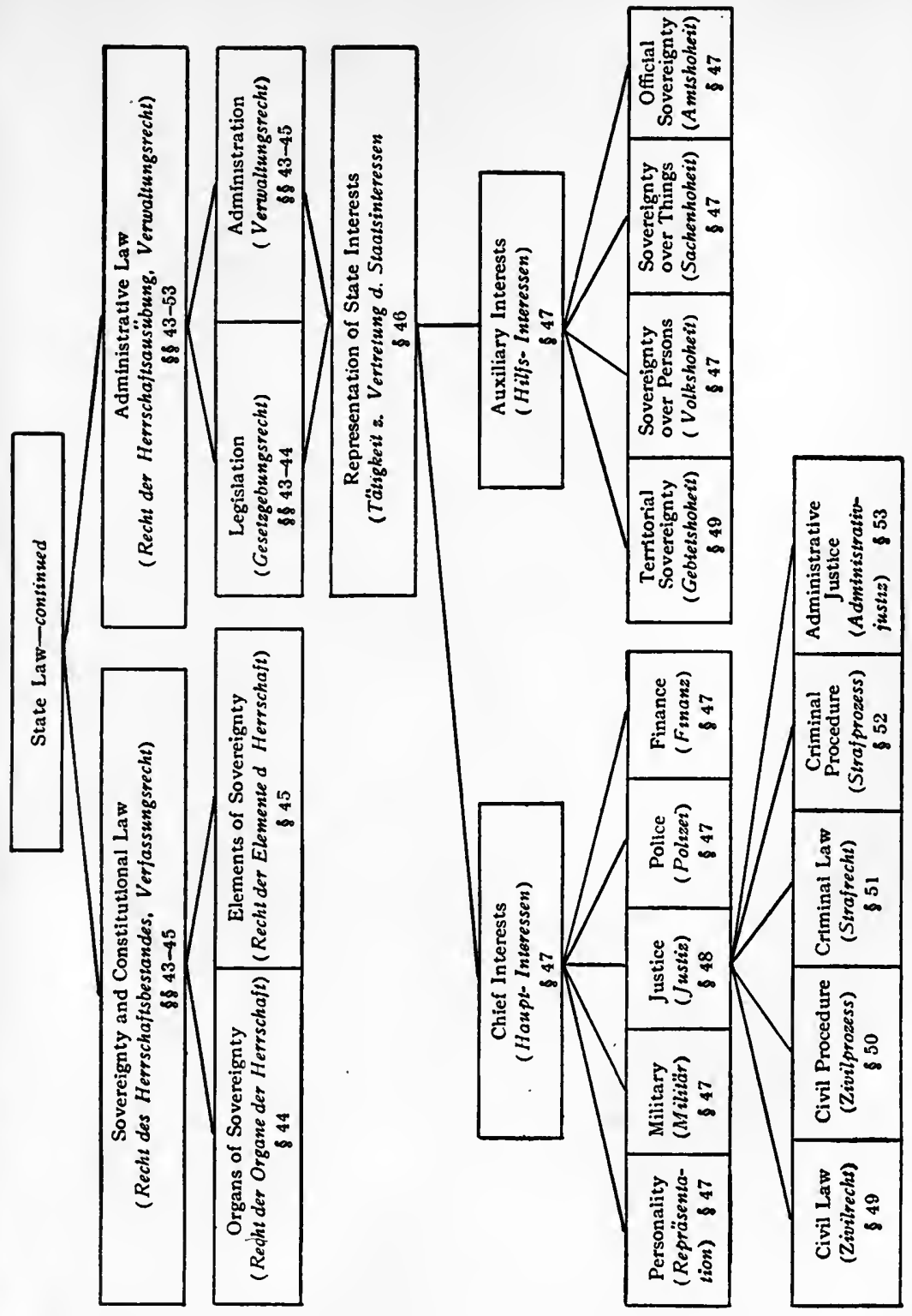




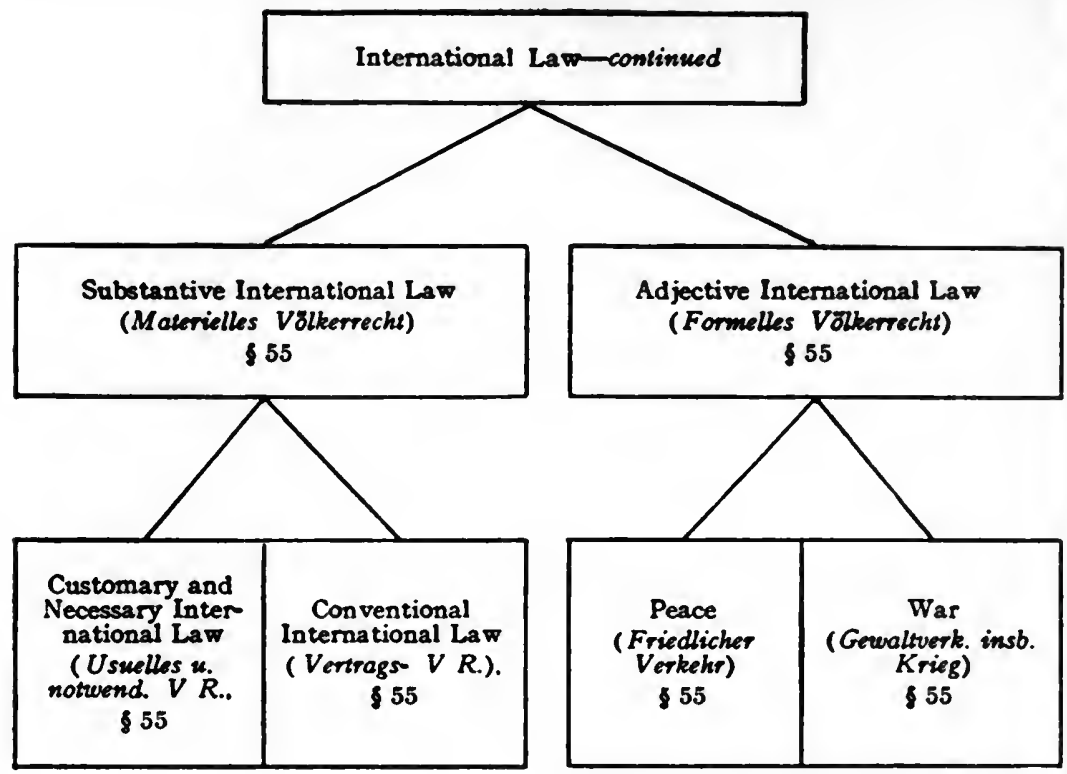

SUPPLEMENT $\$ 56-58$

Special Law

$\$ 56$

(Spezialrechte)

Church Law

57

(Kirchenrecht)

Commercial Law \$58 (Handelsrecht) 


\section{RECENT GERMAN LITERATURE}

[The following list consisting of recent literature (not otherwise noted in connection with the text) or embracing late editions of earlier works, in German, is appended in the belief that it may be found useful to readers not in touch with this class of works. Any suggestion here of completeness of selection, or of enlightenment to the juristic specialist is of course repudiated in advance. A valuable list of recent German legal and juristic literature and especially of works dealing with the special codes will be found in the annual publication Bibliotheca Juridica, which will be furnished to anyone interested by F. A. Brockhaus, Leipzig.]

Achilles-Greiff, B.G.B. (Handausgabe) 6th ed., 1909.

Archiv f. Rechts $u$. Wirtschaftsphilosophie (Kohler u. Berolzheimer). (Periodical.)

Arndts-Grueber, Jurist. Encyklopädie u. Methodologie. 11th ed., 1908.

Bekker, Grundbegriffe des Rechts, 1910.

Berolzheimer, System d. Rechts u. Wirtschaftsphilosophie (5 vols.) 1904-07.

Bozi, Weltanschauung der Jurisprudenz, 1907.

Brie, D. Volksgeist b. Hegel u. i. d. histor. Rechtsschule, 1909. Brunner, Grundzüge d. dtsch. Rechtsgeschichte, 3d ed., 1908.

Cathrein, Recht, Natu rrecht, und positives Recht (2d ed.), 1909. Cosack, Lehrb. d. bürgerl. Rechts. I., 1, 5th ed., 1909.

Czyhlarz, Lehrbuch d. Institutionen, 1909.

Danz, Rechtsprechung nach Volksauschauung u. n. d. Gesetz, 1908.

Fuchs, die Gemeinschädlickkeit der konstruktiven Jurisprudenz, 1909.

Gareis, Vom Begriff Gerechtigkeit, 1907.

Giner u. Calderon, Zur Vorschule des Rechts, 1907.

Grueber, Einführing i. d. Rechtswissenschaft, 1908. 
Hildebrand, Recht u. Sitte auf d. primitiveren wirtschaftl. Kulturstufen, 1907.

Hübner, Grundzlige d. deutschen Privatrechts, 1908.

Ihering, Scherz u. Ernst in d. Jurisprudenz, 10th ed., 1909.

Jellinek, d. Kampf d. alten mit d. neuen Recht, 1907.

Kantorowicz, Zur Lehre vom richtigen Recht, 1909.

- Der Kampf um die Rechtswissenschaft, 1906.

Kipp, Geschichte d. Quellen d. röm. Rechts, 3d ed., 1909.

Kohler, Encyklopädie der Rechtswissenschaft in system, Bearb. (Holtzendorff), 6th ed., 2 vols., 1904.

Moderne Rechtsprobleme, 1907.

Kohler-Peiser-Ungnad, Hammurabis Gesetz I, 1904; II, 1909, III, 1909.

Korn, Handbuch d. Zivilrechts, 1908.

Loening, Ueber Wurzel u. Wesen des Rechts, 1907.

Merkel, Jurist. Encyklopädie, 4th ed., 1909.

Mommsen, Juristische Schriften, 3 vols., 1905-07.

Oertmann, Gesetzeszwang and Richterfreiheit, 1909.

Petrazncki, Ueb. d. Motive d. Handelns u. a. d. Wesen d. moral u. d. Rechts, 1908.

Salkowski, Institutionen, 9th ed., 1907.

Schröder, Lehrbuch d. deutschen Rechtsgeschichte, 5th ed., 1907.

Seuffert, Zivilprozessordnung (Kommentar), 10th ed., 1908.

Sohm, Institutionen, 13th ed., 1908.

Solomon, Das Problem d. Rechtshegriffe, 1907.

Stammler, D. Lehre v. richtigen Rechte, 2 vols., 1902-07. Wirtschaft und Recht, 2d ed., 1905.

Sturm, Die psycholog. Grundlage des Rechts, 1909.

Windscheid, Lehrbuch d. Pandektenrechts, 9th ed. (von Kipp), 3 vols., 1906. 


\section{INDEX}

\section{SUBJECTS, REFERENCES AND GLOSSARY}

Page

ABKAUF DER FEHDE (purchase-settlement of the feud) . 54

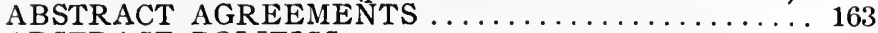

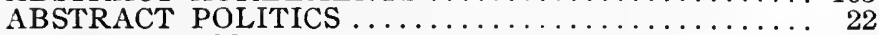

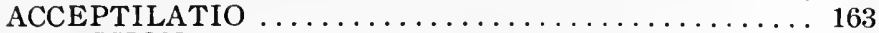

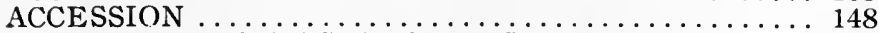

ACCREDITATION AGREEMENTS .......... 172

ACCRETION $\ldots \ldots \ldots \ldots \ldots \ldots \ldots \ldots \ldots \ldots \ldots \ldots \ldots \ldots \ldots \ldots$

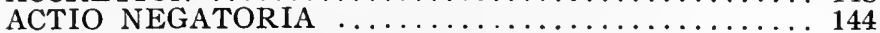

ACTIO PUBLICIANA IN REM ............... 144

ACTS, are unilateral or bilateral (see facts) . . . . . . . . 108

ADITIO . . . . . . . . . . . . . . . . . . 207

ADMINISTRATION OF JUSTICE . . . .

ADMINISTRATION in the narrow sense $\ldots \ldots \ldots \ldots \ldots 236$

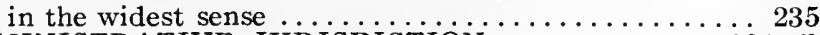

ADMINISTRATIVE JÜRISDICTION . . . . . .

does not embrace legislation $\ldots \ldots \ldots \ldots \ldots \ldots 284$

ADMINISTRATIVE LAW . .94, 97, 218, 235, ff., 241, 243, ff.

ADMINISTRATIVE POLITY (Verwaltungspolitik) . . . . 22

ADMINISTRATIV PROZESS (administrative procedure). 285

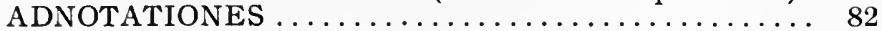

ADOPTIO IN HEREDITATEM $\ldots \ldots \ldots \ldots \ldots \ldots \ldots 204$

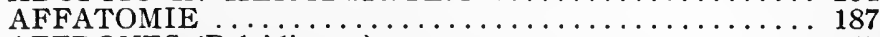

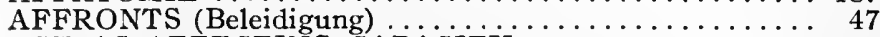

AGE AS AFFECTING CAPACITY . . . . . . . 103

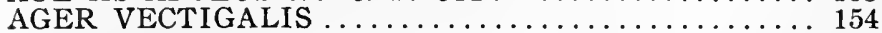

AGREEMENT (Vertrag) . . . . . .

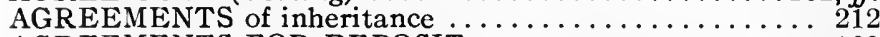

AGREEMENTS FOR DEPOSIT . . . . . . . . . . 169

AGREEMENTS FOR SERVICE, distinguished from mandate ...................... 167

AHRENS, Naturrecht oder Philosophie des Rechts. . . . . . . 19

AKTIENGESELLSCHAFT (share company) . . . . . 105, 168

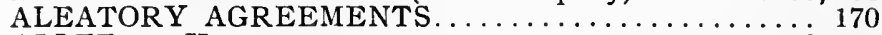

ALLFELD, Kommentar . . . . . . . . . . . . 129, 131

ALLGEMEINE GÜTERGEMEINSCHAFT (general com-

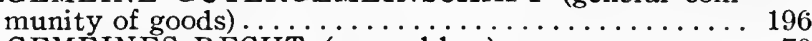

ALLGEMEINES RECHT (general law) .......... 70

ALLMENDE (undivided common, see common).

ALPINE ASSOCIATIONS. . . . . . . . . . . . . . . . 144

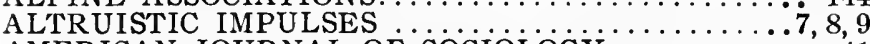

AMERICAN JOURNAL OF SOCIOLOGY …...... 41

AMERICAN LAW SCHOOLS AND JURISPRUDENCE 25 
AMIRA, Grundriss des germanischen Rechts

Grundriss der ger. Rechtsgeschichte. .

$29,78,83,157$

Zweck und Mittel der germanischen Rechtsgeschichte

AMOS, sys. view of the science of jurisprudence... 77,325 AMTSGERICHT (court of first instance) . . . . .258, 262, 270

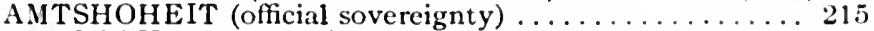

ANALOGY, governs legislative expression .......... 89

ANALYTICAL METHOD, of treatment of legal materials 319

ANARCHY . . . . . . . . . . . . . . . . 10

ANIMA LS, liability arising from ow nership of, etc . . . . 174

ANIMUS TRADENDI .................. 147

ANKLAGSPRINCIP (accusatory principle) . . . . . . 28:

ANNALEN DES DEUTSCHEN REICHES $\ldots \ldots \ldots \ldots .27$

ANNUITY CHARGES (see pledge rights).

ANSPRÜCHE (claims, q. v.) ............... 38

ANSTAND (social convention, q. v.).

AN WALTSPROZESS (procedure by attorney) . . . . . . 267

ANWALTSZWANG (necessity of acting by attorney) 268

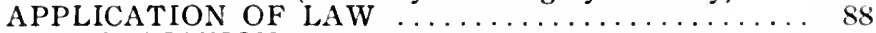

APPROPRIATION $\ldots \ldots \ldots \ldots \ldots \ldots \ldots \ldots \ldots \ldots \ldots \ldots \ldots \ldots \ldots .145,146$

AQUINAS, distinction between lex naturalis and lex

xterna ...................... 19

ARBEITSVERTRAG (a kind of commercial agreement) . 170

ARCHIV FÜR ÖFFENTLICHES RECHT . . . . . . . 240, 31.

ARCHIV FÜR RECHTS- UND IVIRTSCHAFTSPHILOSO-

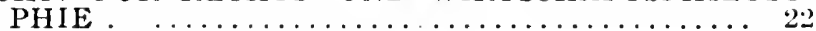

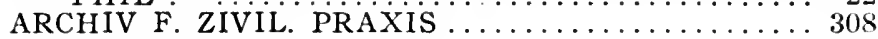

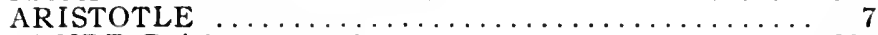

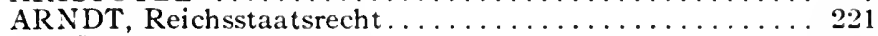

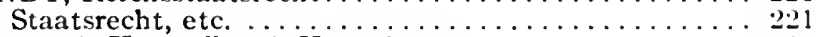

von d. Kontrollen d. Verwaltung ............ 2si

ARNDTS, Juristische Enzyklopädie . . . . . . . . . 27

ARNOLD, Ansiedelungen und Wanderungen deutscher

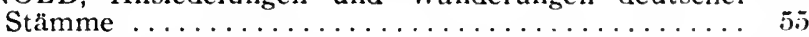

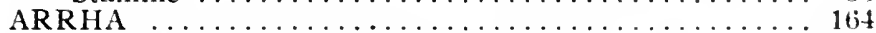

ARTIFICIAL PERSONS (see juristic persons) . . . . . . 104

ARTIFICIAL RELATIONSHIP $\ldots \ldots \ldots \ldots 187, f f ., 204,205$

ARTISTIC MODELS AND DESIGNS ............. 133, 134

ASSOCIATION OF AMERICAN LA IV SCHOOLS .....vi, viii

ATONEMENT (Sühne), a basis of criminal law ...... 67

ATRIDÆ .......................

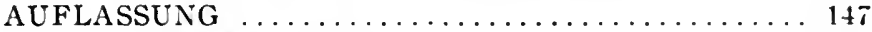

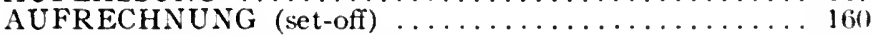

AUFTRAG (mandatum) ................ 167

AUGUSTINE, as a juristic type ............... 1:

AUSFÜHRUNGSGESETZE (supplementary statutes) . . . 25!)

AUSSTATTUNG .................... 128

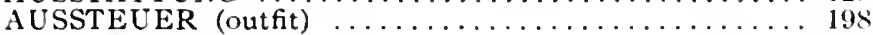

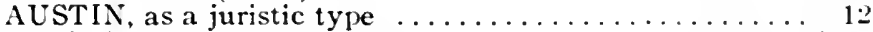
jurisprudence $\ldots \ldots \ldots \ldots \ldots \ldots \ldots \ldots \ldots \ldots \ldots \ldots \ldots \ldots \ldots \ldots, 25,20$

principles of law, morals and ethics .......... 39

AUTHEN'TIC INTERPRETATION (see interpretation). 
BAILMENTS ...................... 171

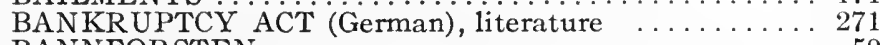

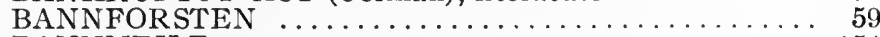

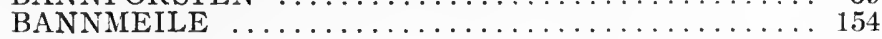

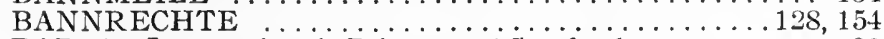

BAR, das Internationale Privat- und Strafrecht ....... 90

the in the administration of justice $\ldots \ldots \ldots \ldots \ldots 257$

BARBEY, comparison of French and English family law . 177

BASTIAN, die Rechtsverhältnisse bei verschiedenen

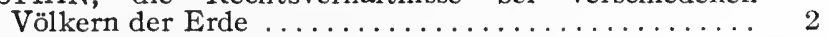

BAUER, die Strafrechtspflege, etc. . . . . . . . . . . 240

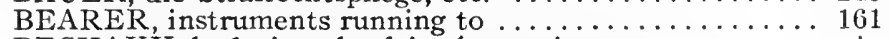

BECHAUX, le droit et les faits économiques . . . . . . . . xiv

BEGLAUBIGUNGSBEHORDEN (attesting officers) $\ldots . .262$

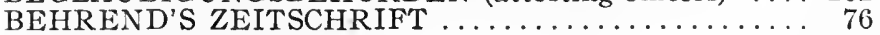

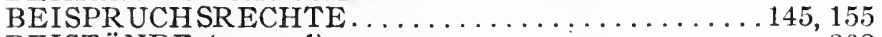

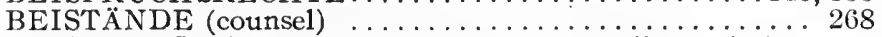

BEKKER, Streit der historischen und philosophischen

Rechtsschule ..................... 19

on the scope of philosophy of law ................. 21

regarding the notion, law $\ldots \ldots \ldots \ldots \ldots \ldots \ldots \ldots \ldots . \ldots \ldots$

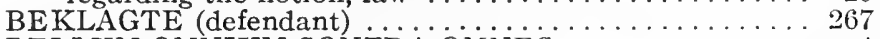

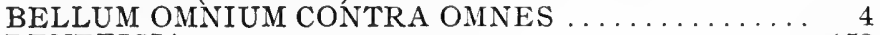

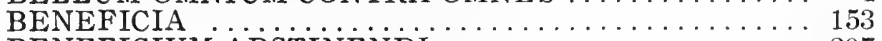

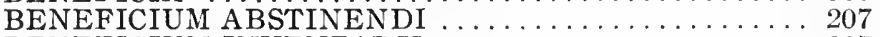

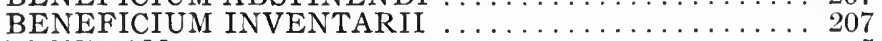

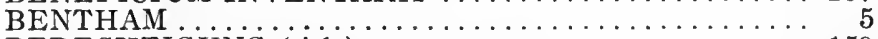

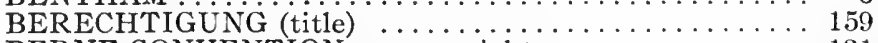

BERNE CONVENTION, on copyrights ........... 131

BERNHÖFT, on comparative law $\ldots \ldots \ldots \ldots \ldots \ldots \ldots{ }_{2}$

law compared with morals, etc. ..................... 36

the foundations of the legal system $\ldots \ldots \ldots \ldots \ldots \ldots .49$

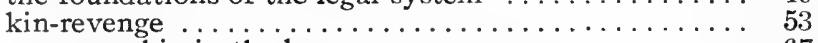

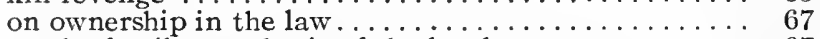

on the family as a basis of the legal system $\ldots \ldots \ldots 67$

ethical ideas in the law .................. 68

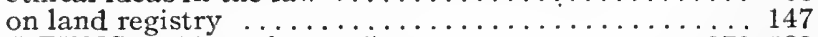

BERUFUNG (a kind of a ppeal) $\ldots \ldots \ldots \ldots \ldots \ldots \ldots 270,283$

BESCHWERDE (a kind of a ppeal) . . . . . . . . . 270,283

BESELER, Volksrecht und Juristenrecht . . . . . . . 76 deutsches Privatrecht .............

BESITZEINWEISUNG (immission, q.v.).

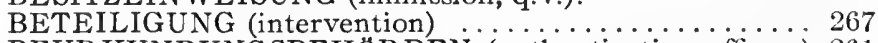

BEURKUNDUNGSBEHORDEN (authenticating officers) 261

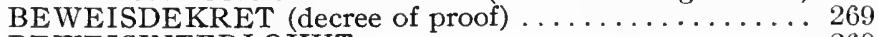

BEWEISINTERLOKUT . . . . . . . . . . . . . . . . 269

BEWEISVERFAHREN (procedure ot evidence) . . . . . . 269

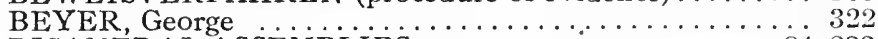

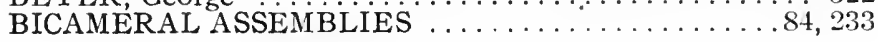


Page

BIERLING, Kritik d. jurist. Grundbegriffe ......... 10

BIERMANN, Privatrecht und Polizei in Preussen $\ldots \ldots .125$

BIGAMIA SÚCCESSIVA ................... 202

BILLIGKEIT (see equity).

BILLS OF EXCHANGE .............164, 172, 302

BINDING, die Normen und ihre Übertretung . . . . . 33, 275, 277

Handbuch des Strafrechts . . . . . . . 33, 35, 275, 276

der Rechtszwang ................... 37

deutsche Staatsgrundgesetze .............. 220

system. Handbuch d. deutschen Rechtswissenschaft 267,314

Grundriss d. deut. Strafprozessrechts ........... 282

BIRKMEYER, Enzyklopadie, 13, 27, 81, 136, 138, 145, 147, $155,221,227,238,267,271,277,282,286,287,294$, $298,302,308,309,310,313,315$

das Militårstrafrecht $\ldots \ldots \ldots \ldots \ldots \ldots \ldots \ldots \ldots \ldots \ldots 227$

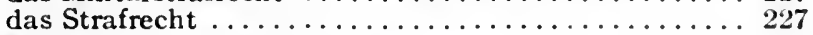

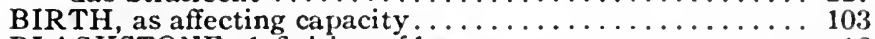

BLACKSTONE, definition of law . . . . . . . . . . 12

BLANKOPAPIERE (bills of exchange in which the payee is not designated and which are indorsed in blank) .... 172

BLÄTTER F. RECHTSANWENDUNG . . . . . . . 126, 128

BLOOD FRATERNITY $\ldots \ldots \ldots \ldots \ldots \ldots \ldots \ldots \ldots \ldots \ldots \ldots \ldots$

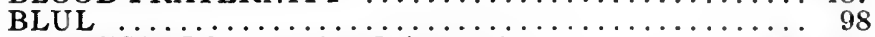

BLUNTSCHLI, deutsches Privatrecht $\ldots \ldots \ldots \ldots .9 \ldots, 129,145$

Geschichte d. allg. Staatsrechts ........... 221

das moderne Völkerrecht . . . . . . . . . . . 287

BLUTBANN (penal judicature) $\ldots \ldots \ldots \ldots \ldots \ldots 5,256,279$

BLUTRACHE (kin revenge, q. v.).

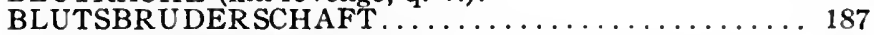

BLUTSSCHWESTERSCHAFT $\ldots \ldots \ldots \ldots \ldots \ldots \ldots \ldots \ldots \ldots \ldots \ldots \ldots$

BOISTEL, cours de philosophie du droit .......... xiv

BORCHARDT, die geltenden Handelsgesetze d. Erdballs. . 301

BORETIUS, capitularia regum francorum $\ldots \ldots \ldots \ldots \ldots 83$

BORSENGESCHÄFTE (business of stock exchanges) . . . 167

BOTTOMRY .................... 152

BRIEF-HYPOTHEK (see pledge rights).

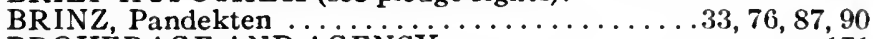

BROKERAGE AND AGENCY ............... 171

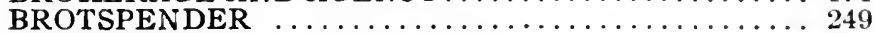

BRUNNER, deutsche Rechtsgeschichte ....56, 60, 77, 84, 314

Rechtsgeschichte der röm. u. germ. Urkunde ...... 78

Grundzüge der deutschen Rechtsgeschichte ...84, 157, 315

Geschichte u. Quellen d. D. Rechts ........... xiii

BRUNS, Ges. u. Quellen d. röm. Rechts. . . . . . . . . . . . 308

BUCH-HYPOTHEK (see pledge rights).

BÜ DNERRECHTE .................... 153

BÜHLER, Grundriss derindo-arischen Philologie . . . . . . 3, 36

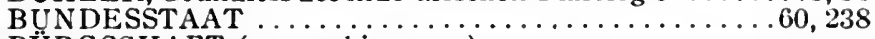

BÜRGSCHAFT (suretyship, q. v.).

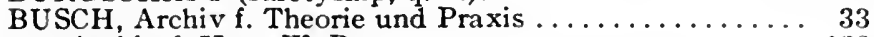

Archiv f. H. u. W. R................. 122

BUSSE, Philosophie und Erkenntnistheorie $\ldots \ldots \ldots \ldots .8$

die Weltanschauungen des grossen Philosophen ..... 8 
C $\mathrm{ESAR}$ de bell. gall $\ldots \ldots \ldots \ldots \ldots \ldots \ldots \ldots \ldots \ldots \ldots$

CALPULLI ........................... 142

CAMORRA $\ldots \ldots \ldots \ldots \ldots \ldots \ldots \ldots \ldots \ldots \ldots \ldots \ldots \ldots \ldots, 63$

CANON ...

CANONICAL IMPEDIMENTS TO MARRIAGE ...... 63

CAPACITY FOR ACTS ..............103, 193, 194, 201

CAPACITY FOR RIGHTS ................. 103

CAPITALIZATION AGREEMENTS .............. 172

CAPITULARIES $\ldots \ldots \ldots \ldots \ldots \ldots \ldots \ldots \ldots \ldots \ldots \ldots, 83$

CAPTURE MARRIAGE .................... 179,193

CARRIAGE AND INLAND NAVIGATION AGREEMENTS ......................... 170

CARRIER PIGEONS PROTECTED BY LAW........ 65

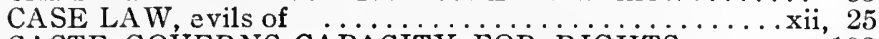
CASTE GOVERNS CAPACITY FOR RIGHTS ......... 103

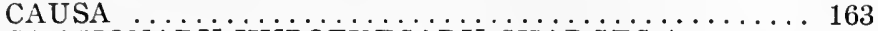

CAUTIONARY HYPOTHECARY CHARGES (see pledge rights).

CENTENEN (centen, hundreds) .............. 56

CER'TIFICATED HYPOTHEK (see pledge rights).

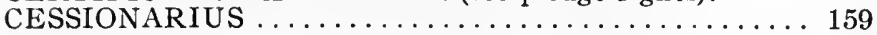

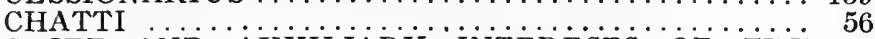

CHIEF AND AUXILIARY INTERESTS OF THE STATE IN DETAIL . . . . . . . . . . . . . . 247 CHURCH LAW ........................

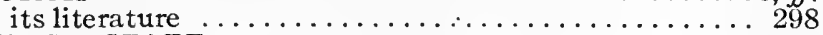

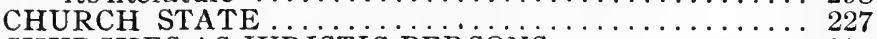

CHURCHES AS JURISTIC PERSONS …............ 296

CICERO ........................... 7 definition of law ......................... 11 as a iuristic type $\ldots \ldots \ldots \ldots \ldots \ldots \ldots \ldots \ldots \ldots \ldots \ldots \ldots, 12$

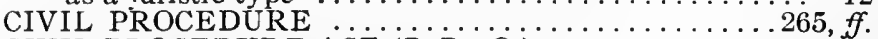

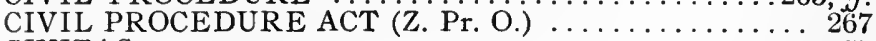

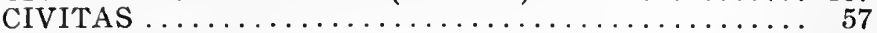

CLAIMS (Ansprüche) ........................

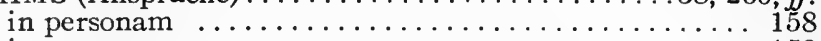

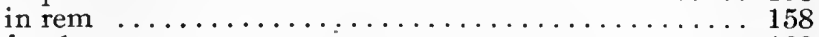
for damages ............................. 160 arising out of agreement .................. 161

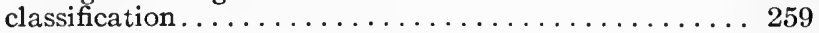

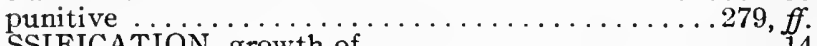

CLASSIFICATION, growth of $\ldots \ldots \ldots \ldots \ldots \ldots \ldots \ldots \ldots \ldots \ldots \ldots \ldots$ of dogmatic law....................... 17 of the corpus juris..................... 93 of the civil law ...................... 111 is governed not only by logic but by practical considerations .............................. 113 of private law in Germany ................ 114 CODE, of Manu .........3, 36, 37, 77, 147, 148, 272, 273, 277 of Hammurabi, xx, $3,4,41,153,155,158,160,179,180$, $187,195,227,240$ of Justinian became common law in Germany by reception......................... $70,114,115$ 
CODE, German bills of exchange ............. 70 German commercial .....70, $76,121,301$ (contents) Roman ......................... 8 French ........71, 116, 117, 140, 196, 308, 310 (Lit.) Saxon civil ........... 11, 116, 117, 194, 310 (Lit.)

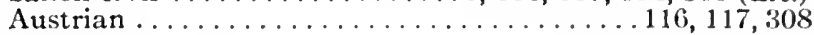
Danish .......................... 117 German civil, preparation of, xiii, 119, 267 (Lit.), 311,

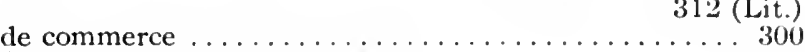

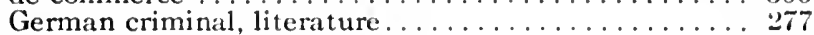

CODEX THEODOSIUS $\ldots \ldots \ldots \ldots \ldots \ldots \ldots \ldots \ldots . \ldots \ldots$

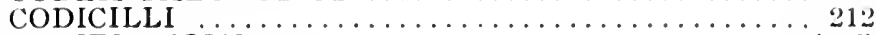

CODIFICATION

COLLECTIVE REVENGE (Kollektivrache) .......... 67

COLLEGIA CORPORA .................. 105

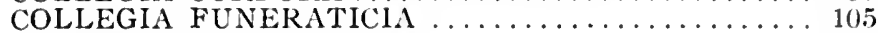

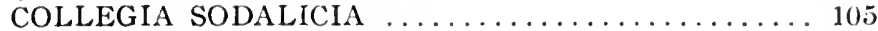

COLUMBIA LAW REVIEW . . . . . . . . . . . 89

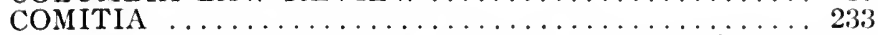

COMMENTARIES ON GERMAN BANKRUPTCY ACT. 271

COMMENTARIES ON GERMAN CIVIL CODE ...267, 311

COMMENTARIES ON GERMAN COMMERCIAI, LAW 302

COMMENTARIES ON GERMAN CRIMINAL CODE. . 277

COMMERCIAL CODE (German), synopsis .......... 301 COMMERCIAL LAW .......................

COMMERCIAL LAW, literature $\ldots \ldots \ldots \ldots \ldots \ldots \ldots \ldots \ldots$

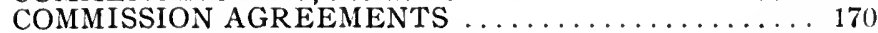

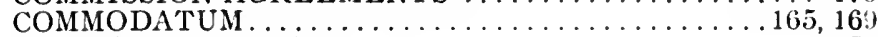

COMMON (allmende) ................... 55

COMMUNIO INCIDENS $\ldots \ldots \ldots \ldots \ldots \ldots \ldots \ldots \ldots \ldots \ldots \ldots$

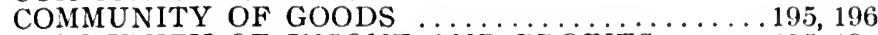

COMMUNITY OF INCOME AND PROFITS ...... 195, 190

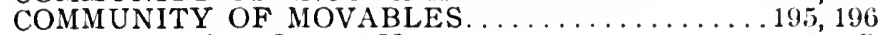

COMMUNITY PROPERTY $\ldots \ldots \ldots \ldots \ldots \ldots \ldots \ldots 194, f f$.

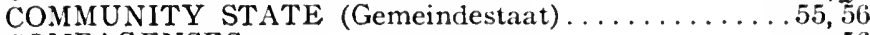

COMPAGENSES ..................... 56

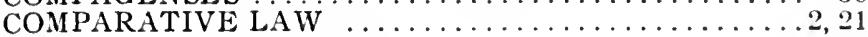

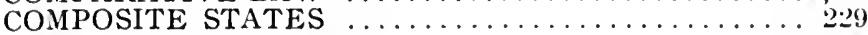

COMPOSITION SYSTEM $\ldots \ldots \ldots \ldots \ldots \ldots \ldots \ldots \ldots \ldots$

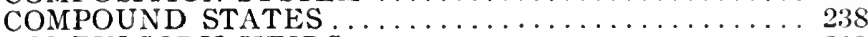

COMPULSORY HEIRS . . . . . . . . . . . . 210

COMPULSORY PORTION .................

COMPUTATION OF DEGREES OF RELATIONSHIP. 186

CONCUBINAGE ..................... 180

CONCURRENCE DEL OYY ALE . . . . . . . . . . . . . 128

CONFLICT OF LAWS. . 71, 72, 88, 89, 90, 91, 197 (marriage)

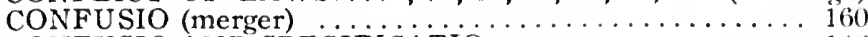

CONFUSIO AND SPECIFICATIO . . . . . . . . . . 148

CONFUSION AND SPECIFICATION $\ldots \ldots \ldots \ldots \ldots \ldots 148$

CONJUGAL COMMUNITY $\ldots \ldots \ldots \ldots \ldots \ldots \ldots 180,190, f f$.

CONSENSUAL CONTRACTS ............... 166

CONSTITUTIO CRIMINALIS CAROLINA ........ 33,227 
CONSTITUTIONAL LAW necessary to the state. . . . . . ....94, 90, 218, 220, 240, ஜf.

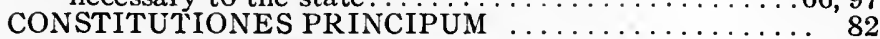

CONSULS, commercial and jurisdictional .......... 290

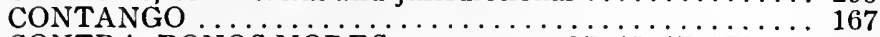

CONTRA BONOS MORES . . . . . . . $37,42,47,158,162,173$

CONTRACTUS EMPHYTEUTICARIUS . . . . . . . 154

CONTRIBUTED PROPERTY $\ldots \ldots \ldots \ldots \ldots \ldots \ldots \ldots$

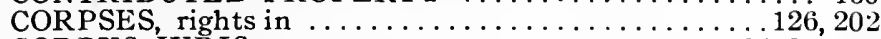

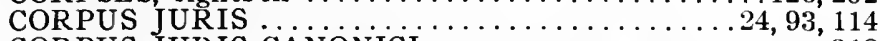

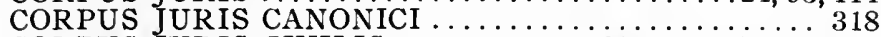

CORPUS JURIS CIVILIS . . . . . . . $82,1 \mathrm{i} 4,3 \mathrm{i} 7,3 \mathrm{i} 8,322$

COSACK, Lehrbuch d. b. R., 87, 88, $90,105,138,152,164$,

$166,167,169,170,171$

H. R. . . . . . . . . 166, 167, 168, 169, 170, 171, 172, 302

COURCELLE-SENUiL, préparation à l'étude du droit. . xiv

COURTS, classified $\ldots \ldots \ldots \ldots \ldots \ldots \ldots \ldots \ldots \ldots \ldots \ldots \ldots$

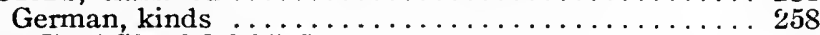

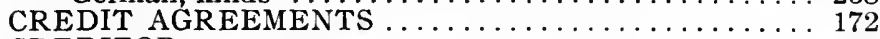

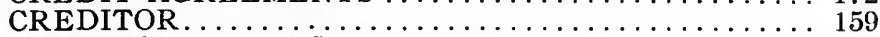

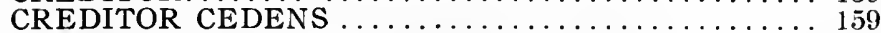

CRIMINAL CODE OF GERMANY, synopsis . . . . . 277

CRIMINAL LAW ......................

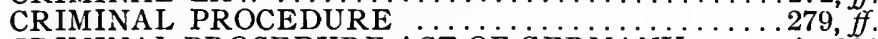

CRIMINAL PROCEDURE ACT OF GERMANY, synopsis 282

CRIMINAL PUNISHMENT, defined ...........274

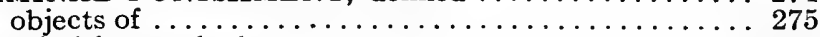

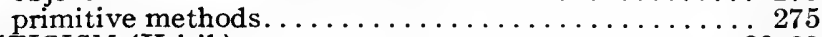

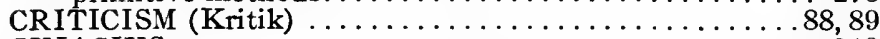

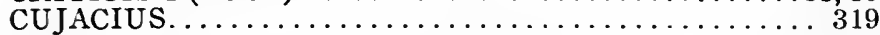

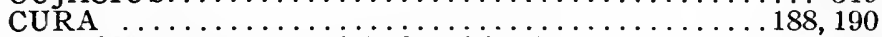

CUSTOM, creates material of positive law ........... 15

as a source of law ................... 62

does not oppose the political character of law ..... 64

of foreign countries recognized in Germany ........ 64

as a species of law-making $\ldots \ldots \ldots \ldots \ldots \ldots \ldots \ldots$

must conform to the recognized laws of reason and

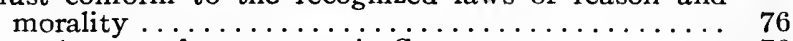

may derogate from statute in Germany ......... 76

gives way to legislation in Anglo-American system .... 77

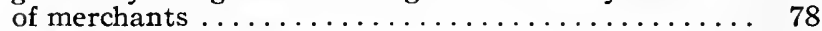

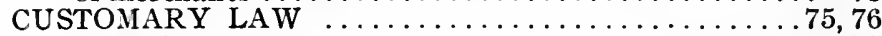

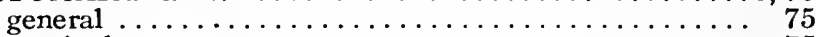

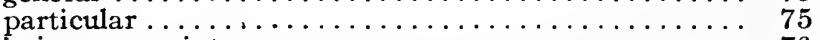

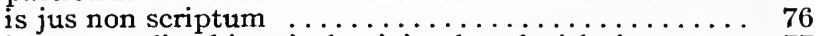

has an earlier historical origin than legislation..... 77

has a function even when legislation is highly developed 78

not formulated by the state but by the community .. 78

its authority is referable to the state......... 79

DAHN, on comparative law $\ldots \ldots \ldots \ldots \ldots \ldots \ldots \ldots \ldots \ldots$

die Vernunft im Recht $\ldots \ldots \ldots \ldots \ldots \ldots \ldots \ldots \ldots \ldots, 40,42$

uber Werden und Wesen des Rechts .........6, 43 
Page

regarding the notion, law ......................... 29

philosophy and law ................... 40

das tragische in der german. Mythologie . . . . . . 44

im neuen Reich .................... 54

Fehdegang und Rechtsgang der Germanen ........ 54

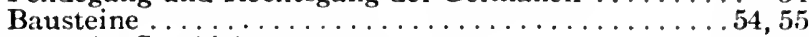

deutsche Geschichte ................... 5i

Urgeschichte der german. Völker $\ldots \ldots \ldots \ldots \ldots \ldots 55,57$

Könige der Germanen . . . . . . . . . . . . 55, 250

zur ålteren deutschen Geschichte $\ldots \ldots \ldots \ldots \ldots \ldots \ldots, 56$

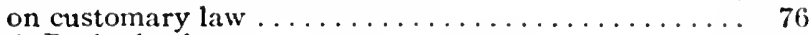

d. Rechtsbuch ..................... 2022

DAHN-BLUN'TSCHLI, deutsches Privatrecht . . . . 87, 129

DALCKE, preuss. Jagdrecht . . . . . . . . . . . 251

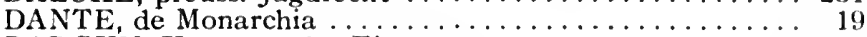

DARGUN, Ursprung des Eigentums............. 67

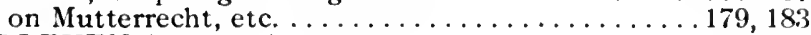

DARLEHEN (mutuum) $\ldots \ldots \ldots \ldots \ldots \ldots \ldots \ldots \ldots \ldots$

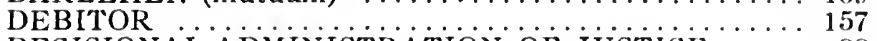

DECISIONAL ADMINISTRATION OF JUSTICE . . . . . 88

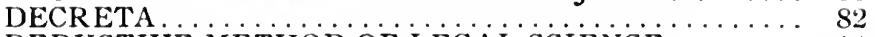

DEDUCTIVE METHOD OF LEGAL SCIENCE ....... 14

DE FACTO SUBJECTS $\ldots \ldots \ldots \ldots \ldots \ldots \ldots \ldots \ldots \ldots \ldots . \ldots \ldots$

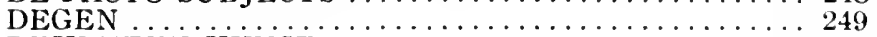

DEKRETIER KUNST $\ldots \ldots \ldots \ldots \ldots \ldots \ldots \ldots \ldots \ldots \ldots$

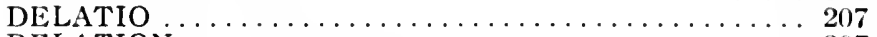

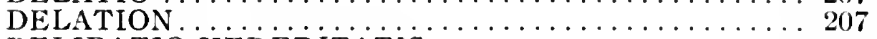

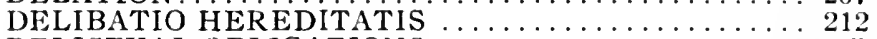

DELICTUAL OBLIGATIONS $\ldots \ldots \ldots \ldots \ldots \ldots \ldots \ldots 173, f f$.

DENARIUS DEI $\ldots \ldots \ldots \ldots \ldots \ldots \ldots \ldots \ldots \ldots \ldots \ldots \ldots \ldots \ldots \ldots \ldots$

DÉNIGREMENT (commercial slander) $\ldots \ldots \ldots \ldots \ldots \ldots 128$

DEPOSIT, as extinguishing obligations . . . . . . . . . 160

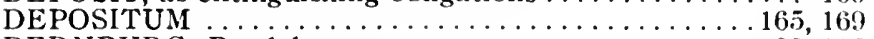

DERNBURG, Pandekten ............... 138

Lehrb. d. preuss. Privatrechts . . . . . . . . 310

DESCENT, in German law . . . . . . . . . . . . . 209

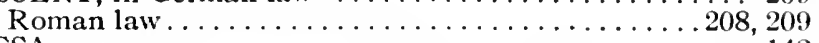

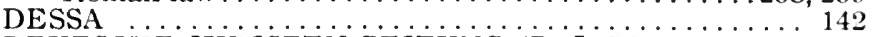

DEUTSCHE JURISTEN ZEITUNG (D. J. Z.) . . . . . 126

DEUTSCHE REVUE $\ldots \ldots \ldots \ldots \ldots \ldots \ldots \ldots \ldots, 56,7 \cdot 2$

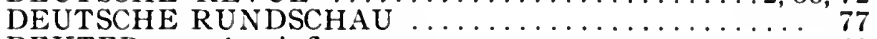

DEXTER, weather influences $\ldots \ldots \ldots \ldots \ldots \ldots \ldots \ldots \ldots 6 . \ldots \ldots$

DHARMA ........................ 3

DIENSTBAR KEITEN (servitudes, q. v.).

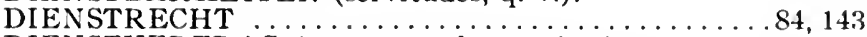

DIENSTVERTRAG (agreement for services) $\ldots \ldots \ldots \ldots, 170$

DIETZ-KÜCHLER, Verwaltungsgesetzgebung, etc. $\ldots \ldots \ldots 286$

DIFFERENTIATION OF LAW-MAKING FÚNCTION 58, 59

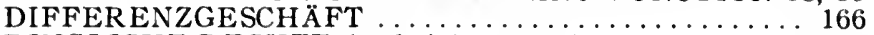

DINGLICHE RECHTE (real rights, q. v.).

DINGPFLICHT $\ldots \ldots \ldots \ldots \ldots \ldots \ldots \ldots \ldots \ldots \ldots \ldots \ldots$

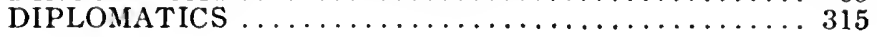


DISINHERITANCE ..................47, 210

DISPOSING CAPACITY (see capacity) ............. 103

DISPOSITIVE ACTS (see facts) .................. 108

DISTRICT COURTS (Gau courts) $\ldots \ldots \ldots \ldots \ldots \ldots \ldots, 56$

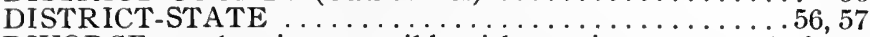

DIVORCE, conduct incompatible with marriage, a ground of 47

DOCTOR JURIS UTRIUSQUE (J. U. D.) .......... 295

DOGMATIC LEGAL SCIENCE, defined .............. 17

DOGMATIC METHOD ............................ 319

DOMESTIC SERVICE AGREEMENTS ............ 171

DOMINIUM .......................... 139

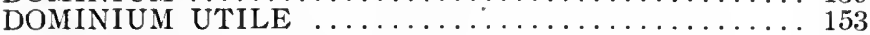

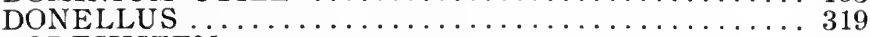

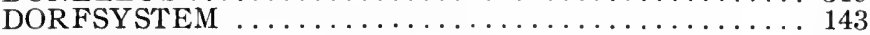

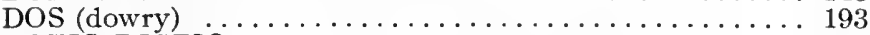

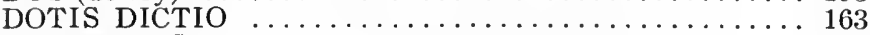

DO UT DES . . . . . . . . . . . . . . . . . 165

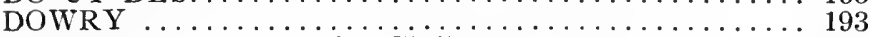

DREYER, das deutsch. R.- Zivilrecht . ........... 309

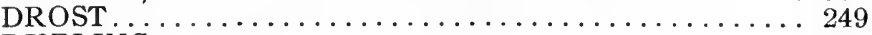

DUELING $\ldots \ldots \ldots \ldots \ldots \ldots \ldots \ldots \ldots \ldots \ldots \ldots \ldots \ldots \ldots \ldots, 63$

DUPLIK (rejoinder) $\ldots \ldots \ldots \ldots \ldots \ldots \ldots \ldots \ldots . \ldots \ldots$

DUTIES, in morals ...................... 40

DY DE, translation of Hegel's Philosophie des Rechts.... 1

EARNEST MONEY ........................ 164

EASEMENT (see servitudes).

ECCLESIA DOCENS ...................... 43

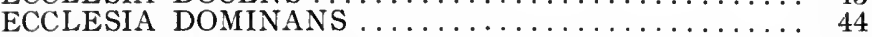

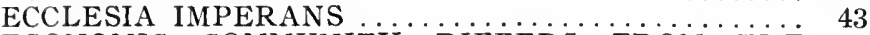

ECONOMIC COMMUNITY DIFFERS FROM THE

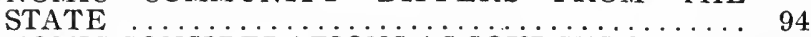
ECONOMIC CONSIDERATIONS AS SOURCES OF LA W 68

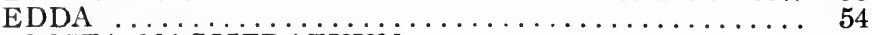

EDICTA MAGISTRATUUM $\ldots \ldots \ldots \ldots \ldots \ldots \ldots \ldots \ldots \ldots \ldots \ldots$

EDUCATION, legal, methods (see also Hodegetics)...... xi

EGOISM ............. $4,5,7,8,9,31,49,93,146,272,324$ EHELICHE GEMEINSCHAFT (conjugal community). 180, 181 EHELICHES GÜTTERRECHT (matrimonial régime) . 181, 192 EHEVERTRAG (marriage contract) …......... 181

EHRENBERG, Kommendation und Huldigung ........ 60 die deutsche Rechtsgeschichte, etc. ............ 325

EIGENBESITZER (proprietary possessor) . ............ 138

EIGENE WECHSEL (promissory notes) ........... 302

EINFÜHRUNGSGESETZE (introductory statutes) . . . . 259

EINGEBRACHTES GUT (non-privileged property) ..... 195

EINGETRAGENE GENOSSENSCHAFTEN (registered

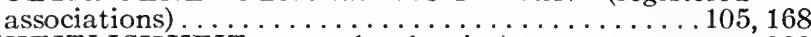

EINHEITLICHKEIT (procedural unity) . . . . . . . 268

EINREDEN (pleas) ..................38, 265, 269

EINWENDUNGEN (objections, see Einreden) ........ 269

EINZELGÜTER (individual property) ............ 55

ELEMENTAL OCCURRENCES (see facts) .......... 107 
Page

EMPHYTEUSIS $\ldots \ldots \ldots \ldots \ldots \ldots \ldots \ldots \ldots \ldots, 154$

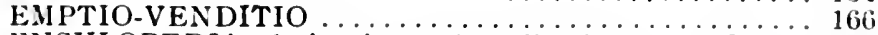

ENCY LOPEDIA, derivation and application ...... Intro., 26

ENDEMANN, Einführung in das Studium B. G. B.....126, 312

Lehrbuch d. b. R. . . . . . . . . . . . . 164, 172, 173

Handbuch d. H. R. .................... 166

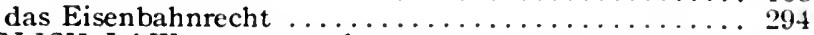

ENGLISH LAW, an ocean of cases ............ 25

ENTMUUNDIGTE VOLLJÄHRIGE (interdicted adults).. 200

ENTSCHEIDUNGEN DES REICHSGERICHTS ...... 76

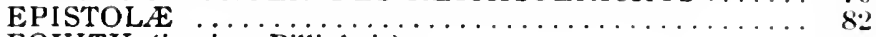

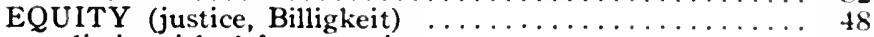

distinguished from æquitas $\ldots \ldots \ldots \ldots \ldots \ldots \ldots, 48$

is not law ........................ 48

ERBBAURECHTE (heritable building rights) $\ldots \ldots \ldots 155$

ERBPACHTEN (heritable leases) . . . . . . . . . 153, 154

ERBVERBRUึ DERUNGEN . . . . . . . . . . . . . . 12

ERBZINSRECHTE ..................... 153

ERLASS (release, q. v.).

ERRUNGENSCHAFTSGEMEINSCHAFT (community of income and profits) $\ldots \ldots \ldots \ldots \ldots \ldots \ldots \ldots \ldots \ldots$

ERSITZUNG (usucaption, q. v.).

ERWER BSGESELLSCHAFTEN (mercantile partnerships) 168

ESPRIT DE CORPS ....................... 7

ETHICAL CONCEPTION OF LAW .................. 62

ETHICAL DESTINY CONNECTS MORALS AND

RELIGION ....................... 40

ETHICAL FOUNDATION OF SOCIETY …..... 5,9

ETHICAL IDEAS IN THE LEGAL SYSTEM, 6 7,163 ,

$176,181,183,189,198,254$

ETHNOLOGICAL INFLUENCES, in public law . . . . . 100

EUDOEMONISM ..................... 36

EVENTUALMAXIME ................... 268

EVIDENCE, formal theories abandoned in Germany.... 270 EXEGETICAL METHOD OF STUDY ......... 317,322

EXNER, die Moral als Waffe im Kampf ums Dasein .......9, 40

EXOGAMY . . . . . . . . . . . . . . . . . 179

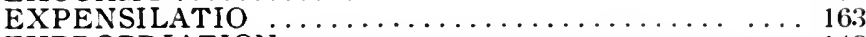

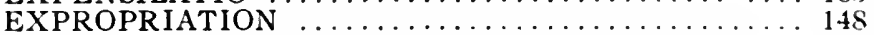

EXTENSIVE INTERPRETATION (see interpretation).

FACTORS OF A STATE ESTABLISHMENT OF LAW 66

FACTS CLASSIFIED ................... 120

FACTS GIVE RISE TO RIGHTS $102,107,108,145,148,191$

FACTS MAY AND DO ESTABLISH A BASIS OF

CLASSIFICATION $\ldots \ldots \ldots \ldots \ldots \ldots \ldots \ldots \ldots \ldots, 113$

FACULTAS AGENDI .......................... 31,34

FAHRHABE (movable things, see things).

FALCK, juristische Encyklopadie ................ 316

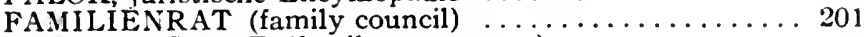

FAMILIENSTAAT (family-state, q. v.).

FAMILY COMMUNITY $\ldots \ldots \ldots \ldots \ldots \ldots \ldots \ldots, 52$ 
FAMILY, in the legislation of Justinian. . . . . . . . 53 is itself a state in absence of other dominant community 52 is the starting point of the legal system . . . . . . . 52 FAMILY LAW (pure) ................. FAMILY, one of the primary bases of the legal system ... 67

FAMILY PROPERTY ................... FAMILY, punishment in, antedates criminal law of the state 274 FAMILY RELATION, involves real and personal relations 191 FAMILY-STATE (Familienstaat) ..........53, 179

FAMILY STATUS, as affecting capacity ......... 103

FARMSTEADS (Höfe) $\ldots \ldots \ldots \ldots \ldots \ldots \ldots, 142,143$ FAUSTPFAND (see pledge rights).

FEDERAL STATES ........................ 229

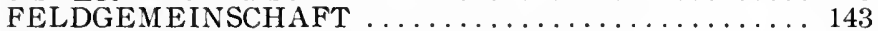

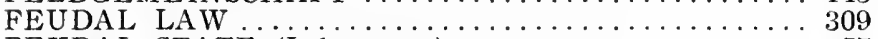

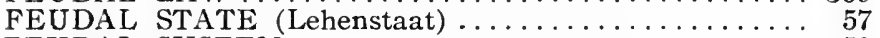

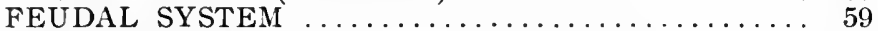

FEUDASTRUM .................. 153

FEUDUM (tenure q. v.).

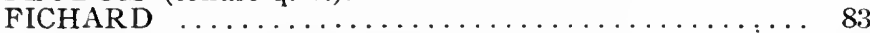

FICHTE, über die Bestimmung des Gelehrten . . . . . . . 40

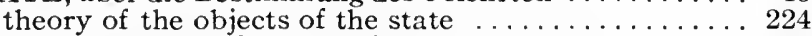

FICTITIOUS PERSONS (see juristic persons) . . . . . 104

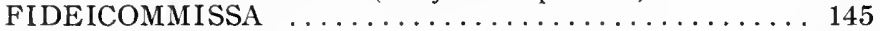

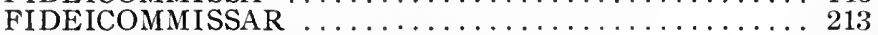

FINANZHOHEIT (sovereignty of taxation) $\ldots \ldots \ldots \ldots 215$

FINDERRECH'T (law of finding) ............ 146

FINGER, Lehrbuch d. deutsch. Strafrechts . . . . . . . 277

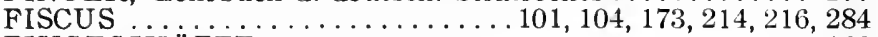

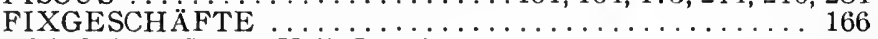

FOLK LA WS (see Volk Laws).

FORENSEN (non-resident land-holding aliens) ........ 248

FORDERUNGSRECHT (right in personam arising out of

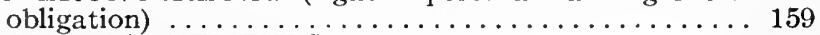

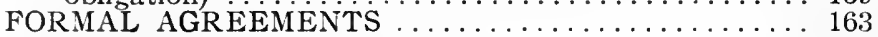

FORMATIVE ARTS, statutes protecting. . . . . . . 133

FORMULARY SYSTEM OF ROMAN LAW ....... 159

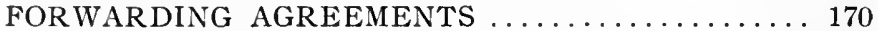

FOUNDATIONS (Stiftungen) ............. 104, 106

FOUNDATIONS OF THE LEGAL SYSTEM $\ldots \ldots \ldots 49,61$

FRANTZ, Naturlehre des Staats, etc. . . . . . . . . . 221

FREEDOM OF DOMICILE STATUTE ........... 125

FREEDOM OF WILL ...............

FREIWILLIGE GERICHTSBARKEIT (non-contentious jurisdiction, q. v.).

FRENZEL, über Entstehung der Naturalis Obligatio . . . 160

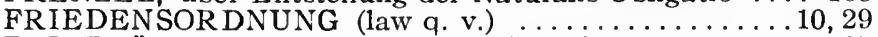

FRIEDLÄNDER, juristische Enzyklopädie $\ldots \ldots \ldots \ldots 1,27$

FRIEDRICH, die Bestrafung der Motive, etc. . . . . . . 22

FRONEN (socage service, q. v.).

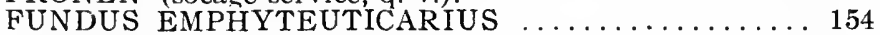

FUNGIBLE THINGS, loans of $\ldots \ldots \ldots \ldots \ldots \ldots \ldots \ldots \ldots 169$

FURTUM . . . . . . . . . . . . . . . . . . 173 
GAMING AGREEMENTS

GANERBSCHAFTEN

GANZ, on inheritance law

GAREIS, on comparative law

Lehrbuch d. H. R., $10,126,133,152,166,167,168,169$,

$170,171,172,301,302,309$

definition of law

Institutionen des Völkerrechts . . . . . 18, 86, 87, 287, 288

das allgemeine Staatsrecht, 22, 33, 60, 80, 81, 83, 100, $101,221,230,231,233,235,236,247,248,251,266$,

die Privatrechtssphăren im modernen Kulturstaat . . 33, 40 das juristische Wesen der Autorrechte ......... 33 Irrlehren uber den Kulturkampf ............... 40 early Germanic history (monograph) $\ldots \ldots \ldots \ldots \ldots . \ldots \ldots$

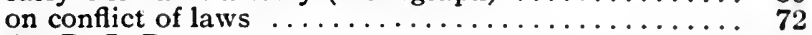

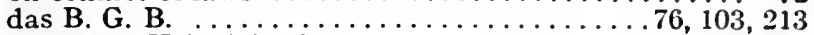
deutsches Kolonialrecht . . . . . . . . . . . 76, 294 land laws of Charlemagne $\ldots \ldots \ldots \ldots \ldots \ldots \ldots \ldots$

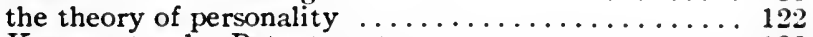
Kommentar des Patentgesetzes . . . . . . . . . . 122 Grundriss zu Vorlesungen über d. bürgerl. Recht, 122, $126,145,153,154,175,196,199,249$ das Recht am menschlichen Körper ............ 126 rights in human corpses $\ldots \ldots \ldots \ldots \ldots \ldots \ldots \ldots \ldots$ on unfair competition. ............... 128

on the law of ownership ................ 139

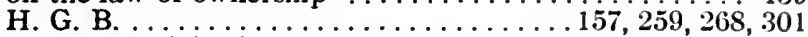

on commercial sales ................. 166

die Errungenschaftsgemeinschaft, etc. ......... 196 das deutsche Patentgesetz .............. 265 on administrative law ................. 286 die Fortschritte d. Völkerrechts ........... 287 Genfer Kovention ....................... 88 Einführung in d. Studium d. Rechtswissenschaft, 323 ,

GAREIS AND ZORN, Staat u. Kirche in der Schweiz.... 298

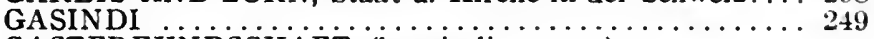
GASTFREUNDSCHAFT (hospitality, q. v.).

GAU (pagus, district) $\ldots \ldots \ldots \ldots \ldots \ldots \ldots \ldots \ldots \ldots \ldots$

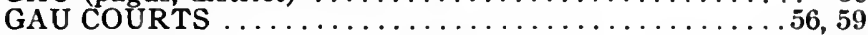

GAUGERICHTE (district or local courts) $\ldots \ldots \ldots \ldots \ldots, 59$

GAUGENOSSEN ....................... 56

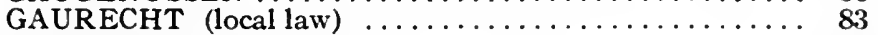

GAU-STATE (district-state) $\ldots \ldots \ldots \ldots \ldots \ldots \ldots \ldots \ldots$

GEBOTENES DING .................. 60

GEGENVORMUND (supervising guardian) $\ldots \ldots \ldots \ldots \ldots 201$

GEHOFERSCHAFTEN (farmstead communities, see farmstead).

GELEGENHEITSGESELLSCHAFTEN (adventure part-

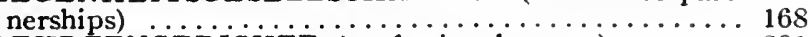

GELEHRTENGERICHTE (professional courts) ....... 281

GEMEINDEN (communities) ............... 56 
GERICHTSWESEN (judicial affairs)

GERMAN CIVIL CODE, based in form on Roman law

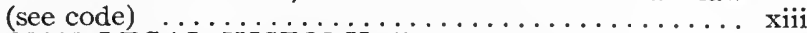

GERMAN LEGAL HisTORY, literature ................ 314

GESAMTNACHEOLGE (universal succession) ......... 206

GESCHLECHTSVORMUNDSCHAFT (statutory tutelage) ............................ 193

GESELLSCHAFTSRECHT (social law, q. v.).

GESELLSCHAFTSVERTRAG (partnership agreement) . . 168

GESETZ (law in narrow, and widest sense) ......... 84

GESETZ DER IMMANENZ ................... 10

GESETZGEBUNGSPOLITIK (legislative polity) . . . . 22, 97

GESUND ......................... 143

GEWERBEGERICHTE (trade courts) . . . . . . 259

GEWERE ........................... 138

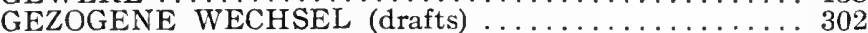

GIERKE, Naturrecht und deutsches Recht ......... 18

Jugend und Altern des Rechts . . . . . . . . . . 77

deutsches Privatrecht $\ldots \ldots \ldots \ldots \ldots \ldots 7 \overline{7}, 9 \ldots \ldots$

sociale Aufgabe des Privatrechts . . . . . . . . . . 102

on the theory of personality ............. 122

der Humor im deutschen Recht .............. 147

Untersuchungen zur deutschen R. Geschichte .... . 179, 315

deut. Genossenschaftsrecht . . . . . . . . . . . 314

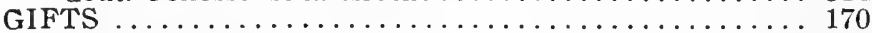

GIROVER KEHR (commercial paper transactions) . . . . 172

GLOSSA ORDINARIA .................. 317

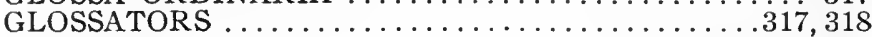

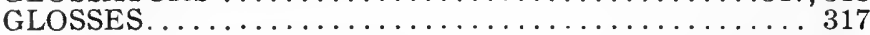

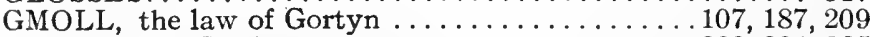

GNEIST, der Rechtsstaat, etc. ..........223, 224, 285

Englische Verfassungsgeschichte ........... 312

GOLDEN BULL ............................ 83

GOLDSCHMIDT, Universalgeschichte des Handelsrechts . .5, 10 Handbuch d. H. R. . . . . . . . . . . . . 10 defines science of law . . . . . . . . . . . . 14, 15 Enzyklopädie der Rechtswissenschaft . . . 27, 305, 307, 308

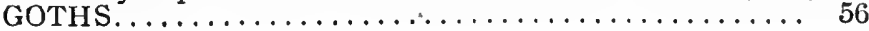


GOTTESURTEIL (the ordeal) ............... 45

GRATIAN, definition of law $\ldots \ldots \ldots \ldots \ldots \ldots \ldots \ldots \ldots \ldots$

GREEN BAG .................. xi,

GREEN, principles of political obligation $\ldots \ldots \ldots \ldots \ldots$ iv

GRIMM, deutsches Wörterbuch ............... 29

GROSS MISCHIEFS (grober Unfug) .............. 47

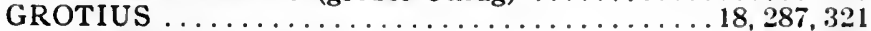

De jure belli ac pacis .................... 61

GRUCHOTS BEITRÄGEN $\ldots \ldots \ldots \ldots \ldots \ldots \ldots \ldots \ldots \ldots 126$

GRUNDBUCH (land registry) .................. 147

GRUNDDIENSTBARKEITEN (prædial servitudes, see servitudes).

GRUNDSCHULD (land charge, see pledge rights).

GRÜNHUTS ZEITSCHRIFT $\ldots \ldots \ldots \ldots \ldots \ldots \ldots 2,4,33$

GUARDIANSHIP $\ldots \ldots \ldots \ldots \ldots \ldots$ i87, 188, 190, 191, 200, 201

GUMMERE, germanic origins ............ 56

GUNDERMANN, Englisches Privat recht $\ldots \ldots \ldots \ldots \ldots 140$

GÜTERRECHTE (matrimonial property rights) $\ldots \ldots \ldots$ T0

GÜTERTRENNUNG (separation of goods) .......... 194

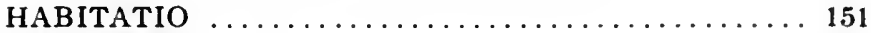

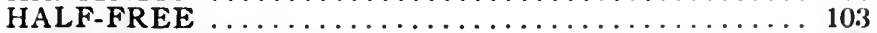

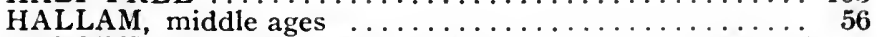

HAMMURABI, code, $x x, 3,4,41,153,155,158,160,179$,

HANDBUCH D. VÖLKERRECHTS ............ 36

HANDELSGESELLSCHAFTEN (commercial partnerships) 168

HANDELSRECHT (commercial law) . . . . . . . . 300

HÄNEL, Staatsrecht d. deut. Reiches ............ 238

HANSSEN, Agrarhistorische Abhandlungen........ 56

HARPER, code of Hammurabi ..............4

HARRASÓWSKY, Ges. d. Kod. d. Österr. Zivilrechts . . . . 309

HARTMAN, Zeitschrift f. d. öf. Recht ........33, 40, 139, 224

HASTIE, outlines of jurisprudence ..... vii, xv, xvii, 1, 19, 25

Kant's philosophy of law . . . . . . . . . . .

Lioy's philosophy of law . . . . . . . . . . . 19

HAUBERGGENOSSENSCHAFTEN (woodland communi-

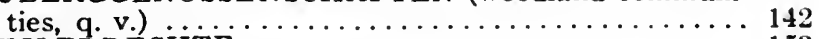

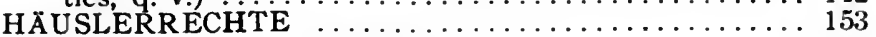

HECKER, adoption im geltenden Recht ........... 187

HEERPFLICHT (duty of military service) ......... 60

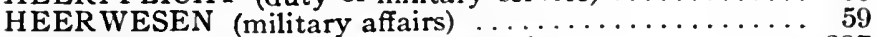

HEFFTER, das Europåische Völkerrecht $\ldots \ldots \ldots \ldots \ldots \ldots 287$

HEGEL, his conception of the universe $\ldots \ldots \ldots \ldots \ldots$ vii moral and civil duties $\ldots \ldots \ldots \ldots \ldots \ldots \ldots \ldots \ldots \ldots \ldots$

Philosophie des Rechts. . . . . . . . . . . . . 1

theory of the object of the state $\ldots \ldots \ldots \ldots \ldots \ldots \ldots 24$

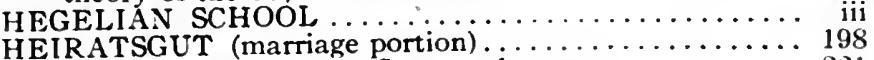

HELD. Grundzotge d. allg. Staatsrechts, etc. . . . . .

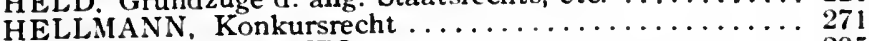

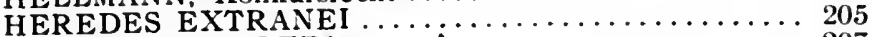

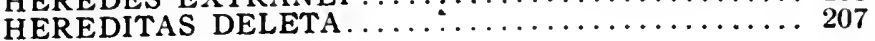


HERITABLE BUILDING RIGHTS ........................ Page

HERITABLE LEASES $\ldots \ldots \ldots \ldots \ldots \ldots \ldots \ldots \ldots \ldots \ldots \ldots$

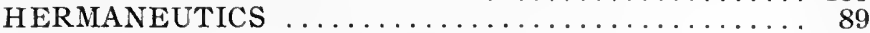

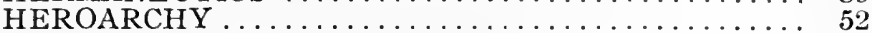

HERODITUS, on temple prostitution $\ldots \ldots \ldots \ldots \ldots \ldots 41$

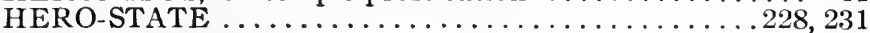

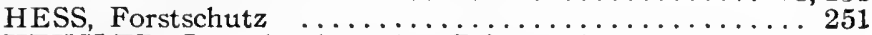

HEUSLER, Inst. des deutschen Privatrechts, 56, 138, 142,

$143,144,179,183,186,187,188,196,208,211$

Inst. des deutschen Rechtsquellen ........... 314

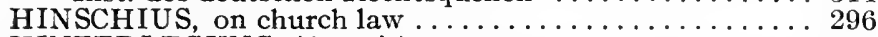

HINTERLEGUNG (deposit) . . . . . . . . . . . . . . . 160

HISTORICAL EVOLUTION OF GERMAN CIVIL LAW 114

HISTORICAL LEGAL SCIENCE DOES NOT CONFLICT

WITH DOGMATIC LAW ............... 17

HISTORICAL METHOD OF STUUX $\ldots \ldots \ldots \ldots \ldots \ldots \ldots$

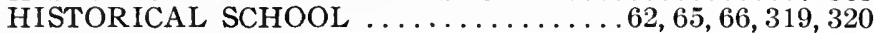

HISTORY OF JURAL IDEAS $\ldots \ldots \ldots \ldots \ldots \ldots \ldots \ldots, 23$

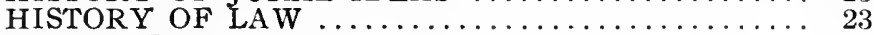

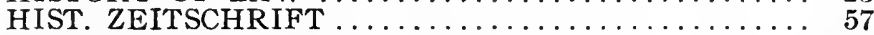

HOBBES, contract theory of the state ............. 228

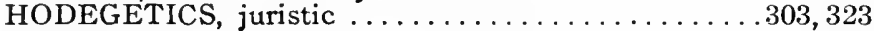

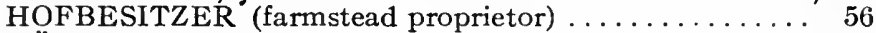

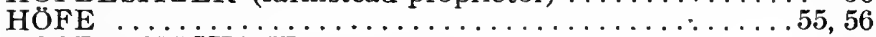

HOFFNUNGSKAUF . . . . . . . . . . . . 167

HOFMEIS'TER, die Gerichtsszene, etc. . . . . . . . 160

HOFSYSTEM (see farmstead).

HOLLDER, Pandekten .................... 90

HOLLAND, the elements of jurisprudence $\ldots \ldots \ldots \ldots 1,12,23,26$

HOLTZENDORFF, Enzyklopädie, $18,19,27,52,66,77$, $179,187,221,287,293,296,308,309,310,311,312,313$,

Handbuch d. deutschen Strafrechts. . . . . . . . . . 227

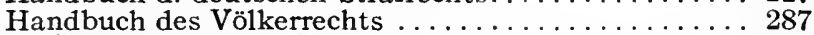

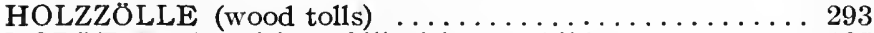

HORLE, legal position of illegitimate children ....... 185

HOSPITALITY (Gastfreundschaft) ...........53,68

HUE DE GRAIS, Handbuch der Verfassung, etc., in

Preussen ....................... 286

HUGO, Inst. d. heut. röm. Rechts . . . . . . . . . . . 319

Lehrb. d. Geschichte d. röm. Rechts . . . . . . . . . 319

HUMANISTIC LEARNING INDISPENSABLE IN

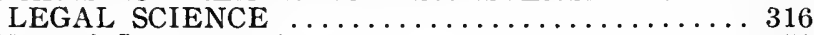

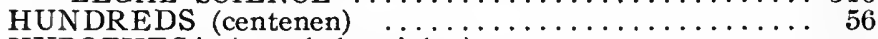

HYPOTHECA (see pledge rights).

HYPOTHECARY CHARGE................. 152

HYPOTHEK (see pledge rights).

IHERING ...................... 7 der Zweck im Recht $\ldots \ldots \ldots \ldots \ldots \ldots \ldots \ldots, 33,102$

Geist d. röm. Rechts . . . . . . . . . . . . . 308

Jurisprudenz d. täglichen Lebens ............. 324

ILLINOIS LAW REVIEW ............... Xiii 
IMUNENT LEGAL PRINCIPLES ${ }^{\circ}$ Pagc

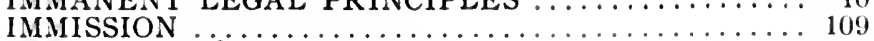

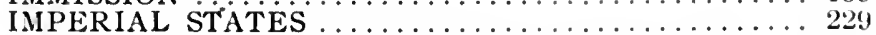

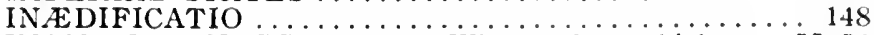

INAMA-STERNEGG, deutsche Wirtschaftsgeschichte $\ldots 55,56$

Verwaltungslehre ....................244

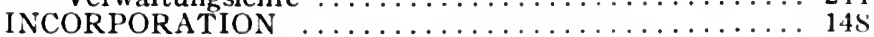

INDIVIDUALISM AND SOCIAL WELFARE ....... 25

INDUCTIVE METHOD OF LEGAL SCIENCE $\ldots \ldots .14$

INFORMAL AGREEMENTS .............. 165

INHABERPAPIERE (instruments payable to bearer) 161, 172

INHERITANCE, law of $\ldots \ldots \ldots \ldots \ldots \ldots \ldots, 202, f f$.

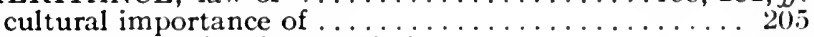

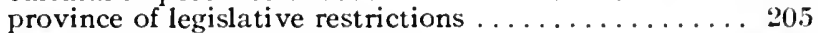

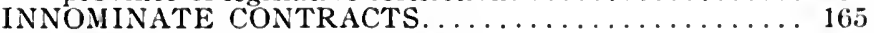

INQUISITION, general and special .............. 282

INSURANCE AGREEMENTS . . . . . . . . . 171, 172

INTABULIERUNGSGERICHTE (intabulation courts) . . 261

INTENTIO . . . . . . . . . . . . . . . . . 159

INTERESSENTRÄGER (owner of an interest, see legal subject) .................... . . . 102

INTERESTS ARE THE BASIS OF RIGHTS, $10,11,20$,

INTERNATIONAL LAW

based on common interests of states $\ldots \ldots \ldots \ldots \ldots$ is a division of public law . . . . . . . . . . . . systematic survey of its content . . . . . . . .

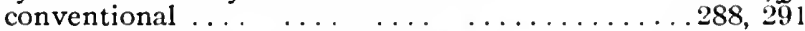

INTERNATIONAL PRIVATE LAW. . . . . . . . 22, 71, 90

INTERPRETATION (Auslegung) . . . . . . . . 88, 89, 90, 91

INTERPRETATIVE METHOD OF STUDY . . . . . . . 304

IZBA (mansio, q. v.).

JAHRBUCH FÜR DOGMATIK ............. 10

JASTROW, religion of the Babylonians and Assyrians.... 41

JOLLY, on code of Manu ...........3, 36,37, 147, 148 die Systematik des indischen Rechts ......... 41 Recht und Sitte ............208, 209, 272, 277

JONES, Sir William, laws of Manu ..............

JUDEX NE EAT ULTRA PETITA PARTIUM ....... 268

JUDICATURE STATUTE $\ldots \ldots \ldots \ldots \ldots \ldots \ldots \ldots \ldots \ldots \ldots$

JUDICIALLY RESPONSIVE ADMINISTRATION OF JUSTICE ..................... $8 s$

JURA IN RE (real rights, q. v.).

JURAL NECESSITY $\ldots \ldots \ldots \ldots \ldots 2,86,216,288,290,291$

JURISPRUDENCE $\ldots \ldots \ldots \ldots \ldots \ldots \ldots \ldots \ldots 22,23,24,25$ methods of literary treatment $\ldots \ldots \ldots \ldots \ldots \ldots, f f$.

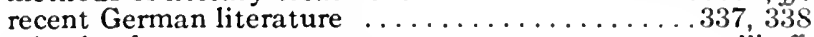
schools of $\ldots \ldots \ldots \ldots \ldots \ldots \ldots \ldots \ldots \ldots \ldots \ldots \ldots \ldots \ldots \ldots \ldots$ iii, $f$

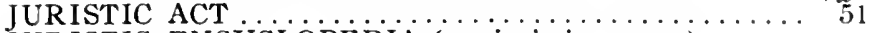

IURISTIC ENCYCLOPEDIA (see juristic survey).

JURISTIC FACT (see fact).

JURISTIC PERSONS 
JURISTIC SURVEY, definition and scope, $v$, xiii, xiv,

divisions xvii, xix, $1,25,26$

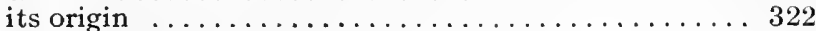

intro. to science of law $\ldots \ldots \ldots \ldots \ldots \ldots \ldots 307,323,327$

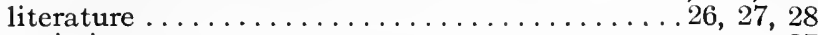

varieties

JURISTIC TRANSLATIONS (into English), kinds ...... xiv

JURISTISCHER LITERATURBERICHT, 288, 308, 309,

$310,312,313,315$

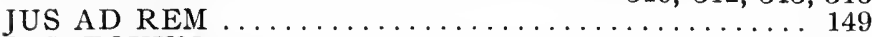

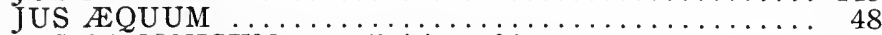

JUS CANONICUM, as a division of law . . . . . . . . 295

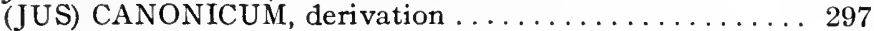

JUS CIVILE ......................... 18

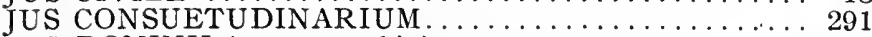

JUS DOMINII (see ownership).

JUS ECCLESIASTICUM COMMUNE . . . . . . . . . . 298

JUS ECCLESIASTICUM PARTICULARE $\ldots \ldots \ldots \ldots \ldots 298$

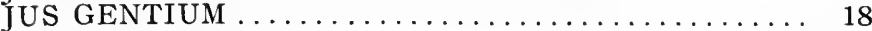

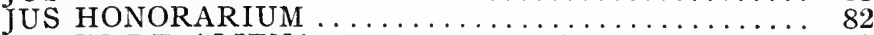

JUS IN RE ALIENA $\ldots \ldots \ldots \ldots \ldots 137,138,139,144,149 f f$.

JUS IN RE PROPRIA $\ldots \ldots \ldots \ldots \ldots \ldots \ldots \ldots \ldots 137,139$

JUS INTER CIVITATES (international law, q. v.).

JUS INTER GENTES (international law, q. v.).

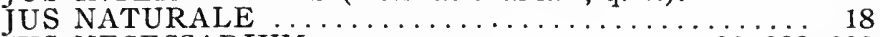

JUS NECESSARIUM . . . . . . . . . . . $86,288,290$

JUS NON SCRIPTUM $\ldots \ldots \ldots \ldots \ldots \ldots \ldots \ldots \ldots 76,77,88$

JUS PRIVATUM (private law, q. v.).

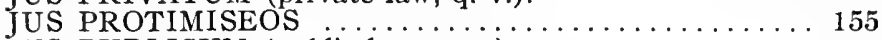

JUS PUBLICUM (public law, q. v.).

JUS RECADENTIA .................... 139

JUS REPR ESENTATIONIS ONNIMOD

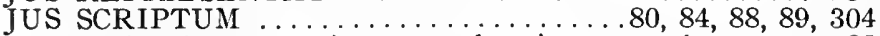
requires interpretation more than jus non scriptum .. 88

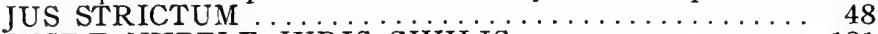

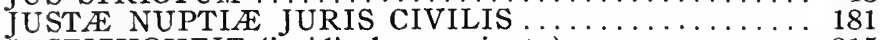

JUSTIZHOHEIT (juridical sovereignty) . . . . . . . 215

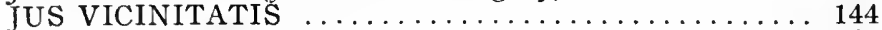

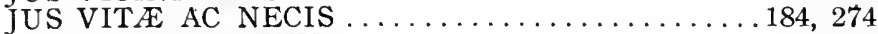

JUS VOLUNTARIUM $\ldots \ldots \ldots \ldots \ldots \ldots \ldots \ldots \ldots \ldots \ldots 29$

KAMMERN FÜR HANDELSSACHEN (commercial courts) 258

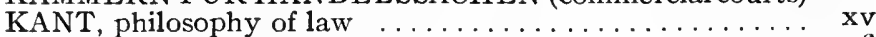
on the necessary form of knowledge $\ldots \ldots \ldots \ldots \ldots \ldots 6$

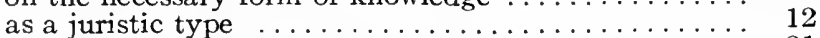

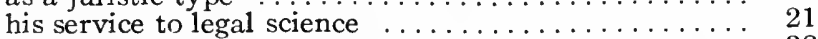

distinction between morals and ethics................ 38

Kritik der prakt. Vernunft $\ldots \ldots \ldots \ldots \ldots \ldots \ldots \ldots 40,41$

Kritik der Urteilskraft $\ldots \ldots \ldots \ldots \ldots \ldots \ldots \ldots \ldots \ldots \ldots, 40$

Einleitung der Metaphysik d. Sitten ............. 41

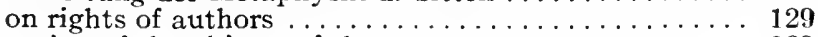

notion of the objects of the state $\ldots \ldots \ldots \ldots \ldots \ldots 223$ 
Page

KARLOWA, röm. Rechtsgeschichte .......... 314

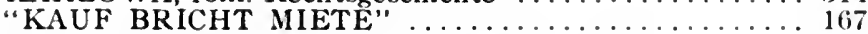

KAUFMANNSGERICHTE (commercial courts) . . . . . 259

KAUFVERTRAG (agreement of sale) $\ldots \ldots \ldots \ldots \ldots \ldots 166$

KAUTELARISCHE RECHTSPFLEGE (prudential admin-

istration of justice; see non-contentious jurisdiction) . . 256

KAUTION ......................... 109

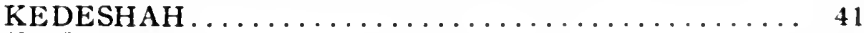

KEYSSNER, das Recht am eigenen Bilde $\ldots \ldots \ldots \ldots 126$

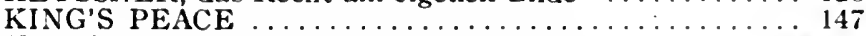

KIN (Sippe), the feud excluded in the $\ldots \ldots \ldots \ldots \ldots 54,55$

was a subdivision of the district-state $\ldots \ldots \ldots \ldots \ldots$

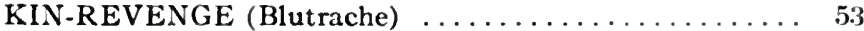

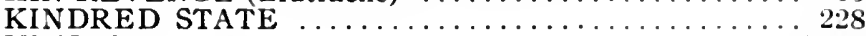

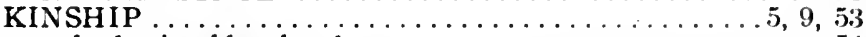

the basis of legal order . . . . . . . . . . 54

KIRCHENHEIM, Zentralblatt für Rechtswissenschaft, 29,

312,315

Lehrb. d. deutschen Staatsrechts . . . . . . . 221

Einführung in d. Verwaltungsrecht $\ldots \ldots \ldots \ldots 242,244$

Verwaltungsrechtspraktikum ..................

KLAGBEANTWORTUNG (answer) ............. 269

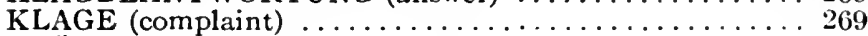

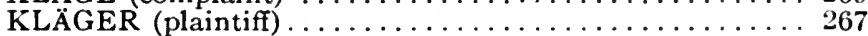

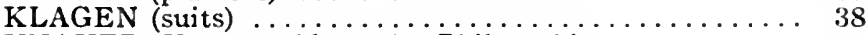

KNAUER, Hauptprobleme der Philosophie . . . . . . . 41

KOHLER, das Recht als Kulturerscheinung......... 2

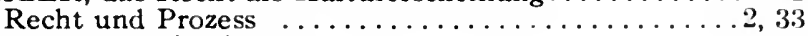

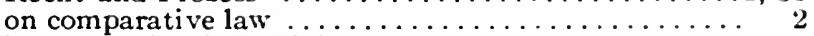

immanent legal principles ............... 10

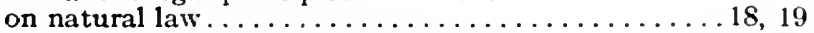

Einfuhrung in die Rechtswissenschaft .......28, 125

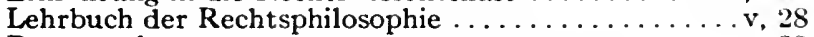

Patentrecht .................... 33

Shakespeare vor dem Forum der Jurisprudenz . . . . . 36

on confusion of law and morals ............ 37

the family as the basis of society $\ldots \ldots \ldots \ldots \ldots \ldots$ 2

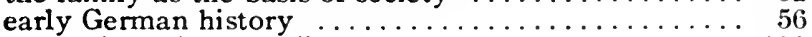

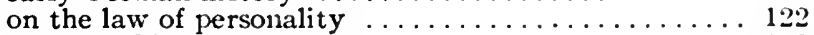

Recht d. Markenschutzes............... 122

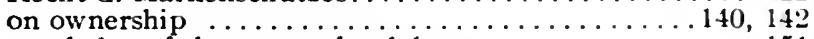

on pledge of the person for debt $\ldots \ldots \ldots \ldots \ldots \ldots \ldots 151$

the place of obligations in civilization $\ldots \ldots \ldots \ldots \ldots 160$

on totemism, etc. ................. 179

on artificial family relationship among the red Indians 187

on blood fraternity ................. 187

the basic conception of civil procedure ......... 266

on private revenge $\ldots \ldots \ldots \ldots \ldots \ldots \ldots \ldots \ldots \ldots$

KOHLER AND PEISER, Hammurabis Gesetz, 4, 155 ,

Babylon, Rechtsleben ......................

KOLLEK'TIVRACHE (collective revenge, q. v.).

KOLONATRECHTE 
KONJEKTURALKRITIK (conjectural criticism, see criticism).

KONKURSORDNUNG (bankruptcy act) . . . . . . 271

KONKURSRECHT (bankruptcy law) $\ldots \ldots \ldots \ldots \ldots \ldots 270$

KONTOKORRENTVERTRAG (agreement relating to ac-

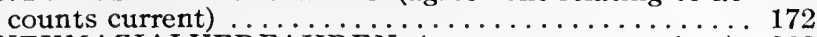
KONTUMAZIALVERFAHREN (contumacy procedure). 268

KORKUNOV, theory of law .............. xi, xvii, 12 KRAUT, Grundriss zu Vorlesungen über d. deutsche Privatrecht $\ldots \ldots \ldots \ldots \ldots \ldots \ldots, 78,84,129,151,187$

KREITTMAYR, on natural law .............. 18 KRIT VIERTELJAHRSSCHRIFT $\ldots \ldots \ldots \ldots \ldots 2,4,56,140$ KRITIK (criticism, q. v.).

KULTURSTAAT

LABAND, das Staatsrecht d. deut. Reiches, 220, 238, 252,

258, 266

LABOULAGE, Geschichte der Vereinigten Staaten ..... 140

LAGERHAUSVERTRAG (warehouse agreement) $\ldots \ldots \ldots 161$

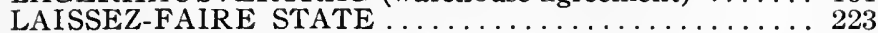

LAMPRECHT, Wirtschaftsleben $\ldots \ldots \ldots \ldots \ldots \ldots \ldots \ldots 56$

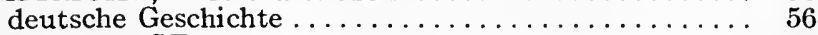

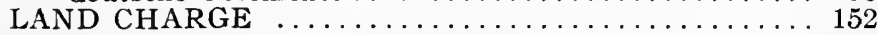

LANDGER ICHTE (provincial courts) $\ldots \ldots \ldots \ldots \ldots \ldots 258$

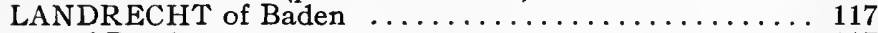

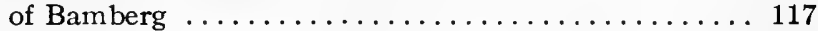
of Bavaria ........18,71,83,84,117, 196, (Lit.) 311

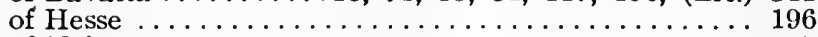

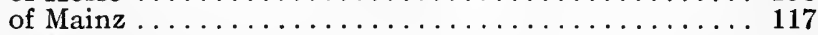

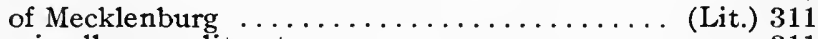
miscellaneous literature $\ldots \ldots \ldots \ldots \ldots \ldots \ldots \ldots \ldots \ldots$ of Prussia, 71, 84, 115, 116, 117, 167, 194, 308, (Lit.) 310

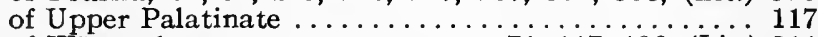
of Würtemberg. $\ldots \ldots \ldots \ldots \ldots \ldots 71,117,196$, (Lit.) 311

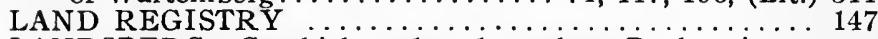

LANDSBERG, Geschichte der deutschen Rechtswissen-

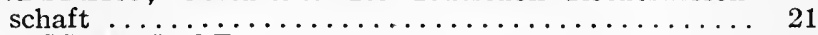

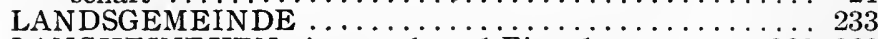

LANGHEINEKEN, Anspruch und Einrede . . . . . 260, 269 der Urteilspruch $\ldots \ldots \ldots \ldots \ldots \ldots \ldots \ldots \ldots \ldots \ldots 269$

LANGUAGE, comparable to customary law . . . . . . 77

LAVELEYE, de la propriété $\ldots \ldots \ldots \ldots \ldots \ldots \ldots, 140,142$

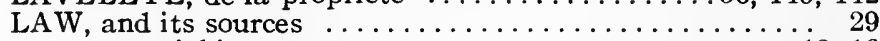

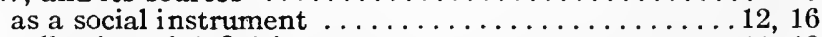
collection of definitions $\ldots \ldots \ldots \ldots \ldots \ldots \ldots \ldots \ldots \ldots \ldots \ldots \ldots$ compared with morals, religion, equity and social con-

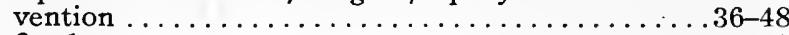

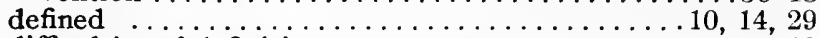
difficulties of definition $\ldots \ldots \ldots \ldots \ldots \ldots \ldots \ldots \ldots, 10$ depends on the authority of the state $\ldots \ldots \ldots \ldots \ldots, 75$ elements of definition $\ldots \ldots \ldots \ldots \ldots \ldots \ldots \ldots \ldots \ldots$ fivefold relation of the state $\ldots \ldots \ldots \ldots \ldots \ldots \ldots \ldots, 62$ in abstract sense $\ldots \ldots \ldots \ldots \ldots \ldots \ldots \ldots \ldots \ldots$ 
is always the expression of human will ......... 74

is that only which the state recognizes as such ..... 63

is modifiable by social development ...........6 61

is solely an institution of the state $\ldots \ldots \ldots \ldots \ldots \ldots$

$i$ ts classification is based on interests . ............. 111

its object is the establishment and maintenance of ex-

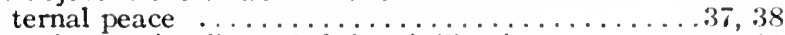

its existence implies a definite civilization ......... 61

may be otherwise classified than as based on interests 292 means and end should be duly porportioned in the legal

system . . . . . . . . . . . . . . . . . . 69

object and essential character............. 10

operates on persons and not things $\ldots \ldots \ldots \ldots \ldots, 31$

political interpretation of $\ldots \ldots \ldots \ldots \ldots \ldots \ldots$ vi

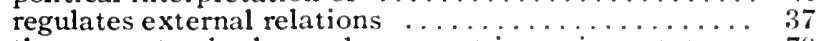

the same standard may be current in various states. 70

the state's recognition of what is law may be direct or indirect

various standards on one subject may be current in the

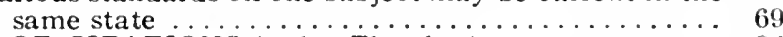

LAW OF CITATIONS (codex Theodos.) . . . . . . . 8:

LA IV OF NATURE SCHOOL ...... $\ldots, f f, 62,65,320,321$

LEBENSGEMEINSCHAFT (conjugal community) ...... 181

LEE, historical jurisprudence .............. 8.3

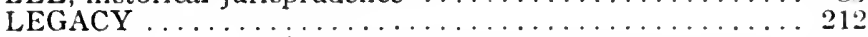

LEGAL ADVANTAGE (Rechtsgut), 35, 42, 65, 68, 80,93 , $94,95,107,122,123,173,273,275,279$

LEGAL EDUCATION, methods (see also Hodegetics) .... . xi

LEGAL INTERPRETATION (see interpretation).

LEGAL NECESSITY (Rechtsnot) . . . . . . . . 62, 147

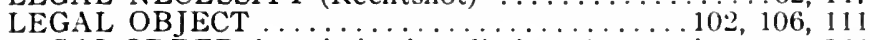

LEGAL ORDER, its mission is to limit and secure interests 324 should duly proportion means and end ........ 69

LEGAL POLICE (non-contentious jurisdiction, q. v.) . . . 261

LEGAL RELATION (see legal rights).

LEGAL RIGHTS, nature of ............... 31

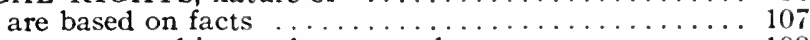

are protected in an abstract and a concrete sense..... 109 interests are the essence of $\ldots \ldots \ldots \ldots \ldots 33,34,35$

LEGAL SENSE . . . . . . . . . . .

LEGAL SERVITUDES . . . . . . . . . . . . 144

LEGAL SUBJECT, is the owner of an interest, 102,106 ,

$111,122,123,146,157,177$

LEGAL SYSTEM, its methods, means and objects univer-

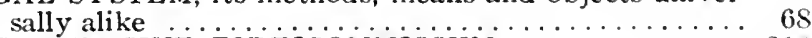

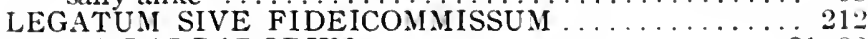

LEGES BARBARORUM ..............

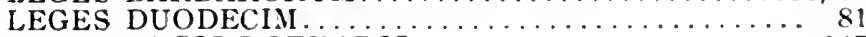

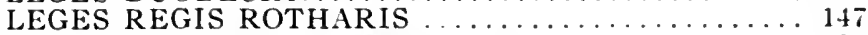

LEGES VISIGOTHORUM $\ldots \ldots \ldots \ldots \ldots \ldots \ldots \ldots \ldots$

LEGISLATION, constitutional provisions in Gernany ... 8.5 creates material of positive law .......... 15 
LEGISLA'TION, in a wide sense $\ldots \ldots \ldots \ldots \ldots \ldots 74$ (note)

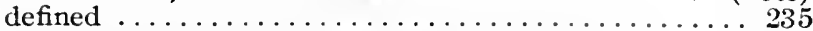
is a declaration by the state of legal standards...... 80 is a division of administrative law . . . . . . . . . 97 is an essential function of the state .............. 80 is jus scriptum even though not written $\ldots \ldots \ldots \ldots .80$ procedure of (steps in making laws) ............ 81 subsequent historically to customary law $\ldots \ldots \ldots \ldots \quad 80$ varieties ........................ 81

LEGISLATIVE POLITY (Gesetzgebungspolitik) ....... 22

LEHENRECHT (law of tenure, see tenure).

LEHENSTAAT (feudal state, q. v.).

LEHMANN, on land registry $\ldots \ldots \ldots \ldots \ldots \ldots \ldots \ldots \ldots$ on Retraktrechte...................... 155 Handels-Wechsel- u- Seerecht . . . . . . . . . . . 302

LEIBZUCHTRECHTE (life pensions) $\ldots \ldots \ldots \ldots \ldots \ldots 154$

LEIHE (commodatum) .................... 169

LEIST, Gräcoitalische Rechtsgeschichte $\ldots \ldots \ldots \ldots \ldots \ldots 77$

LEISTUNG (performance) . . . . . . . . . . . . . . 162

LEONHARD, on Roman law.................. 81

LETTING AND HIRE AGREEMENTS $\ldots \ldots \ldots \ldots \ldots .167$

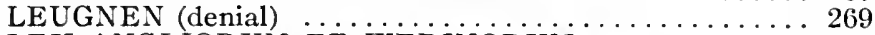

LEX ANGLIORUM ET WERINORUM $\ldots \ldots \ldots \ldots \ldots, 83$

LEX BAJUVARIORUM . . . . . . . . . . . . . . . 82

LEX BURGUNDIONUM $\ldots \ldots \ldots \ldots \ldots \ldots \ldots \ldots \ldots$

LEX COGENS ...................... 180,291

LEX DISPOSITIVA ….................... 91,181

LEX FRANCORUM CHAMAVORUM ........... 83

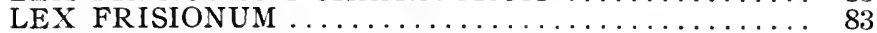

LEX POSTERIOR DEROGAT LEGI PRIORI .......... 90

LEX POSTERIOR GENERALIS NON DEROGAT LEGI PRIORI SPECIALI $\ldots \ldots \ldots \ldots \ldots \ldots \ldots \ldots \ldots, 90 \ldots$

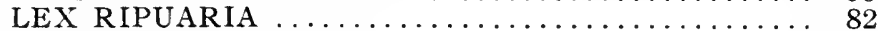

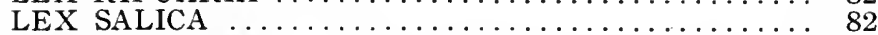

LEX SAXONUM $\ldots \ldots \ldots \ldots \ldots \ldots \ldots \ldots \ldots \ldots \ldots \ldots \ldots \ldots \ldots$

LIABILITY, of husband and wife for debts of the other. . 191 for injuries by third persons ................. 174

LIBERTY ............................... 34

LIBRI FEUDORUM $\ldots \ldots \ldots \ldots \ldots \ldots \ldots \ldots \ldots \ldots \ldots \ldots \ldots \ldots \ldots$

LIEGENSCHAFTEN (immovable things) ............. 107

LILIENTHAL, Militärstrafgerichtsverfahren ........... 282

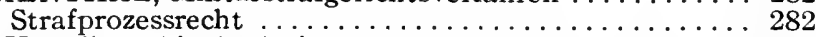

LIOY, philosophie du droit $\ldots \ldots \ldots \ldots \ldots \ldots \ldots \ldots$ xiv

LIPSIUS, rectoral address . . . . . . . 147, 164, 184, 188, 272

LISZT . . . . . . . . . . . . . . . . . . . 13, 15, 33

Lehrbuch des Strafrechts.........33, 49, 274, 277, 281

on collective revenge $\ldots \ldots \ldots \ldots \ldots \ldots \ldots \ldots \ldots 67$

on liability in surgical operations $\ldots \ldots \ldots \ldots \ldots \ldots, 126$

das Völ kerrecht $\ldots \ldots \ldots \ldots \ldots \ldots \ldots \ldots \ldots 287,290$

LISZT AND CRUSEN, die Strafgesetzgebung, etc. . . . . 227

LITERAL CONTRACTS ...................... 164

LITERATURE OF JURISTIC SURVEY (English) $\ldots . .26$

(German) $\ldots \ldots \ldots \ldots \ldots \ldots \ldots \ldots \ldots \ldots \ldots \ldots \ldots \ldots \ldots \ldots \ldots, 28$ 
LITERATURE OF NATURAL LAW (English) ...... 19

LITIS CONTESTATIO, affirmative . ............ 268

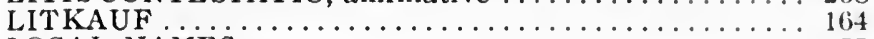

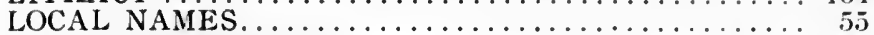

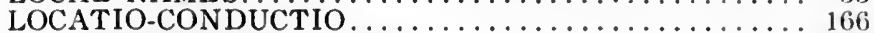

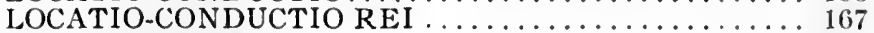

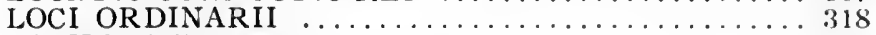

LOCKE, civil government.................. 19

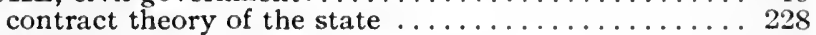

LOKALRECHT (local law) ................ 70

LORIMER, the institutes of law . . . . . . . . . . 19

LÖRSCH AND SCHRÖDER, Urkunden ......... 143, 146

LUBBOCK, the senses and instincts of animals ....... 8

MAFFIA ........................ 63

MAHNVERFAHREN (hortatory procedure) ........ 269

MAIERRECHTE ...................... 153

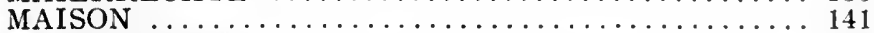

MAJORES DOMUS .................. 83

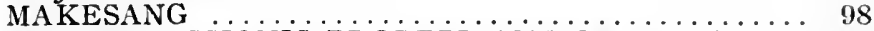

MALUM PASSIONIS PROPTER MALUM ACTIONIS . 274

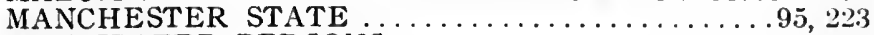

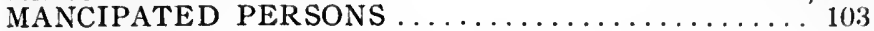

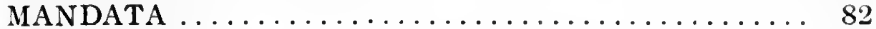

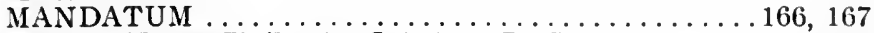

MANDRY, der Zivilrecht. Inhalt d. R.-Gesetze . . . . . 309

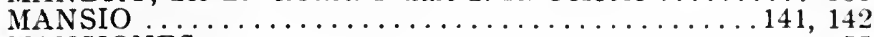

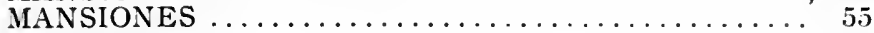

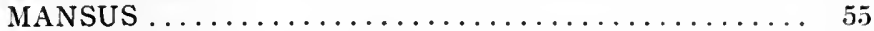

MANU, CODE $\ldots \ldots .3,36,37,47,77,147,148,272,273,277$

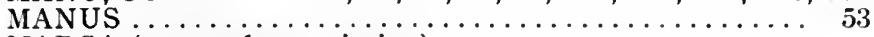

MARCA (see mark association).

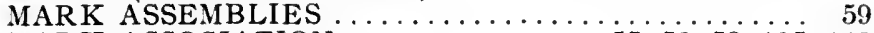

MARK ASSOCIATION $\ldots \ldots \ldots \ldots \ldots \ldots \ldots .55,56,58,105,143$

MARKBY, elements of law $\ldots \ldots \ldots \ldots \ldots \ldots \ldots \ldots, 26$

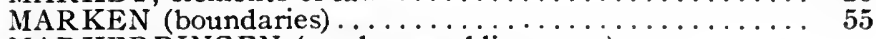

MARKERDINGEN (mark assemblies, q. v.).

MARKGENOSSENSCHAFT (mark association, q. v.).

MARQUARDSEN, Handbuch d. öff. Rechts, 22, 33, 60 , $100,101,220,221,230,235,266,285,286,287,298$

MARRIAGE $\ldots \ldots \ldots \ldots \ldots \ldots \ldots \ldots \ldots \ldots \ldots \ldots \ldots \ldots \ldots \ldots$. produced no proprietary effect, in Roman law. 192, 193 proprietary effect of, in German law ........... 193

MARTENS, international law . . . . . . . . . . 287

MATERIALVERTR ÄGE (substantive agreements) . . . . 164 MATRIMONIAL RÉGIME . . . . 181, 189, 191, 192, 194 ff. MATRIMONIUM JURIS GENTIUM $\ldots \ldots \ldots \ldots \ldots 181$

MAURER, Geschichte der Markenverfassung ........ 55

Einleitung zur Geschichte der Mark-(etc.), Verfassung 55

MEDICO-LEGAL SCIENCE ................... 315 MEITZEN, der Älteste Anbau der Deutschen . . . . . . . . 55,56 MERCANTILE EMPLOYMENT AGREEMENTS . . . . 171 MERCANTILE ORDERS ................ 172 
MERCANTILE POWER OF AGENCY .......... 171

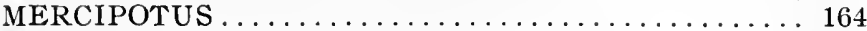

MERGER ........................ 160

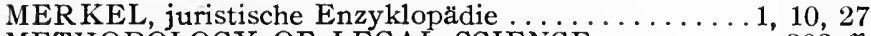

METHODOLOGY OF LEGAL SCIENCE $\ldots \ldots \ldots . .303 f f$. METHODS OF EXPRESSION OF THE POWER OF

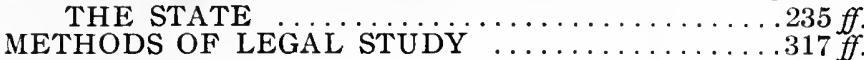

MEYER, Lehrb. d. deutschen Verwaltungsrechts, 221, 242, 286

MIETE (ordinary lease) . . . . . . . . . . . . . . 160

MILITÄRHOHEIT (military sovereignty) . . . . . . . 215

MILITARY LAW, in some form necessary to the state, 97, 224

MILITARY POWER, indispensable to the state.......66

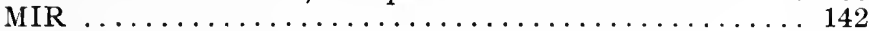

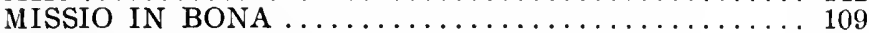

MITGIFT (dowry) . . . . . . . . . . . . . . . . . . 193

MIXED LAW OF PERSONS AND THINGS ....... 191

MOBILIARGEMEINSCHAFT (community of movables) . 196

MOHL, Enzyk. d. Staatswissenschaften ........221, 222

MOMMSEN, röm. Staatsrecht . . . . . . . . . . 232, 233

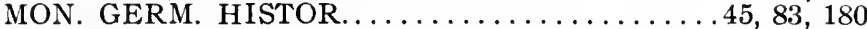

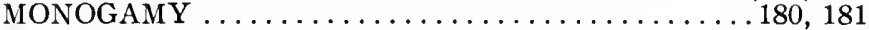

MONTESQUIEU, definition of law ........... 11

on England's suicide rate $\ldots \ldots \ldots \ldots \ldots \ldots \ldots, 68$

MORAL PERSONS (see juristic persons) . . . . . . . . 104

MORALISTIC SCHOOL (see also jurisprudence and schools

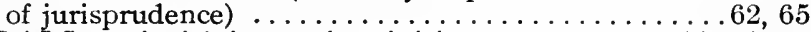

MORALS, deal with internal activities $\ldots \ldots \ldots \ldots 29,38,42$ distinguished from ethics $\ldots \ldots \ldots \ldots \ldots \ldots \ldots \ldots \ldots$ essentially influential in a legal system $\ldots \ldots \ldots \ldots 67$ not confined to subjective states $\ldots \ldots \ldots \ldots \ldots \ldots, 39$

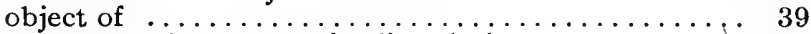
rather than law, secure family relations $\ldots \ldots \ldots \ldots, 177$

MORGANATIC MARRIAGE .............. 181

MORT, le, saisit le vif...................... 202

MOS DOCENDI GALLICUS $\ldots \ldots \ldots \ldots \ldots . \ldots 319,320,322$

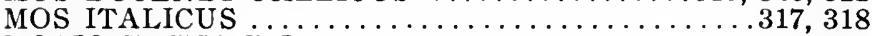

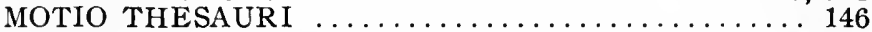

MOTIVES, are created by legal rules $\ldots \ldots \ldots \ldots \ldots \ldots \ldots, 51$

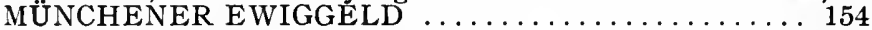

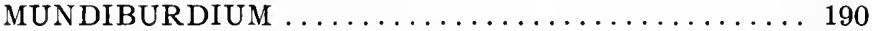

MUNZINGER, erbrechtliche studien $\ldots \ldots \ldots \ldots \ldots 40,208$

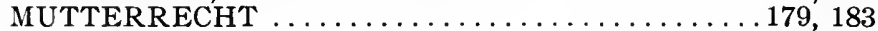

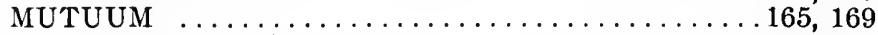

NACHLASSGERICHT (inheritance court) . . . . . . . 261

NACHTIGALL, in Rundschau, on African polygany $.179,180$

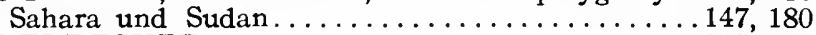

NÄHERRECHTE . . . . . . . . . . . . . . . . 145, 155

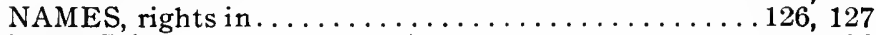

NARADA . . . . . . . . . . . . . . . . . . 36

NASSE, the agricultural community of the Middle Ages .. 56 village communities $\ldots \ldots \ldots \ldots \ldots \ldots \ldots \ldots \ldots \ldots$ 
IATIOYAI CHARACTER as a legal influence ....... Page

NATURALES OBLIGATIÓNES $\ldots \ldots \ldots \ldots \ldots \ldots \ldots 7,160$

NATURAL LAW (see school of natural law), now dis-

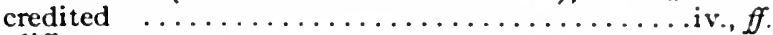

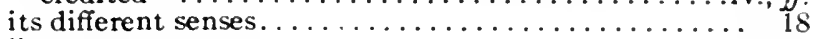

literature ..................... 19

its impracticability ..................... 20

not to be confused with conformability of law in

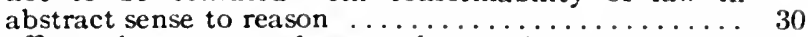

affirms that concrete laws conform to human reason. 62

overthrown by the historical school............. 19

NATURRECHT (natural law, q. v.).

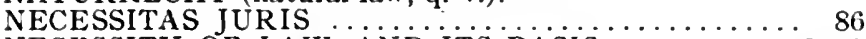

NECESSITY OF LAW, AND ITS BASIS ........

NEGATIVE ACTS, may produce rights $\ldots \ldots \ldots \ldots \ldots 165$

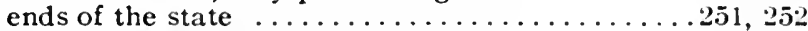

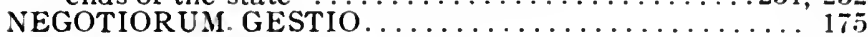

NEMO JUDEX SINE ACTORE ............. 268

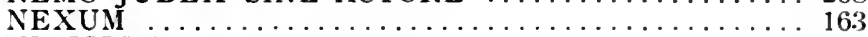

NIESSBRA $\mathrm{UCH}$, usufruct $\ldots \ldots \ldots \ldots \ldots \ldots \ldots \ldots \ldots \ldots 150$

NOBILITY, law relating to the $\ldots \ldots \ldots \ldots \ldots \ldots \ldots \ldots 87$

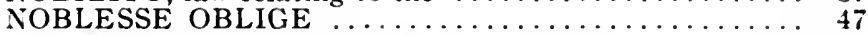

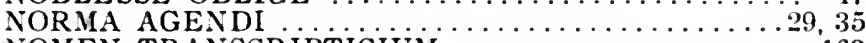

NOMEN TRANSCRIPTICIUM $\ldots \ldots \ldots \ldots \ldots \ldots \ldots \ldots \ldots$

NON-CONTENTIOUS JURISDICTION, $88,200,20 \overline{7}$,

NOTERBEN (compulsory heirs)

NOTSTAND (right of necessity, q. v.).

NOT WEHR (necessary defense, see self-defense).

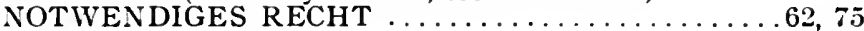

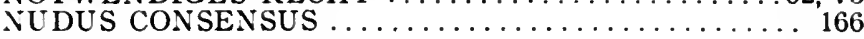

$\mathrm{OATH}$, the, as a religious idea $\ldots \ldots \ldots \ldots \ldots \ldots \ldots 45,68$

OBERLANDESGERICHT (provincial court of appeal),

OBERVORMUNDSCHAFTSBEHORDEN (communal 258,270

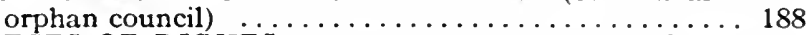

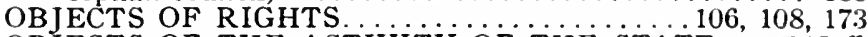

OBJECTS OF THE ACTIVITY OF THE STATE ...245 ff.

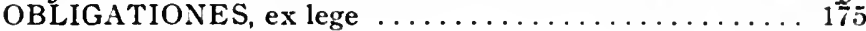

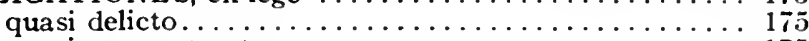

quasi ex contractu................. 175

OBLIGATIONS, law of . . . . . indicate a high stage of culture $\ldots \ldots \ldots \ldots \ldots \ldots 160$ involve only particular personal relations and not the

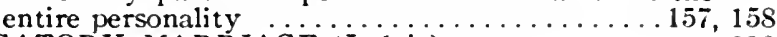

OBLIGATORY MARRIAGE (Judaic) $\ldots \ldots \ldots \ldots \ldots \ldots .202$

OCCUPATIO ...................... 145

Bellica....................... 146

OCEAN CARRIAGE AGREEMENTS .......... 171

OCEAN HIRE AGREEMENTS $\ldots \ldots \ldots \ldots \ldots \ldots \ldots \ldots \ldots 171$

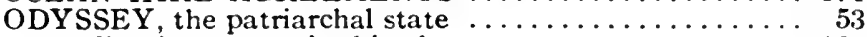

obligations recognized in the ............. 160 
OERTMANN, Windscheid's Gesammelte Reden . . . . . 12, 19

OFFENE HANDELSGESELLSCHAFTEN (unlimited

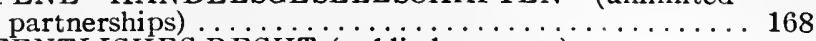
ÖFFENTLICHES RECHT (public law, q. v.).

OFFICIAL RIGHTS, belong to public law . . . . . . . . 99 may also be regarded as transferred by the state ..... 100 "OLD MAN'S PART" .................... 150 ONCKEN, die Staatslehre des Aristotoles . . . . . 7, 9, 67,140

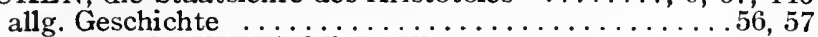

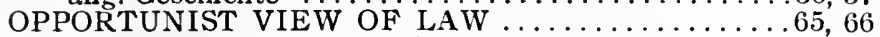

ORDERPAPIERE (mercantile orders, instruments drawn

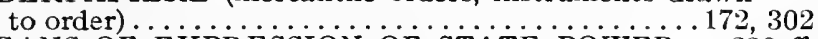
ORGANS OF EXPRESSION OF STATE POWER . $230 f f$.

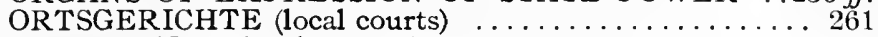
ORTSUSANCE (local custom) .................... 70 OWNERSHIP, consists in complete legal control of a

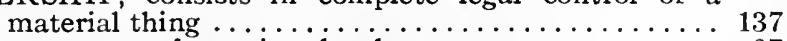
is a necessary factor in a legal system . . . . . . . . 67 its nature and historical foundations ..............

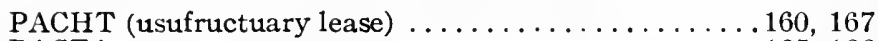

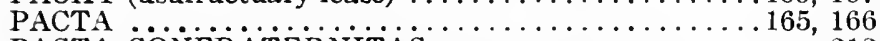
PACTA CONFRATER

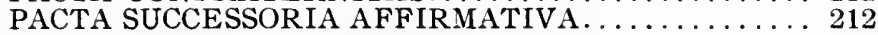
PACTA SUCCESSORIA RENUNCIATORIA $\ldots \ldots \ldots \ldots .212$ PACTUS ALAMANORUM $\ldots \ldots \ldots \ldots \ldots \ldots \ldots \ldots \ldots . \ldots \ldots 2$ PADERBORN SYNOD ................... 44

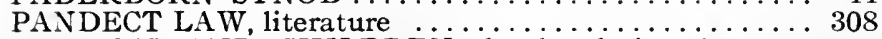

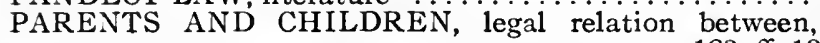
$183 \mathrm{ff}, 198 \mathrm{ff}$.

PARTEIF ÄHIGKEIT (capacity of parties) ......... 267 PARTIKULÄRE GÜTERGEMEINSCHAFT (particular community of goods) $\ldots \ldots \ldots \ldots \ldots \ldots \ldots \ldots \ldots \ldots \ldots$

PARTIKULARES RECHT (particular law) ............. 70

PARTITION OF THE LAW-MAKING FUNCTION .... 58

PARTNERSHIP AGREEMENTS .............. 168

PASSENGER CARRIAGE AGREEMENTS $\ldots \ldots \ldots \ldots 171$

PATENTS OF INVENTION $\ldots \ldots \ldots \ldots \ldots \ldots \ldots \ldots \ldots \ldots \ldots \ldots \ldots$

PATRIA POTESTAS $\ldots \ldots \ldots \ldots \ldots \ldots \ldots \ldots 53,180,184,185$

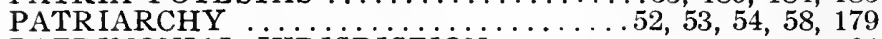

PATRIMONIAL JÜRISDICTION $\ldots \ldots \ldots \ldots \ldots \ldots \ldots \ldots 64$

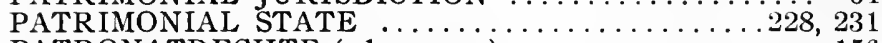

PATRONATRECHTE (advowsons) $\ldots \ldots \ldots \ldots \ldots \ldots \ldots 156$

PATTEE, the essential nature of law $\ldots \ldots \ldots \ldots \ldots \ldots \ldots \ldots . \ldots \ldots$

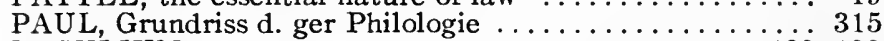

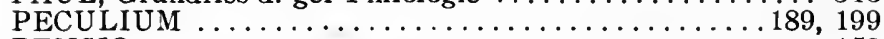

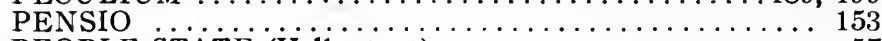

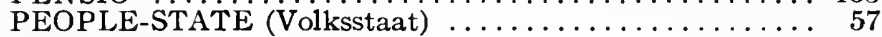

PERCEPTION, law operates on this faculty .....50, 272,274

PERPETUAL CHARGES . . . . . . . . . . . . . 149, 153

PERSON, as a thing has no rights $\ldots \ldots \ldots \ldots \ldots \ldots \ldots \ldots \ldots \ldots \ldots \ldots, 183,198$ is any entity which may own an interest . . . . . . 102 personal relations, q. v. 
PERSONAL RELATIONS, form family law and law of

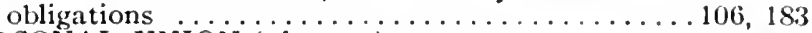

PERSONAL UNION (of states) ............... 229

PERSONALITY, classification of rights of . . . . . . . 123 is synonymous with capacity for rights . . . . . . 10:3

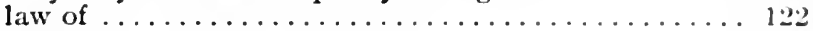
measures for legal protection of . . . . . . . 123 rights of, in detail ................. 1:5 was completely involved in the primitive law of obligations

PERSONALITÄTSSYSTEM (principle of personality) $\ldots 7$ 72

PERSONENHOHEIT (sovereignty over persons) . . . . 215

PERSONNICHKEITSRECHTE (rights in one's own person, see personality), are a division of the law of things $\ldots \ldots \ldots \ldots \ldots \ldots \ldots \ldots \ldots \ldots \ldots \ldots \ldots \ldots$

PFANDRECHTE (pledge-rights, q. v.).

PFLICHTTEIL (compulsory portion) . . . . . . . . . . 210

PFRÜNDNERRECHTE (prebendiary rights, q. v.).

PHILOSOPHY OF LAW $\ldots$. .iii., $f f ., 2,21,22,23,25,315,322$

PHOTOGRAPHS, proprietary use protected . . . . . . 13.3

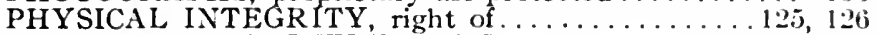

PHYSIOGRAPHIC INFLUENCES, as sources of law . . . 68

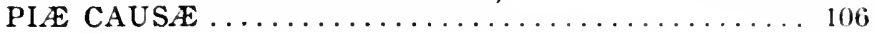

PIERANTONI, the advance of international law ...... 287

PIGNUS (see pledge rights).

PLACETUM REGIUM ..................... 296

PLEBISCITA ...................... 81

PLEDGE RIGHTS $\ldots \ldots \ldots \ldots \ldots 150,151,152,165,169,170$

PLURAL STATES $\ldots \ldots \ldots \ldots \ldots \ldots \ldots \ldots \ldots \ldots \ldots \ldots \ldots$

P(ENE SECUNDARUM NUPTIARUM . . . . . . . 202

POINT (Peint, Bannt) ................. 143

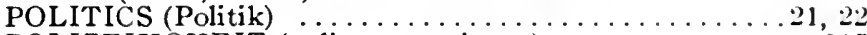

POLIZEIHOHEIT (police sovereignty) $\ldots \ldots \ldots \ldots \ldots 215$

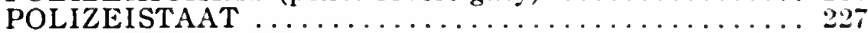

POLYGAMIA SIMULTANEA .............. 180

POSITIVE ENDS OF THE STATE . . . . . . . $25 \mathrm{i}, 252$

POSITIVE LAW, as the basis of legal science $\ldots \ldots \ldots \ldots$

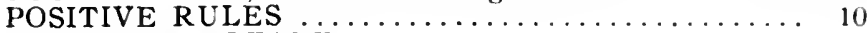

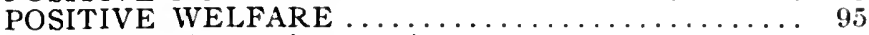

POSSESSIO (possession, q. v.).

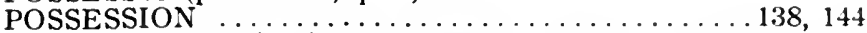

POST, Einleitung in eine Naturwissenschaft des Rechts .. 2

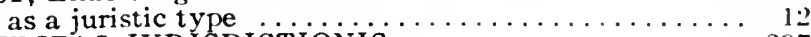

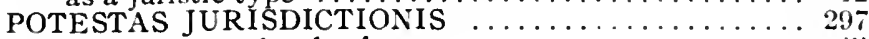

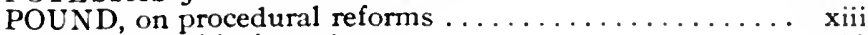
outlines of jurisprudence $\ldots \ldots \ldots \ldots \ldots \ldots \ldots \ldots \ldots$

a new school of jurists $\ldots \ldots \ldots \ldots \ldots \ldots \ldots \ldots \ldots \ldots$

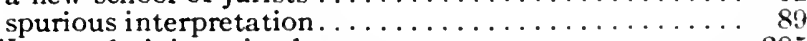

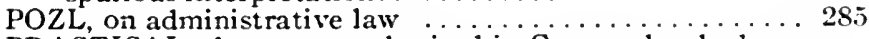

PRACTICAL, the, now emphasized in German legal education ..............................

PRACTICAL SCHOOL, the, (see also jurisprudence and schools of jurisprudence) 
PRAEDIA DOMINANTIA ................ 151

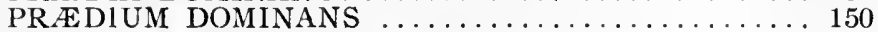

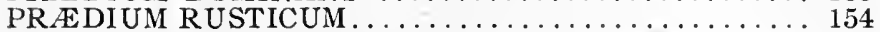

PRÆDIUM SERVIENS ................. 150

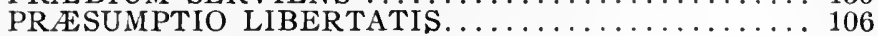

PR ESUMPTIONES JURIS $\ldots \ldots \ldots \ldots \ldots \ldots \ldots \ldots \ldots \ldots \ldots .88$

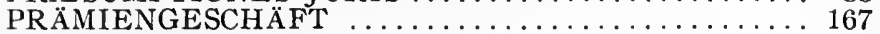

PRANTL, writing on comparative law $\ldots \ldots \ldots \ldots \ldots \ldots 2$

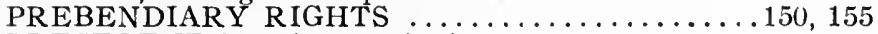

PRECEDENT (see also case law).

as a species of legislation $\ldots \ldots \ldots \ldots \ldots \ldots \ldots \ldots \ldots \ldots$

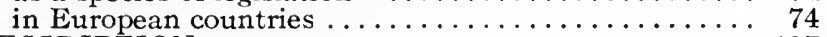

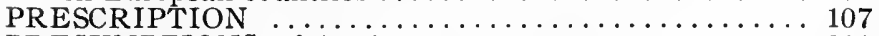

PRESUMPTIONS, of death ................ 202

PREVENTIVE JUSTICE (see non-contentious jurisdic-

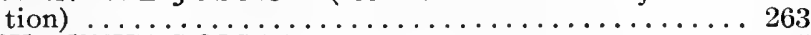

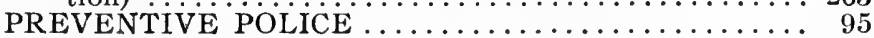

PRIMOGENITURE ..................... 209

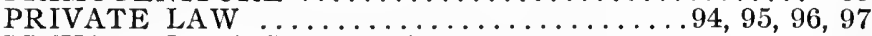

PRIVATE LAW (German), literature ............. 309 exists, at least in rudimentary form, in every state. . . 97 importance minimized in some lower civilizations . . .98, 99 defimited from public law by interests .......... 99 presents greater diversities than public law ........ 100

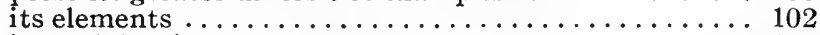

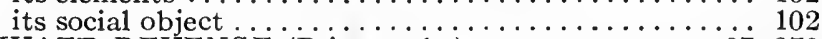

PRIVATE REVENGE (Privatrache) $\therefore \ldots \ldots \ldots \ldots \ldots 67,272$

PRIVILEGED JURISDICTION OF CORPORATIONS . 64

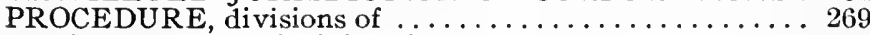

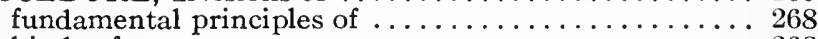

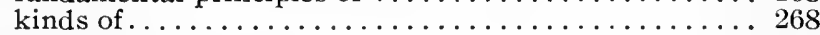

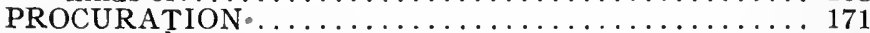

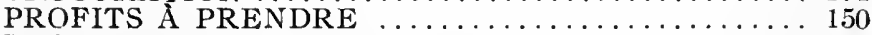

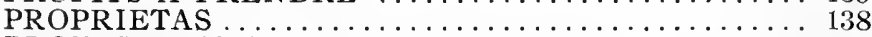

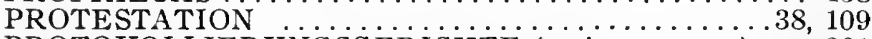

PROTOKOLLIERUNGSGERICHTE (registry courts) ... 261

PROVINCE OF JURISTIC SURVEY (see also juristic

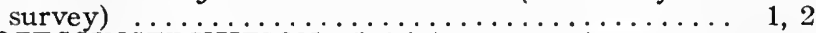

PROZESSINSTRUKTIOON (initial process, introductory

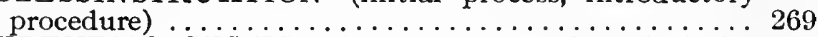

PRUDENTIAL JUSTICE (see non-contentious jurisdiction).

PUBLIC LAW ............................. confused with private law in undeveloped civiliza-

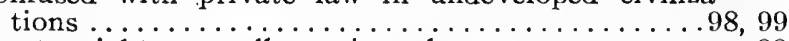
creates rights, as well as private law .......... 99 German .......................... its scope cannot be abstractly set off . . . . . . 97 may coincide with private law in the protection of cer-

tain interests . . . . . . . . . . . . reception of, by another state, a matter of difficulty

supreme over private interests . . . . . . . . . 101 the terminology of its divisions $\ldots \ldots \ldots \ldots \ldots 94,95,96$ 
PUBLISHERS' AGREEMENTS

PUCHTA, das Gewohnheitsrecht

QUARTA FALCIDIA $\ldots \ldots \ldots \ldots \ldots \ldots \ldots \ldots \ldots \ldots \ldots$

QUESTIO FACTI $\ldots \ldots \ldots \ldots \ldots \ldots \ldots \ldots \ldots \ldots \ldots \ldots \ldots .88$

QUESTIO' JURIS $\ldots \ldots \ldots \ldots \ldots \ldots \ldots \ldots \ldots \ldots \ldots \ldots \ldots . . \ldots \ldots$

QUOD NON EST ACTUM, non est in mundo........... 268

RAMDOHR, on rights in names $\ldots \ldots \ldots \ldots \ldots \ldots \ldots$

RANK, as affecting capacity ................ 103

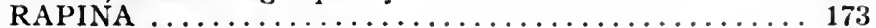

REAL COMMUNITIES (see mark associations) ....... 105

REAL CONTRACTS. .................... 165

REALGEMEINDEN (real communities, see mark asso-

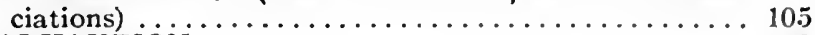

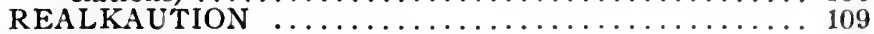

REALLASTEN (perpetual charges, q. v.).

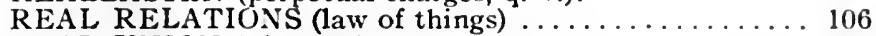

REAL UNION (of states) ..................29

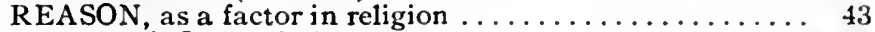
as an influence in law ............ in the domain of morals. . . . . . . . . . . . . . . 40

RECHT AN DER EIGENEN SACHE (see ownership).

RECHT, derivation ................... 29

RECHT IM OBJEKTIVEN SINNE $\ldots \ldots \ldots \ldots \ldots \ldots \ldots, 29$

RECHT IM SUBJEKTIVEN SINNE $\ldots \ldots \ldots \ldots \ldots \ldots, 1$

RECHTSAN IVENDUNG (application of legal rules, q. v.).

RECHTSENZYKLOPÄDIE (juristic survey, q. v.).

RECHTSFALL (case, legal controversy) ............ sS

RECHTSGESCHÄFTE (acts in the law) $\ldots \ldots \ldots \ldots \ldots 120$

RECHTSGUT (legal advantage, q. v.).

RECHTSHILFE (legal redress) … . . . . . . . . 259

RECHTSINSTITUT (legal institution) $\ldots \ldots \ldots \ldots \ldots \ldots, 31$

RECHTSMITTEL (appeal and error) ............ 270

RECHTSMITTELVERFAHREN (appellate procedure) . 269

RECHTSNOT (legal necessity) $\ldots \ldots \ldots \ldots \ldots \ldots \ldots \ldots \ldots . \ldots \ldots$

RECHTSNOTWENDIGKEIT (jural necessity, q. v.).

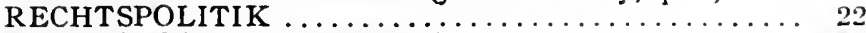

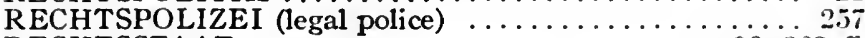

RECHTSSTAAT .....................

RECHTSVERHALTNIS (legal relation, see legal rights).

RECHTSWISSENSCHAFT (science of law, q. v.) . . . . 22

REFERIERKUNST $\ldots \ldots \ldots \ldots \ldots \ldots \ldots \ldots \ldots \ldots \ldots . \ldots \ldots$

REGELSBERGER, Pandekten $\ldots \ldots \ldots \ldots \ldots \ldots \ldots \ldots 90$

REHM, modernes Fürstenrecht $\ldots \ldots \ldots \ldots \ldots \ldots \ldots \ldots .293$

REICHSGERICHT (Supreme Court) . . . . . . . . 258

REI VINDICATIO ....................... 144

REKLAMESCHWINDEL (unlawful puffing) . . . . . . 1 29

REKTAPAPIERE ...................... 172

RELATIONS OF FACT $\ldots 11,30,31,80,88,99,100,102,106$

RELEASE ........................ 160

RELIGION, deals with internal states.......... $42-46$ 
RELIGION, may oppose law . . . . . . . . . . 43, 44

RELIGIOUS ASSOCIATIONS, are subject to civil law . . 45

RENAISSANCE, its influence on the law . . . . . . . . 318

RENTENSCHULD (annuity charge, see pledge rights).

REPLIK (replication) $\ldots \ldots \ldots \ldots \ldots \ldots \ldots \ldots \ldots \ldots \ldots \ldots$

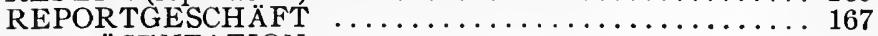

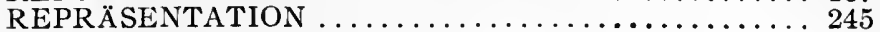

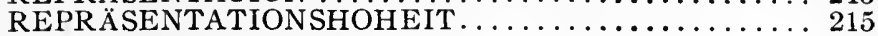

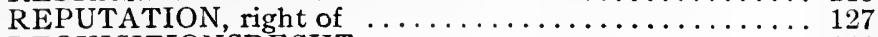

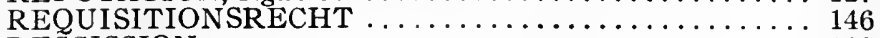

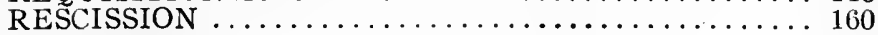

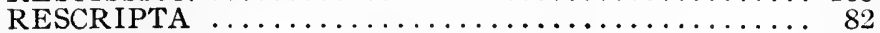

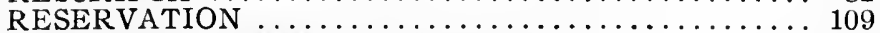

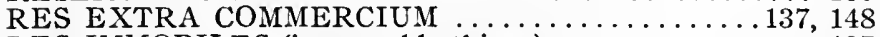

RES IMMOBILES (immovable things) $\ldots \ldots \ldots \ldots \ldots \ldots \ldots 10 \ldots \ldots$

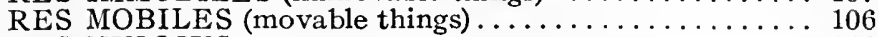

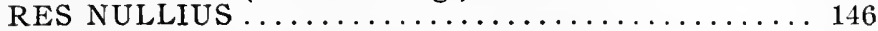

RESPONSA PRUDENTIUM ................ 82

RESPONSORISCH-JUSTIZIELL RECHTSPFLEGE (de-

cisional administration of justice) . . . . . . .

RES SESE MOVENTES (see things).

RESTRICTIVE INTERPRETATION (see interpretation).

RETALIATION, in primitive law $\ldots \ldots \ldots \ldots \ldots \ldots \ldots 227$

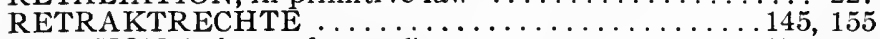

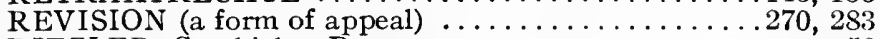

RIEZLER, Geschichte Bayerns $\ldots \ldots \ldots \ldots \ldots \ldots \ldots \ldots 56$

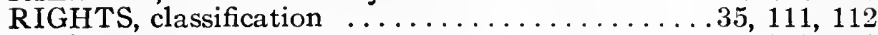

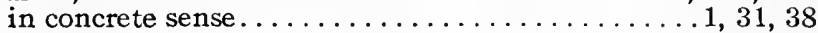

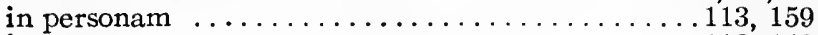

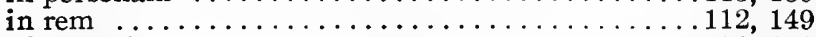

of necessity $\ldots \ldots \ldots \ldots \ldots \ldots \ldots \ldots \ldots \ldots \ldots \ldots \ldots \ldots \ldots \ldots$

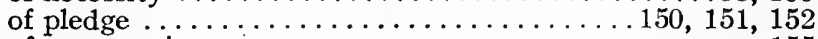

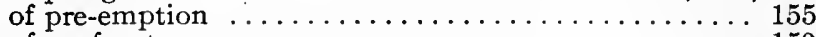

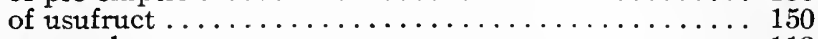

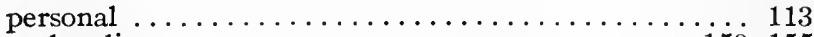

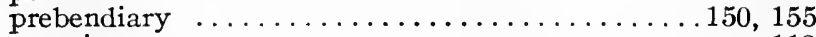

proprietary . . . . . . . . . . . . . . . 113

real $\ldots \ldots \ldots \ldots \ldots \ldots 123,133,136 \ldots f ., 149 \not f ., 159,165$

RINDFLEISCH, neo-vitalismus $\ldots \ldots \ldots \ldots \ldots \ldots \ldots \ldots, 7$

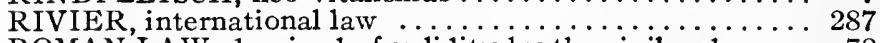

ROMAN LAW, deprived of validity by the civil code ... 78 its reception in Germany $\ldots \ldots \ldots$ xi., $70,78,82,114,115$

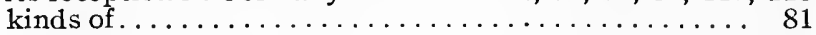

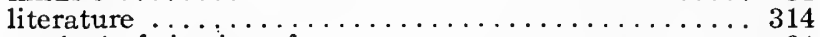

method of citation of $\ldots \ldots \ldots \ldots \ldots \ldots \ldots \ldots \ldots \ldots$

public, not received in Germany ............ 325

the effort to abolish it in Germany ........... 115

ROMANTIC SCHOOL (see jurisprudence, and schools of

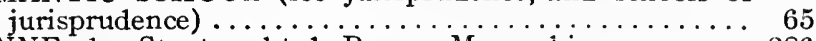

RONNE, das Staatsrecht d. Preuss. Monarchie . . . . . . . 286

ROSCHER, Ansichten der Volkswirtschaft ......... 56

ROSS, early history of land-holding $\ldots \ldots \ldots \ldots \ldots \ldots \ldots \ldots \ldots \ldots \ldots$

ROTH, deutsches Privatrecht $\ldots \ldots \ldots \ldots \ldots \ldots \ldots \ldots .90$ 
Page

ROUSSEAU, contract theory of the state $\ldots \ldots \ldots \ldots 28$

RÜCKTRITT VOM VERTRAG (rescission, q. v.).

RUNDSCHAU (deutsche) …................. 179

RUNNING ACCOUNT AGREEIENTS ...........

SACHHOHEIT (sovereignty over things) $\ldots \ldots \ldots \ldots \ldots 215$

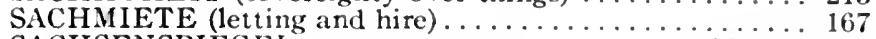

SACHSENSPIEGEL ...............

SACRED BOOKS OF THE EAST ................... 3

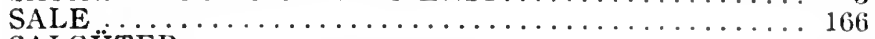

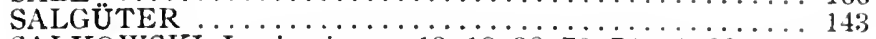

SALKOWSKI, Institutionen, $13,18,38,73,78,81,88,102$, $106,139,149,157,166,173,175,202,208,211$

SALMOND, jurisprudence ............. 1, 23, 26, 113, 163

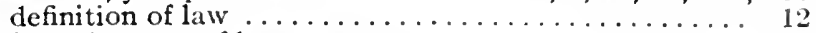

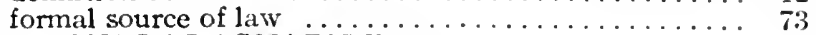

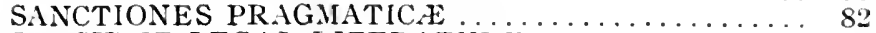

SANSKRIT LEGAL LITERATURE .......... 3

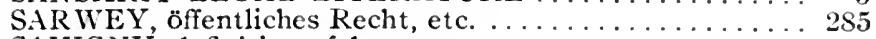

SAVIGNY, definition of law ......................... 11

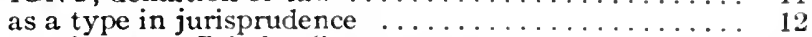

beruf unserer Zeit für Gesetzgebung . . . . . . . . . 19

system des heutigen röm. Rechts .......90, 144, 320

Geschichte d. röm. Rechts im Mittelalter ........ 317

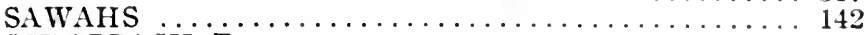

SCHAPPACH, Forstwesen .................. 251

SCHATZHEBERECHT (law of treasure-trove) . . . . . . 146

SCHEIL, délégation en Perse .............. 4

SCHIEDSRICHTERLICHES VERFAHREN (procedure

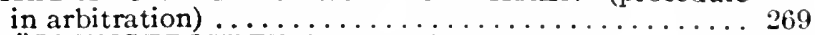

SCHÖFFENGERICHTE (assessors' courts) . . . . 25. $\dot{5}, 281$

SCHOFFENSPRÜCHE.................

SCHONBERG, Handbuch d. Polit. Okonomie ........... 244

Handbuch der Staatswissenschaften ......... 251

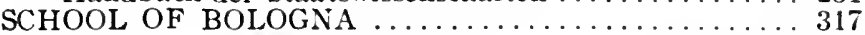

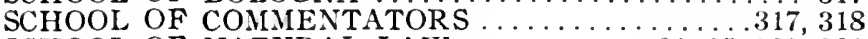

SCHOOL OF NATURAL LAIV . . . . . . 62, 65, 320, 321

SCHOOLS OF JURISPRUDENCE, iii, ff., 10, 12, 62, 65, $319 \mathrm{ff}$.

SCHOULER, ideals of the republic ............ 19

SCHRIFTEN WECHSEL (written pleadings) . . . . . 269

SCHRODER, deutsche Rechtsgeschichte ......56, 84,314 die Franken und ihr Recht .............. 143

die Ausbreitung der Salischen Franken......... 143

on the Feldgemeinschaft ............... 143

Geschich te des ehelichen Gaterrechts . . . . . . . 196

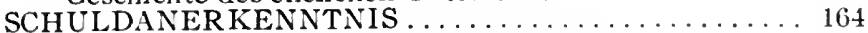

SCHULDVERHÄLTNIS (obligatory relation) . . . . . 159

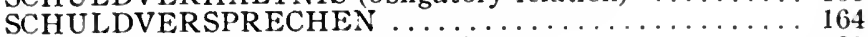

SCHULTE, deutsche Rechtsgeschichte ........... 83

Lehrbuch d. K. u. Ev. Kirchenrechts ... . . . 186, 296

Lehrb. d. deutschen R. u. Rechtsgeschichte ....... 314

SCHULZE, Lehrb. d. deutschen Staatsrechts . . . . . .2.21, 285

SCHULZE-GÄVERNITZ, das deutsche Fürstenrecht . . . 293 
SCHUSTER, principles of German civil law, xv, 113, 144,

SCHUTZGENOSSEN

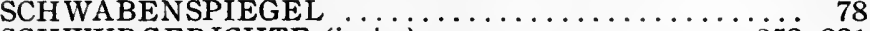

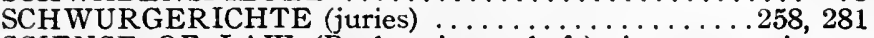

SCIENCE OF LAW (Rechtswissenschaft), is systematic

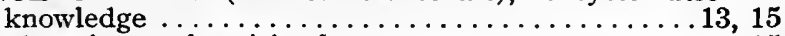

as the science of positive law ............ 15

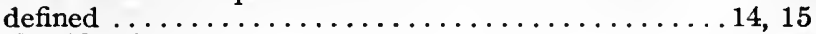

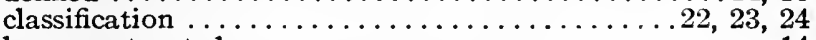

how constructed ................... 14

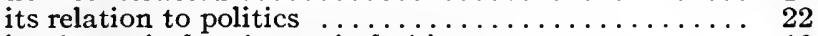

its theoretical and practical objects $\ldots \ldots \ldots \ldots \ldots \ldots, 16$

SCIENCE OF STATE (Staatswissenschaft) $\ldots \ldots \ldots \ldots .21$

SECURITIES (Wertpapiere, q. v.- - negotiable instruments

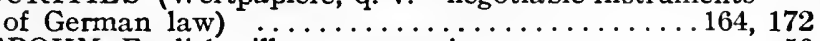

SEEBOHM, English village community ......... 56 tribal custom in Anglo-Saxon law ........... 56 SELBSTHILFE (self-help, q. v.).

SELECT ESSAYS IN ANGLO-AMERICAN HISTORY . . viii SELF-DEFENSE . . . . . . . . . . . . 38, 109, 123, 126, 147 SELF-HELP $\ldots \ldots \ldots \ldots \ldots \ldots \ldots \ldots \ldots \ldots 38,123,144,147$

SEMPER, die Paloinseln $\ldots \ldots \ldots \ldots \ldots \ldots \ldots \ldots \ldots \ldots$

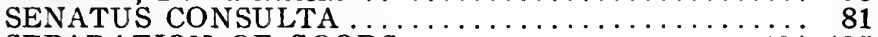

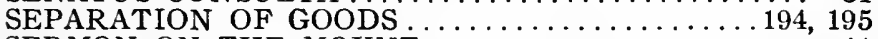

SERMON ON THE MOUNT $\ldots \ldots \ldots \ldots \ldots \ldots \ldots \ldots \ldots 41$

SERVITUDES $\ldots \ldots \ldots \ldots \ldots \ldots \ldots \ldots \ldots \ldots \ldots \ldots \ldots \ldots \ldots \ldots \ldots$

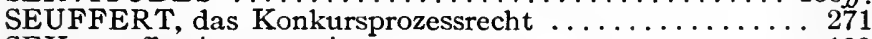

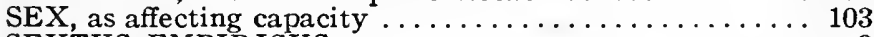

SEXTUS EMPIRICUS .................. 9

SEYDEL, Bayer. Staatsrecht. . . . . . . . . . . 286

Grundzüge einer allg. Staatslehre $\ldots \ldots \ldots \ldots \ldots \ldots \ldots 286$

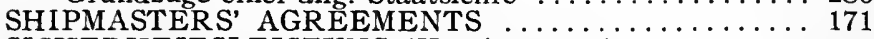

SICHERHEITSLEISTUNG (Kaution, q. v.).

SICHERUNGSHYPOTHEK (see pledge rights).

SICKEL, early Germanic history (monograph) . . . . . . 57

SIPPE (kin, q. v.).

SITTLICH KEIT (morals, q. v.).

SITZUNGSPOLIZEI .................... 259

SLAVERY $\ldots \ldots \ldots \ldots \ldots \ldots \ldots \ldots \ldots \ldots 6,106,125,158,249$

SMALL, the meaning of social science $\ldots \ldots \ldots \ldots \ldots \ldots$ viii

SMITH, GEO. H., the law of private right $\ldots \ldots \ldots \ldots \ldots \ldots 19$

SMITH, early religion of the Semites ............ 41

SNELL, Naturrecht, Vorlesungen . . . . . . . . . . 19

SOCAGE SERVICE ................... 153, 154

SOCIAL CONVENTION (deportment, Anstand) $\ldots \ldots .46,47$

may conflict with law .................. 46

may involve legal consequences $\ldots \ldots \ldots \ldots \ldots \ldots \ldots \ldots, 47$

SOCIAL INSTINCT $\ldots \ldots \ldots \ldots \ldots \ldots \ldots \ldots . \mathbf{8}, \mathbf{9}, 73,93.273$

SOCIAL LAW, is a distinct but unclassified department

SOCIAL REVENGE (Gemeinrache), a basis of criminal $94,95,96$

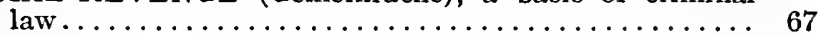


SOCIALISM

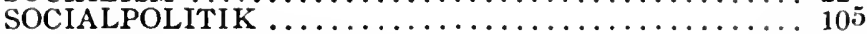

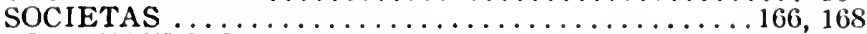

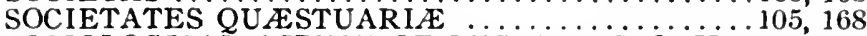

SOCIOLOGICAL ASPECT OF LEGAL H ISTORY ..... 326

SOHM, Institutionen, $13,70,73,81,102,106,108,138,139$, $144,149,155,157,166,180,184,186,187,202,208,211$

SOLLENDEN HANDLUNGEN (acts wanting in legal

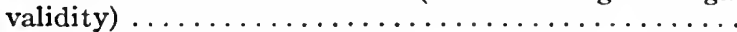

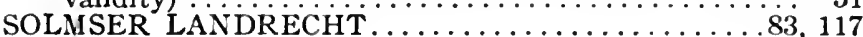

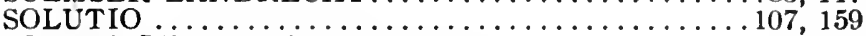

SONDERGUT (privileged property) ........... 194

SONDERNACHFOLGE (particular succession) $\ldots \ldots \ldots 206$

SONDERRECHT (special law) ................. 70

SOURCE OF LAW, is the agency which provides the mate-

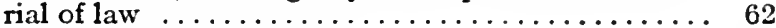

ambiguity of the expression $\ldots \ldots \ldots \ldots \ldots \ldots \ldots \ldots \ldots$

classification......................... 73

in a technical sense is the causa efficiens of the legal

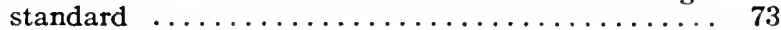

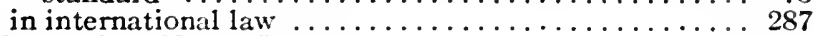

SOVEREIGNTY OF JUSTICE .............

SPECIAL LAW OF PROFESSION AND POSITION $292 f$.

SPENCER, the principles of sociology ........... 8 social statics..................... 19

the man versus the state $\ldots \ldots \ldots \ldots \ldots \ldots \ldots \ldots . \ldots \ldots$

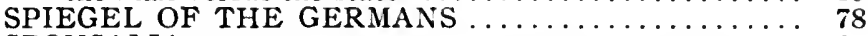

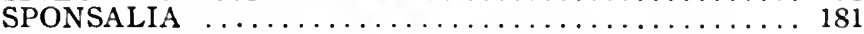

SPURIOUS INTERPRETATION (see interpretation).

STAATENBUND .....................6 60

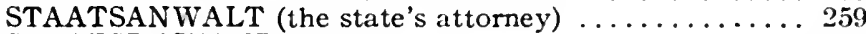

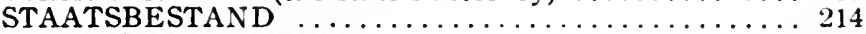

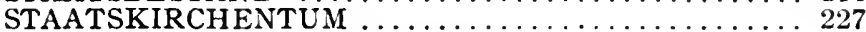

STAATSLEHRE (science of the state) $\ldots \ldots \ldots \ldots \ldots 221$

STAATSRECHT (state law, q. v.).

STAATSWISSENSCHAFT (science of state) $\ldots \ldots \ldots \ldots 21$

STADE, Geschichte des Volkes Israel ...........53, 57

STADTRECHT (local law of a municipality) . . . . . . 70

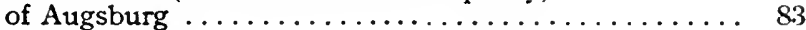

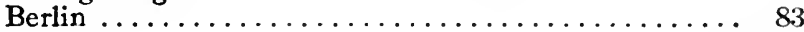

Bremen......................... 117

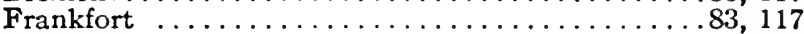

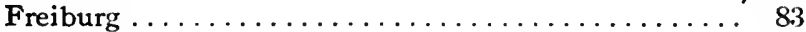

Hamburg ..................... 117

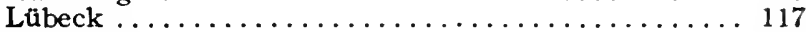

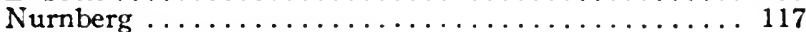

STADTSCREIBER-LITERATUR $\ldots \ldots \ldots \ldots \ldots \ldots \ldots \ldots \ldots \ldots$

STAHL, definition of law $\ldots \ldots \ldots \ldots \ldots \ldots \ldots \ldots \ldots \ldots \ldots$

STAMMES-RECHT $\ldots \ldots \ldots \ldots \ldots \ldots \ldots \ldots \ldots \ldots \ldots \ldots \ldots$

STAMMLER, Wirtschaft und Recht ...........4, 10

das Recht der Schuldverhältnisse . . . . . . . . 10,91

die Behandlung d. röm. Rechts ............ 308

die Gesetzmăssigkeit in Rechtsordnung ......... 10 
STATE LAW

......94, 95, 96, $216 f f$.

STATE SOVEREIGNTY AND STATE INTER

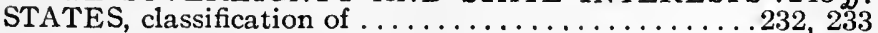

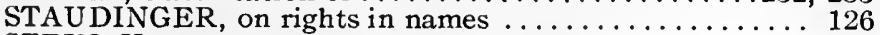

STEIN, Voraussetzungen des Rechtsschutzes .......... 266

das Zivilprozessrecht .................... 267

STENGLEIN, Lehrbuch d. deut. Strafprozessrechts . . . . . 282

STERNBERG, allgemeine Rechtslehre .......... vi, 22 STIFTUNGEN (foundations, q. v.).

STINTZING, Geschichte d. deutschen Rechtswissenschaft,

STIPULATED PENALTIES . . . $\ldots \ldots \ldots \ldots \ldots \ldots \ldots \ldots \ldots . .317,318,319,320,321$

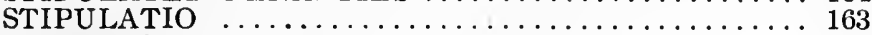

STOBAUS

STOBBE, Geschichte der deutschen Rechtsquellen, $77,8 \ddot{4}$

Handbuch des deutschen Privatrechts, $77,87,90,164,199$ deutsches Privatrecht . ..............138, 145

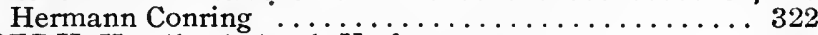

STOERK, Handbuch der $\mathrm{d}$. Verfassungen $\ldots \ldots \ldots \ldots \ldots 220$

international law as law in the true sense . . . . . . 288

STOLZEL, Schulung für zivilistische Praxis. . . . . .88, 269, 326

die Entwickelung des gelehrten Richtertums . . ..268, 281

Carl Gottl. Suarez ...................... 310

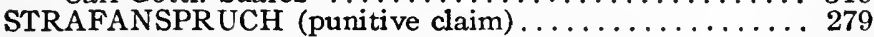

STRANDRECHT (law of stranded things) . . . . . . 146

STREITGENOSSENSCHAFT (joinder of parties) $\ldots \ldots \ldots 267$

STUBBS, constitutional history of England $\ldots \ldots \ldots \ldots 56$

STUDY OF LEGAL SCIENCE, divisions . . . . . . 307

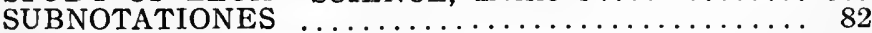

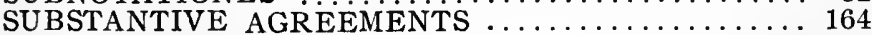

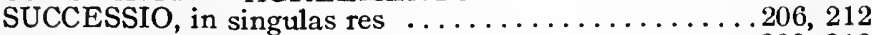

per universum jus . . . . . . . . . . . . . . 206, 212

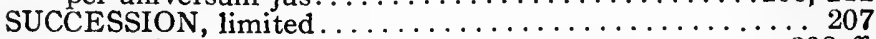

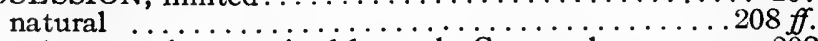

only natural, recognized by early German law ....... 208

particular...................205, 206,212

Roman law permitted natural, only in default of will. 208

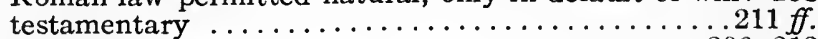

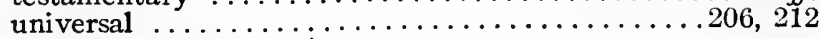

SÜHNE (atonement, q. v.).

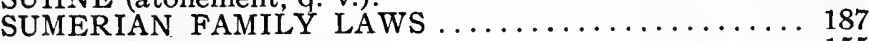

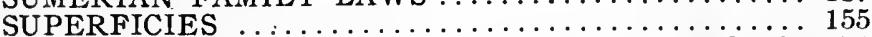

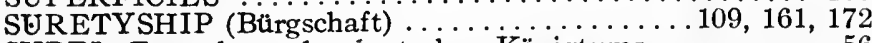

SYBEL, Entstehung des deutschen Königtums .......... 56

SYNTHETIC METHOD OF TREATMENT OF LEGA MATERIALS ...

SYSTEM OF CIVIL LAW AND ITS DEVELOPMENT

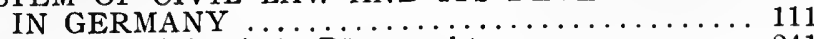

SZANTO, das Griechische Bürgerrecht ........... 241 


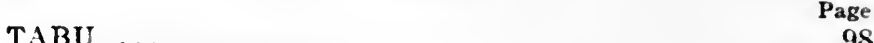

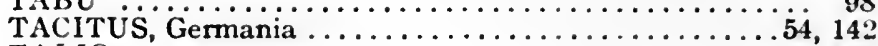

TALIO ............................ 227

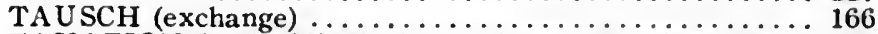

TAXATION, in the Middle Ages belonged to private law . 98

TAYLOR, elements of civil law ............. 19

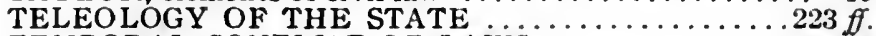

TEMPORAL CONFLICT OF LAWS ..........

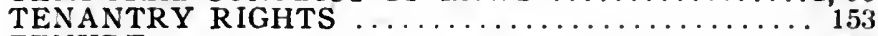

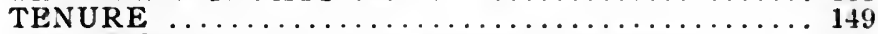

TERRITORIALHOHEIT (territorial sovereignty) ...... 215

TERRITORIAL CONFLICT OF LAWS . . . . . . . 71,90

TERRITORIAL PRINCIPLE OF LAW $\ldots \ldots \ldots \ldots \ldots \ldots, 72$

TERRY, principles of Anglo-American law $\ldots \ldots \ldots \ldots \ldots 26$

TESTAMENTARY SUCCESSION $\ldots \ldots \ldots \ldots \ldots \ldots .211 \mathrm{ff}$.

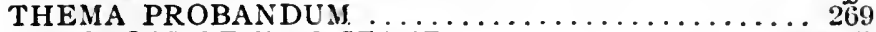

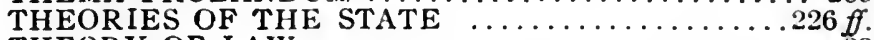

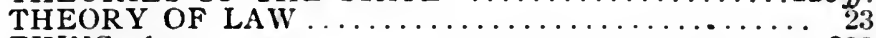

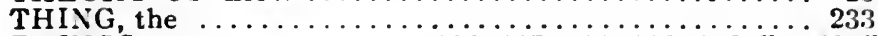

THINGS $\ldots \ldots \ldots \ldots \ldots \ldots \ldots 106,107,111,112,136 f f, 149 f f$ infringements of immaterial $\ldots \ldots \ldots \ldots \ldots \ldots \ldots, 174$ in legal sense are material objects . . . . . . . . 170

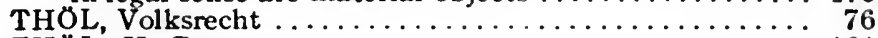

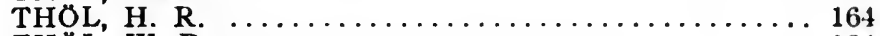

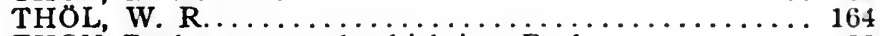

THON, Rechtsnorm und subjektives Recht ......... 33

THUDICHUM, die Gau- und Markverfassung......... 55

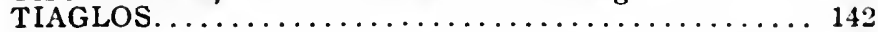

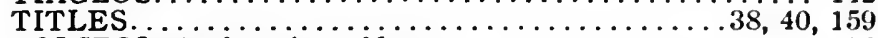

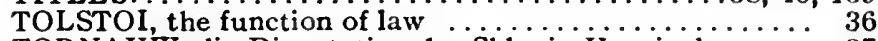

TORNAU $W$, die Disputation der Sklavin Husniyeh ...... 37 das Erbrecht nach den Verordnungen des Islam ...... 37

TOURTOULON, les principes philos. de l'histoire du

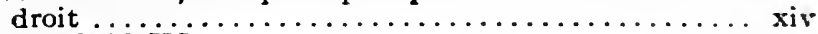

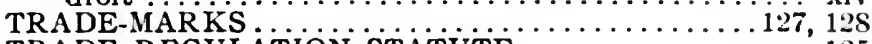

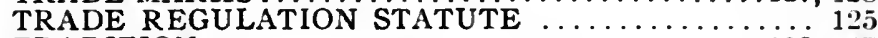

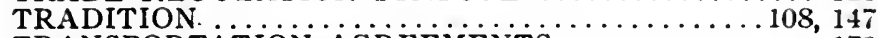

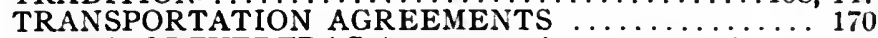

TRANSPORTVERTRAG (transportation agreement) . . . 161

TREASURE-TROVE $\ldots \ldots \ldots \ldots \ldots \ldots \ldots \ldots \ldots \ldots \ldots \ldots \ldots \ldots \ldots$

TREATISES ON GERMIAN CIVIL CODE ............

TRENDELENBURG, Naturrecht auf dem Grunde der

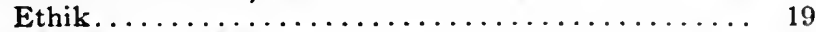

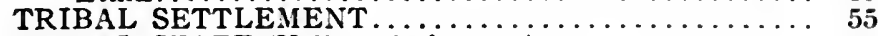

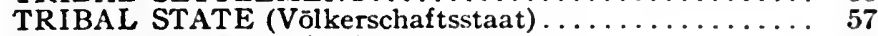

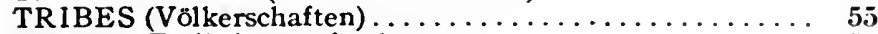

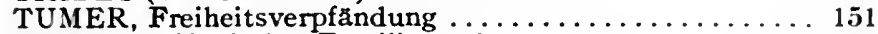

TURNER, Slavisches Familienrecht $\ldots \ldots \ldots \ldots \ldots \ldots \ldots 53$

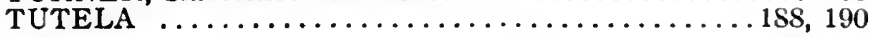

ÜBERTRETUNGEN (lesser offenses) . . . . . . . . 276, 278

ULLMAN, international law . . . . . . . . .

UNCERTIFICATED HYPOTHEK (see pledge rights). 


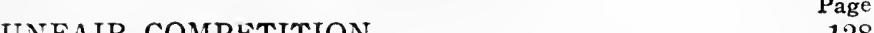

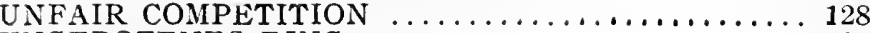

UNGEBOTENES DING $\ldots \ldots \ldots \ldots \ldots \ldots \ldots \ldots \ldots \ldots \ldots$

UNGER, on matrimonial law ................... 2

UNICAMERAL ASSEMBLIES . . . . . . . . . . .

UNIFORMITY OF LEGAL STANDARDS NOT UNI-

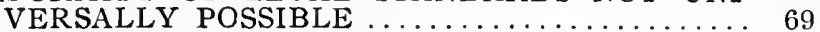

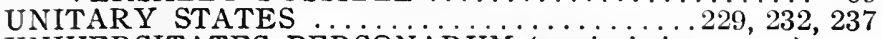

UNIVERSITATES PERSONARUM (see juristic persons).

UNIVERSITATES RERUM (see juristic persons).

UNMITTELBARKEIT (principle of immediacy) . . . . . 268

UNTERSUCHUNGSPRINCIP (inquisitorial principle) . . . 281

UNTERTANEN (feudal dependents, subjects) $\ldots \ldots \ldots \ldots .59$

UNWRITTEN LAW OF GERMANY, authoritative sources 78

UPWARD, the new word $\ldots \ldots \ldots \ldots \ldots \ldots \ldots \ldots \ldots \ldots \ldots$ xii

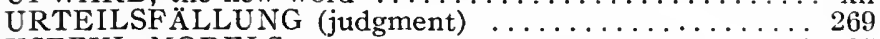

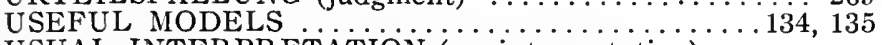

USUAL INTERPRETATION (see interpretation).

USUCAPION (see usucaption).

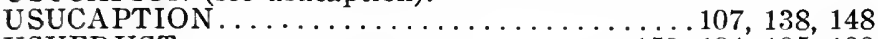

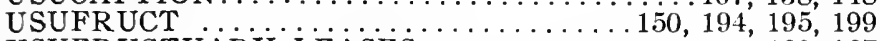

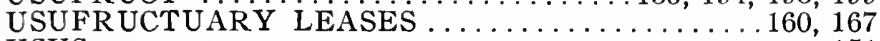

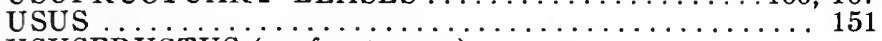

USUSFRÜCTUS (usufruct, q. v.).

USUS MODERNUS PANDECTARUM . . . . . . . 308, 326

VAREILLES-SOMMIERES, principes fond. du droit.... xiv

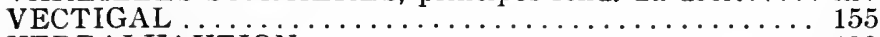

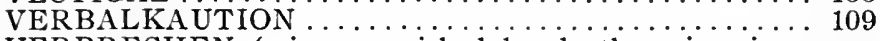

VERBRECHEN (crimes punished by death or imprison-

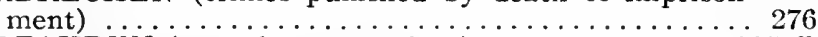

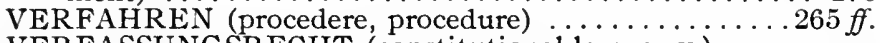

VERFASSUNGSRECHT (constitutional law, q. v.).

VERGEHEN (crimes punished by fine or imprisonment) . . 276

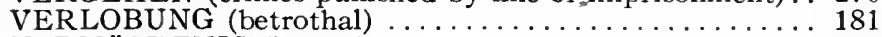

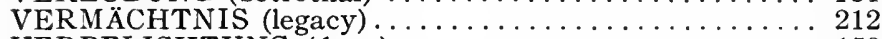

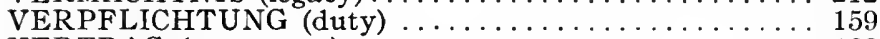

VERTRAG (agreement) $\ldots \ldots \ldots \ldots \ldots \ldots \ldots \ldots \ldots \ldots \ldots 2$

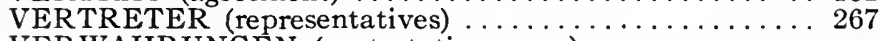

VER WAHRUNGEN (protestation, q. v.).

VERWAHRUNGSVERTRAG (depository agreement) 161,169

VER WALTUNGSGEMEINSCHAFT (administrative com-

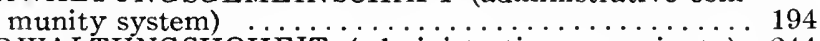

VERWALTUNGSHOHEIT (administrative sovereignty). 244

VER WALTUNGSLEHRE (by Rümelin, et al.) ........ 244

VERWALTUNGSPOLITIK (administrative polity) . . . . . 22

VERWALTUNGSRECH'T (administrative law, q. v.)

VESTITURA ....................... 138

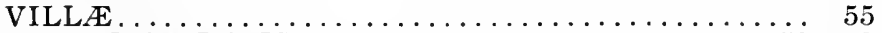

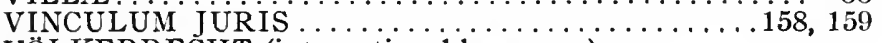

VÖLKERRECHT (international law, q. v.).

VÖLKERSCHAFTEN (tribes, q. v.).

VÖLKERSCHAFTSSTAAT (tribal state, q. v.).

VOLK LAWS. 
VOLKSGERICHTE (popular courts) .................. Page

VOLKSKÖNIG (elective king) $\ldots \ldots \ldots \ldots \ldots \ldots \ldots \ldots \ldots \ldots .5 \ldots \ldots \ldots$

VOLKSKONIGTUM (kingdom with a Volkskönig) $\ldots \ldots .59$

VOLKSSTAAT (people-state, q. v.).

VOLLSTRECKUNGSBEAMTEN (executing officers) . . . 259

VORBEHALTE (reservation, q. v.).

VORBEHALTSGUT (privileged property) . . . . . . . 195

VORKAUFSRECHTE (pre-emption rights) $\ldots \ldots \ldots \ldots \ldots 155$

VORMUNDSCHAFTSGERICHT (guardianship court) $1 \dot{8} \dot{8}, 261$

WACH, Vortråge t. d. R. Z. Pr. O. ............ 267

WÄCHTER, Enzyk. d. Wechselrechts . . . . . . . . 302

WADIUM $\ldots \ldots \ldots \ldots \ldots \ldots \ldots \ldots \ldots \ldots \ldots 1,164,166$

WAGERING AGREEMENTS $\ldots \ldots \ldots \ldots \ldots \ldots \ldots \ldots \ldots$

WÄHLENDE KRITIK (selective criticism, see criticism).

WAITZ, uber die Altgermanische Hufe .......... 55

das alte Recht der salischen Franken ........... 55

deutsche Verfassungsgeschichte ........... 55

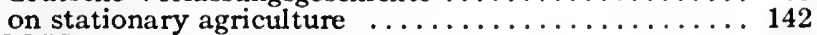

WALLIS, essay on biblical sociology $\ldots \ldots \ldots \ldots \ldots \ldots \ldots, 41$

WANG, translation of German civil code $\ldots \ldots \ldots \ldots \ldots$ xv

WELFARE THEORIES OF THE STATE .......... 223

WERKVERTRAG (agreement for a definite work, see also Dienstvertrag) .................... 170

WERNER, report on the civilization of the South Sea

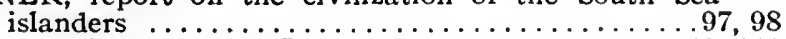
ownership among the Samoans .............. 140, 141

WERTPAPIERE (negotiable instruments of German Law)

$164,172,302$

WIGMORE, on codification $\ldots \ldots \ldots \ldots \ldots \ldots \ldots \ldots \ldots \ldots$

WILLKÜR BRICHT STADTRECHT ........... 90

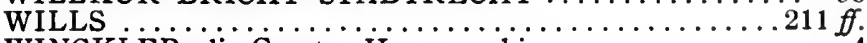

WINCKLER, die Gesetze Hammurabis ............ 4

WINDSCHEID (rectoral address), die Aufgaben der rechtswissenschaft. ...........12,16,17,19,33,37,62

Gesammelte Reden .................... 12

Lehrbuch des Pandektenrechts, $31,33,38,48,76,87$, $89,90,111,155,164,317,319,320$

WIRTSCHAFTSPOLITIK (economic polity) ....... 59

WOODLAND COMMUNITIES $\ldots \ldots \ldots \ldots \ldots \ldots \ldots \ldots 142$

WRITTEN LAW OF GERMANY $\ldots \ldots \ldots \ldots 82,83,84,85$

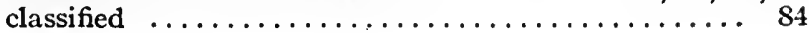

YAJNAVALKYA $\ldots \ldots \ldots \ldots \ldots \ldots \ldots \ldots \ldots \ldots \ldots$

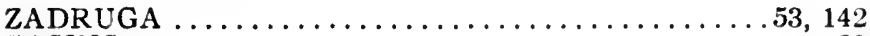

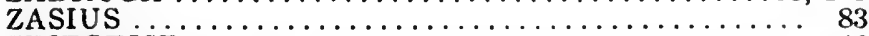

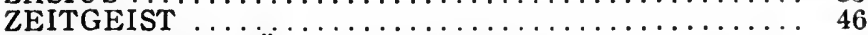

ZEITSCHRIFT FÜR DEUTSCHEN ZIVILPROZESS . . 266

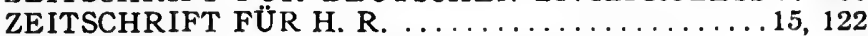

ZEITSCHRIFT f. ÄRZTLICHE FORTBILDUNG . . . . 126

ZEIT.SCHRIFT (Osterr.) FÜR GESETZGEBUNG . . 285, 286 
ZEITSCHRIFT - FÜR VERGLEICHENDE RECHTSWISSENSCHAFT, $2,3,6,14,21,29,36,37,40,43$,

$49,53,67,68,160$ ZEITSCHRIFT (Tübinger) f. d. GES. STAATSWISSENSCHAFT . . . . . . . . . . . . . . . 286 ZEITSCHRIFT FÜR STRAFRECHTSWISSENSCHAFT

$13,15,33,67$
ZELLER, Kom. a. d. allg. bürg. Gesetzbuch . . . . . . . . 309 ZENKER, der Anarchismus ............... 10 ZIVILPROZESS (civil procedure) ….... ZORN, Staatsrecht d. deutschen Reiches ...221, 233, 234, 238 ZUSTELLUNGSBEAMTEN (summoning officers) . . . . 259 ZWANGSRECHT . . . . . . . . . . . . . . . . . . . 251 ZWANGSVOLLSTRECKUNGSVERFAHREN (execution) 269 


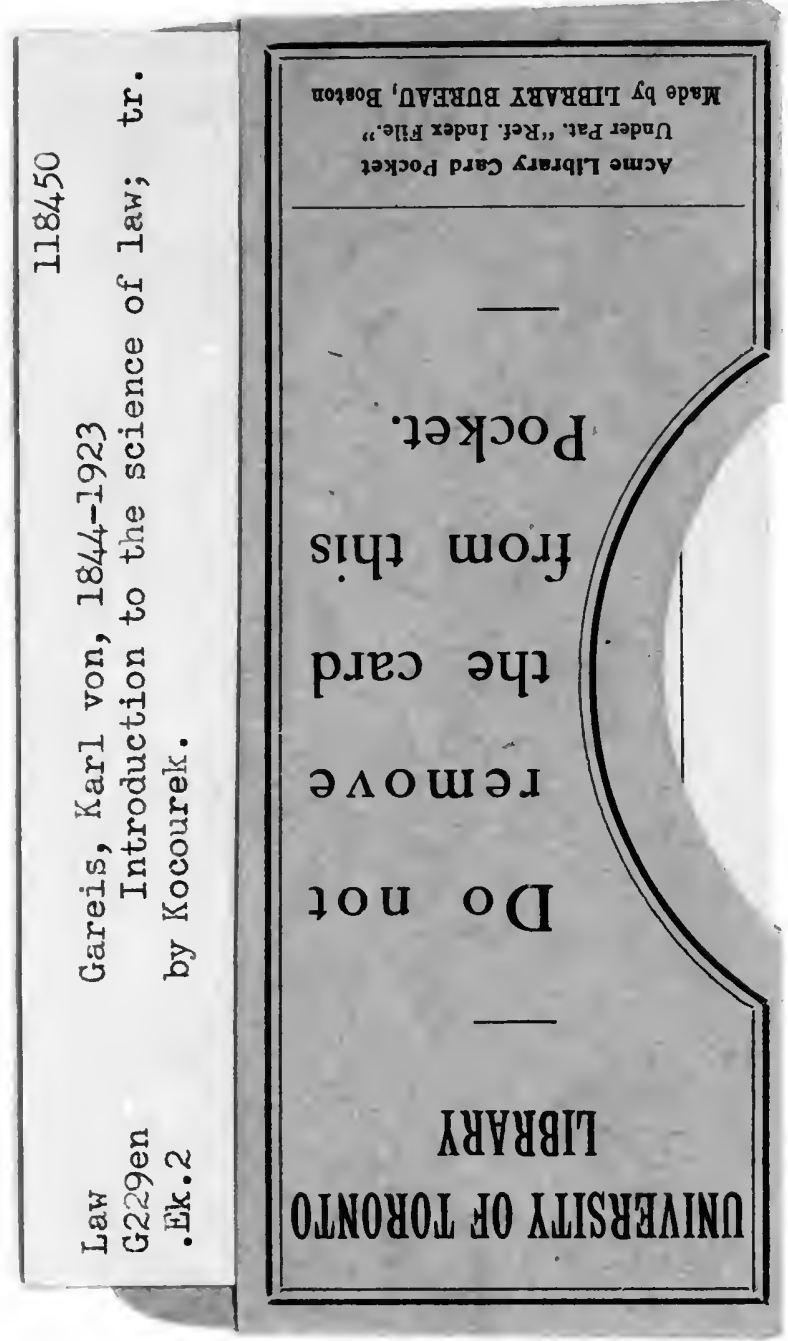


